UNIVERSIDADE DE SÃO PAULO

FACULDADE DE ECONOMIA, ADMINISTRAÇÃO E CONTABILIDADE DEPARTAMENTO DE CONTABILIDADE E ATUÁRIA

ANÁLISE DA RELAÇÃO ENTRE A INFORMAÇÃO CONTÁBIL E O RISCO SISTEMÁTICO

Ana Luísa Gambi Cavallari de Amorim

Orientador: Prof. Dr. Iran Siqueira Lima

SÃO PAULO

2010 
Prof. Dr. João Grandino Rodas

Reitor da Universidade de São Paulo

Prof. Dr. Carlos Roberto Azzoni

Diretor da Faculdade de Economia, Administração e Contabilidade

Prof. Dr. Fábio Frezatti

Chefe do Departamento de Contabilidade e Atuária

Prof. Dr. Edgard Bruno Cornachione Jr

Coordenador do Programa de Pós-Graduação em Ciências Contábeis 


\title{
ANÁLISE DA RELAÇÃO ENTRE A INFORMAÇÃO CONTÁBIL E O RISCO SISTEMÁTICO
}

\begin{abstract}
Tese de Doutorado apresentada ao Departamento de Contabilidade e Atuária da Faculdade de Economia, Administração e Contabilidade da Universidade de São Paulo, como requisito para a obtenção do título de Doutora em Controladoria e Contabilidade.
\end{abstract}

Orientador: Prof. Dr. Iran Siqueira Lima

\section{SÃO PAULO}





\section{FICHA CATALOGRÁFICA}

Elaborada pela Seção de Processamento Técnico do SBD/FEA/USP

Amorim, Ana Luísa Gambi Cavallari de

Análise da relação entre a informação contábil e o risco

sistemático / Ana Luísa Gambi Cavallari de Amorim. -- São

Paulo, 2010.

205p.

Tese (Doutorado) - Universidade de São Paulo, 2010.

Orientador : Iran Siqueira Lima

1.Contabilidade financeira 2. Análise de risco 3. Demonstração financeira 4. Mercado de capitais I. Universidade de São Paulo. Faculdade de Economia, Administração e Contabilidade. II. Título.

CDD - 657.48 
Primeiramente, agradeço ao Senhor Jesus Cristo que é Deus Forte e Maravilhoso Conselheiro. Ao Eduardo Marchesi de Amorim, meu amor, pelo estímulo, impulso e colo, este doutorado também é seu.

Ao Prof. Dr. Iran Siqueira Lima, uma das pessoas mais elegantes de comportamento que conheci, obrigada pelas preciosas contribuições técnicas, estímulo constante, apoio e confiança em mim depositada.

À minha amiga e mãe, Eliana de Lima Gambi, pela dedicação e amor sempre presentes em minha vida e pelo exemplo cotidiano de esforço e otimismo. Ao melhor médico que conheço, meu irmão, Flávio Luiz Gambi Cavallari. Ao meu pai, Marcos José Cavallari, pela constante “corujisse" e bondade para comigo. Aos meus sogros, Álvaro e Weimar, pelo apoio, incentivo e compreensão. Aos familiares, tios, tias e primos e a minha vovó Anna, pela torcida.

Aos meus novos amigos que fiz no doutorado, em particular, Adriana Cristina da Silva, e ao amigo/irmão João Batista Nast Lima, a amizade de vocês foi um ótimo presente para mim.

A uma amiga em especial, Ana Helena Szasz, melhor anfitriã impossível, obrigada por todas as vezes que me recebeu em sua casa, nesses três anos, sempre com alegria e afeto.

A todos os amigos que me apoiaram, incentivaram e oraram, em especial, Daniel Olivieri, Sarita Avila Olivieri, Tatiana Barbosa, Nilce Mica, Mônica Vicenti, Carlos Alberto Grespan Bonacim e Mariana S. F. Amaral Fregonesi, obrigada!

Aos Professores Gerlando Augusto Sampaio Franco de Lima e Marina Mitiyo Yamamoto pela atenção e auxílio na elaboração desta tese.

Ao Prof. Dr. Ariovaldo dos Santos, Prof. Dr. Luiz João Corrar e Prof. Dr. Alexsandro Broedel Lopes, as disciplinas que fiz com o senhores contribuíram abundantemente para minha formação e para a realização do trabalho. Aos profissionais Cristina, Rodolfo, Regina, Prof. Aquino, Cida e Valéria pela ajuda e dedicação.

Aos professores da banca Prof. Dr. Wilson Toshiro Nakamura, Prof. Dr. Antonio Benedito Silva Oliveira e Prof. Dr. Francisco Carlos Fernandez pelas preciosas contribuições ao trabalho.

À CAPES pela bolsa proporcionada no doutorado.

Meu coração é grato! 

"Oh! Provai e vede que o Senhor é bom; bem-aventurado o homem que nele se refugia."

Salmo 34:8 


\section{RESUMO}

A hipótese de mercado eficiente e o CAPM trouxeram o conceito de que a nova informação relevante exerce um efeito imediato sobre o preço de um título, alterando expectativas quanto ao seu risco: beta de mercado. (HENDRIKSEN, VANBREDA, 1999, p. 184). Ao encontro dessa realidade, este trabalho foi desenvolvido para investigar se os betas contábeis de uma empresa possuem relação com seu risco sistemático, calculado por meio do beta de mercado, e se os betas contábeis e os betas de mercado possuem os mesmos componentes, podendo o beta contábil cooperar na estimação do risco de uma empresa. Para a realização do estudo foram selecionadas 97 empresas, da BM\&FBOVESPA, de 15 setores econômicos, entre o $1^{\text {o }}$ trimestre de 1995 e o 3- trimestre de 2009. Foram utilizados 6 diferentes tipos de cálculo para os betas de mercado e 468 variáveis contábeis e os betas contábeis, totalizando 2.808 coeficientes de correlação. Este estudo utilizou como ferramentas estatísticas a Correlação de Pearson, a Análise de Dados em Painel, a Análise de Componentes Principais e a Correlação Canônica. Os resultados indicaram que a relação para a maior parte das versões de betas contábeis foram poucos significativas ou mesmo inexistentes, entretanto, 27 betas contábeis apontaram possuir relação com os betas de mercado. Também, foi possível constatar que alguns betas contábeis podem explicar o beta de mercado e podem fazê-lo de forma antecipada, podendo, ainda, melhorar a previsão do beta de mercado quando associados a betas históricos. Foi observado que alguns betas contábeis possuem fatores comuns e que esses podem estar, correlacionados com os fatores do beta de mercado. Embora o trabalho tenha identificado a existência de relação de significância estatística entre betas de mercado e determinados betas contábeis, não a encontrou para a maioria dos betas contábeis estudados. 



\begin{abstract}
The efficient market hypothesis and CAPM brought the concept of the new relevant information has an immediate effect on the stock price, changing expectations about their risk, market beta (HENDRIKSEN, VANBREDA, 1999, p. 184). According to the reality, this study was conducted to investigate whether the accounting betas have a relationship with its systemic risk, calculated using the market beta, and if market betas and accounting betas have the same components, so beta accounting can cooperate in estimating the risk of a company. To conduct the study were selected 97 companies, of BMF\&BOVESPA, from 15 economic sectors, between the period, 1st quarter of 1995 to the 3rd quarter of 2009. We used 6 different types for market beta and 468 betas and variables accounting, totaling 2808 correlation coefficients. This study used statistical tools such as the Pearson Correlation, Data Analysis Panel, the Principal Components Analysis and Canonical Correlation. The results indicated that the ratio for most versions of accounting betas were few significant or even nonexistent, however, 27 have pointed accounting betas relationship with market betas. Also, it was established that some accounting betas can explain the market beta and can do so in advance, and may also improve market beta prediction. It was noted that some accounting betas are common factors and that these may be correlated with the factors of market beta. Although the research has identified the existence of statistically significant relationship between market betas and some accounting betas, not found a relation for the most accounting betas.
\end{abstract}





\section{SUMÁRIO}

1 INTRODUÇÃ

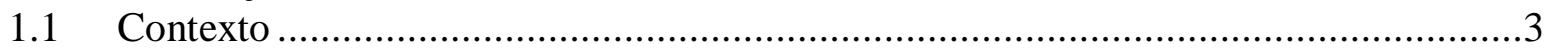

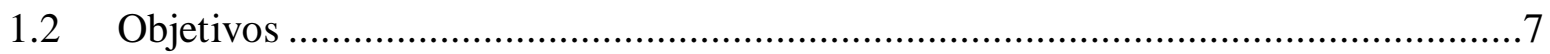

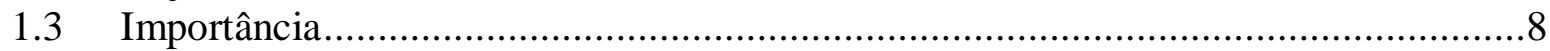

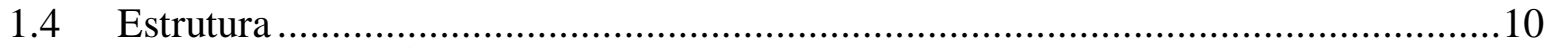

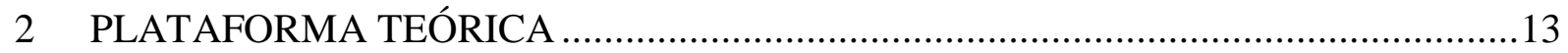

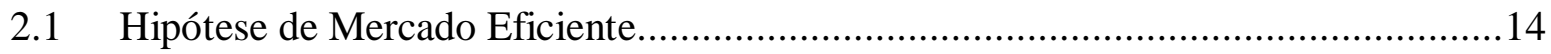

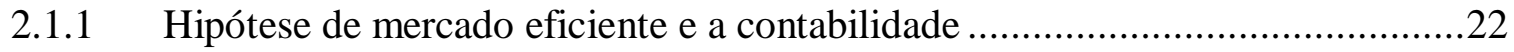

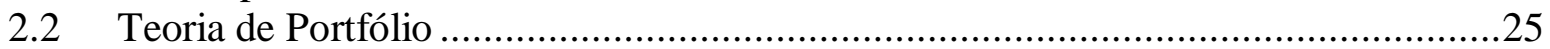

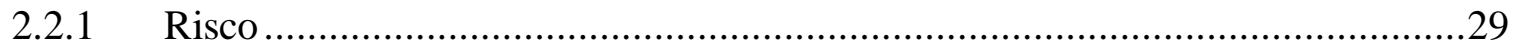

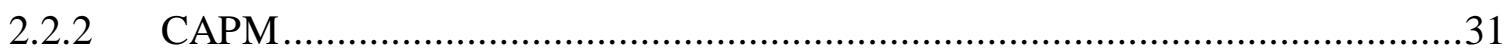

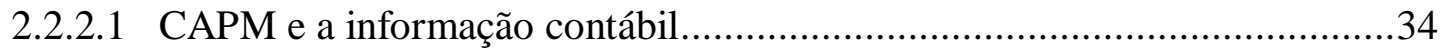

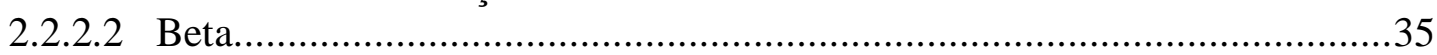

3 PESQUISAS SOBRE A INFORMAÇÃO CONTÁBIL E O MERCADO DE

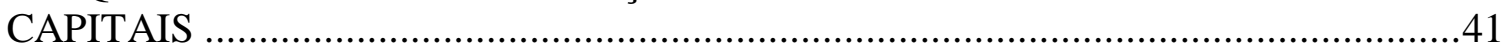

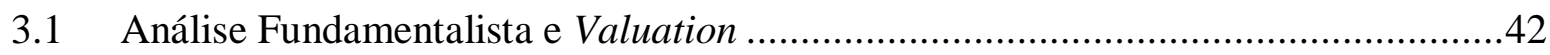

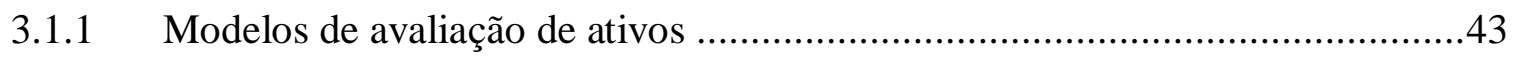

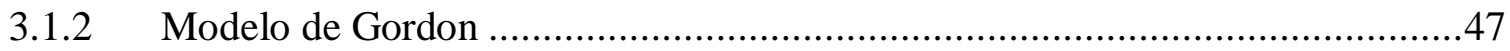

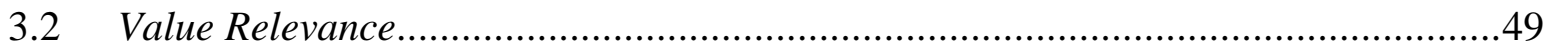

3.3 Estudos sobre Informação Contábil e o Mercado de Capitais ................................51

3.3.1 Estudos sobre análise fundamentalista e value relevance ...............................52

3.3.1.1 Estudos sobre análise fundamentalista e value relevance no Brasil ............55

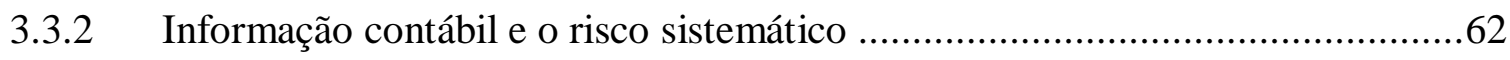

3.3.2.1 Informação contábil e o risco sistemático no Brasil ..................................71

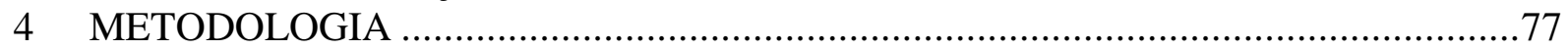

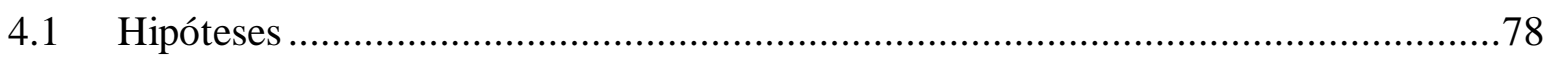

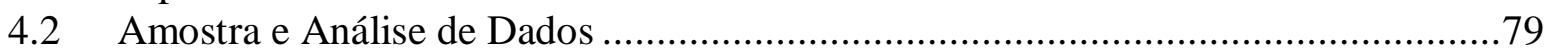

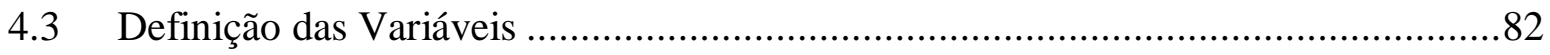

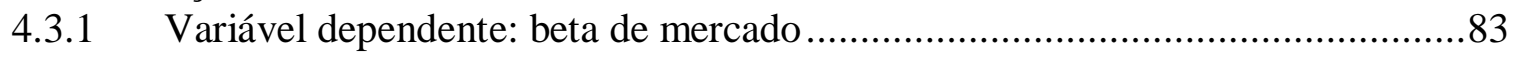

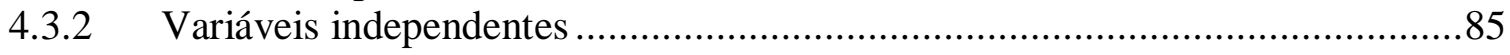

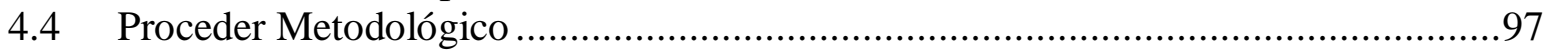

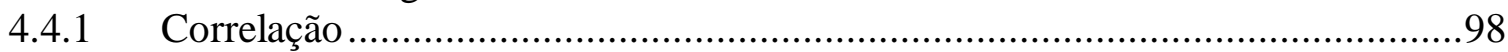

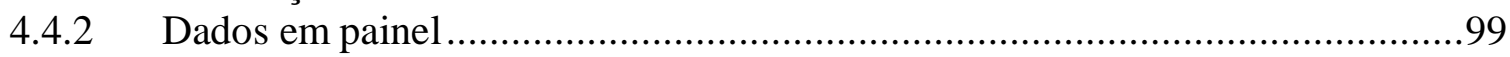

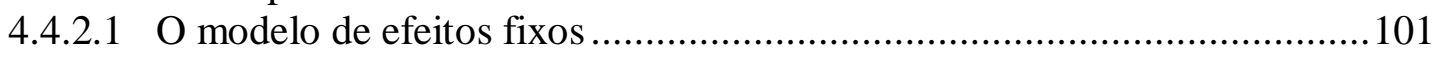

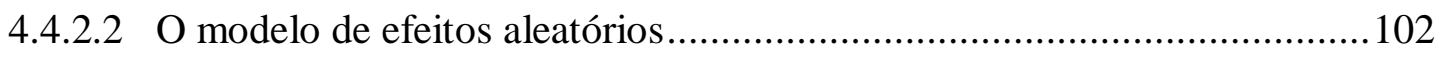

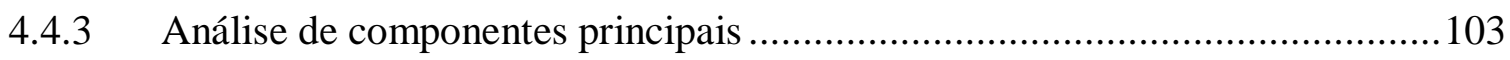

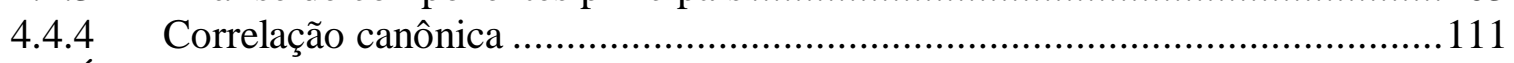

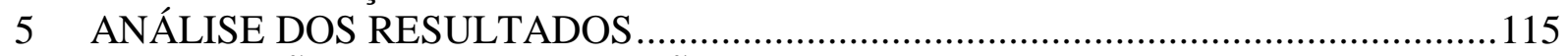

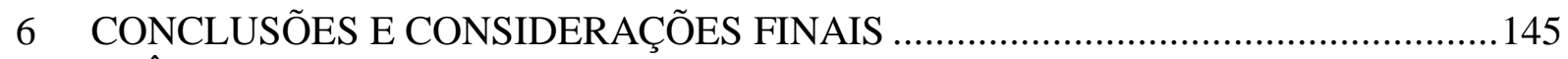

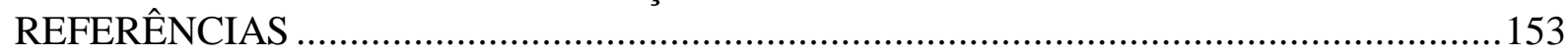

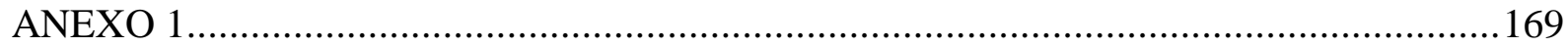





\section{INTRODUÇÃO}

\subsection{Contexto}

Medir o risco de uma empresa é talvez uma das mais procuradas e difíceis tarefas em avaliação de ativos. (NEKRASOV; SHROFF, 2009). Possivelmente, esse seja o motivo desse tema ser alvo de várias discussões tanto no meio acadêmico quanto no ambiente de mercado, principalmente no que se refere à avaliação de investimentos, uma vez que, na definição da taxa de desconto, essa deve embutir o risco da empresa. (FERNANDEZ, 2005).

O risco refere-se à incerteza sobre um evento convertido em um número por mensuração. Está associado à possibilidade de que algum acontecimento desfavorável venha a ocorrer. Contudo, quando o termo risco se refere a investimentos, pode-se associá-lo à probabilidade de, efetivamente, se ganhar menos do que o retorno esperado. (NAKAMURA; MATIAS FILHO, 2006). Por causa disso, os investidores exigem uma taxa para participarem do negócio, a taxa de retorno, e quanto maior o risco associado maior a taxa de retorno exigida. (FERNANDEZ, 2005).

A medida mais consagrada de risco e retorno de um ativo é a proposta por Sharpe (1964) e Lintner (1965) em seu CAPM (Capital Asset Pricing Model), baseado na Teoria de Mercado surgida com Markowitz (1952). Nesse modelo, os autores concluíram que a distribuição dos retornos esperados de todos os ativos de risco é uma função linear do risco dos títulos, isto é, de sua covariância com a variância da carteira de mercado: o coeficiente Beta. O coeficiente beta de uma ação é "uma medida da contribuição de um ativo individual para o risco de um já diversificado portfólio" e corresponde "a sensibilidade do mesmo aos movimentos do mercado.” (BREALEY; MYERS, 2007, p.173).

O beta de mercado foi consagrado pelos investidores como a medida de risco mais observada, correspondendo à parte do risco sistemático que não pode ser diversificada, graduadas pelas características de risco do próprio ativo. Entretanto, essa medida não identifica ou aponta os fatores operacionais e os fundamentos econômicos que influenciam o risco. (RYAN, 1997, p. 88 e GARROD; MRAMOR, 1998, p. 3).

Um dos pressupostos teóricos para este conceito é a Hipótese de Mercado Eficiente. Desenvolvida e apresentada pelo professor da Universidade de Chicago, Eugene Fama, em 
seu trabalho de 1970, publicado no Journal of Finance. Essa hipótese conceituou que os preços refletem, de forma justa, não enviesada e rápida ou, em um tempo muitíssimo pequeno, o conteúdo da informação disponível, de maneira tal que todo o mercado já estará prontamente precificado, tendo sido o conteúdo informacional relevante totalmente absorvido nos preços.

O objetivo da contabilidade vem suprir e contribuir com esse conteúdo informacional. Segundo o FASB (Financial Accounting Standard Board) em seu SFAC1 (Statement of Financial Accounting Concepts, 1978), o objetivo da contabilidade consiste em "[...] prover os usuários dos demonstrativos financeiros informações que o ajudarão a tomar decisões." (IUDÍCIBUS, 2000, p. 20). Nesse contexto, encaixa-se o conceito de Information Approach (abordagem da informação), no qual a contabilidade é considerada como um meio de disponibilizar informações relevantes para os agentes econômicos. (BEAVER, 1998; LOPES, 2002). A contabilidade é, então, uma das fontes de informação para investidores determinarem o preço de uma ação e seu beta de mercado.

Dentre as finalidades principais dos relatórios contábeis, na tomada de decisão, pode ser descrita a capacidade de fornecer acesso aos parâmetros de risco, permitindo revisar ou manter o atual nível de risco de um portfólio. (ILHA et al., 2009). Segundo Hendriksen e Vanbreda (1999, p. 184), a hipótese de mercado eficiente e o CAPM trouxeram o conceito de que a nova informação relevante exerce um efeito imediato sobre o preço de um título, seja alterando expectativas a respeito de seu retorno médio, seja alterando expectativas quanto ao seu beta. Beaver et al. (1970, p. 654) ratificam que "o sistema contábil de uma empresa gera informações que muitos consideram como medidas de risco."

A relação entre retornos dos ativos e as informações contábeis dão-se porque a contabilidade fornece dados passados sobre fluxos de caixa, dividendos, lucros e outros, possibilitando, assim, a estimação de fluxos de caixa futuros com base nessas variáveis. (CARDOSO; MARTINS, 2004). E sendo o valor de um ativo determinado pelo valor presente de seus fluxos de caixa futuros, descontados a uma taxa de risco (ASSAF NETO, 2005, p. 269), as informações contábeis irão impactar no fluxo de caixa futuro sempre que alterarem os possíveis resultados financeiros esperados. Como exemplo, as informações sobre o lucro podem alterar a expectativa de variância de fluxos de caixa futuros, indicando, então, alteração do risco da entidade e do preço da ação. (FERNANDEZ, 2005). 
Dessa forma, uma vez que o risco está diretamente relacionado com a incerteza dos fluxos de caixa, ele acaba sendo afetado por informações contábeis, que impactarem nas projeções desses fluxos de caixa. Com base na relação entre informações contábeis e o preço da ação, Watts e Zimmerman, (1986, p. 118) levantam a suposição de que:

se os lucros contábeis forem aproximadores dos fluxos de caixa, um beta contábil (dado pela covariância entre os lucros da entidade e os lucros do mercado, dividido pela variância dos lucros do mercado) poderia ser também um aproximador do beta da entidade. E é provável que os lucros contábeis possam ser usados para obter estimativas do beta.

Do mesmo modo, Mário e Aquino (2004, p. 211) afirmam que:

Tal questionamento parte do desenvolvimento analítico-teórico, que apresenta a hipótese de os lucros contábeis serem uma estimativa do beta da empresa. Tal hipótese justifica-se devido à taxa de retorno nas ações de uma firma para dado período ser função dos fluxos de caixa realizados para esse período e devido aos lucros contábeis serem uma substituição para os fluxos de caixa, podendo um beta contábil ser um substituto para o beta da empresa.

Beaver et al. (1970, p. 659) concordam que as medidas de risco advindas da contabilidade podem ser vistas como substitutas para a variabilidade total dos fluxos de caixa, pois refletem tanto efeitos conjunturais quanto específicos da empresa. Segundo os autores, o beta contábil pode ser um aproximador do beta de mercado, pois é estimado a partir da covariância entre o retorno contábil de uma empresa e o retorno contábil médio de uma amostra de empresas, divididos pela variância dos retornos dessa amostra.

Assim, a hipótese de não só informações contábeis, mas betas contábeis serem uma estimativa do beta de mercado de uma empresa justifica-se, pois a taxa de retorno das ações de uma firma para um dado período é função dos fluxos de caixa realizados para esse período. Como os lucros contábeis podem representar uma substituição para os fluxos de caixa, o beta contábil poderá ser um substituto para o beta da empresa. (FERNANDEZ, 2005).

A utilidade dos betas contábeis está não só para empresas fechadas, mas também para as firmas listadas cujos betas das ações podem ser estimados usando o modelo de mercado. Já que os números contábeis são capazes de variar com o beta, eles podem ser usados para reduzir o erro de mensuração na avaliação do beta de mercado e fornecer uma melhor estimativa. (WATTS, ZIMMERMAN, 1986, p. 120). 
Os primeiros estudos que buscaram alguma associação entre medidas contábeis e betas de ações foram realizados na década de 70 e encontraram correlações positivas entre as variáveis e os betas contábeis e o beta das ações. Diversos estudos entre os quais Ball e Brown (1969), Ball et al. (1993), Beaver et al. (1970), Beaver e Manegold (1975), Bildersee (1975), Bowman (1979), Brimble e Hodgson (2007), Dechow (1994), Ecker et al. (2009), Elgers (1980), Hamada (1971), Hill e Stone (1980), Ismail e Kim (1989), Karels e Sackley (1993), Laveren et al. (1997), Lev e Kunitzky (1974), Mandelker e Rhee (1984), McAnally et al. (1996), Nekrasov e Shroff (2009), Pettit e Westerfield (1972), Rosenberg e Mckibben (1973) e Thompson (1976) realizaram pesquisas sobre a associação entre variáveis contábeis, algumas delas betas contábeis e betas de mercado. Seus resultados variaram pelo grau de relacionamento entre eles, porém a grande maioria aponta para a existência de certa associação.

No Brasil, estudos como os de Cupertino e Ogliari (2002), Gusmão e Cherobim (2008), Mendonça Neto e Bruni (2004), Minardi et al. (2007), Munhoz (2006) e Ribeiro Neto e Famá (2001) não apresentaram relação entre as variáveis contábeis e betas de mercado. Somente alguns deles, Costa (2007), Fernandez (2005), Ilha et al. (2009), Munhoz (2006), Oda (2004), Rodrigues et al. (2008) e Teixeira e Valle (2008), apontaram uma relação significativa e de certa magnitude entre a variáveis contábeis e o risco sistemático das empresas. A grande maioria não apresentou relação.

De uma forma geral, tanto no Brasil quanto no exterior, os estudos levantados ainda não alcançaram resultados conclusivos. Outro ponto importante, segundo Lopes e Martins (2005), é ainda o número extremamente restrito de estudos sobre esse tema, estando os resultados dos trabalhos de Beaver e outros da década de 70 praticamente inexplorados. Conforme Ryan (1997, p. 83), uma limitação das pesquisas relacionando números contábeis ao risco conjuntural das ações é que a maior parte dos trabalhos foi publicada na década de 70 e 80 e, portanto, emprega modelos do ambiente econômico e dos dados gerados pelo sistema contábil daquela época.

Saber se existe alguma relação entre variáveis e betas contábeis e os betas de mercado pode ser de amplo interesse e atende não apenas aos investidores do mercado de capitais, mas, também, aos gestores das empresas, governos e agências regulatórias, pois, além de atualizar pesquisas anteriores, apresenta um modelo para a estimativa de betas a partir de dados 
contábeis, que pode ser aplicável a diversas situações nas quais não há dados de mercado disponíveis. Além disso, o entendimento dessa relação é importante não somente para uso em casos em que o beta de mercado não está disponível, mas como um complemento e verificador do risco calculado por ele.

Dessa forma, esta tese pretendeu aprofundar a discussão sobre a informação contábil, medida por meio de variáveis e betas contábeis e o risco conjuntural, sistemático das ações de uma empresa: seu beta de mercado. Mais especificamente, busca uma resposta para o seguinte problema de pesquisa:

\section{Os betas contábeis possuem relação com os betas de mercado das empresas?}

\section{$1.2 \quad$ Objetivos}

O objetivo principal desta pesquisa é identificar se os betas contábeis de uma empresa possuem relação com seu risco sistemático, calculado por meio do beta de mercado, para as ações negociadas na BM\&FBOVESPA. Comprovando, assim, que a informação contábil exerce seu papel, é importante para o usuário investidor e pode contribuir na estimação do risco de uma empresa.

A informação contábil cumpre seu papel ao prover aos usuários das demonstrações contábeis informações que os ajudarão na tomada de decisões, fornecendo acesso aos parâmetros de risco e permitindo revisar ou manter o atual nível de risco de um portfólio. (ILHA et al., 2009). São importantes para os investidores à medida que exercem relação com o preço de um título, seja alterando expectativas a respeito do retorno médio, seja alterando expectativas quanto ao seu beta. (HENDRIKSEN; VAN BREDA, 1992; IUDÍCIBUS, 2000). A informação contábil contribuirá na estimação do risco de uma empresa sempre que puder explicar e prever o risco sistemático de um ativo, seja de forma direta ou complementar. Para alcançar o objetivo geral foram realizados os seguintes objetivos específicos:

1) Verificar se os betas contábeis possuem associação com os betas de mercado;

2) Avaliar se os betas contábeis podem explicar os betas de mercado;

3) Constatar se os betas contábeis podem antecipar os betas de mercado; 
4) Analisar se os betas contábeis podem contribuir para a previsão de betas de mercado;

5) Averiguar se betas contábeis e betas de mercado possuem componente comum e

6) Constatar se esses componentes comuns podem estar correlacionados canonicamente.

O trabalho procurou verificar se os betas contábeis e betas de mercado possuem componentes comuns podendo o beta contábil cooperar na estimação do risco de uma empresa. Caso os betas contábeis e de mercado possuam componentes comuns e esses componentes comuns sejam correlacionados (mediante correlação canônica), poder-se-á entender que esse componente é semelhante de acordo com Ball et al. (2009) e Connor e Korajczyk (1987). Se os componentes de betas contábeis e betas de mercado estiverem correlacionados poderá trazer indícios de que os betas possuem partes semelhantes e que o beta contábil poderia ser indicado como um substituto do beta de mercado.

\subsection{Importância}

Primeiramente, os resultados deste trabalho podem contribuir para revelar se as informações contábeis são importantes para o mercado e possuem, assim, conteúdo informacional, demonstrando, também, se o mercado brasileiro pode ser eficiente, em sua forma semiforte, para o conjunto de informações contábeis disponíveis. Pode trazer pistas de que a informação contábil cumpre seu papel, é importante para o usuário investidor, podendo o beta contábil cooperar na estimação do risco de uma empresa. Este estudo colabora com aqueles que unem as informações contábeis ao risco das empresas, estimulando pesquisas dessa relação.

Esta tese pode cooperar com a teoria de cálculo de risco. A Teoria das Carteiras calcula o risco por meio de seu componente sistêmico, uma vez que a parte diversificável pode ser excluída pela diversificação. Se betas contábeis possuírem comprovadamente uma relação com betas de mercado, também poderão ser usados para o cálculo do risco e da taxa de remuneração exigida. Ainda, se existir essa relação, possibilitará outros questionamentos de que o beta contábil poderia ser usado como substituto do cálculo do risco beta. Somado a isso, os betas contábeis podem adicionar informações aos modelos financeiros de risco, como o CAPM, pois identificam fatores operacionais e fundamentos econômicos que influenciam o risco. Este trabalho é importante pois procura adicionar conhecimento em: 
- $\quad$ sugestão de novos cálculos para o beta de uma empresa;

- $\quad$ desenvolvimento de medidas mais eficientes ex post de risco;

- $\quad$ redução do foco do cálculo de risco somente para dados passados de retorno das ações;

- melhorias para o desenvolvimento de estratégias para a construção de riscos de portfólios;

- melhorias dos modelos preditivos de risco conjuntural.

Outro ponto é que este estudo tenta agregar informações para os modelos de avaliação. Se a relação entre as variáveis e os betas contábeis e de mercado é baixa, então, o modelo de avaliação que utiliza esses números contábeis não terá nível de significância considerado e não capturará a informação realmente ocorrida no mercado. Como consequência, os modelos de avaliação e projeções terão baixa exatidão nesse mercado. Além disso, as estimativas de betas contábeis possibilitam uso prático nas situações em que não existam dados de mercado. Como exemplos, citam-se: a possibilidade de determinação do custo de capital para empresas de capital fechado; ofertas públicas iniciais; orçamento de capital para divisões e privatizações.

Este estudo pretende fornecer informações para normatizadores e contadores. É importante para aqueles que processam as informações contábeis, pois o objetivo principal da contabilidade é produzir conteúdo informacional, sabendo que os números contábeis serão usados como elementos de avaliação. É importante para normatizadores de regulação contábil, pois tenta colaborar com o entendimento de quais variáveis são as que mais se associam com o risco da empresa e o impacto de uma mudança ou inclusão de norma.

Por fim, os resultados deste estudo poderão contribuir diretamente para qualquer investidor nacional ou estrangeiro. De acordo com Damodaran (2005), a busca do valor justo de um ativo é o conceito perseguido por todo investidor. Saber qual é seu risco, quais variáveis são as que mais se associam a ele, o que o afeta e de que maneira o afeta, é uma informação primordial para o gestor de carteiras.

Diferentemente de outros estudos, que relacionam variáveis contábeis com o retorno das ações, este foca a análise da relação existente entre as variáveis contábeis de betas contábeis e o risco sistemático do beta de mercado. Além disso, procura inovar ao utilizar 6 tipos de betas 
de mercado, 15 variáveis contábeis para a formação de betas contábeis, sendo algumas delas ainda não utilizadas em estudos anteriores no Brasil, como o capital de giro e o múltiplo Market to Book. Para cada uma das variáveis contábeis, estipularam-se 36 versões, calculando ao todo 468 variáveis independentes, o que totalizou 2.808 coeficientes de correlação.

Também introduz novidades ao trabalhar com ferramentas estatísticas ainda pouco ou não utilizadas em estudos anteriores, como: Análise de Componentes Principais e Correlação Canônica.

Enfim, esta tese pretendeu cooperar com o mercado de capitais brasileiro, verificando se existe alguma relação entre os betas contábeis e os betas de mercado da empresa, contribuindo diretamente com a pesquisa contábil, cálculos de risco, modelos de avaliação, normatização contábil e para qualquer investidor nacional ou estrangeiro.

\section{$1.4 \quad$ Estrutura}

O desenvolvimento do trabalho tem a seguinte organização: no capítulo 1, apresenta-se a introdução, o problema da pesquisa, sua definição, objetivos, argumentos sobre a importância do estudo e a forma como está organizado o texto; no segundo, encontra-se a apresentação da plataforma teórica em que se fundamenta esta tese; no terceiro, apresentam-se os principais estudos levantados sobre a informação contábil e o mercado de capitais e sobre as variáveis contábeis e os betas contábeis e o risco sistemático (beta de mercado), no exterior e no Brasil; no quarto, encontra-se a metodologia para a realização do estudo, as hipóteses metodológicas, bem como a conceituação das ferramentas estatísticas de Análise de Correlação, Análise de Dados em Painel, Componentes Principais e Correlação Canônica. São expostas as fontes dos dados, horizonte considerado e critérios de amostragem; no quinto, são descritos os resultados obtidos ante as hipóteses verificadas e suas interpretações, considerando os fundamentos teóricos envolvidos e estudos anteriores; no sexto, foi exposto um resumo da pesquisa, suas conclusões e considerações relevantes. Nesse capítulo, ainda, são sugeridas algumas linhas de pesquisa que poderiam dar continuidade ao trabalho e, por fim, as referências utilizadas. 



\section{PLATAFORMA TEÓRICA}

Uma teoria pode ser definida como um conjunto de conhecimentos organizados que podem ser utilizados para explicar e predizer a ocorrência de determinados fenômenos (HENDRIKSEN; VAN BREDA, 1999; IUDÍCIBUS; LOPES, 2004; SANTOS, 2008). Quando se fala da Teoria Contábil, depara-se com o fato de ela possuir diversos enfoques. Isso faz com que não se tenha um único paradigma de aceitação universal capaz de dirigir o estudo dos fenômenos situados nesse ramo de conhecimento. (HENDRIKSEN; VAN BREDA, 1999).

O que se percebe é o desenvolvimento de duas correntes metodológicas principais: a normativa e a positiva. A metodologia normativa atém-se à análise de normas e prescrição de melhores práticas para a contabilidade. Já a metodologia positiva, também chamada de descritiva, tem feito com que a Teoria da Contabilidade se aproxime cada vez mais do papel explicativo e, tanto quanto possível, também do preditivo. (IUDÍCIBUS; LOPES, 2004). Lopes e Martins (2005) explicam que "nas proposições normativas procura-se o ideal, enquanto nas discussões positivas discute-se o que realmente acaba acontecendo com os agentes econômicos." A Teoria Positiva tem um compromisso de se estudar o que ocorre na realidade, fugindo dos fins normativos.

As hipóteses tomam a forma "If A then B" e são refutáveis. (GOMES; LORIATO, 2006). A Teoria Positiva procura, ao testar empiricamente determinadas hipóteses, permitir o estabelecimento de supostos padrões de comportamento das variáveis estudadas, propiciando, dessa forma, a compreensão da ocorrência dos fenômenos contábeis e a possibilidade de predizê-los. (SANTOS, 2008).

Assim, a Teoria Positiva é concebida com as proposições de interesse voltadas para explicar e predizer realidade. Ela opera com o objetivo de fornecer subsídios para se compreender por que a contabilidade assume esse ou aquele perfil, sem contudo, fazer julgamentos quanto à validade de seus mecanismos operativos. (IUDÍCIBUS; LOPES, 2004)

Essa teoria foi um ramo dos desenvolvimentos teóricos da década de 50, que lançaram a base para a "moderna teoria financeira", como a Teoria de Portfólios de Markowitz (1952), apoiados em outras áreas do conhecimento, sobretudo, na Economia e Estatística. 
(IUDÍCIBUS; LOPES, 2004; LOPES; MARTINS, 2005). Esses conceitos e técnicas puderam expandir os horizontes da contabilidade, conferindo uma maior compreensibilidade acerca dos eventos que ocorrem no mundo real, principalmente aqueles afetados pela informação contábil, fundamentando-se na Teoria de Agência, Teoria dos Contratos, Hipótese de Mercado eficiente e reação do Mercado de Capitais à informação contábil. (IUDÍCIBUS; LOPES, 2004).

Muitos modelos foram desenvolvidos e ferramentas econométricas e estatísticas foram utilizadas sob os conceitos de hipóteses positivas. Essas foram testadas empiricamente com o objetivo de verificar se a teoria condiz com a realidade. (WATTS; ZIMMERMAN, 1986). Os primeiros a incorporarem esses desenvolvimentos foram Friedman (1953); Ball e Brown (1968) e Beaver (1968) e, a partir de então, a Teoria Positiva tornou-se um dos temas mais correntes na Teoria Contábil Internacional, possuindo, hoje, posição de destaque. Nesse contexto, encaixa-se o conceito de Information Approach (abordagem da informação), no qual a contabilidade é considerada como um meio de disponibilizar informações relevantes para os agentes econômicos. (BEAVER, 1998; LOPES, 2002). Dessa forma, os dados emanados da contabilidade, como o Patrimônio Líquido e o Resultado (Lucro ou Prejuízo), devem possuir capacidade informacional. (SARLO NETO et al., 2004).

Esses trabalhos assumiram grande importância para o desenvolvimento da metodologia positiva e estão embasados em dois estudos da Teoria Econômico-Financeira: a Hipótese de Mercado Eficiente (Eficient Market Hypothesys, EMH) e o Modelo de Precificação de Ativos Financeiros (Capital Asset Pricing Model, CAPM), que serão mais bem detalhados nos próximos tópicos 2.1 e 2.2 com suas ligações com a contabilidade.

\subsection{Hipótese de Mercado Eficiente}

A Hipótese de Mercado Eficiente (EMH), desenvolvida e apresentada pelo professor da Universidade de Chicago, Eugene Fama, em seu trabalho de 1970, publicado no Journal of Finance, possibilitou avanço significativo nas pesquisas empíricas de finanças com relação ao Mercado de Capitais. (IUDÍCIBUS; LOPES, 2004). 
A Hipótese de Mercado Eficiente é uma extensão do equilíbrio de mercado. O equilíbrio de mercado é a Teoria Financeira que defende que no mercado de concorrência perfeita, a lei da oferta e da procura implica que os preços de mercado atinjam um preço de equilíbrio e esse implica que os lucros econômicos tendam a zero ao longo do tempo. (IUDÍCIBUS; LOPES, 2004; ROBERTS, 1967). Por este conceito, uma vantagem comparativa para um investidor só é possível pela posse de diferentes informações que não estejam completamente refletidas nos preços das ações, pois, se um mercado é eficiente, as ações estão sempre em equilíbrio e, portanto, não é possível para um investidor "superar o mercado", ou seja, obter retornos adicionais a outros investidores. (CERETTA, 2001a; WESTON; BRIGHAM, 2000).

Hendriksen e Van Breda (1999) completam que isso é feito de forma não viesada. Beaver (1998) detalha que o mercado é eficiente, com relação a um sistema de informações, se, e somente se, os preços dos títulos forem os mesmos que seriam em uma economia idêntica em que todo indivíduo tivesse o mesmo acesso ao sistema de informação. Para Brealey, Myers e Marcus (2002), a definição vai ainda mais além, se mercados de capitais forem eficientes, todos os títulos serão justamente precificados à luz das informações disponíveis aos investidores. Dessa forma, em um mercado eficiente os preços sempre refletem prontamente a informação disponível.

Sobre o conjunto de informações, Jensen (1978) chama a atenção para o fato de que um mercado é eficiente, relativamente a um conjunto de informações no $\theta_{t}$, se for impossível obter lucro econômico, lucro anormal zero, mediante negociações com base em tais informações.

Dessa forma, segundo os autores acima, o conceito de eficiência de mercado consiste em que os preços reflitam, de forma justa, não enviesada e rápida, ou em um tempo muitíssimo pequeno, o conteúdo da informação, de maneira tal que todo o mercado já estará prontamente precificado, tendo sido relevante o conteúdo informacional totalmente absorvido nos preços, não sendo possível obter retornos acima do esperado ao longo do tempo.

Para que isso ocorra (o mercado seja eficiente e reflita totalmente a informação), Iudícibus e Lopes (2004, p. 73 e 74), baseados em Beaver (1998, p.125-129) e Fama (1970, p. 387), Hendriksen e Van Breda (1992, p. 169), Watts e Zimmerman (1986, p. 17 e 19), apontam algumas condições: 
[...] que nele não existam custos de transação nas negociações ocorridas no mercado de capitais; que toda a informação nele disponível seja acessível a todos os participantes do mercado por preços irrisórios ou sem custo; e que todos os participantes do mercado possuam expectativas homogêneas em relação aos efeitos das informações disponíveis nos preços do ativo.

Damodaran (2005) define um mercado eficiente como aquele em que o preço de mercado é uma estimativa não tendenciosa do valor real do investimento e ressalta a compreensão de alguns conceitos intrínsecos a esta definição:

- $\quad$ A eficiência de mercado não define que o preço de mercado seja igual ao valor real do investimento a todo momento. Os preços podem desviar do valor real, para mais ou para menos desde que esses desvios sejam aleatórios;

- $\quad$ Os desvios aleatórios implicam que exista igual probabilidade de que uma ação seja sub ou supervalorizada em qualquer momento e tais desvios não sejam correlacionados com outras variáveis aleatórias;

- Sendo os desvios em relação aos valores reais aleatórios, nenhum grupo de investidores deveria ser capaz de encontrar ações sub ou supervalorizadas utilizando qualquer estratégia de investimento.

Segundo Iudícibus e Lopes (2004, p. 81 a 84):

"de forma geral, o retorno de equilíbrio de um ativo, condicionado a um conjunto de informações relevantes, é função do seu risco e pode ser expresso da seguinte forma,

$$
E\left(p_{i, t+1}\left|\phi_{t}\right|\right)=\left[1+E\left(r_{i, t+1}+1\left|\phi_{t}\right|\right)\right] p_{i, t}
$$

em que: $p_{i, t}$ é o preço do ativo i na data $\mathrm{t} ; p_{i, t+1}$ é o preço do ativo i na data futura $t+1 ; r_{i, t+1}$ é a expectativa de retorno futuro do ativo i dado seu risco; $\phi_{t}$ é o conjunto de informações disponíveis na data t. O retorno futuro do ativo i é dado por:

$$
r_{i, t+1}=\frac{p_{i, t+1}+d_{i, t}-p_{i, t}}{p_{i, t}}
$$

em que: $d_{i, t}$ são os dividendos pagos pelo título i durante o período t. Assim, o preço esperado de um título para o período $t+1$, condicionado às informações existentes em $t$, é igual ao preço corrente (em $t$ ) multiplicado pelo retorno esperado do título no período $t+1$, já incorporadas as informações disponíveis em t. Se o título for negociado com base no conjunto de informações $\phi_{t}$, o lucro da negociação de um título em t+1 será:

$$
x_{i, t+1}=p_{i, t+1}-E\left(p_{i, t+1}\left|\phi_{t}\right|\right)
$$

O lucro obtido em $\mathrm{t}$ com a negociação do título i, $x_{i, t+1}$ é igual ao preço corrente menos o que se esperava que fosse o preço do título com base no conjunto de informações $\phi_{t}$. Na EMH, espera-se que esse retorno seja zero, pois a informação já teria sido absorvida no preço do título em t; logo, o preço após a negociação seria igual ao preço esperado do título, nesse conjunto de informações $\phi_{t}$. Portanto, o lucro anormal tende a zero: 


$$
E\left(p_{i, t+1}\left|\phi_{t}\right|\right)=0
$$

Dessa forma, em um mercado eficiente a média dos retornos anormais, ao longo do tempo, é zero. O conceito de retorno anormal está na diferença entre o retorno realizado (t) e o retorno esperado $E\left(p_{i, t+1}\left|\phi_{t}\right|\right)$, a esperança dos retornos calculada com base em observações passadas. Se o mercado for eficiente em relação a um conjunto de informações, determinado investidor poderá, por questão de sorte, apurar um lucro acima do mercado em certa transação efetuada em determinado período, porém não é razoável esperar que ele tenha sorte sempre, pois, ao longo de $n$ transações, efetuadas no decorrer de um período $\left(\mathrm{t}_{\mathrm{n}}, \mathrm{t}_{\mathrm{n}+1}\right)$, aquele investidor vai apurar o mesmo lucro que o mercado, portanto não será um lucro anormal”.

Com o objetivo de analisar a teoria ante a realidade, Hendriksen e Van Breda (1992 p. 171174) esclarecem que um mercado é considerado eficiente em relação a um determinado conjunto de informações; entretanto, existem diversas formas de informações e tempos de precificação dessas informações:

1. Informações obtidas pela observação dos preços de mercado, preços passados;

2. Todas as informações disponíveis para o mercado;

3. Informações privilegiadas, que podem ser adquiridas somente por alguns participantes do mercado.

Com base nestes pontos Fama (1991) divide os estudos em eficiência de mercado em:

- Testes sobre a previsibilidade de retornos - Segundo Fama (1991) antigamente estes testes centravam-se apenas em testar a previsibilidade de retorno de curto prazo com os lucros passados. Agora, não só retornos são testados como múltiplos de dividendos (D / P), lucros (E / P), e mesmo múltiplos e estruturas a termo, em horizontes mais longos. Os testes passaram a ser feitos não só utilizando séries temporais mas utilizando análise de dados em painel. Fama (1991) aponta que quanto a previsibilidade dos retornos ainda não foi encontrado um modelo de preços. Existem apenas vários modelos multi-fatores. Aponta por fim que é possível que todos os modelos estejam capturando o mesmo fator de risco, mas que ainda não foi identificado por nenhum deles.

- Estudos de Eventos - Inúmeros estudos de eventos sobre a eficiência de mercado já foram realizados em muitos tópicos e forneceram a melhor evidência de que o mercado incorpora novas informações muito rapidamente e, geralmente, corretamente. Existem alguns estudos mostrando exceções (por exemplo Ball e o tempo que leva para o mercado a incorporar TODAS as informações de ganhar surpresas.) Fama (1991) 
- Teste de informação privilegiada - Segundo Fama (1991) existem alguns testes diferentes que testam a existência de operações com informações privilegiadas no mercado. São exemplos deles:

- Insider trading agentes com informações internas e privilegiadas superam o Mercado Jaffe (1974) and Seyjun (1986);

- Analistas: Linha de valor e outras anomalias sugerem que analistas possuem alguma informação diferenciada do restante do mercado. Isto não está de acordo com a eficiência de Mercado porém corrobora com os custos de informação (Grossman, Stiglitz, 1980);

- Administradores de carteiras: Parte do pressuposto de que um grupo de analistas não pode superar o mercado.

Com base nessas categorias de informações a EMH é desdobrada em três formas (FAMA, 1976):

1- Forma fraca da EMH: O conjunto de informações é composto somente pelo histórico de preços e os preços correntes refletem completamente as informações contidas nos preços e retornos passados. O comportamento dos preços, por sua vez, é uma função aleatória (random walk) e as informações em preços passados não contêm nenhuma informação sobre preços futuros. (FAMA, 1991; ROSS, 1995; IUDÍCIBUS; LOPES, 2004). As explicações dessa forma de eficiência de mercado implicam uma representação matemática:

$$
\mathrm{P}_{\text {it }}=\mathrm{P}_{\text {it }-1}+\mathrm{E}\left(\mathrm{P}_{\mathrm{it}}\right)-\varepsilon
$$

ou seja, $\mathrm{P}_{\text {it }}$, preço corrente do título é igual ao último preço passado observado $\mathrm{P}_{\text {it-1 }}$ somado ao retorno esperado do título e um erro aleatório, sendo que $\mathrm{P}$ it-1 pode ser observado em qualquer momento anterior a t, um dia, uma hora, um segundo, um ano. Essa é a forma de eficiência de mercado menos exigente, devido à facilidade de acesso as séries históricas dos preços das ações e se fosse possível a obtenção de retornos adicionais por meio da simples indicação de padrões de comportamento dos preços, todos o fariam e qualquer lucro desapareceria na luta para obtê-los. 
2- Forma Semiforte da EMH: situa-se entre a forma fraca e forte, a forma semiforte. Nela, o conjunto de informações contém toda informação publicamente disponível na data t. Os preços correntes dos títulos se comportam como se todos os seus agentes conhecessem as informações publicamente disponíveis e soubessem precificá-las de maneira homogênea. Esse conjunto de informações inclui preços passados, preços correntes, informações contábeis e informações não contábeis entre outras, mas exclui informações privilegiadas. (FAMA, 1991; IUDÍCIBUS; LOPES, 2004). Estudos de eficiência semiforte buscam verificar os ajustes dos preços das ações para determinado tipo de evento gerador da informação. Damodaran (2005) faz algumas ressalvas à forma semiforte, salientando que os preços podem se comportar de três formas diferentes quanto à ocorrência de uma nova informação:

○ os preços podem reagir imediatamente à ocorrência de um evento, de forma adequada, corroborando, assim, a hipótese de eficiência de mercado semiforte;

- os preços podem reagir de forma lenta, apresentando aumento gradual. Esse tipo de reação permite que investidores obtenham retornos anormais com o desvio de preços;

○ ou os preços podem reagir de forma exagerada à divulgação da informação relevante e são corrigidos. Nesse caso, também seria possível a obtenção de retornos anormais.

A forma de eficiência semiforte pressupõe que o mercado reaja rapidamente ao conjunto de informações disponíveis publicamente. (FAMA, 1991).

3- Forma Forte da EMH: por fim, no extremo oposto da forma fraca, a forma forte considera que os preços das ações refletem a qualquer momento, todo tipo de informação, seja de preços passados, informações disponíveis ao público ou informações privilegiadas obtidas por pessoas de dentro das empresas e que são desconhecidas do mercado. Sob essa forma, toda a informação relevante disponível (fontes públicas e privadas - privilegiadas, preços passados; insiders, agentes do mercado que possuem informações relevantes que o mercado em geral não possui) está refletida nos preços correntes. (FAMA, 1991; IUDÍCIBUS; LOPES, 2004; ORTOLAN, 2006). Essa forma é a menos considerada, pois há poucas evidências empíricas confiáveis de que o mercado seja eficiente na forma forte, pois, se um 
indivíduo possuir algum tipo de informação que mais ninguém tem, é provável que possa ganhar com isso. (ROSS et al., 1995).

Assim sendo, primeiramente, um mercado deverá ser eficiente na forma fraca, contendo todas as informações dos retornos passados do título; sendo eficiente na forma fraca, poderá sê-lo na forma semiforte ao refletir todo o conjunto de informações publicamente disponíveis. Por fim, poderá ser considerado eficiente na forma forte se, além de conter todo o conjunto de informações disponíveis publicamente, também refletir o conteúdo das informações privilegiadas.

Lopes (2002, p. 5) propõe um suposto relacionamento qualitativo entre a informação contábil e a eficiência de mercado, conforme Quadro 1:

Quadro 1 - Informação Contábil e Eficiência de Mercado

\begin{tabular}{|c|c|c|}
\hline \multirow{2}{*}{ INFORMAÇÃO CONTÁBIL } & \multicolumn{2}{|c|}{ EFICIÊNCIA DE MERCADO } \\
\hline & Mercado Eficiente & Mercado Não eficiente \\
\hline Relevante & $\begin{array}{l}\text { Resposta rápida e imediata. O } \\
\text { mercado é capaz de avaliar notas } \\
\text { explicativas } \quad \text { e } \\
\text { evidenciações complexas como } \\
\text { derivativos, pensões etc.. }\end{array}$ & $\begin{array}{l}\text { A resposta não é rápida. O } \\
\text { mercado nem avalia a } \\
\text { informação, nem é capaz de } \\
\text { interpretar evidenciações mais } \\
\text { complexas. }\end{array}$ \\
\hline Irrelevante & Sem reação & Inconsistente \\
\hline
\end{tabular}

Fonte: LOPES, 2002

O autor explica que

[...] uma determinada informação ou conjunto de informações são relevantes em um mercado eficiente, então a resposta nos preços dos títulos deve ser rápida e imediata, sendo que os agentes possuem capacidade de interpretação dessas informações, desde as mais simples até as mais complexas. Se um conjunto de informações são relevantes a um mercado que não é eficiente, então o mercado demora algum tempo para absorver a informação, ou seja os agentes não avaliam prontamente ou até mesmo não conseguem avaliar se a informação é relevante, assim como possuem respostas retardadas ou até mesmo não possuem respostas às informações mais complexas. Mas o caso mais nebuloso é quando a informação não é relevante em um mercado não eficiente, o que pode apresentar reações indevidas sobre informações irrelevantes.

Os primeiros estudos indicaram ineficiência de mercado, como o de Contador (1975), e, até o princípio da década de 1990, os estudos existentes eram inconclusivos. Muniz (1980) e Amaral (1990) identificaram a forma fraca de eficiência de mercado e Leal e Amaral (1990) apontaram para a ineficiência desse mercado em relação ao mercado dos países desenvolvidos. 
Em 1995, Urrutia (1995) analisou os mercados do Brasil, México, Chile e Argentina, com retornos analisados em base mensal e que compreendiam o período de 1975 a 1991. Nesse caso, a hipótese de eficiência de mercado não foi verificada no Brasil. Schiehll (1996) notou a ocorrência da forma semiforte. Kawatsu e Morey (1999) observaram o processo de globalização dos mercados e chegaram à conclusão de que o processo de abertura não melhorou a sua eficiência, pois esses já eram eficientes antes. Entretanto, Perobelli e Ness Jr. (2000) não encontraram essa forma, pois constataram que o ajuste dos preços, por ocasião da divulgação de lucros, não é instantâneo.

Nesse período, o mercado financeiro brasileiro passou por grandes mudanças. A globalização, caracterizada pela intensificação do comércio internacional e acompanhada de maior integração financeira dos mercados mundiais, passou a demandar a adaptação do mercado brasileiro. (BAESSO et al., 2008) . Somado a isso, a estabilização da moeda, a partir de 1994, foi marcada por uma reestruturação da propriedade dos valores mobiliários, com maior participação de investidores individuais e estrangeiros, passando a haver, também, maior transparência das transações. (CAMARGO; BARBOSA, 2003). A partir de 2002, houve uma progressiva redução do risco-país, comumente interpretado como proxy para a incerteza do mercado brasileiro. Outro ponto está na movimentação internacional pela harmonização contábil, tendo o Brasil começado a seguir essa direção, como se depreende da análise das Deliberações n. 488 e n. 527 da CVM e do projeto de Lei n. 11.638/2007. A harmonização contábil visa a propiciar aos usuários das informações contábeis nos diversos países, informações confiáveis, relevantes, compreensíveis e comparáveis. Dessa forma, acredita-se que poderá contribuir para a redução dos custos de agência e para o aumento da eficiência do mercado de capitais brasileiro por reduzir a assimetria de informações. (BAESSO et al., 2008).

Mais recentemente, observa-se estudos que apontam um possível aumento da eficiência do Mercado de Capitais no Brasil. Romer (2001) discorre sobre a queda e o controle da inflação como fatores redutores da incerteza na economia. Ceretta (2001b) buscando obter um melhor entendimento do mercado latino-americano verificou a existência da aleatoriedade nos índices dos mercados da Argentina, Brasil, México e Chile por intermédio de dados semanais do período de 1990 a 1999. Os resultados demonstraram que os mercados argentino e brasileiro apresentam convergência com a hipótese do caminho aleatório. Camargos e Barbosa (2003) apontaram diversos artigos que foram unânimes em determinar o grau de eficiência do 
mercado brasileiro. Em 2004, Caldeira et al., (2004) constataram, por diversos testes estatísticos, a forma fraca de eficiência de mercado. Por fim, Baesso et al. (2008), por meio da aplicação de filtros ótimos, concluíram pela existência, pelo menos, da eficiência de mercado em sua forma fraca.

Nas primeiras pesquisas, é possível perceber resultados contraditórios: uns apontando eficiência e outros apontando ineficiência de mercado. Entretanto, mais recentemente, os estudos revisados que testaram somente a EMH apontam a existência, ao menos, de eficiência de mercado na forma fraca no mercado brasileiro. Em complementação a esses, estudos que testaram o impacto da informação contábil nos preços das ações assinalam para a existência de eficiência de mercado na forma semiforte. O tópico 2.1.1, a seguir, explana a ligação entre a EMH e a contabilidade.

\subsubsection{Hipótese de mercado eficiente e a contabilidade}

A EMH, em sua forma semiforte, define que as variações dos preços das ações incorporam todas as expectativas sobre as empresas. Essas expectativas são formadas pela incorporação de toda informação disponível que possa influenciar os preços dos ativos negociados (FAMA, 1970; LIMA; TERRA, 2004). Seguindo esse raciocínio, as informações publicamente disponíveis seriam refletidas nos preços das ações, o que inclui as informações contábeis.

Antes de prosseguir o raciocínio, é importante lembrar o conceito de valor de uma ação. Uma ação é avaliada pelos fluxos de caixa futuros e pelos riscos associados a eles. (ASSAF NETO, 2005; DAMODARAN, 2005; MARTINS et al., 2001; RAPPAPORT; MUBOUSSIN, 2002). Detalhadamente, isso quer dizer que o valor da empresa depende dos fluxos de caixa esperados e da respectiva taxa de retorno exigida pelo mercado, conforme os riscos do ativo. (WATTS; ZIMMERMAN, 1986). Dessa forma, os preços de mercado refletem as expectativas dos agentes econômicos acerca do futuro da empresa e da economia. (IUDÍCIBUS; LOPES, 2004; LOPES; MARTINS, 2005).

Por isso, os lucros contábeis de uma firma para o período corrente podem fornecer informação sobre os fluxos de caixas correntes e sobre os fluxos de caixa esperados. (SANTOS, 2008; WATTS; ZIMMERMAN, 1986). Isso se dá porque, apesar de 
metodologicamente diferentes, os fluxos de caixa e os lucros contábeis são ferramentas de mensuração de desempenho para a mesma entidade. São as entradas e saídas de caixa da empresa, os eventos fundamentais nos quais se baseiam as mensurações contábeis e nos quais se supõe que os investidores apoiem suas decisões. (HENDRIKSEN, VAN BREDA; 1992). Dessa maneira, onde o mercado é eficiente na forma semiforte, as informações geradas pela contabilidade deveriam estar incorporadas nos preços das ações. (SARLO NETO et al., 2004). Ross (1995, p. 267) corrobora esses conceitos afirmando que:

[...] um mercado é considerado eficiente no sentido semi-forte quando os preços refletem (incorporam) toda informação publicamente disponível, incluindo informações tais como relatórios financeiros publicadas pela empresa, bem como dados históricos de preço.

Sendo assim, se as informações contábeis devem ser refletidas nos preços das ações, qualquer variação no lucro contábil provocaria uma variação nos preços das ações. (SARLO NETO et al., 2006).

Como o mercado trabalha com expectativas futuras, visando aos fluxos de caixas futuros, isso implica que o mercado incorpora, antecipadamente, as informações contábeis esperadas ao preço das ações e esses somente se alterariam, posteriormente, se houvessem surpresas no momento da divulgação das informações, uma vez que novas informações não esperadas estariam sendo divulgadas para o mercado. (CUNHA; LUSTOSA, 2007). As variações dos lucros contábeis só terão conteúdo informacional, à medida que puderem sinalizar a ocorrência de fluxos de caixa não esperados. A surpresa causada pela informação contábil, no caso do lucro não esperado, nesse contexto, é o vetor que direciona um retorno anormal dos preços das ações. Como é possível constatar, a Hipótese de Eficiência de Mercado formou a base para que os pesquisadores pudessem verificar como o mercado se relaciona com a informação emanada pela contabilidade e quanto o mercado é eficiente a esse conjunto de informações.

Nesse contexto, encaixa-se o conceito de Information Approach (abordagem da informação), no qual a contabilidade é considerada como um meio de transmissão de informação. Sob a abordagem do Information Approach, as variáveis contábeis, como, por exemplo, o Patrimônio Líquido e o Resultado, possuem capacidade informacional. Essa capacidade informacional corresponde ao seu potencial de transmitir informações que influenciam as expectativas dos usuários. (LIMA et al., 2008; SARLO NETO et al., 2004). 
Os conceitos de que a contabilidade ultrapassa o paradigma normativo e é uma das principais fontes de informações para o mercado foram reconhecidos pelo FASB (Financial Accounting Standard Board) em 1978. Nessa data, esse órgão publicou o SFAC1 (Statement of Financial Accounting Concepts, 1978), em que declarou que o objetivo principal da contabilidade consiste em fornecer informações relevantes à tomada de decisão e completou: "o foco principal do relatório financeiro é a informação sobre o desempenho da empresa fornecida através das medidas de lucros e seus componentes." Resumidamente, o papel da contabilidade consagrou-se em "[...] prover os usuários dos demonstrativos financeiros com informações que o ajudarão a tomar decisões.” (IUDÍCIBUS, 2000, p. 20).

Assim, a contabilidade pode ser percebida como um sistema de informações organizado e dinâmico que contribui para o fortalecimento do Mercado de Capitais mediante a disponibilização de informações relevantes para o mercado. (LIMA et al., 2008; LIMA; TERRA, 2004). E para que seja útil, será necessário que ela guarde estreita relação com a realidade econômica, por sua capacidade de alterar ou confirmar expectativas sobre fluxos de caixa futuros dos ativos. (LOPES; MARTINS, 2005).

Num cenário, em que o mercado é eficiente na forma semiforte, as informações geradas pela contabilidade deveriam estar refletidas nos preços das ações. Então, nessa situação, haveria uma forte relação entre a contabilidade e o mercado, de forma que a alteração em uma variável contábil provocaria a variação dos preços das ações.

A despeito da relação preconizada pela teoria entre lucros contábeis e o preço das ações, os resultados mostrados em várias pesquisas não apresentaram correlação perfeita (igual a 1) entre si. As evidências encontradas assinalam que apesar de seguirem a mesma direção, lucros e preços apresentam variações com intensidades diferentes, ou seja, as variações positivas nos lucros estão relacionadas com variações positivas nos preços, mas não com a mesma escala de variação. (SARLO NETO et al., 2004). E foi esse tipo de questionamento que motivou os acadêmicos a saberem se os números contábeis tinham ou não conteúdo informacional. (IUDÍCIBUS; LOPES, 2004). Mas por que isso ocorre?

Parte do motivo para a falta de correlação perfeita está no fato de que os preços captam o impacto de um conjunto de informações muito mais amplo do que o representado apenas por lucros contábeis. Por exemplo, os preços reagem a coisas tão exóticas como boatos de guerra e tão corriqueiras quanto variações da taxa de juros de Letras do Tesouro. (HENDRIKSEN; VAN BREDA, 1999, p. 206) 
Também, Lima e Terra (2004, p. 2) apontam que, somado a isso, no caso brasileiro

\begin{abstract}
Apesar da relevância das demonstrações financeiras para o mercado de capitais, é discutível a sua eficiência: uma vez que estas informações são de natureza estática, enquanto o mercado é dinâmico. Esta dicotomia torna-se evidente quando analisado o prazo limite que a Comissão de Valores Mobiliários (CVM) instituiu para a entrega das demonstrações financeiras. De acordo com as Instruções CVM 202/93 e CVM 351/01, as empresas estão obrigadas à divulgarem suas Informações Trimestrais (ITR) no prazo máximo de 45 dias após o final do trimestre, e suas Demonstrações Financeiras Padronizadas (DFP) no prazo máximo de até 3 meses após o final do exercício social. Esta defasagem temporal entre o fato gerador e a sua posterior divulgação é uma desvantagem para o conteúdo informacional das demonstrações financeiras. Desta forma, os relatórios tendem a ser apenas confirmadores das expectativas dos investidores.
\end{abstract}

Dessa forma, os pesquisadores apontam que existem diversos elementos influenciando o preço de uma ação os quais não estão presentes no lucro da empresa ou, ao menos, não estão presentes de forma concomitante. Outros autores afirmam que a relação não é perfeita pois o lucro da empresa é composto por elementos originados somente da própria empresa e o preço é influenciado por elementos da empresa e várias outras informações.

Levando em consideração a importância da informação contábil para o Mercado de Capitais, no tópico 2.2, serão aprofundados os conceitos da Teoria do Portfólio e Risco com o intuito de levar ao leitor um maior entendimento da relação dessas ferramentas com os números contábeis.

\title{
$2.2 \quad$ Teoria de Portfólio
}

Em 1952 e concomitantemente com os avanços teóricos na economia, surge a Moderna Teoria de Portfólio dos estudos de Harry Markowitz que, como parte da sua tese para $\mathrm{PhD}$, tentava calcular como construir carteiras de ações com altas expectativas de retorno para determinado risco ou baixas possibilidades de risco para determinadas taxas de retorno. (SECURATO, 1993).

Na base de seu trabalho, Markowitz (1952) assumiu as premissas a seguir: 
- $\quad$ os investidores baseariam suas análises em projeções de rentabilidade para os ativos a partir da distribuição de probabilidades para as várias taxas de retorno que podem ser alcançadas no período do investimento;

- os investidores baseariam suas decisões somente em termos do retorno esperado e variância das taxas de retorno dos ativos para determinado período do investimento;

- $\quad$ os custos de transação e impostos seriam irrelevantes;

- $\quad$ para qualquer nível de risco, os investidores prefeririam maiores retornos a menores retornos ou, ainda, para qualquer nível de retorno esperado, os investidores prefeririam menos riscos;

- existiria uma taxa livre de risco na qual o investidor poderia tanto emprestar como tomar emprestado;

- os ativos seriam infinitamente divisíveis o que permitiria ao investidor comprar uma fração da ação.

Como resultado o autor constatou que:

- $\quad$ primeiramente, o risco é definido como sendo o desvio-padrão dos rendimentos dos ativos e o retorno esperado é a média desses mesmos rendimentos. (PERLIN; CERETTA, 2004);

- a expectativa de retorno para um portfólio de ações é a média dos retornos das próprias ações ponderadas pelo seu percentual de participação conforme a fórmula abaixo:

$$
E\left(R_{p}\right)=X_{1}\left(R_{\mu 1}\right)+X_{2}\left(R_{\mu 2}\right) \ldots+X_{n} E\left(R_{\mu n}\right)
$$

em que: $\mathrm{X}_{1}, \mathrm{X}_{2}, \mathrm{X}_{\mathrm{n}}$ representam o percentual dos recursos investidos em cada um dos títulos 1, 2, n, que compõem a carteira; $R_{\mu 1}, R_{\mu 2}, R_{\mu n}$ representam as médias dos retornos das ações de cada título da carteira;

- $\quad$ o risco depende da volatilidade das rentabilidades das ações e de como elas se correlacionam aos pares. A fórmula, a seguir, exibe o risco medido pela variância:

$$
\sigma_{p}^{2}=X^{2}{ }_{1} \sigma_{1}+X^{2}{ }_{2} \sigma_{2} \ldots+X_{n}^{2} \sigma_{n}+2 X_{1} X_{2} \operatorname{cov}_{12} \ldots+2 X_{1} X_{n} \operatorname{cov}_{1 n}+2 X_{2} X_{n} \operatorname{cov}_{2 n}
$$


em que: $X_{n}$ é igual ao percentual de participação da ação na carteira; $\sigma_{n}$ corresponde à variância do título e cov representa a covariância entre dois títulos (1 e 2). A covariância entre dois títulos é medida:

$$
\operatorname{Cov}_{1,2}=\frac{\sum\left(R_{1}-R_{\mu 1}\right) \cdot\left(R_{2}-R_{\mu 2}\right)}{n-1}
$$

sendo: $R_{1}$ o retorno do título a e b respectivamente em determinado período; $R_{\mu 1}$ retorno esperado do título 1 e 2, respectivamente e n é o número de observações. Segundo Ross et al. (1995, p. 206), a variância e o desvio-padrão medem a variabilidade de ativos individuais e para que seja possível relacionar o retorno e/ou risco de dois ou mais ativos é necessária a adoção da covariância e da correlação, as quais medem a intensidade com a qual duas variáveis estão associadas.

- quanto maior a probabilidade dos rendimentos futuros serem distantes do retorno esperado (média dos rendimentos), maior a probabilidade de um retorno negativo, aumentando, desse modo, o risco da ação ou carteira. (PERLIN; CERETTA, 2004);

- $\quad$ essa afirmativa é baseada na premissa de que os rendimentos dos ativos seguem uma distribuição normal, em que seu comportamento passado serve como base para o comportamento futuro, portanto, os primeiros e segundos momentos estatísticos são suficientes para caracterizar essa respectiva ação ou carteira.

O Portfolio Selection, publicado por Markowitz (1952), até hoje orienta profissionais e é fonte de inspiração de inúmeros trabalhos científicos. Devido à complexidade dos cálculos para a otimização de carteiras de ações, o trabalho de Markowitz só passou a ser utilizado com mais frequência após a criação do computador - talvez por isso só tenha sido premiado com o Nobel de Economia quarenta anos após a publicação de seu trabalho, em 1990. (BREALEY; MYERS, 2003). Graças a Markowitz, a própria noção de risco passou a ser vista de modo diferente. Sharpe (1967) diz considerar Markowitz como o pai da análise de carteiras, apontando esse trabalho como um dos pontos centrais da Teoria Financeira.

Evidências empíricas que testaram a Teoria das Carteiras e relacionaram a diversificação simples e a redução do grau de risco foram, primeiramente, obtidas por Evans e Archer (1968). Eles construíram 60 carteiras de $n$ ações $(n=1,2, \ldots, 40)$, selecionadas, de forma 
aleatória, de um conjunto de 470 títulos. O estudo abrangeu um período de 10 anos. Para cada uma das 60 carteiras de tamanho $n$, Evans e Archer calcularam a taxa de retorno médio e o desvio-padrão. Como um dos resultados de suas investigações, eles identificaram um relacionamento de forma decrescente e curvilíneo entre o número de ações e o grau de risco. (COROA et al., 2005).

Ross et al. (1995, p. 209) explicam que se houver uma relação direta entre o retorno de dois ativos, sua covariância será positiva; ao contrário, se houver uma relação inversa, a covariância será negativa. Existe, ainda, o caso de não haver relação entre os dois ativos e a covariância deverá ser nula. Sendo assim, uma covariância positiva aumenta a variância da carteira, enquanto uma covariância negativa reduz a variância da carteira. (NAKAMURA; MATIAS FILHO, 2006). Verdadeiramente, é possível combinar teoricamente ações bastante arriscadas individualmente quando medidas por seus desvios-padrão e formar uma carteira livre de risco não sistemático.

Um especial legado da Teoria de Portfólios foi a consagração da diversificação como estratégia de carteiras e a otimização da relação Risco e Retorno:

- A diversificação entre ações com baixas correlações entre os retornos dos títulos minimiza o risco da carteira. À medida que o coeficiente de correlação reduz, o risco para determinado nível de retorno diminui, podendo até chegar a zero quando a correlação for -1 , ou seja, à proporção que a correlação entre os ativos diminui, ocorre aumento do benefício da diversificação, aumentando o retorno para um mesmo nível de risco ou diminuindo o risco para um igual nível de retorno. De forma geral, buscaram subsídios matemáticos para explicar aquilo que já era familiar à Teoria de Investimentos, ou seja, a diversificação reduz o risco e um risco elevado deve oferecer um ganho elevado. (CERETTA, 2001b);

- A Otimização de carteiras dá-se atribuindo uma reta tangente à fronteira eficiente dos ativos, assim como também a utilização de multiplicadores de lagrange permitiram que Markowitz (1952) chegasse à equação algébrica que minimizasse o risco (desvio-padrão dos rendimentos) na carteira montada, em função dos pesos dos ativos participantes. (PERLIN; CERETTA, 2004). 
Assim, o retorno esperado de uma carteira é simplesmente a média ponderada dos retornos esperados dos ativos individuais da carteira. Entretanto, diferente dos retornos, o risco de uma carteira, geralmente, não é a média ponderada dos desvios-padrão dos seus ativos individuais; o desvio-padrão da carteira será menor do que a média ponderada dos desvios-padrão dos ativos.

\title{
2.2.1 Risco
}

Assaf Neto (2005, p. 207) explica que

\begin{abstract}
Toda vez que a incerteza associada a determinado evento possa ser quantificada por meio de uma distribuição de probabilidades dos diversos resultados previstos, diz-se que a decisão está sendo tomada sob uma situação de risco. Dessa maneira, o risco pode ser entendido pela capacidade de mensurar o estado de incerteza de uma decisão mediante o conhecimento das probabilidades associadas à ocorrência de determinados resultados ou valores. A idéia de risco de forma mais específica, está diretamente associada as probabilidades de ocorrência de determinados resultados em relação a um valor médio esperado. É um conceito voltado para o futuro, revelando uma possibilidade de perda.
\end{abstract}

Damodaran (2005) afirma que o risco aparece quando os retornos esperados pelos investidores, em um determinado horizonte de tempo, sofrem variação. Para Gitman (2003), o risco pode ser definido, no sentido mais básico, como a possibilidade de perda e, mais formalmente, como uma medida de mensuração da variabilidade de retornos esperados.

Assim, segundo os autores, risco refere-se à incerteza sobre um evento convertido a um número por mensuração. $\mathrm{O}$ risco está associado à possibilidade de que algum acontecimento desfavorável venha a ocorrer, porém, quando o termo risco se refere a investimentos, pode-se associá-lo à probabilidade de, efetivamente, se ganhar menos do que o retorno esperado; sendo assim, quanto maior a possibilidade de retornos baixos ou negativos, mais arriscado o investimento. (NAKAMURA; MATIAS FILHO, 2006).

O risco é, na maioria das vezes, representado pela medida estatística do desvio-padrão, ou variância, indicando-se o valor médio esperado e representativo do comportamento observado e a dispersão das variáveis em relação à média. (ASSAF NETO, 2005). 
Brealey e Myers (2003) colocam que a variância da rentabilidade dos ativos no mercado é o valor esperado do quadrado dos desvios relativos à rentabilidade esperada, dados pela equação:

$$
\sigma^{2}=\sqrt{\sum_{k=1}^{n} \frac{1}{n}}\left(R_{k}-R_{\mu}\right)^{2}
$$

em que: $R_{\mathrm{k}}$ é a rentabilidade efetiva e $R_{\mu}$ é a rentabilidade esperada. Para uma carteira de ativos, a variância será representada pela média dos quadrados das diferenças. O risco, medido pelo desvio-padrão é, simplesmente, a raiz quadrada da variância:

$$
\sigma=\sqrt{\sigma^{2}}
$$

A mensuração do risco deve, portanto, levar em conta tanto a média como o desvio-padrão da distribuição.

Ainda, o risco encontrado para um papel poderá ser dividido em dois conjuntos distinguíveis de risco (FLEURIET, 1978):

- o risco sistemático, não diversificável, ou exógeno é aquele que não pode ser eliminado mediante estratégias de diversificação. É o risco inerente ao sistema, o risco de mercado.

- o risco específico é próprio ao ativo financeiro em pauta. É um reflexo do risco de que alguma coisa acontece e afeta o ativo (e somente este). Esse risco desaparece com a diversificação.

Segundo os estudos, os dois tipos de risco são independentes.

O risco diversificável, idiossincrático, também chamado de específico ou não sistemático, é aquele inerente a uma empresa ou grupo de empresas específicas e pode ser eliminado pela diversificação dos investimentos. (ASSAF NETO, 2005; DAMODARAN, 2005). Uma diversificação possível do risco não sistemático é por meio da adoção de carteiras de ativos. 
Dessa forma, as ocorrências possíveis em empresas ou setores específicos podem ser diversificadas, ou seja, diluídas mediante a adoção de carteiras de ativos que contenham empresas representativas de diversos setores da economia, além de diferentes tipos de ativos. Em contrapartida, o anúncio de resultados abaixo das expectativas, uma nova regulamentação governamental específica ou um passivo desconhecido que emerge no balanço de uma empresa, são exemplos claros de riscos não sistemáticos, os quais certamente não irão afetar, significativamente, os demais ativos do mercado. (NAKAMURA; MATIAS FILHO, 2006).

O risco sistemático, não diversificável, ou de mercado, baseia-se em fatores que afetam, sistematicamente, a maioria das empresas, logo, esses não podem ser eliminados pela diversificação. É muito mais difuso, afetando todos ou quase todos os ativos. (DAMODARAN, 2005). Na visão de Nakamura e Matias Filho (2006), a incerteza que existe a respeito de condições econômicas gerais, tais como a taxa de câmbio, a inflação ou a própria taxa de juros, são exemplos de risco sistemático, pois essas condições afetam praticamente todos os ativos de uma mesma maneira. Segundo os autores, como a maioria dos ativos financeiros compõem partes de uma carteira de investimentos, o que importará será o risco da carteira ou, de outra forma, como um ativo em particular afeta o risco da carteira em que é mantido.

Assim, o risco de um investimento de capital pode ser dividido em duas categorias: diversificável e não diversificável e ambas compõem seu risco total.

\subsubsection{CAPM}

Sendo um resultado interpretativo do modelo de mercado ${ }^{1}$, o CAPM calcula que o retorno de um título, negociado em um mercado eficiente e em carteiras diversificadas, é função da relação entre risco e taxas de retorno requeridas. (IUDÍCIBUS; LOPES, 2004).

\footnotetext{
${ }^{1}$ Watts e Zimmerman (1986, p. 33) consideram que o modelo de mercado é uma descrição estatística da relação entre a taxa de retorno de um ativo i $\left(\mathrm{R}_{\mathrm{i}, \mathrm{t}}\right)$ e a taxa de retorno de um portifólio representativo de mercado $\left(\mathrm{R}_{\mathrm{m}, \mathrm{t}}\right)$, sob a premissa de que a distribuição conjunta desses dois retornos seja normal: bivariada. (FAMA, 1991, p. 6368). O modelo de mercado pode ser expressado por intermédio de uma função linear entre dois retornos: $R_{i, t}=\alpha_{i}+\beta_{i} R_{m, t}+\varepsilon_{i, t}$, em que $: \alpha_{i}=E\left(R_{i, t}\right)-\beta E\left(R_{m, t}\right) ; \beta_{i}=\frac{\operatorname{cov}\left(R_{i, t} R_{m, t}\right)}{\sigma^{2}\left(R_{m, t}\right)} \quad ; \varepsilon_{i, t}$ é o termo de erro da
} 
O CAPM calcula o retorno de um ativo por:

$$
E\left(R_{i, t}\right)=R_{f}+\beta_{i}\left[E\left(R_{m t}\right)-R_{f}\right]
$$

em que: $E\left(R_{i, t}\right)$ é o retorno esperado do título i, ajustado por sua contribuição de risco para uma carteira diversificada; $R_{f}$ é a taxa livre de risco; $E\left(R_{m t}\right)$ é o retorno esperado da carteira de mercado; $\beta_{i}$ é a medida de contribuição de risco do título i para a carteira de mercado, sendo medida por $\beta_{i}=\frac{\operatorname{cov}\left(\left(R_{i t}\right),\left(R_{m t}\right)\right)}{\sigma^{2}\left(R_{m t}\right)}$, corresponde à medida do grau em que determinado título tende a se mover em conjunto ou não com o mercado. (ASSAF NETO, 2005; BERGMANN et al., 2008; DAMODARAN, 2005; IUDÍCIBUS; LOPES, 2004; NAKAMURA et al., 2007).

O retorno de um título i é função da taxa livre de risco; da taxa de retorno esperada da carteira de mercado e da covariância entre a taxa de retorno do ativo i e da taxa de retorno da carteira de mercado. A diferença entre o retorno da carteira de mercado e o retorno do ativo livre de risco é denominada prêmio pelo risco, pois é a compensação por se estar correndo o risco de mercado. (IUDÍCIBUS; LOPES, 2004).

Assaf Neto (2005), Copeland et al. (2002), Damodaran (2005) e Rappaport e Mauboussin (2002) afirmam que o melhor método de medir o retorno exigido para o capital próprio é mediante o CAPM. Segundo explicam Martelanc et al. (2004, p. 131) o retorno de capital próprio pelo CAPM:

[...] é a soma do retorno de um ativo sem risco com um prêmio pelo risco. Esse prêmio é o diferencial de retorno entre o retorno da carteira de mercado e o do ativo livre de risco, ponderado por um fator que indica o grau de sensibilidade do ativo em questão às variações no retorno desse diferencial.

regressão com $\mathrm{E}\left(\varepsilon_{i, t} / R_{m, t}\right)=E\left(\varepsilon_{i, t}\right)=0$ com variância $\sigma^{2}\left(\varepsilon^{2}\right)$. Nesse modelo, as variações dos retornos dos títulos individuais decorrem do risco diversificável $\alpha_{i}$ somado à relação da empresa com fatores gerais de mercado $\beta_{i} R_{m, t}$ e um termo de erro. À medida que a carteira é diversificada e são incluídos outros ativos com seus riscos diversificáveis, o risco diversificável $\alpha_{i}+\varepsilon_{i, t}$ tende a desaparecer, remanescendo somente o risco sistemático , $\beta_{i} R_{m, t}$. (IUDÍCIBUS; LOPES, 2004). 
Dessa forma, o retorno de um título é formado por duas partes: a taxa do ativo livre de risco e o prêmio pelo risco.

Considerando a premissa que os investidores são racionais e trabalham buscando a melhor opção de investimento, eles diversificam seus investimentos a fim de que sejam evitados os riscos individuais (inerente às empresas/ativos individuais), exigindo retorno adicional apenas pelo risco sistemático. Dessa maneira, o risco sistemático deve ser mensurado de modo a auxiliar a busca desse prêmio de risco adicional. (NAKAMURA; MATIAS FILHO, 2006).

Se o risco total é a soma entre risco sistemático (não diversificável) e risco não sistêmico (diversificável) e os participantes do mercado diversificam eficientemente suas carteiras, ou seja, eliminam o risco diversificável, o único componente que sobra para a análise do risco total é o risco sistemático. Se o mercado está em equilíbrio para a relação risco e retorno, a dinâmica do retorno é unidimensional, então, o risco sistemático de um ativo será suficiente para quantificar seu retorno exigido. (PERLIN; CERETTA, 2004).

O ponto básico do modelo é que os ativos se comportam de acordo com os movimentos do mercado (up e down market). Diferenciando ativos em função de sua aderência ao comportamento de mercado, é possível quantificar o retorno exigido em função de seu risco sistemático (não diversificável).

Por essa razão, o que salta aos olhos para os investidores de mercado é o beta de um ativo. Isso ocorre, pois, dentro do CAPM, se define o valor da sensibilidade aos movimentos do mercado como sendo indicativo do grau de risco sistemático do ativo ou carteira. Tal propriedade é medida pela covariância do ativo com a carteira de mercado dividido pela variância da carteira representante do mercado, popularmente conhecido por índice beta. Exemplificando: se o mercado render $10 \%$ e o ativo possuir beta igual a 0,2 , o rendimento do papel será de $2 \%$. Assim, um ativo com maior valor de beta, quando comparado com ações de pequenos betas, deve apresentar maior retorno positivo ou, em caso de down market, um rendimento negativo extremo. (DAMODARAN, 2005).

$\mathrm{Na}$ verdade, o CAPM é baseado em um mercado em equilíbrio e, como tal, todas as suposições subjacentes aos mercados eficientes são incorporadas a ele. 


\title{
2.2.2.1 CAPM e a informação contábil
}

Hendriksen e Van Breda (1992, p.184) explicam que

\begin{abstract}
A EMH e o CAPM significam que a nova informação relevante exercerá um efeito imediato sobre o preço de um título, seja alterando expectativas a respeito do retorno médio de um título, seja alterando expectativas quanto ao seu beta. Se as expectativas de todos os investidores forem homogêneas, uma variação do preço do título relativamente aos preços de todos os títulos no mercado será uma indicação de que a nova informação afeta as expectativas. Uma das implicações importantes do CAPM reside em fornecer uma forma de testar o efeito da divulgação das novas informações.
\end{abstract}

A ligação entre os dados contábeis e o CAPM é direta, pois a contabilidade fornece dados passados sobre os diversos fluxos de caixa e informações que possibilitam a projeção de dados futuros. Como foi dito anteriormente, o lucro é uma das principais figuras contábeis utilizadas como substituto do fluxo de caixa. Assim sendo, os lucros passados podem ser grandes fontes de informações sobre lucros futuros e, indiretamente, dos fluxos de caixa futuros. (IUDÍCIBUS; LOPES, 2004).

Se o valor de uma empresa (ação) é igual ao valor presente dos fluxos de caixa futuros, dados pelas taxas de retornos requeridas para a entidade (expressas pelo CAPM) e, caso informações contábeis alterem expectativas sobre o fluxo de caixa futuro, as taxas de juros requeridas também serão alteradas, implicando alterações de preços correntes. (FAMA, 1970; LIMA; TERRA, 2004).

Assim, o CAPM e a contabilidade são os componentes essenciais para a formação do valor de uma empresa e operam juntos na fórmula de avaliação de ativos.

Iudícibus e Lopes (2004, p. 91-92) explicam que

\begin{abstract}
Outro aspecto relevante entre o CAPM e as informações contábeis são as possíveis indicações de risco que essas informações podem possuir. Se as alterações de informações contábeis estiverem relacionadas a alterações de risco, a informação será relevante e irá alterar a taxa de retorno requerida da empresa. Caso isso não ocorra a informação tanto pode não ser relevante quanto pode estar confirmando expectativas do mercado.
\end{abstract}

Dessa forma, o CAPM aliado à EMH oferece à contabilidade ferramentas importantes para se testarem, empiricamente, o impacto das informações contábeis nos preços dos títulos. E outro ponto é que as informações advindas da contabilidade podem contribuir para o cálculo do CAPM, sempre que influenciarem a perspectiva de risco da empresa. 
No item seguinte, será analisado mais de perto, o beta, componente do CAPM que forma o risco sistemático do ativo e sua possível relação com a contabilidade.

\subsubsection{Beta}

O risco sistemático ou de mercado pode ser medido pelo grau em que uma determinada ação (investimento) tende a subir e a descer com o mercado, e essa tendência de uma ação moverse com o mercado é refletida em seu coeficiente beta, que é a medida da volatilidade da ação em relação à de uma ação média. O beta corresponde ao percentual de risco sistemático que afeta a ação, porém esse percentual é calibrado pelo risco diversificável.

Conforme Ross et al. (1995, p. 248), “[...] em palavras, isso quer dizer que o beta é a covariância do retorno de um título com o retorno do mercado, dividida pela variância do retorno do mercado."

"Assim, já que o beta de uma ação mede sua contribuição ao fator risco de uma carteira o beta é a medida teoricamente correta do fator risco da ação." (WESTON; BRIGHAM, 2000, p. 177). A equação para cálculo do beta é a seguinte:

$$
\beta_{i}=\frac{\operatorname{cov}\left(\left(R_{i t}\right),\left(R_{m t}\right)\right)}{\sigma^{2}\left(R_{m t}\right)}
$$

em que: $\mathrm{R}_{\mathrm{it}}$ é a taxa de retorno do ativo i e $\mathrm{R}_{\mathrm{m}}$ a taxa de retorno do ativo de mercado $\mathrm{m}$.

O cenário de estimação do índice beta leva em conta três decisões importantes: a amplitude do período de estimativa; o intervalo de retornos considerado e o índice representativo do ativo de mercado a ser escolhido. Por ser uma medida de volatilidade, o índice beta mostra quanto será a variabilidade provável do ativo individual diante da oscilação do ativo de mercado. (NAKAMURA; MATIAS FILHO, 2006).

Para a compreensão mais detalhada do fator beta, Damodaran (2005; p. 69-71) explica que 
a) Tipos de negócios: Como os betas medem o grau de risco de uma empresa relativamente a um índice de mercado, quanto mais sensível às condições de mercado for o negócio mais alto será o beta.

b) Grau de alavancagem operacional: É uma função da estrutura de custos da empresa e é usualmente definido em termos de custos definidos entre custos fixos e custos totais. Uma empresa com alto grau de alavancagem operacional, isto é, custos fixos elevados em relação a custos totais, também terá uma maior variabilidade nos lucros antes do pagamento de juros e impostos (EBIT), o que leva a níveis de risco maiores e betas maiores do que uma empresa que produza um produto semelhante com baixo grau de alavancagem operacional.

c) Grau de Alavancagem financeira: empresas mais alavancadas financeiramente tendem a apresentar betas maiores. Isto ocorre porque os juros sobre capital de terceiros, são como custos fixos, e independem do resultado da empresa. Desta forma estes permitem um aumento mais que proporcional nos anos bons e uma queda mais que acentuada nos anos ruins, aumentando assim a variabilidade dos retornos.

Sendo assim, o beta é o fator que pondera o prêmio de risco do mercado, pelas características de risco da própria empresa. Esse fator é produto do coeficiente de risco da ação de uma empresa com relação a uma carteira de mercado que representa o mercado acionário. Nesse coeficiente, estão representadas as influências de risco diversificável do tipo de negócio e de alavancagem operacional e financeira. Em resumo, o Beta calibra o prêmio de risco do mercado, em relação ao ativo livre de risco, pelas características do risco da própria empresa, formando o prêmio de risco (específico) da empresa.

Damodaran (2005) propõe três variações no cálculo do beta: beta não alavancado, beta ascendente e beta contábil.

O Beta não alavancado foi criado por Hamada (1971) e se propôs a minimizar o efeito da alavancagem financeira presente no beta histórico. A equação proposta para reduzir o efeito da alavancagem financeira do beta corrente é a seguinte:

$$
\beta_{i \text { não alavancado }}=\frac{\frac{\operatorname{cov}\left(\left(R_{i t}\right),\left(R_{m t}\right)\right)}{\sigma^{2}\left(R_{m t}\right)}}{1+\left(1-\operatorname{ló}_{0} I R\right)(\text { ívida } / P L)}
$$

em que: $\frac{\operatorname{cov}\left(\left(R_{i t}\right),\left(R_{m t}\right)\right)}{\sigma^{2}\left(R_{m t}\right)}$ é o beta do ativo, \%IR é a alíquota de IR, dívida corresponde ao passivo exigível e PL ao patrimônio líquido, ou seja, é o beta do ativo equacionado pelo seu grau de endividamento. 
O Beta Ascendente é aquele calculado a partir do beta do setor. Damodaran (2005, p. 185) divide os betas em seus componentes de risco de setor e de alavancagem financeira, fornecendo, assim, uma forma alternativa de cálculo de beta sem a necessidade de se obterem preços passados da empresa ou valor de seus ativos. Para tanto, é usada uma propriedade dos betas que é a de que "o beta de dois ativos somados é uma média ponderada do beta de cada um deles, com os pesos baseados em seu valor de mercado". O autor propõe o cálculo do beta em quatro etapas: identificar o setor de atuação da empresa; estimar o beta não alavancado de outras empresas desse setor negociadas publicamente; obter uma média ponderada dos betas não alavancados usando a proporção do valor do patrimônio líquido das empresas; determinar o valor médio do patrimônio líquido e de dívida das empresas de forma a obter o índice dívida/patrimônio líquido, utilizado para estimar um novo beta alavancado. (NAKAMURA; MATIAS FILHO, 2006, p. 8). O beta ascendente utiliza, portanto, a expressão a seguir:

$$
\beta_{\text {i ascendente }}=\beta_{\text {i não alavancado }} *\left(1+(1-\% I R) \cdot\left(\frac{\text { dívida }}{P L}\right)\right)
$$

em que: $\frac{\operatorname{cov}\left(\left(R_{i t}\right),\left(R_{m t}\right)\right)}{\sigma^{2}\left(R_{m t}\right)}$ é o beta do ativo, \%IR é a alíquota de IR, dívida corresponde ao passivo exigível e PL ao patrimônio líquido, ou seja, é o beta do setor equacionado pelo seu grau de endividamento do ativo.

O Beta Contábil utiliza-se de uma comparação entre as mudanças nos lucros das empresas e as mudanças no lucro do mercado, num mesmo período, deduzindo-se o retorno do ativo livre de risco, resultando no beta contábil. (NAKAMURA; MATIAS FILHO, 2006, p. 8). Para Beaver e Manegold (1975, p. 231), o beta contábil de um ativo é dado pela covariância entre a série de retornos contábeis do ativo e a série de retornos de um índice econômico global dividida pela variância dos retornos do índice econômico global. Já para Hill e Stone (1980, p. 596), o beta contábil é utilizado como um termo genérico para a sensibilidade sistemática de uma medida de retorno contábil em relação a um índice global desse mesmo retorno. Segundo Brealey e Myers (2003), o seu cálculo envolve a comparação da variação do lucro da empresa analisada com a variação do lucro de todas as empresas do setor ou mercado, uma vez que os lucros das empresas estabelecem relação com as realidades econômicas subjacentes.

O nome beta contábil é consequência dos dados imputados no modelo, pois, no lugar de dados obtidos no mercado acionário, o investidor utiliza dados provenientes das informações 
contábeis, sendo utilizadas as médias e variâncias do índice como estimação do risco da empresa. A equação básica para cálculo do beta contábil é dada por:

$$
\beta_{i \text { cont ábil }}=\frac{\Delta \text { Lucro contabil empresa }-R_{f}}{\Delta \text { Lucro contábil mercado }-R_{f}}
$$

em que: $\Delta=$ a variação do lucro da empresa e do setor em um período e $R_{f}=$ a taxa livre de risco.

Segundo Iudícibus e Lopes (2004), como o mercado acionário não é tão representativo da economia do país, o beta contábil pode ser um substituto do beta de mercado. Para Weston e Brigham (2000, p. 591), "uma regressão do poder de lucro básico de uma empresa (LAJIR/Ativos Totais), com o passar do tempo, em oposição ao poder de lucro básico de uma grande amostragem de empresas."

Reforçando essa ideia, Copeland et al. (2002) e Damoram (1997) argumentam que para empresas que não negociam títulos mobiliários em Bolsas, a definição objetiva do Custo de Capital Próprio torna-se mais complexa. Dessa forma, dentre outras alternativas, sugere que esse tipo de empresa possa ser avaliado por meio da estimação de taxas de desconto com base em betas contábeis, ou seja, um beta contábil é estimado a partir dos lucros e não dos retornos. Logo, os lucros periódicos da empresa são regredidos contra os lucros agregados do setor ou índice que melhor represente o setor no qual a empresa está inserida.

De forma mais objetiva, Cardoso e Martins (2004) propõem que o beta contábil seja obtido a partir da equação da reta de regressão entre ROI-ajustado (LAJIR/Ativo total) de uma empresa e o ROI-ajustado (LAJIR/Ativo total) do setor de mercado no qual está inserida a empresa, acreditando que o lucro antes do Imposto de Renda e do resultado financeiro (LAJIR ou EBIT), utilizado em detrimento do lucro líquido (LL), minimize as distorções causadas pelas alterações no regime de tributação ao longo do tempo e da estrutura de financiamento de cada empresa.

Justifica-se a utilização desse indicador de rentabilidade, considerando que o investidor, ao assumir riscos, procura apoiar-se em medidas de eficiência e rentabilidade, muito embora não sejam apenas esses que nortearão o suprimento da incerteza, porém há de se considerar sua 
importância, pois o ROA-ajustado determinará um índice que medirá a capacidade de geração de lucros a partir dos seus ativos.

Portanto, pode-se definir o beta contábil mediante a seguinte dotação matemática:

$$
\beta_{c}=\frac{\operatorname{Cov}\left(R O I_{i,} R O I_{m}\right)}{\sigma^{2} R O I_{M}}
$$

em que:

$\beta_{c}=$ Beta Contábil (Risco);

$R O I_{i}, R O I_{m}=$ Retorno sobre o Investimento ajustado da empresa e do mercado, respectivamente;

$\operatorname{Cov}\left(R O I_{i}, R O I_{m}\right)=$ Covariância entre o ROI-ajustado da empresa e o ROI-ajustado do mercado;

$\sigma^{2} R_{M}$ = Variância do ROI-ajustado do mercado.

Assim sendo, se o lucro contábil for um aproximador do fluxo de caixa, um beta contábil será um aproximador do beta da entidade e será mais provável que os lucros contábeis possam ser estimadores para obter o beta da entidade. Normalmente, a literatura de análise de balanço apresenta a forma da rentabilidade do ativo como o quociente de lucro líquido e o total dos ativos. (IUDÍCIBUS; LOPES, 2004).

A maior parte dos autores define beta contábil como uma medida análoga ao beta de mercado, simplesmente substituindo taxas de retornos de ações por medidas de retorno contábil e utilizando índices contábeis consolidados para todas as empresas como índice de mercado:

Beaver e Manegold (1975, p. 231):

O beta contábil de um ativo é a relação entre a covariância de uma série de retornos do ativo com uma série de retornos de um índice de mercado, divididos pela variância dos retornos desse índice de mercado. ${ }^{2}$ (tradução nossa)

Hill e Stone (1980, p. 596):

2 "A security's accounting beta is the ratio of the covariance of a security's accounting return series with an economy-wide index of accounting returns divided by the variance of the economy-wide returns." 
usamos beta contábil como um termo genérico para a sensibilidade sistemática de alguma medida de retorno contábil ao mesmo retorno contábil de um índice de mercado. Um beta contábil é o análogo de contabilidade para o beta de mercado. Implícita na analogia está a suposição de que os retornos contábeis são gerados por um processo estatístico estruturalmente semelhantes aos retornos das ações. ${ }^{3}$ (tradução nossa)

Em relação ao retorno contábil a ser utilizado, sugerem-se várias medidas diferentes e até a utilização de fluxos de caixa ao invés de lucros. Pereiro (2002, p. 125) define um beta contábil como uma medida que "reflete a sensibilidade dos retornos contábeis de uma empresa em relação aos retornos contábeis do mercado inteiro", acrescentando que os retornos contábeis podem ser calculados tanto a partir do lucro operacional quanto do lucro líquido e que o retorno contábil do mercado pode ser calculado tanto se utilizando empresas listadas em Bolsa (um método híbrido entre contábil e mercado) quanto todas as empresas do mercado (listadas e não listadas).

No capítulo 3, serão apresentados os principais estudos encontrados pela revisão bibliográfica que relacionam informações contábeis e mercado de capitais e variáveis contábeis e risco de uma empresa, no exterior e no Brasil.

\footnotetext{
3 "We use accounting beta as a generic term for the systematic sensitivity of some measure of accounting return to a broad-based index of that same return. An accounting beta is an accounting analogue to the market beta. Implicit in the analogy is the assumption that accounting returns are generated by a statistical process structurally similar to that generating stock market returns."
} 


\subsection{Pesquisas sobre a informação contábil e o mercado de capitais}

Segundo Kothari (2001), uma grande fração dos estudos em contabilidade examinam a relação entre as demonstrações contábeis e o mercado de capitais. As chamadas capital market research (pesquisas em mercados de capitais) podem ser divididas em seis grande linhas, segundo o autor: análise fundamentalista e avaliação; value relevance; relação de impostos e mercados de capitais; testes de eficiência de mercado; papel da contabilidade em contratos e no processo político; regulação da evidenciação (disclousure). O autor lembra que essas grandes linhas de pesquisa não são mutuamente excludentes nem coletivamente exaustivas.

Começando da última para a primeira classificação, as pesquisas em Disclousure tratadas com destaque por Dye (2001) e Verrecchia (2001) consistem no estudo da evidenciação de informações contábeis e demais informações compulsórias ou voluntárias, que a empresa venha oferecer a seus stakeholders. (LIMA, 2007). As pesquisas sobre o papel da contabilidade em contratos e no processo político enfocam o papel da contabilidade como fornecedora de informações para a elaboração e o monitoramento contratuais. (HEALY; PALEPU, 2001). Já as que estudam a relação entre impostos e mercado de capitais são centradas principalmente na coordenação dos fatores tributados e não tributados, nos efeitos dos impostos no preço das ações e na discussão das taxas no comércio internacional.

As pesquisas em eficiência de mercado observam se preços de mercado refletem, plenamente, toda informação disponível, (FAMA, 1970;1991). Esses estudos concentram-se em dois tipos: estudo de eventos em curto e longo prazos e testes de dados setoriais. Nos estudos de eventos são verificadas (KOTHARI, 2001):

- $\quad$ ocorrências após o anúncio de resultados;

- $\quad$ eficiência de mercado em relação a métodos contábeis, bem como a mudanças nesses critérios e métodos;

- fixação do mercado em números (lucro por ação), independentemente do modo como foram calculados (princípio da fixação funcional nos números e não na informação);

- $\quad$ gerenciamento de accruals e análise de previsões (otimismo dos analistas);

- $\quad$ retornos de longo prazo para ofertas públicas iniciais. 
Diferentemente do estudo de eventos, nos testes de dados setoriais/transversais (crosssectional) são observadas se as previsões de retornos e os retornos sobre portfólios de empresas são consistentes com o modelo de retornos esperados como o CAPM. (KOTHARI, 2001). Além disso, como a base teórica das pesquisas em mercado de capitais está fundamentada na Hipótese de Eficiência de Mercado, todas elas acabam verificando essa hipótese.

As pesquisas em value relevance e análise fundamentalista e valuation formam o pano de fundo das análises em que se encontra este trabalho, assim serão apresentadas de forma mais detalhada na sequência.

\subsubsection{Análise Fundamentalista e Valuation}

Em um mercado eficiente, o valor da firma é definido como o valor presente dos fluxos de caixas futuros esperados, descontados pela apropriada taxa de juros ajustada ao risco do retorno, ou seja, retorno esperado (CAPM). (ASSAF NETO, 2005; BUFFETT, 1992; DAMODARAN, 2005; KOTHARI, 2001; LOPES, 2002; MARTINS et al., 2001; YOUNG; O’BYRNE, 2003). Já os preços das ações não correspondem diretamente a esse valor, mas convergem para o valor previsto pelos fluxos de caixa e retorno esperado. (KOTHARI, 2001).

Na contabilidade, o desempenho financeiro é resumido nas demonstrações financeiras, porém não é esse o único input que o mercado acessa para a formulação dos fluxos de caixa futuros e valor da empresa. Por isso, é esperada uma associação temporal entre fluxos de caixa correntes e futuros fluxos de caixa, bem como uma associação contemporânea entre o lucro e o retorno da ação. (HENDRIKSEN; VAN BREDA, 1992; KOTHARI, 2001; WATTS; ZIMMERMAN, 1986). Esse conceito vai ao encontro da estrutura conceitual do FASB de que as demonstrações financeiras devem ajudar investidores e credores a avaliar quantias, tempo e incertezas dos fluxos de caixa futuros.

Na sequência desses conceitos, uma importante meta da pesquisa em mercado de capitais é prover evidências dessas relações entre a contabilidade e os preços das ações. O foco da 
análise fundamentalista é usar a informação das demonstrações contábeis presentes e passadas, em conjunto com dados macroeconômicos e setoriais, para chegar ao valor intrínseco da firma e identificar erros nos preços das ações (mispriced securities). (KOTHARI, 2001). Entretanto, é crescente a ideia de que a convergência do preço para o valor é um processo mais lento do que as evidências iniciais sugerem.

Para melhor entendimento das ferramentas de avaliação e sua ligação com os dados contábeis, são apresentados, de forma breve, os principais modelos de avaliação de ativos.

\subsubsection{Modelos de avaliação de ativos}

De modo geral, o que se observa é que a informação contábil vem adquirindo espaço significativo na composição das variáveis dos modelos de avaliação, ou seja, a contabilidade torna-se imprescindível no processo de realização de previsões e avaliações econômicas das empresas. Assim, o tamanho interesse por essas áreas de pesquisa ainda encontra espaço para crescimento, pois oferece muitas oportunidades e desafios.

A mais notória metodologia de avaliação de empresas tem suas origens no trabalho de Modigliani e Miller de 1961, intitulado "Dividend policy, growth and valuation of shares". A partir desse trabalho, variantes da metodologia proposta foram surgindo, mas as características essenciais do modelo se mantiveram desde aquela época. Atualmente, os modelos de desconto de fluxo de caixa (do inglês Discounted Cash Flow - DFC) correspondem à metodologia mais utilizada em avaliação. (ASSAF NETO, 2005; BUFFETT, 1992; MARTINS et al., 2001). Copeland et al. (2002, p. 22), Damodaran (2005, p.12) e Martins et al. (2001) explicam que isso ocorre pois o modelo DFC é tido como aquele que melhor revela a efetiva geração de riqueza de determinado empreendimento por exigir informações completas das variáveis contábeis e características do negócio.

O cálculo do valor pelo modelo DFC é determinado pelo fluxo de caixa projetado, descontado por uma taxa que reflita o risco associado ao negócio. (ASSAF NETO, 2005; BUFFETT, 1992; DAMODARAN, 2005; MARTINS et al., 2001; YOUNG; O’BYRNE, 2003). Esse conceito segundo Martin e Petty (2004, p. 7) é "sem dúvida uma das pedras fundamentais de finanças." 
Young e O’Byrne (2003, p. 33) explicam que

[...] o método DFC é função de três principais fatores: magnitude, timing e grau de incerteza dos fluxos de caixa.

[...] Magnitude ou tamanho dos fluxos de caixa, significa que quanto maiores os fluxos de caixa esperados melhor para o investidor.

[...] Timing considera os momentos que ocorrerão, quanto mais cedo se espera receber determinado fluxo de caixa, mais ele valerá na data presente.

[...] A incerteza dos fluxos de caixa está em que, uma vez que tais fluxos ocorrerão no futuro, haverá sempre risco de que ele não se materializará como planejado. Nessa abordagem os fluxos de caixa futuros são projetados e depois, então, descontados a uma taxa de juros ou taxa de retorno que reflita o risco esperado associado a tais fluxos.

Pelo método DFC o valor é obtido por meio dos fluxos de caixa projetados trazidos a valor presente por uma taxa que remunere o capital investido.

O método de desconto de fluxo de caixa para a empresa consiste em descontar os fluxos de caixa futuros de todos os detentores de direitos por uma taxa que remunere o custo do capital total investido na empresa. (ASSAF NETO, 2005; DAMODARAN, 1994; MARTINS et al., 2001).

Desse modo, o valor de uma empresa é formado pelo valor presente dos fluxos de caixa livres esperados. Se, por exemplo, a empresa, após $n$ anos, alcançar uma situação de equilíbrio e começar a crescer a uma taxa de crescimento estável $g$, o valor da empresa será descrito como (DAMODARAN, 1994):

$$
\text { Valor da empresa }=\sum_{t=1}^{n} \frac{\mathrm{FCFF}_{\mathrm{t}}}{(1+\mathrm{WACC})^{\mathrm{t}}}+\frac{\mathrm{FCFF}_{\mathrm{n}+1}}{\frac{\mathrm{WACC}-\mathrm{g}}{(1+\mathrm{WACC})^{\mathrm{t}}}}
$$

em que:

FCFF= Fluxo de Caixa Livre da Empresa (do inglês Free Cash flow to the firm);

WACC $=$ Custo Médio Ponderado de Capital (do inglês Weighted Average Cost of Capital);

$\mathrm{g}$ = taxa perpétua de crescimento dos fluxos de caixa da empresa;

$\mathrm{t}=$ ano $\mathrm{t}$. 
A aplicação do método do DFC para a empresa requer a determinação de três componentes principais: os fluxos de caixa livres projetados FCFF; o valor residual projetado $(F C F F t+1)$ e a taxa de desconto (WACC). (RAPPAPORT, 2001).

O FCFF são os fluxos de caixa que sobram após o pagamento de despesas operacionais, impostos, investimentos em capital de giro e em ativos permanentes, mas antes que sejam realizados quaisquer pagamentos a detentores de capital. (DAMODARAN, 2005; MARTINS et al., 2001; MARTIN; PETTY, 2004;YOUNG; O’BYRNE, 2003).

Segundo Martins et al. (2001, p. 263) e Damodaran (2005, p. 618), o FCFF é apurado pela projeção e esquematização das seguintes contas futuras:

Receitas líquidas de vendas

(-) Custo das Vendas

(-) Despesas operacionais

(=) EBIT - Earnings Before Interest and Tax

(-) Imposto de Renda / Contribuição Social

(=) NOPAT - Net Operation Profit After Tax

(+) Despesas operacionais que não provocam saída de caixa (Depreciação)

(=) Geração de caixa operacional

(-) Investimentos (ou desinvestimentos)

- Ativos Fixos

Capital de Giro

(=) Free cash flow to firm - FCFF

Outra forma de cálculo consiste em se apurar o valor da ação, encontrar o valor para o acionista. O fluxo de caixa para o acionista (FCFE - Free Cash Flow to Equity) é o fluxo de caixa existente após o pagamento de despesas operacionais, juros e principal, e de qualquer desembolso de capital necessário à manutenção da empresa. Pode ser obtido pela subtração do valor da empresa pelo total de dívidas atualizado. (Damodaran, 2005; Martins et al. 2001).

$$
\text { Valor da ação }=\sum_{t=1}^{n} \frac{\mathrm{FCFE}_{\mathrm{t}}}{\left(1+\mathrm{k}_{\mathrm{e}}\right)^{\mathrm{t}}}+\frac{\text { FCFE } \mathrm{n}+1}{\frac{\mathrm{k}_{\mathrm{e}}-\mathrm{g}}{\left(1+\mathrm{k}_{\mathrm{e}}\right)^{\mathrm{t}}}}
$$


em que:

FCFE= Fluxo de Caixa Livre do Acionista (do inglês Free Cash flow to Equity);

$\mathrm{k}_{\mathrm{e}}=$ Custo do Capital Próprio;

$\mathrm{g}$ = taxa perpétua de crescimento dos fluxos de caixa da empresa;

$\mathrm{t}=$ ano $\mathrm{t}$.

Já o fluxo de caixa para o acionista (FCFE - Free Cash Flow to Equity) é o fluxo de caixa existente após o pagamento de despesas operacionais, juros e principal, e de qualquer desembolso de capital necessário à manutenção da empresa. Pode ser obtido pela subtração do valor da empresa pelo total de dívidas atualizado (Damodaran, 2005; Martins et al. 2001).

Segundo Damodaran $(2005,621)$ é formado por:

Receitas líquidas de vendas

(-) Custo das Vendas

(-) Despesas operacionais

(=) Lucro antes dos juros e tributos (LAJIR - EBIT - Earnings Before Interest and Tax)

(-) Imposto de Renda / Contribuição Social

(-) Despesas financeiras

(=) Lucro Operacional

(+) Despesas operacionais que não provocam saída de caixa (Depreciação)

(=) Geração de caixa operacional

(-) Investimentos (ou desinvestimentos)

- Permanentes

- Capital de Giro

(-) Pagamentos de principal

(+) Entradas de caixa decorrentes de novas dívidas

$=$ Free Cash Flow to Equity - FCFE

Assim, o valor para o acionista é calculado pelos FCFE, trazidos a valor presente por uma taxa que remunere o capital próprio da empresa, $\mathrm{k}_{\mathrm{e}}$, o retorno esperado da empresa. Essa taxa corresponde ao retorno calculado pelo CAPM já descrito em tópicos anteriores.

É possível observar que o fluxo de caixa é formado por projeções de variáveis contábeis. Por essa razão, a informação contábil é uma das bases para a elaboração dos fluxos de caixa futuros e assim a avaliação da empresa, como: vendas; margens; estrutura de custos; necessidades de investimentos entre outras. (CERBASI, 2003). Além disso, é possível serem 
constatadas as especulações de Watts e Zimmerman (1986) de que os fluxos de caixa correntes são as melhores estimativas para os fluxos de caixa futuros e esses primeiros, possuem proximidade com os lucros contábeis.

Como vantagens, é importante destacar que o modelo DCF avalia, de forma mais aprofundada, os negócios da empresa, trabalhando para isso com as variáveis contábeis e perspectivas do negócio. Também, destacam sua maior complexidade teórica e aprofundamento das variáveis analisadas, buscando proporcionar maior precisão ao processo de avaliação. Já a complexidade da ferramenta acaba sendo uma desvantagem pois dificulta seu uso.

\subsubsection{Modelo de Gordon}

O clássico Modelo de Gordon de 1962 é outra forma de se avaliar o preço de uma ação. Conforme Damodaran (2005), o modelo básico para avaliar o patrimônio líquido é o de desconto de dividendos, também conhecido por Modelo de Gordon. Nele o valor de uma ação é o valor presente nos dividendos que se espera que ela gere. (LIMA, 2007). O modelo expressa o valor de uma ação como o valor presente de todos os dividendos futuros previstos pagos pela empresa a seus acionistas. (BREALEY et al., 2002).

Segundo Damodaran (2005), o MDD é calculado por:

$$
\text { Valor da ação }=\sum_{t=1}^{n} \frac{d p s_{t}}{(r-g)^{t}}
$$

em que:

dps $=$ dividendos esperados daqui a 1 ano;

$(\mathrm{r})=$ taxa exigida de retorno para o Capital Próprio;

$(\mathrm{g})=$ taxa de crescimento perpétua de dividendos.

No entanto, segundo Damodaran (2005) e Martins et al. (2001), o Modelo de Gordon apresenta alguns problemas. De acordo com os autores, a grande dificuldade está na questão da definição de qual será a taxa de crescimento dos dividendos futuros (g), pois, à medida que 
a taxa de crescimento converge para a taxa de desconto, o valor vai para infinito, invalidando seu resultado. Para eles, o Modelo de Gordon é uma forma simplista de avaliar ações, extremamente sensível aos dados relativos à taxa de crescimento. Damodaran (1994) aponta que esse modelo estaria restrito somente às empresas que tenham: taxa de crescimento comparável ou inferior à taxa nominal de crescimento da economia, para que não ocorram resultados tendendo a infinito; políticas de pagamento de dividendos em relação aos lucros bem estabelecidos, para que seja possível estipular dividendos futuros e que pretendam continuar a executá-las no futuro.

De acordo com Martins et. Al. (2006, 139) Gordon e Gordon (1997) tentaram contornar essa deficiência do modelo

$$
\text { Valor da ação }=\sum_{t=1}^{n} \frac{d p s_{t}}{(r-g)^{t}}+\frac{e p s_{t+1}}{r(1-r)^{t+1}}
$$

em que:

(r) = taxa exigida de retorno para o Capital Próprio;

$(\mathrm{t})=$ é o número de períodos para o qual se espera crescimento anormal

$e p s_{t+1}=$ é igual ao lucro por ação no período $\mathrm{t}+1$, período no qual a empresa deixa de ter lucros anormais

Gordon e Gordon (1997) sugere que o horizonte de tempo pode seguir o que os analistas normalmente utilizam que é cerca de 5 anos e que um período entre 5 a 10 anos seria razoável.

Há dois dados básicos para o modelo: os dividendos esperados e a taxa de retorno exigida sobre o patrimônio líquido. Para obter os dividendos esperados são traçadas hipóteses sobre as futuras taxas de crescimento dos lucros contábeis e índices payouts (pagamentos de dividendos). Já a taxa exigida corresponde ao retorno calculado pelo CAPM já descrito em tópicos anteriores. Segundo Damodaran (1994), os dividendos estão ligados de maneira bem próxima aos lucros contábeis, pois são, por teoria, uma parcela ou função do desempenho da empresa em um período, o qual é apontado pelo lucro.

Dessa maneira, pode-se constatar que o Modelo de Gordon, também, leva à compreensão de variáveis contábeis na precificação do valor da empresa. 


\title{
2.3.4 Value Relevance
}

Inspirados nas Teorias de EMH, CAPM e Information Approach, a partir da segunda metade do século passado surgiram vários estudos que tratam da relevância da informação contábil nos preços das ações: os estudos em value relevance.

Os estudos de value relevance concentram-se na relação empírica entre o valor de mercado das ações (ou mudanças nos valores) e dados contábeis. (ODA et al., 2004). Sua finalidade é entender e verificar o poder explanatório das variáveis contábeis na avaliação de empresas. (CUPERTINO, 2003).

Lopes e Martins (2005, p. 77) explicam que

\begin{abstract}
Dentro do paradigma positivo, a relação entre a informação contábil e o preço dos títulos negociados em bolsas de valores é central. Isso porque os preços de mercado refletem as expectativas dos agentes econômicos acerca do futuro da empresa e da economia. Dessa forma, a relação entre a informação emanada da contabilidade e esses preços indica que as expectativas dos agentes estão sendo alteradas. Esse processo sinaliza que os números contábeis refletem um conteúdo informativo que o mercado ainda não possui.
\end{abstract}

Dessa forma, esses estudos verificam o poder informativo que a contabilidade possui com relação aos preços das ações. Dizer que uma determinada variável contábil possui value relevance, em um mercado, significa dizer que a essa variável tem o poder de alterar o preço das ações.

No final da década de 90 e início de 2000, diversos estudos internacionais têm sido realizados com o objetivo de avaliar a relevância das informações sobre fluxos de caixa para o Mercado de Capitais. (MALACRIDA et al., 2008).

Holthausen e Watts (2001) classificaram esses estudos em três categorias:

1. Estudos de Associação Relativa: comparam a associação entre o preço das ações (ou retornos) e valores contábeis calculados por novos padrões propostos em relação aos valores de padrões existentes. Em geral, concluem que a prática contábil com maior $\mathrm{R}^{2}$ é mais value relevant; 
2. Estudos de Associação Incremental: verificam se determinadas práticas contábeis são úteis em explicar o valor (ou retorno) das ações (coeficientes diferentes de zero). As diferenças entre valores estimados e previstos são, geralmente, interpretadas como evidências de erro de mensuração nos números contábeis (nível de confiabilidade);

3. Estudos de Conteúdo Informacional Marginal: verificam se um valor contábil específico adiciona informação para um grupo de investidores (short window studies).

Iudícibus e Lopes (2004) sugerem, para o Brasil, outra taxonomia para os estudos em value relevance:

1. Novas Informações: estudos que analisam a reação do mercado às novas informações contábeis e a importância da informação contábil para o mercado;

2. Nível de Relacionamento: estudos que buscam apresentar alterações no comportamento do relacionamento entre o retorno das ações e os números contábeis;

3. Não Financeiras: estudos que avaliam a relevância da informação contábil comparada com informações não financeiras.

Coutinho et al. (2007, p. 6) explicam que, dos estudos no exterior analisados, foram constatados que $94 \%$ estão concentrados em estudos de associação relativa e incremental.

$\mathrm{O}$ enfoque de value relevance requer que se identifique um item contábil, bem como uma função de avaliação que consiga delinear esse item dentro do preço de ações. (CUPERTINO, 2003). Nesse âmbito, são estudadas diversas variáveis como: lucro; fluxo de caixa; patrimônio líquido; passivo; entre outras. Observe-se que os estudos se concentram em analisar a reação dos preços dos títulos, sobretudo das ações, a essas informações.

Nesse contexto, o lucro contábil é, dentre as demais variáveis, uma das mais estudadas. Isso ocorre, pois, segundo Cunha e Lustosa (2007), é tido como a principal variável contábil para expressar o desempenho da empresa e a que resume melhor as variações de preços das ações.

O trabalho seminal An Empirical Evaluating of Accounting Income Numbers, realizado por Ray Ball e Phillip Brown (1968), inaugurou uma série de estudos da relação entre a informação contábil e o mercado de capitais. De modo geral, o que se pode antecipar é que, 
apesar de não se ter uma relação forte entre variáveis contábeis e o preço da ação, a variável contábil parece ser relevante para investidores de mercado de capitais e o mercado é eficiente com respeito à informação contábil. (LOPES, 2002).

Nos próximos tópicos, serão apresentados os resultados de vários estudos realizados no exterior e, na sequência, os resultados obtidos dessa relação no Brasil.

\subsection{Estudos sobre informação contábil e o mercado de capitais}

Retomando a taxonomia realizada por Kothari (2001), as chamadas capital market research (pesquisas em mercados de capitais) podem ser divididas em seis grande linhas, segundo o autor: análise fundamentalista e avaliação; value relevance; relação de impostos e mercados de capitais; testes de eficiência de mercado; papel da contabilidade em contratos e no processo político; regulação da evidenciação (disclosure). Como já fora mencionado, o objetivo deste estudo é concentrado e permeia as linhas de análise fundamentalista e avaliação e value relevance.

Lopes (2002), ao estudar a relação entre a informação contábil e o mercado de capitais, faz, ainda, mais uma abertura para os estudos sobre análise fundamentalista e avaliação e value relevance nas seguintes categorias de estudo, de acordo com seu tema de investigação central:

- $\quad$ timeliness do resultado;

- $\quad$ conteúdo informativo do resultado;

- $\quad$ resultado, fluxo de caixa, accruals;

- $\quad$ volatilidade do resultado e risco sistemático.

Dentre as categorias apresentadas por Lopes (2002), o presente estudo encontra-se entre aquelas que pretendem investigar a relação entre a Volatilidade do Resultado e Risco Sistemático. Segundo Lopes e Martins (2005), o número de estudos sobre essa relação ainda é considerado restrito, tanto na literatura internacional e ainda mais no Brasil. 
Assim, estudos sobre Value Relevance e Análise Fundamentalista e Valuation são o pano de fundo deste estudo e os que investigam a Volatilidade do Resultado e Risco Sistemático são a linha-mestra em que se encontra este trabalho.

No próximo tópico, serão apresentados os principais estudos realizados no exterior e no Brasil sobre Value Relevance e Análise Fundamentalista e Valuation. Na sequência, serão apresentados e detalhados todos os estudos sobre Volatilidade do Resultado e Risco Sistemático encontrados por esta revisão.

\subsubsection{Estudos sobre análise fundamentalista e value relevance}

Ball e Brown, em 1968, em seu artigo seminal "An empirical evaluation of accounting income", foram os primeiros a introduzir pesquisas entre a informação contábil e o mercado de capitais. Observando a relação entre o sinal (direção) dos lucros anormais e os retornos anormais das ações negociadas na Bolsa de Nova York, encontraram evidências sobre a relevância das demonstrações contábeis divulgadas para os investidores.

Os autores avaliaram o conteúdo informacional dos relatórios anuais da contabilidade de 261 empresas, com demonstrações publicadas entre 1957 e 1965, para testar se o lucro contábil reflete apenas fatores já incorporados aos preços das ações ou se agrega valor informativo para o mercado de capitais. Buscaram responder a essa pergunta por meio da relação entre os lucros anormais apresentados e a variação positiva anormal nas taxas de retorno das ações. (IUDÍCIBUS; LOPES, 2004). O lucro anormal foi calculado pela diferença entre o lucro contábil e o lucro da regressão (erro da regressão). Os resultados mostraram as alterações anormais nos preços das ações, acima de 1 para empresas que anunciaram lucro maior que o previsto e abaixo de 1 para empresas com lucros menores que o previsto.Também foi observado que, na data do anúncio, grande parte do retorno já ocorreu e existe uma reação do preço após ele: 10 a 15\% da informação ocorre após o anúncio e 90 a $85 \%$ ocorre por antecipação da informação contábil, além disso, na data do evento foram encontrados retornos anormais de $7,5 \%$.

Seus resultados, disseram essencialmente que os preços de títulos variam na mesma direção dos lucros contábeis. Isso pode estar ocorrendo porque os títulos estão reagindo aos mesmos eventos que os lucros, ou pode estar ocorrendo que os lucros transmitam informação ao mercado de títulos. 
No mínimo, o mercado se comporta como se os lucros contivessem informação. (HENDRIKSEN; VAN BREDA, 1999, p. 206).

Beaver (1968) estudou a reação do volume negociado ante as datas dos anúncios e percebeu que tanto o preço quanto o volume reagem fortemente à informação contábil na data do evento. Assim como eles, Beaver (1998), Brown e Kenely (1972), Foster (1977), Morse (1981), mediante estudos de eventos, chegaram à conclusão de que o resultado contábil fornece informações ao valor da empresa, ratificando a importância da informação contábil para o mercado.

Os estudos mostraram que somente $10 \%$ do resultado anormal ocorre no mês do anúncio, refletindo que os preços são afetados por fontes de informações mais atualizadas que os resultados. Entretanto, Beaver (1968) e Foster (1986) encontraram grandes respostas à informação contábil na semana, dia e hora do anúncio, ou seja, há timeliness do resultado.

O conteúdo informativo do lucro (resultado) ou a magnitude do impacto da contabilidade no mercado, foi estudado por Beaver et al. (1979). Esses autores estudaram a relação entre alterações residuais nos lucros e nos preços e concluíram que elas são correlacionadas. No entanto, essa relação aparece fraca e instável, pois os lucros são compostos parte por caixa e parte por accrual e a antecipação das informações pelo mercado acabam por reduzir essa relação. (IUDÍCIBUS; LOPES, 2004). Há conclusões de que existe uma relação entre lucros e preços, porém isso não se dá de 1:1 e de que a relação entre lucros e retornos sofre alterações no decorrer dos anos e é diferente de empresa para empresa foram encontradas por Beaver et al. (1980).

Nessa associação entre alterações residuais nos lucros e nos preços, o coeficiente angular da regressão, também chamado de coeficiente de resposta nos preços, (ERC - Earnings Response Coefficient) tem sido bastante estudado. Trabalhos de Collins et al. (1997), Collins e Kothari (1989), Hayn (1995) e Komerdi e Lipe (1987) demonstram que esse coeficiente será maior ou menor dependendo do tamanho da empresa, nível de crescimento e taxa de juros.

Os componentes dos lucros foram estudados por Bernard e Stober (1989) e Strong e Walker (1993). Os resultados mostraram-se contraditórios, afirmando ou não que o fluxo de caixa possui poder de informação incremental. O que se sabe é que esse poder varia de acordo com 
condições gerais da economia. Além disso, esses estudos sugerem que o mercado reconhece a parcela do lucro que é transitória.

Uma grande gama de estudos centraram-se no poder de explicação do patrimônio líquido. Após os trabalhos de Feltham e Ohlson (1995) e Ohlson (1995) muitos estudos começaram a explicar o comportamento dos preços em função de números de balanço. Os resultados a que chegam os autores são que demonstrações ajustadas à inflação não fornecem informações adicionais; que para empresas com grande quantidade de ativos intangíveis, lucros e valores de balanço não são relevantes; que prejuízos impactam menos nos preços que resultados positivos; que valor do patrimônio possui mais relevância do que resultado em empresas ou com saúde financeira debilitada ou, ainda, com baixa persistência dos lucros. (BARTH et al.,1993; COLLINS et al., 1997; HAYN, 1995; LEV, 1997).

Por fim, outros estudos, seguindo a ideia de que a variação do preço das ações e, consequentemente, o preço dos ativos são funções do risco sistemático (beta), como os de Beaver et al. (1970; 1979) e Beaver e Manegold (1975) mostram que medidas de volatilidade do lucro contábil são correlacionadas positivamente com o beta das ações das empresas. Esses estudos buscaram associar medidas de risco de mercado com as variáveis contábeis, visando verificar se a contabilidade ameniza o impacto das flutuações reais na economia ou se reflete essas flutuações de forma integral. É nessa linha em que o presente estudo se encaixa.

Pesquisas recentes, de Amir et al. (1993), Barth e Clinch (1993), Chan e Seow (1996), Elgers e Rees (1997) e Pope e Ress (1992) investigaram o conteúdo informacional das demonstrações contábeis em outros GAAPs. Observaram que as empresas participantes de mercados estrangeiros, ao "reelaborarem" suas demonstrações contábeis de acordo com outros GAAPs, fornecem informações relevantes capazes de impactar no preço dos ativos no mercado de ações. Os resultados encontrados apresentam-se, ainda, contraditórios. (MEEK; THOMAS, p. 2004).

Assim sendo, no exterior, a relação lucro preço tem sido exaustivamente estudada nos últimos 30 anos e importantes revisões e investigações da importância desses estudos foram feitas também por Beaver (1998), Dechow (1994), Holthausen e Watts (2001); Kothari (2001); Lev (1989); Nichols e Wahlen (2004). Resumidamente, segundo Beaver (1998), pode-se chegar a algumas conclusões: 
1 Existe uma forte correlação positiva entre a variação nos preços e nos lucros das empresas em períodos concomitantes.

2 Essa relação não ocorre na base de 1:1 porque o mercado reage a itens transitórios.

3 O preço parece antecipar o comportamento do lucro no preço das ações devido a informações mais rápidas que a contabilidade.

4 Esse reconhecimento atrasado ocorre para lucro e patrimônio.

5 O preço das ações comporta-se como se houvesse reconhecimento assimétrico de informações econômicas pela contabilidade, ou seja, há conservadorismo.

6 O preço das ações pode ser usado para prever o lucro das empresas correspondentes.

7 Os preços das ações parecem considerar tanto fluxo de caixa como o accrual do preço das ações.

8 O patrimônio e o lucro são importantes para explicar o comportamento dos preços das ações.

9 De acordo com a sofisticação do mercado ele utilizará ou não informações off-balance sheet.

10 Componentes discricionários são avaliados diferentemente dos não discricionários.

11 Medidas de risco sistemático, nos preços, são correlacionadas com medidas no risco sistemático do lucro contábil.

Assim, com base nos estudos mencionados, de modo geral o que se vê é que, apesar de não se ter uma relação forte entre variáveis contábeis e o preço da ação, a variável contábil parece ser relevante para investidores de mercado de capitais e o mercado é eficiente com respeito à informação contábil. (LOPES, 2002).

\subsubsection{Estudos sobre análise fundamentalista e value relevance no Brasil}

No Brasil, a pesquisa em mercado de capitais é bem mais recente do que nos países mais desenvolvidos, especialmente nos Estados Unidos. Foi nos últimos anos que se observou um aumento de estudos nessa área do conhecimento contábil.

Os estudos que analisam a reação do mercado às novas informações contábeis e a importância dessa informação utilizam, em sua maioria, a ferramenta de estudos de eventos. Segundo Lima e Terra (2004), um dos primeiros a estudar a importância da informação contábil no Brasil foi Schiehll (1996). Ele investigou, por intermédio de um estudo de eventos no 
mercado brasileiro de ações, se a divulgação das demonstrações financeiras anuais e trimestrais das empresas de capital aberto produz efeitos no comportamento do preço de suas ações. Os resultados empíricos evidenciaram que o evento da divulgação é relevante no mercado de capitais e produz efeitos significativos sobre o comportamento dos preços das ações.

Depois dele, Prux Jr. (1998) analisou se a divulgação das demonstrações contábeis, em moeda constante das empresas de capital aberto com ações negociadas na Bovespa, produz efeitos no comportamento do preço das ações. Os resultados empíricos evidenciaram efeitos significativos das divulgações sobre os preços das ações, reforçando a ideia de value relevance.

Lima e Terra (2004) observaram na Bovespa, no período de 1995 a 2002, se os preços das ações das empresas negociadas no mercado acionário brasileiro não reagem (não antecipam e não variam na mesma direção) aos resultados contábeis divulgados, sendo eles lucros ou prejuízos. Constataram que o mercado de capitais brasileiro não se surpreendeu com a divulgação das demonstrações financeiras das empresas selecionadas na "Amostra Total". Entretanto, para a amostra de empresas que tiveram lucros e das empresas que tiveram prejuízos, foram encontrados retornos anormais significativos na data de divulgação das demonstrações financeiras. O resultado apresentou coerência da reação: para a subamostra "Lucros", a reação foi positiva, gerando retornos anormais positivos e significativos. Para a subamostra "Prejuízos", a reação foi negativa, gerando retornos anormais negativos e significativos.

Em um segundo estudo, os mesmos autores estudaram para o mesmo período, o efeito dos anúncios de demonstrações contábeis das empresas em geral e aquelas com sinalizadores diferenciados de boas práticas de governança corporativa. O resultado mostrou que os investidores reagem de forma diferenciada a alguns sinalizadores de boas práticas de governança corporativa das empresas. Foi possível perceber retornos anormais significativos apenas em duas subamostras (empresas pontuais na divulgação das suas demonstrações financeiras e empresas privadas) em relação aos seus pares (empresas que atrasaram a divulgação das suas demonstrações financeiras e empresas estatais). 
Sarlo Neto et al. (2004) observaram a mesma questão que Lima e Terra (2004), verificando como reagiriam duas subamostras, as de empresas ordinárias e as preferenciais. Pesquisaram entre os anos de 1990 a 2002 e seus resultados mostraram que:

- Ordinárias: constatou-se que a informação contábil é importante somente nos casos de lucros anormais negativos, indicando que para os casos de lucros anormais positivos, as informações contábeis divulgadas perdem relevância diante de outras fontes de informações.

- Preferenciais: constatou-se que, enquanto os retornos anormais negativos antecipam os resultados a serem divulgados, os retornos anormais positivos variam praticamente no momento da divulgação do resultado.

Neste trabalho, pode ser observado que para as ações preferenciais o mercado apresenta-se eficiente na forma semiforte. Em relação às ações ordinárias, a eficiência não se apresenta de forma consistente, pois é válida somente para os resultados negativos. Em relação às ações preferenciais, as evidências indicam uma posição conservadora do mercado em relação à divulgação das informações contábeis. O mercado antecipa e reflete, por meio dos preços, os eventos negativos. No entanto, quando os eventos são positivos, os preços só refletem esse fato em momentos próximos ou posteriores à sua divulgação.

Cunha e Lustosa (2007) observaram, de 2004 a 2005, 20 empresas dos setores de metalurgia e siderurgia com relação ao efeito das notícias divulgadas publicamente entre o encerramento do trimestre e a data de divulgação. O resultado mostrou que o mercado reage a essas notícias e essa possa, talvez, ser a causa de baixa reação no momento de divulgação dos lucros.

Rezende et al. (2008) estudaram, entre 1996 e 2007, a relevância da informação contábil em "custo histórico" e em "moeda constante" de empresas brasileiras de capital aberto, ou seja, se as demonstrações realizadas por correção de inflação e por custo histórico teriam diferenças de value relevance. No entanto, a diferença encontrada foi contrária ao esperado, ou seja, as informações contábeis em custo histórico são mais relevantes, ao passo que as informações corrigidas não apresentaram relevância informacional, não possibilitando comparações entre os valores dos $\mathrm{R}^{2}$ calculados. 
Gomes e Loriato (2006) observaram value relevance por meio do volume de negócios de 41 ações no período de 01/01/2000 a 31/12/2004. Os resultados encontrados mostram que as divulgações contábeis anuais trazem informações relevantes para o mercado brasileiro provocando um aumento no volume de ações negociadas, especialmente no entorno da semana do anúncio. Isso coincide com a teoria dos mercados eficientes na forma semiforte, ressalvado o tratamento para volumes de negócios e não para preços como trata a teoria. Os resultados encontrados também mostram uma movimentação de negócios umas sete ou oito semanas antes das divulgações contábeis anuais. Isso é possível pela pouca pulverização do mercado acionário, que permite que os detentores do controle acionário tenham acesso às informações bem antes da divulgação.

Mais recentemente, Santos (2008) estudou a associação dos preços de mercado aos componentes do lucro contábil no período de junho de 2000 a junho de 2007, com observações trimestrais. Foi observada, por meio de dados em painel, a relação entre os preços e as receitas e despesas. Os resultados foram totalmente contrários à teoria. Evidenciaram uma relação negativa para a variável receita, consubstanciada no coeficiente negativo apresentado nas equações obtidas mediante a análise de dados em painel, pelo modelo de efeitos constantes e efeitos fixos. Além disso, esse coeficiente não se mostrou significativo estatisticamente. A variável despesa apresentou coeficientes positivos e estatisticamente significantes para explicar os retornos anormais. O modelo de efeitos aleatórios não apresentou resultados significativos para ambas as variáveis.

Scarpin et al. (2007) pesquisaram, no ano de 2005, qual a reação das divulgações contábeis três semanas antes e depois da sua divulgação. Os resultados mostraram que a data de publicação das ações impacta no retorno das ações, causando diferenças no preço e no volume de negócios.

Sarlo Neto et al. (2006) investigaram se tipo de ação, regulamentação, controle acionário e liquidez poderiam indicar maior ou menor value relevance. A amostra pesquisada foi composta por ações negociadas na BM\&FBOVESPA (BOVESPA), durante o período de 1995 a 2002. Os resultados encontrados indicaram que as médias dos retornos anormais são sensíveis às características do controle acionário e liquidez. 
Martinez (2004) analisou o período de estudo de 1996 a 2003, focalizando as companhias abertas brasileiras. A partir de informações extraídas do sistema I/B/E/S, utilizou a previsão de resultados do consenso dos analistas como proxy para as expectativas do mercado. As análises efetuadas, no artigo, indicaram as seguintes conclusões: predominam quantitativamente as surpresas negativas e essas parecem que já são conhecidas pelo mercado antes mesmo do anúncio do resultado, pois as maiores quedas de retornos acumulados ocorrem antes mesmo do anúncio. Já surpresas positivas, de modo geral, marcam o início de um ciclo de retornos positivos. Somado a isso, o mercado tem pago um prêmio para as empresas que conseguem atingir, com relativa precisão, as estimativas dos analistas. $\mathrm{O}$ retorno dessas empresas num período de 30 dias é maior que o das empresas que excedem, com folgas, as expectativas dos analistas.

Nascimento et al. (2007) investigaram o impacto da divulgação do resultado contábil em USGAAP no preço das ações das companhias abertas brasileiras participantes do programas de ADRs no período de 1999 a 2004 por meio de um estudo de evento. Os resultados encontrados apontam que o resultado contábil elaborado de acordo com os princípios norteamericanos não representa informação relevante para o mercado brasileiro. Os relatórios em US-GAAP não mais impactariam no mercado, devido ao GAAP nacional já ter refletido a provável surpresa. Constatou-se, assim, que as demonstrações contábeis realizadas conforme as PCAB seriam suficientes para a avaliação dos usuários externos.

Esse resultado aproxima-se do encontrado por Costa (2007), em que os ajustes aos US-GAAP no Lucro não se apresentam como informação relevante para o mercado brasileiro. Isso porque parte delas estaria antecipada no resultado divulgado no Brasil, até abril.

Outros estudos testaram a relevância da informação contábil por intermédio da mensuração do nível de associação entre o retorno contábil mediante o lucro e o retorno da ação. Centraram a questão do modelo de avaliação e qual deles teria maior aderência no mercado brasileiro.

Lopes (2001) testou a relevância da informação contábil, por meio do modelo de Ohlson (1995). Em relação ao modelo de Ohlson (1995), o estudo realizado no Brasil por Lopes (2002) demonstrou existir aderência do modelo, para os dados brasileiros. Chama a atenção o fato de, no caso brasileiro, o poder explicativo estar concentrado no patrimônio líquido e não no valor dos resultados anormais futuros. Lopes e Martins (2005, p.168) afirmam ainda que: “esse resultado confirma a superioridade das informações advindas do balanço, sobre aquelas 
da demonstração do resultado do exercício para empresas que reportam suas informações de acordo com as normas contábeis presentes no Brasil."

Mais recentemente, Lopes e Galdi (2006) verificaram a relevância da informação a partir da proposta de Piotroski (2000). O modelo R_score de Piotroski (2000) foi adaptado para a realidade brasileira e os resultados encontrados evidenciam que o R_score formulado com os dados contábeis pode, estatisticamente, explicar a variação dos títulos, tendo maior poder explicativo concentrado nos níveis de endividamento (delta lever).

Werneck et al.(2007) estudaram qual dos dois modelos, Ohlson (1995) e a proposta de R_score formulada por Piotroski (2000), têm maior poder de previsão de retorno anormal futuro. Os resultados mostraram aderência de ambos os modelos, entretanto, não se pode afirmar a predominância ou superioridade entre eles.

Cupertino (2003) compara modelos de avaliação de empresas teoricamente equivalentes, utilizando dados do período de 1995 a 2004 de firmas brasileiras, com o objetivo de identificar o poder de explicação das previsões obtidas em cada enfoque. Seu estudo conclui que o modelo de fluxo de caixa apresenta a maior acurácia e poder explanatório em relação aos outros modelos (dividendos e lucro residual), assim como o maior número de estimativas consideradas razoáveis. A constatação segue uma direção divergente da conclusão de que o lucro residual é o modelo dominante, verificada em alguns estudos estrangeiros.

Outros estudos observaram lucros e outros indicadores de desempenho. Cunha e Lustosa (2007) estudaram as empresas abertas brasileiras entre os anos de 1995 e 2004, verificando se haveria maior relação entre o retorno das ações e o lucro contábil do que entre esse mesmo retorno e o fluxo de caixa das operações, em intervalos pequenos e maiores de tempo. Os resultados indicam que o lucro contábil aparece como melhor medida de desempenho em períodos trimestrais, mas, ao se prolongar o intervalo de tempo analisado (anual), o fluxo de caixa das operações apresenta maior relação com o retorno das ações.

Malacrida et al. (2008) observaram a relevância do lucro contábil e do fluxo de caixa. A hipótese de pesquisa foi de que o lucro possui capacidade de predizer os fluxos de caixa operacionais futuros maior do que o fluxo de caixa operacional. Para isso, utilizou o modelo Piotroski (2000) adaptado por Lopes e Galdi (2006) e o modelo de Ohlson (1995). A pesquisa 
empírica foi desenvolvida a partir das demonstrações de fluxo de caixa publicadas de 29 empresas brasileiras com ADRs, no período de 1999 a 2005. Os resultados encontrados indicam que: (1) fluxo de caixa operacional corrente possui capacidade preditiva maior que a do lucro; (2) a desagregação do lucro corrente em fluxo de caixa operacional e accruals agregados indica que accruals possuem capacidade preditiva adicional ao fluxo de caixa operacional corrente; (3) lucro corrente desagregado em fluxo de caixa operacional e vários componentes de accruals possuem maior capacidade preditiva do fluxo de caixa operacional futuro do que o modelo de accruals agregados. Assim, os resultados evidenciaram que a demonstração do fluxo de caixa fornece informações adicionais relevantes em relação àquelas fornecidas pelo lucro na predição dos fluxos de caixa operacionais futuros das empresas, indicando a rejeição da hipótese de pesquisa de que o lucro possui capacidade preditiva maior do que o fluxo de caixa.

Lima et al. (2004) verificaram o impacto do indicador EBITDA nos Retornos Totais aos Acionistas, no período compreendido entre 1994 e 1999, nas empresas com ações negociadas na BM\&FBOVESPA (BOVESPA) classificadas no ranking GVA-50. Os resultados empíricos geraram evidências de que a relação do indicador EBITDA com os retornos apresenta um grau de correlação que não é tão significativo para afirmar que os retornos totais aos acionistas variam de forma proporcional à variação do EBITDA.

Okimura e Sousa (2004) estudaram, entre os anos de 1997 e 2003, a associação das métricas EVA e o lucro líquido em relação ao retorno das ações das companhias abertas brasileiras. Os resultados indicaram uma superioridade do EVA ${ }_{\circledast}$ na associação com o retorno das ações para todas as especificações testadas, sugerindo que as medidas de desempenho, levando em conta o custo de oportunidade dos recursos investidos na companhia por credores e acionistas, fornecem uma melhor predição do retorno das ações do que as métricas baseadas em dados contábeis. O fluxo de caixa operacional mostrou-se a segunda medida de desempenho mais relevante para explicar o retorno das ações, ficando o Lucro Líquido em terceiro lugar.

Dessa forma, no Brasil, os estudos trataram da relação entre números contábeis e o preço das ações e encontraram:

- $\quad$ evidências de eficiência de mercado em sua forma semiforte; 
- $\quad$ as informações divulgadas pela contabilidade impactam no preço das ações e o volume de negócios, porém em proporções menores do que em mercados como o americano;

- a relevância da informação contábil é impactada pelo tipo de ação, ordinárias ou preferenciais, controle acionário e nível de liquidez;

- não é impactada pelo nível de governança, publicações em outros GAAPs, nível de participação da empresa no mercado, tipo de ação ou regulamentação;

- quanto aos indicadores de desempenho e o mercado de capitais foi contatado que:

○ patrimônio líquido possui poder explicativo;

- lucro contábil é relevante para períodos curtos;

○ $\quad$ fluxo de caixa é mais importante em períodos longos;

- lucros desagregados em fluxo de caixa e accruals decompostos possuem maior associação com retornos do que fluxo de caixa ou lucro contábil;

○ $\quad$ EBITDA não apresentou associação com retornos das ações e

○ $\quad$ EVA apresentou maior associação que lucros contábeis.

Dessa maneira, os estudos que analisam a informação contábil e sua associação com os retornos nas ações não apresentaram, ainda, resultados consensuais. Percebe-se que, apesar não haver evidências claras da magnitude da associação entre informações contábeis e o preço das ações, há evidências de que a variável contábil parece ser relevante para investidores de mercado de capitais e o mercado é eficiente com respeito à informação contábil. (LOPES, 2002).

\subsubsection{Informação contábil e o risco sistemático}

Como o objetivo deste estudo foi identificar se os betas contábeis de uma empresa possuem relação com seu risco sistemático, foi necessário levantar os estudos que avaliavam a relação entre informações contábeis e seu risco sistemático. Os estudos encontrados, em sua maioria, usam como proxy do risco sistemático, o beta de mercado. Já como proxy para a informação contábil são usados, muitas vezes, variáveis contábeis e ou o beta contábil.

Nessa categoria de estudos, em 1969, os pioneiros foram novamente Ball e Brown; em seu artigo, nomeado "Portfolio Theory and Accounting", examinaram a habilidade dos números 
contábeis em refletir informação sobre o risco da empresa. Mais precisamente, testaram “empiricamente a intensidade segundo a qual os números contábeis são sensíveis ao risco conjuntural da empresa". (BALL; BROWN, 1969, p. 314). Segundo os autores, um problema encontrado no desenho de um teste desse tipo é a necessidade de estimar retornos esperados, sendo que só é possível medir retornos históricos. Uma possibilidade é assumir que: (a) o beta é estável ao longo do tempo e (b) a relação é idêntica tanto para retornos ex ante e retornos ex post (p. 315). O teste consistiu em uma análise da associação entre medidas de movimentação conjunta de taxas de retorno ex post de ações e lucros contábeis.

Aplicaram regressão em 261 empresas, entre 1946 e 1966, e observaram a relação do lucro líquido, lucro operacional e lucro por ação com o risco da empresa. Os resultados mostram que o movimento conjunto dos lucros contábeis em relação ao lucro do mercado prevê, moderadamente bem, o grau de associação entre os retornos das ações da empresa e o retorno do mercado, mostrando que eles são ainda melhores preditores do risco conjuntural. Os resultados indicam, também, que as variações (primeiras diferenças) dos lucros são, aparentemente, especificações mais apropriadas do que os níveis absolutos nesses modelos de estimação. De um modo geral, as relações entre os três tipos de lucro explicam de $35 \%$ a $40 \%$ da variação no risco sistemático.

Na sequência, Beaver et al. (1970) identificaram se variáveis contábeis como o percentual dos dividendos pagos, crescimento, alavancagem, liquidez, tamanho, variabilidade dos lucros e beta contábil possam ser vistas como um substituto do retorno de mercado. Baseado em uma amostra de 307 empresas cujas demonstrações financeiras do período de 1947 a 1965 estavam disponíveis no Compustat Industrial Tape e cujos dados sobre dividendos e preços das ações estivessem no Center for Research in Security Prices (CRSP), que contém informações mensais dos preços de todas as ações ordinárias listadas na Bolsa de Valores de Nova Iorque (NYSE) desde janeiro de 1926 até junho de 1966.

A medida de risco de mercado escolhida foi o beta das ações ordinárias, estimado por meio da seguinte regressão linear, utilizando o método de mínimos quadrados ordinários.

$$
r_{i t}=a_{i}+b_{i} r_{m t}+e_{i t}
$$

em que: 
$r_{i t}=$ taxa de retorno da ação da empresa i durante o período t, ajustada por dividendos e outros proventos (splits, bonificações etc.) e assumindo-se capitalização;

$r_{m t}=$ taxa de retorno do índice Fisher's link relative durante o período t, assumindo-se capitalização contínua. Os autores justificam a sua escolha por ser o único disponível de 1947 a 1965 que inclui todas as empresas negociadas na NYSE e que trata corretamente os dividendos. Alegam, também, que Fama et al. (1973) e Fisher (1970) mostram que esse índice tem alta correlação com os índices da Standard \& Poor's e Dow Jones;

$b_{i}=$ estimativa empírica do risco sistemático $\beta \mathrm{i}$. Foram feitas regressões individuais para cada ativo em cada subperíodo, totalizando 614 regressões para as 307 empresas que compõem a amostra analisada.

O estudo demonstrou que as variáveis que mais se relacionaram com o beta de mercado foram: a variabilidade dos lucros, o payout médio, o beta contábil e o endividamento. Os autores constataram o poder de explicação dessas variáveis de $23 \%$ a $44 \%$ no beta de mercado.

Uma discrepância relevante dos resultados desse estudo em relação ao de Ball e Brown (1969) é que, embora Beaver et al. (1970) não tenham apresentado os resultados, eles afirmam que a utilização de diferenças de primeira ordem no retorno contábil para o cálculo do beta contábil apresentou resultados consistentemente mais pobres do que a utilização do retorno contábil em si, contrariando totalmente os resultados de Ball e Brown (1969) nas quais as séries de diferenças de lucros sempre apresentaram poder explicatório maior que a série dos próprios lucros.

Hamada (1971) investigou, em um estudo consagrado entre as pesquisas de finanças, por meio de 304 empresas entre os anos de 1848 e 1967, a relação entre as finanças corporativas e análise de portfólio. $\mathrm{O}$ estudo investigou a relação entre alavancagem e o efeito produzido no risco sistemático das ações preferenciais. O autor concluiu que existe influência da alavancagem financeira das firmas no risco sistemático e mostra, mediante expressão matemática, que é possível estimar esse efeito. Terminou por propor o cálculo do beta da empresa com base no beta de mercado multiplicado pelo endividamento e dividido pelo valor de mercado da empresa. 
Em 1972, Pettit e Westerfield buscaram estudar os fatores que previam o coeficiente beta dos ativos. Aplicaram a uma amostra de 313 empresas norte-americanas no período de junho de 1947 a junho de 1968. Os fatores utilizados para decompor o retorno dos ativos foram: a variação dos fluxos de caixa esperados e a variação na taxa de desconto dos fluxos. De acordo com os autores, o CAPM pressupõe que o coeficiente da variação dos fluxos seja de mesma magnitude e peso que o da variação da taxa, sendo um caso muito específico para ser amplamente utilizado sem incorrer em erros. Observaram um alto grau de correlação entre o beta dos fluxos de caixa e os betas das taxas. Buscaram um aprofundamento dos determinantes do beta, comparando a habilidade do modelo por eles proposto com o modelo tradicional para estimação do beta. Observaram que as predições feitas, por intermédio do modelo por eles proposto, conseguiram maior poder explicativo que o modelo tradicional. (ODA, 2004).

Gonedes (1973) examinou se nos dois estudos anteriores, Ball e Brown (1969) e Beaver et al. (1970), a associação entre a o risco baseado no mercado e o risco baseado em informações contábeis era válido. Mediante regressão de 99 empresas, encontrou uma relação significativa, porém com baixo $\mathrm{R}^{2}$. Encontrou uma relação estatisticamente significante entre as estimativas de risco sistemático baseadas em dados de mercado e as baseadas em dados contábeis apenas na situação em que as estimativas contábeis foram ajustadas por valores de mercado.

Já Rosenberg e Mckibben (1973) montaram um modelo com variáveis contábeis e beta histórico que explicou 38\% da variação do mercado. Combinaram o histórico de preços das ações e dados contábeis para fazerem previsões sobre a distribuição de retornos para 571 empresas com informações disponíveis na COMPUSTAT, no período de 1950 a 1971. Os primeiros 13 anos do período (1954 a 1966) foram utilizados para prever os parâmetros para os próximos 4 anos (1967 a 1971) e testar a habilidade preditiva do modelo. Ao final, todo o período de 17 anos foi testado em uma regressão. Utilizaram o modelo para prever dois parâmetros da distribuição de retornos anuais de cada ativo: o seu beta e a variância do seu retorno próprio (não sistemático). Na regressão feita utilizando-se o beta como variável dependente, foram encontrados coeficientes significantes, mas o padrão de sinais não foi o esperado. Dos 13 coeficientes analisados, apenas 4 apresentaram o coeficiente esperado, 3 o sinal contrário e 6 corresponderam a efeitos não significativos. Na regressão, utilizando-se a variância como variável dependente, encontraram 7 dos 8 coeficientes com o sinal esperado, e o último não apresentou significância estatística. 
Outro trabalho, apresentado nesse mesmo ano, foi o de Breen e Lerner (1973). Os autores pesquisaram empiricamente a associação entre variáveis contábeis e o beta de mercado de 1400 empresas norte-americanas no período 1965-1970, com cotações disponíveis na COMPUSTAT. As variáveis analisadas foram: endividamento (forma simples e quadrática), crescimento, estabilidade do crescimento dos lucros, tamanho da empresa, dividend payout e número de ações negociadas. Ressaltaram que o beta em si nunca é observado, sendo possível inferir apenas sobre a estimativa do beta. Dividiram, portanto, a pesquisa em duas etapas: i) estabeleceram uma relação entre o beta e sua estimativa e ii) buscaram uma associação entre a estimativa do beta e as variáveis analisadas. A maior parte dos coeficientes encontrados não foi estatisticamente diferente de zero e o $\mathrm{R}^{2}$ encontrado foi relativamente baixo (variou de $6 \%$ a 54\%). Entretanto, os sinais dos coeficientes obtidos foram conforme o esperado. Como conclusão, os autores destacam a importância das decisões financeiras (investimento, financiamento e distribuição de lucros) como fundamentais na volatilidade das ações.

Lev (1974) baseou suas pesquisas com o foco na decisão gerencial em 122 empresas dos setores elétrico, siderúrgico e petrolífero de 1949 a 1968. O autor utilizou a alavancagem operacional e a sua relação com o risco das ações das companhias. O objetivo foi verificar se a relação poderia ser utilizada para estimar o beta. Seus resultados evidenciaram pouco poder explicativo, observando que existem outras variáveis que explicam a variação do risco além da alavancagem operacional.

Lev e Kunitzky (1974) procuraram verificar qual das variáveis contábeis possuíam maior associação com os riscos sistemático e total, separadamente. Partiram do pressuposto de que empresas com maior estabilidade nos seus fluxos de vendas, dividendos, investimentos de capital e lucros possuem uma maior eficiência operacional, por reduzir-se a incerteza quanto ao risco da empresa. A amostra foi composta por 260 empresas com informações disponíveis na COMPUSTAT durante o período de 1949 a 1968. Os resultados do teste aplicado demonstraram que há uma associação estatisticamente significante entre a estabilidade das séries de informações operacionais da empresa e o seu risco, seja o risco total $\left(\mathrm{R}^{2}\right.$ de $\left.47 \%\right)$ ou o sistemático $\left(\mathrm{R}^{2}\right.$ de $\left.65 \%\right)$.

Beaver e Manegold (1975) examinaram o grau de associação entre o beta de mercado e contábil, analisando três diferentes cálculos para o beta contábil. Os três cálculos foram: beta baseado nas receitas líquidas por dólar de ativos; beta baseado no retorno das ações ordinárias 
e beta baseado no índice P/L. A amostra foi de 254 empresas, semelhantes às do estudo de Beaver et al. (1970), sendo menor apenas devido à ocorrência de fusões e falta de informações disponíveis. A segunda amostra envolveu 94 das 99 empresas analisadas por Gonedes (1973), sendo também menor por haver requisitos quanto ao mínimo de 15 empresas do mesmo setor. O período analisado foi de 1951 a 1969, subdividido em 1951 a 1960 e 1961 a 1969. Encontrou que $20 \%$ da variação no beta de mercado é explicada pelos betas contábeis. O lucro contábil dividido pelo valor de mercado de cada ação foi o que apresentou maior poder de explicação. O desvio-padrão encontrado para os betas contábeis foi bem maior que os betas de mercado, indicando um maior erro na mensuração dos betas contábeis. As correlações obtidas indicaram associação entre os betas de mercado e contábeis para diferentes medidas de beta e diferentes períodos, ao contrário de Gonedes, que encontrou associação significante em apenas um dos casos.

Bildersee (1975) estudou a associação entre os betas de mercado e medidas de risco contábeis por meio de 97 ações ordinárias e preferenciais não conversíveis listadas na NYSE no período de março de 1956 a março de 1966, com restrições quanto ao volume negociado para garantir a liquidez dos papéis analisados. As variáveis analisadas foram: rentabilidade, endividamento (dívida/PL e referenciais/ordinárias), liquidez corrente, eficiência (vendas/ações ordinárias) e cobertura de juros (fluxo de caixa/capital de terceiros). Além dessas, outras três, também, foram incluídas na análise: taxa de crescimento (média geométrica da variação dos ativos), desvio-padrão do índice L/P e o beta contábil. Para cada ação foram estimados os betas com 120 pontos mensais e levantados os dados contábeis necessários. Agruparam os ativos em carteiras para minimizar os riscos próprios dos ativos, uma vez que os betas de mercados medem apenas o risco sistemático e as medidas contábeis contemplam o risco total. $\mathrm{Na}$ análise de associação, constatou que a inclusão das variáveis crescimento, variabilidade dos lucros e betas contábeis melhorou a qualidade das regressões substancialmente, explicando de 14,9\% a 57,9\% da variância não explicada anteriormente. A análise dos ativos agrupados em carteiras demonstrou maior poder explicativo que no caso dos ativos individuais, corroborando a hipótese de que analisar o risco de carteiras, que possuem o risco não sistemático minimizado, aumenta o nível de associação com os betas de mercado.

Em um estudo publicado em 1976, Thompson investigou se a magnitude do beta de mercado pode ser explicada por informações contábeis. A amostra foi preenchida por 290 empresas com dados de 1949 a 1968 e foram realizadas análises de correlação de firmas individuais e 
carteiras e regressões. Foram realizados testes da relação entre o beta de mercado e 43 variáveis contábeis sobre dividendos, lucros, receitas, endividamento, liquidez, crescimento e tamanho. O modelo revelou três principais variáveis inerentes ao risco calculado pelo beta contábil, são elas: variações nos lucros, dividendos e o múltiplo de lucro com flutuações macroeconômicas em sua fórmula. Muitas variáveis apresentaram poder de correlação com os betas de mercado e modelos de regressão, utilizando algumas variáveis, demonstraram-se adequados para explicar o desempenho dos betas. Somado a isso modelos que utilizaram a covariância (de betas contábeis) em sua fórmula apresentam superiores empiricamente para explicar diferenças no risco sistemático do que médias ou variâncias dessas variáveis.

Bowman (1979) fez um estudo teórico abordando a relação entre as variáveis contábeis e a mensuração do risco de mercado. O autor apresenta uma associação teórica entre as variáveis contábeis, alavancagem, risco de falência, juros, beta contábil, variação dos lucros, dividendos, tamanho e crescimento, e sua relação com o risco sistemático do mercado. Conclui que há uma relação teórica entre o risco sistemático, a alavancagem da firma e o beta contábil. Quanto às demais variáveis, não foi verificada relação com o risco de mercado.

Hill e Stone (1980) estudaram se os betas contábeis poderiam ser usados para projetar os betas de mercado, investigaram a relação entre as medidas de risco sistemático baseadas no mercado e em dados contábeis, além de analisar o efeito da estrutura financeira no risco sistemático. A amostra englobou o período de 1947 a 1974 (150 empresas), subdividido em dois subperíodos: de 1947 a 1960 (240 empresas) e 1961 a 1974 (324 empresas). Concluíram que os números contábeis possuem, dentro de uma estrutura de risco, poder para explicar os betas de mercado futuros. Além disso, demonstraram que fazem isso dentro de uma estrutura de risco estatisticamente significativa. Atestaram que mudanças na estrutura de endividamento e no risco operacional são determinantes importantes nas alterações dos betas de mercado de um período para o seguinte. Dessa forma, a previsão dos betas de mercado pode ser aprimorada se for possível prever a estrutura financeira e o risco operacional da empresa.

Elgers (1980) discorreu sobre se os números contábeis apresentariam a melhor fórmula de se obter uma medida de risco. Em sua percepção, os números contábeis podem ser úteis permitindo um ajuste do beta de mercado, que, muitas vezes, pode ser enviesado, levando à identificação de um beta correto para a empresa. Encontrou muito poucas relações entre o 
beta de mercado e os números contábeis, entretanto defendeu a utilização das medidas de forma conjunta ou complementar.

Mandelker e Rhee (1984) estudaram a associação entre o beta de mercado e as alavancagens operacional e financeira de 255 empresas norte-americanas no período 1957-1976, agrupadas em portfólios de 5 empresas. Adicionalmente, verificaram se havia um trade-off entre as duas alavancagens e propuseram um modelo de beta contábil. As variáveis foram: a relação entre ativos imobilizados e ativos totais (operacional) e o índice de dívidas totais sobre ativos totais (financeira). Propuseram um modelo teórico para a relação entre os betas de mercado e as alavancagens. Em relação ao modelo proposto por Hamada (1971), esse possui a vantagem de medir a alavancagem por meio de números de fluxo e não de estoque. As associações foram testadas utilizando o coeficiente de correlação de Pearson. Encontraram associações positivas e estatisticamente significantes entre as duas alavancagens das empresas e os betas de mercado das ações e um trade-off entre os dois graus de alavancagem.

Ismail e Kim (1989) analisaram lucro líquido, EBIT, EBITDA e lucro operacional, em uma amostra de 272 empresas entre os anos de 1966 a 1985. Eles encontraram uma relação significante entre as quatro medidas e o risco sistemático calculado pelo beta de mercado, sendo uma associação mais forte para a carteira total (dados em painel) do que para a relação individual de cada empresa (regressão), confirmando o que fora constatado por Bildersee (1975) em seu estudo.

Karels e Sackley (1993) estudaram a associação entre betas contábeis e de mercado entre 71 instituições financeiras nos Estados Unidos. Como medida de betas contábeis, usaram a $1^{\text {a }}$ diferença do retorno sobre o ativo total e a $1^{\mathrm{a}}$ diferença do retorno sobre vários índices de mercado. Encontraram associação entre 30\% a 60\% dependendo do índice de mercado adotado.

Em outras pesquisas, Ball et al. (1993) constataram que o lucro contábil pode ser uma proxy do risco de mercado por serem positivamente associadas com mudanças no risco. Os autores observaram uma relação de influência entre o risco de mercado e os dados contábeis, sendo que, em seu trabalho, os primeiros influenciam os segundos. Dechow (1994), ao desenvolver um trabalho sobre medidas de desempenho em empresas, mostrou que o poder explicativo do lucro contábil sobre intervalos de medidas é fortemente associado com o retorno da ação. 
Laveren et al. (1997) compararam a habilidade das variáveis contábeis de estimar os betas de mercado alavancados e não alavancados.

Almisher e Kish (2000) utilizaram a relação entre variáveis de mercado e variáveis contábeis na Abertura de Capital de Empresas. Seus resultados confirmaram que os betas contábeis são associados.

St-Pierre e Bahri (2006) buscaram entender se o beta contábil poderia ser usado como proxy de risco para empresas de capital fechado no Canadá. O artigo apresentou um estudo empírico usando análise fatorial e regressão para medir se os componentes do risco eram relacionados com o beta contábil. O resultado mostrou que o beta contábil (do ROE) não constitui uma medida global de risco explicando talvez somente o risco financeiro e não os riscos operacionais, tecnológicos e legais.

Brimble e Hodgson (2007) examinaram a relação contemporânea entre a informação contábil e várias medidas de betas de mercado. Foram utilizados cinco tipos de betas de mercado e nove variáveis contábeis classificadas em operacionais, financeiras e de crescimento. $\mathrm{O}$ resultado mostra uma associação forte entre variáveis operacionais e de crescimento e os betas contábeis que se mostra constante ao longo do tempo.

Mais recentemente, Ecker et al. (2009) compararam risco previsto pelo mercado (betas previstos pelos analistas) e informações contábeis. O estudo encontrou que as duas medidas tinham um poder similar de explicação dos reais retornos das ações, porém as variáveis contábeis apresentaram um poder maior de explicação para o custo de capital próprio das empresas em ambientes com baixa quantidade de informações.

Nekrasov e Shroff (2009) propuseram uma metodologia para incorporar medidas de risco oriundas de variáveis contábeis dentro de modelos de avaliação. Foi calculado um modelo envolvendo betas contábeis calculado por meio do ROE, betas de tamanhos e betas de múltiplos de lucro por ação. O resultado mostrou que o modelo proposto capturou tendências de redução e crescimento nos preços das ações.

Dessa forma, as pesquisas sobre a associação entre variáveis contábeis e risco sistemático variam seus resultados pelo grau de relacionamento entre eles, porém a grande maioria aponta 
para a existência de certa associação. Essas diferenças podem ser atribuídas às diferentes formas de cálculo de variáveis contábeis utilizadas ou às diferenças nos índices de retorno do mercado ou, ainda, nas diferenças de período de tempo analisado. Entretanto, não houve estudos conclusivos sobre a variáveis contábeis e o risco sistemático. Somado a isso, o número de estudos sobre essa relação ainda é considerado restrito, mesmo na literatura internacional, é o que afirmam Lopes e Martins (2005). A seguir, serão apresentadas pesquisas sobre a informação contábil e o risco sistemático no mercado brasileiro.

\subsubsection{Informação contábil e o risco sistemático no Brasil}

Essa revisão levantou as pesquisas que verificavam a associação entre variáveis contábeis com medidas de risco de mercado. Apesar de existirem alguns trabalhos recentes, segundo Lopes e Martins (2005), tais estudos permanecem praticamente inexplorados no Brasil.

O primeiro trabalho no Brasil, segundo Oda (2004), foi o de Ribeiro Neto e Famá (2001), que, com um caráter mais expositivo, afirmaram existir correlação entre o beta contábil e de mercado entre os anos de 1995-1999, porém de forma não conclusiva. Compararam o beta de mercado e o beta contábil de 19 empresas de capital aberto negociadas na BM\&FBOVESPA, dos setores de papel e celulose, siderurgia e carnes e derivados. Os betas contábeis foram estimados a partir da regressão entre a variação percentual do lucro anual da empresa contra a variação percentual do lucro do setor (obtido a partir da soma dos lucros de cada empresa a ele pertencente), subtraindo-se de ambas as variações a rentabilidade do CDI, admitido livre de risco. Segundo os autores, "O estudo original feito por Beaver e Manegold (1975) analisou uma amostra de empresas norte-americanas, em uma economia estável”, e o objetivo foi o de verificar a aplicabilidade do teste no mercado acionário brasileiro. Os resultados mostraramse diferentes dos obtidos no estudo original, não apresentando relação entre as variáveis.

Na sequência, Cupertino e Ogliari (2002) discutiram a correlação entre o retorno sobre o ativo e o beta das empresas brasileiras. Encontraram que a rentabilidade observada em uma determinada entidade não tem simetria com a avaliação do seu risco. Como parâmetro de rentabilidade foi utilizado o retorno sobre o ativo (ROA) e como medida de risco o beta de mercado calculado pelo CAPM $(\beta)$. 
Lacey et al. (2004) teve como objetivo descrever e aplicar uma metodologia para calcular o custo de capital próprio de empresas de capital fechado utilizando o beta de mercado e suas variáveis contábeis. Realizou um estudo teórico extraindo uma relação entre variáveis contábeis e betas de mercado de empresas de capital aberto. Feito isso, usou o modelo para calcular o beta de uma empresa fechada do setor de bebidas e alimentos que tenha disponível seus balanços.

Mendonça Neto e Bruni (2004) observaram o retorno sobre o patrimônio líquido (ROE) de cada empresa, regredido contra o retorno sobre o patrimônio líquido do mercado brasileiro, a fim de se encontrar o beta contábil, além de utilizar o coeficiente de variação do lucro líquido e a variabilidade do retorno sobre o patrimônio líquido como medida de risco da empresa. Os resultados encontrados mostram que a associação, o mercado e as variáveis contábeis não são significativos e não permitem dizer que as variáveis estudadas explicam o retorno das ações.

Em um estudo premiado, Oda (2004) verificou a possibilidade de estimação dos betas de mercado a partir de dados contábeis, mediante a aplicação de modelos teóricos e testes empíricos que relacionam conceitos de finanças corporativas com elementos da teoria de portfólios. Em uma amostra com 93 empresas que apresentaram ações negociadas na BM\&FBOVESPA, durante o período de 1995 a 2003, examinou a possibilidade de melhorar o processo de previsão de betas de mercado utilizando-se betas históricos associados a indicadores contábeis. Para verificar a relação entre indicadores contábeis e betas de mercado, foram selecionados quatro grupos de variáveis: betas contábeis, graus de alavancagem, indicadores de estrutura de capital e indicadores contábeis operacionais. Os betas contábeis foram calculados por intermédio de indicadores de lucro como: LAJIR, Lucro líquido e lucro líquido ajustado pelo pagamento de juros sobre o capital, além disso, essas variáveis foram calculadas em sua forma nominal, na primeira diferença e em percentual de crescimento. Os resultados indicam que o grau de alavancagem financeira e a estrutura de capital apresentam correlações positivas e estatisticamente significantes com os betas de mercado, enquanto o crescimento do ativo e a taxa de pagamento de dividendos mostraram associações negativas, também de elevada significância. Foram encontradas fortes evidências de que os indicadores contábeis podem ser utilizados para melhorar a previsão de betas de mercado, principalmente quando associados a betas históricos. 
Fernandez (2005) buscou averiguar se a estimativa de risco calculado, por meio de dados contábeis, possui relação com o risco sistemático de mercado. Como medida de risco utilizase o parâmetro, beta, que mede o risco sistemático, advindo do modelo de precificação de ativos o CAPM. O objetivo foi proporcionar a utilização de um beta contábil, medido mediante dados contábeis, em ambientes em que o mercado não seja capaz de estimar o risco. Tal situação pode ocorrer em ambientes cujo mercado não represente bem sua economia ou em empresas que não possuam ações negociadas em Bolsa. A amostra compreendeu as ações das 50 empresas de capital aberto mais líquidas negociadas na BM\&FBOVESPA (BOVESPA). Os dados foram selecionados trimestralmente entre os anos de 1996 e 2004. Utilizaram-se dois métodos diferentes para o cálculo do beta contábil: i) o modelo do beta pelo CAPM e ii) o proposto pela teoria de Hamada. O beta de mercado foi obtido por intermédio do sistema Economática, para o período e empresas componentes da amostra. Em seguida, realizaram-se testes estatísticos de aderência: correlação e inferência estatística, a fim de verificar o grau de associação entre os betas contábeis calculados e o de mercado. As evidências estatísticas indicam baixos índices de correlação, mas o teste de inferência comprovou haver uma relação estatisticamente significante entre o beta contábil e o risco sistemático.

Munhoz (2006) teve como objetivo verificar se é possível utilizar o lucro líquido e sua variação como proxy de beta de mercado. Para isso, utilizou 80 empresas entre os anos de 1996 e 2005. O resultado apresentou os sinais corretos, porém as correlações foram pouco significativas e fracas, demonstrando que a medida contábil não é apropriada para substituir o beta nas suas diversas situações.

Cardoso e Amaral (2000) realizaram uma comparação entre os resultados da análise dinâmica do capital de giro e do grau de risco (modelo Fleureit) em relação ao mercado, por meio do beta do modelo CAPM - Capital Asset Pricing Model. Com o uso da variável CDG do modelo dinâmico, a correlação encontrada entre essas duas medidas aponta uma tendência que associa o grau de risco da empresa em relação ao mercado com o seu capital de giro.

Gusmão e Cherobim (2009) analisaram as empresas de capital aberto com ações negociadas na BM\&FBOVESPA (BOVESPA), emissoras de ADR, negociados na Bolsa de Valores de Nova Iorque (NYSE), North American Securities Dealers Automated Quotation System (NASDAQ) e na OTC Bulletin Board. O objetivo foi verificar se os betas contábeis podem 
ser um substituto do beta de mercado para a avaliação dos títulos dessas empresas. Os resultados encontrados mostram que a correlação não é significativa e não permitem dizer que o beta contábil seja válido como substituto do beta de mercado e como medida de risco sistemático confirmando os estudos teóricos e, ainda, que o uso de informações contábeis para análise é uma alternativa para empresas brasileiras, principalmente para as empresas de capital fechado, que não possuem informações de mercado disponíveis para estimar o seu risco sistemático. Verifica-se que os betas contábeis dependem de outras condições macroeconômicas, para que possam funcionar como indicadores significativos das diferenças setoriais.

Costa (2007) apresenta o beta contabilístico como possível proxy para a taxa de retorno exigida em análise de projetos de investimentos, sintetizada por Richard A. Brealey e Stewart C. Myers para fins pedagógicos.

Em outro estudo, Minardi et al. (2007) levantaram quais eram as características de empresas com maiores ou menores betas de mercado. Os resultados demonstraram que quanto mais se exporta, menor é o Beta CAPM. Em outra ponta, quanto maior a alavancagem financeira, o tamanho do ativo e variabilidade da liquidez corrente, maior será o Beta CAPM. Esses estudos, apesar de não fazerem uma associação direta entre a variação de resultados e o risco sistemático, demonstraram que esse último está relacionado com características da empresa expressas em suas informações contábeis.

Rodrigues et al. (2008) verificou a hipótese da utilização do Beta Contábil em substituição ao Beta CAPM para empresas de capital fechado. Para tanto, foi utilizado um estudo empírico, por intermédio de prova não paramétrica Mann-Whitney U, em ações de empresas do setor siderúrgico e metalúrgico no período de 2001 a 2005. Concluiu-se, por fim, dos resultados obtidos, que o Beta Contábil substitui, significativamente, o Beta CAPM, para a amostra selecionada.

Teixeira e Valle (2008), também, observaram a existência entre betas calculados a partir de dados de mercado (cotações e dividendos) e betas baseados em dados contábeis. As análises foram realizadas para uma amostra de 101 empresas negociadas na BM\&FBOVESPA, incluindo representantes de 17 setores da economia. Os cálculos dos betas a partir de dados contábeis foram obtidos das variáveis, lucro operacional, lucro líquido, lucro por ação, fluxo 
de caixa e lucro antes dos impostos em relação a betas de mercado alavancados e não alavancados. Contrariamente a outros estudos, os resultados indicaram que há correlação significativa entre os betas, dependendo da especificação das variáveis contábeis. O beta contábil obtido do lucro líquido foi o que apresentou a associação mais expressiva com o beta de mercado, chegando a coeficientes de $42 \%$. Esse estudo apresentou vários resultados positivos (sinais positivos esperados e nível de significância adequado) que podem ser vistos como um indício de que a associação entre variação dos resultados contábeis e medidas de risco de mercado são concretas para o caso brasileiro.

Santos e Silva (2009) investigaram a relação existente entre um conjunto de cinco variáveis contábeis (liquidez, endividamento total, variação do lucro, alavancagem e crescimento do ativo) e o risco do ativo com base na APT. O estudo foi realizado em apenas três bancos (Banco do Brasil, Bradesco e Banco do Nordeste do Brasil) no período de 1999 a 2008 . Foi constatado que, em relação às variáveis estudadas, não foi possível estabelecer a mesma correlação, em sua totalidade, com o que a teoria prediz.

Mais recentemente, Ilha et al. (2009) testaram a associação entre o beta de mercado e o parâmetro contábil teoricamente construído, denominado beta contábil, e a existência de relações mais ou menos robustas para determinados grupos de companhias. A amostra foi composta por 83 empresas negociadas na BOVESPA entre os períodos de 1996 e 2007. Os resultados indicaram existir relação estatística significante entre todos os betas contábeis testados (construídos a partir dos indicadores: tamanho, crescimento, liquidez, grau de alavancagem operacional, grau de alavancagem financeira, grau de alavancagem total, proporção de pagamento de dividendos e estrutura de capital) quando os dados são testados sob a estrutura em painel.

Dessa forma, somente alguns dos estudos levantados apontaram uma relação positiva entre a variação dos resultados e o risco sistemático das empresas no Brasil. Entretanto, essas associações, em comparação a estudos feitos em outros mercados, apresentaram menores níveis de coeficientes de correlação. Enquanto os estudos de Ball e Brown (1968), Beaver et al. (1970), Beaver e Manegold (1975) apresentaram coeficientes que chegaram à ordem de $66 \%$, os estudos, no Brasil, apresentaram coeficientes que variaram de $19 \%$ a $42 \%$ com um número não muito expressivo de correlações positivas e estatisticamente significativas. 



\section{METODOLOGIA}

O estudo pretendeu identificar se os betas contábeis de uma empresa possuem relação com seu risco sistemático, com ações negociadas na BM\&FBOVESPA, demonstrando, assim, que os relatórios contábeis cumprem seu papel e constituem um arcabouço de informações importantes para o usuário investidor. Nesse capítulo, é apresentada a metodologia adotada para se atingir o objetivo da pesquisa. Richardson (1999, p. 22) define método como "o caminho ou a maneira para chegar a determinado fim ou objetivo." Desse modo, será explicitado: o tipo de pesquisa a ser realizada; o problema; as hipóteses e variáveis principais, além da explanação sobre os conceitos e etapas dos métodos a serem utilizados; a Análise de Dados em Painel, a Análise de Componentes Principais e a Correlação Canônica.

Uma pesquisa científica pode ser classificada sob vários enfoques. Silva e Menezes (2000) esclarecem que há diversas classificações para a pesquisa, mas o importante é obedecer aos requisitos inerentes a cada tipo. De acordo com Cervo e Bervian (2002), o método científico é apenas um conjunto ordenado de procedimentos que se mostraram eficientes ao longo da história na busca do saber. Observando o objetivo do trabalho exposto no parágrafo anterior, esta pesquisa se caracteriza por ser:

- Método hipotético dedutivo: o trabalho é hipotético dedutivo, de acordo com Marconi e Lakatos (2003), pois se inicia pela percepção de uma lacuna nos conhecimentos, acerca da qual formula hipóteses e, pelo processo de inferência dedutiva, testa a predição da ocorrência de fenômenos abrangidos pela hipótese ou tese central.

- Pesquisa aplicada: segundo Cervo e Bervian (2002), o pesquisador tem como meta o saber, buscando satisfazer uma necessidade para fins práticos mais ou menos imediatos, buscando soluções para problemas concretos.

- Pesquisa descritiva: caracteriza-se por observar, registrar, analisar e correlacionar fatos ou fenômenos sem manipulá-los. Procura descobrir, com precisão, a frequência com que um fenômeno ocorre, sua relação e conexão com outros, sua natureza e característica. (MARTINS, 1994).

- Pesquisa quantitativa: segundo Richardson (1999), o método de investigação quantitativo caracteriza-se pelo emprego da quantificação, tanto nas modalidades de 
coleta de informações, quanto no seu tratamento por meio de técnicas estatísticas. O trabalho utiliza dados disponíveis em agentes de mercado e nas demonstrações financeiras das empresas pesquisadas e emprega a técnicas estatísticas de análise. Ainda, Richardson (1999) afirma que o método quantitativo é, frequentemente, utilizado nos estudos descritivos, naqueles que procuram descobrir e classificar a relação entre variáveis, bem como nos que investigam a causalidade entre fenômenos. O presente estudo, por sua vez, consiste em um método quantitativo de pesquisa.

- Estudo empírico analítico: segundo Martins (1994), como última característica, podese enquadrar o trabalho como um estudo empírico analítico. Essa abordagem apresenta, em comum, a utilização de técnicas de coleta, tratamento e análise de dados marcadamente quantitativas. Tem forte preocupação com a relação causal entre as variáveis e a validação da prova científica é buscada por intermédio de testes dos instrumentos, graus de significância e sistematização das definições operacionais.

Portanto, a pesquisa desenvolvida consiste em um estudo empírico analítico, com método de abordagem hipotético dedutivo: é do tipo descritiva e quantitativa.

\subsection{Hipóteses}

De acordo com Triviños (1987), a hipótese envolve uma possível verdade e/ou um resultado provável. Kerlinger, (1980 p. 38) explana que as hipóteses

\footnotetext{
são enunciados de relações e, como os problemas, devem implicar a testagem das relações enunciadas. Ambos enunciam relações, só que os problemas são sentenças interrogativas e as hipóteses sentenças afirmativas. Embora quase idênticos em substância, a diferença importante é que as hipóteses geralmente são mais específicas do que os problemas e estão mais próximas das operaçõos de teste e pesquisa.
}

A hipótese é "uma suposta, provável e provisória resposta a um problema que provocou a pesquisa, cuja validez ou sustentação será verificada através da pesquisa." (MARCONI; LAKATOS, 2003, p. 68). Em resumo, as hipóteses correspondem a verdades intuídas com o apoio de uma teoria e os resultados as verificarão, rejeitando ou não as afirmações propostas.

O objetivo desta pesquisa foi identificar se os betas contábeis de uma empresa possuem relação com seu risco sistemático, calculado por meio do beta de mercado, para as ações 
negociadas na BM\&FBOVESPA. Para atender a esse objetivo, foram testadas as seguintes hipóteses, apresentadas na forma nula e que serão testadas ao nível de confiança de $\alpha=95 \%$ :

$\mathbf{H}_{\mathbf{0 , 1}}$ : Existe associação entre o beta contábil de uma empresa e o beta de mercado de suas ações.

$\mathbf{H}_{\mathbf{0}, 2}$ : O beta contábil de uma empresa pode explicar o beta de mercado de suas ações.

$\mathbf{H}_{\mathbf{0}, 3}$ : O beta contábil de uma empresa pode antecipar o beta de mercado de suas ações.

$\mathbf{H}_{\mathbf{0}, \mathbf{4}}$ : O beta contábil de uma empresa pode melhorar a previsão do beta de mercado de suas ações.

$\mathbf{H}_{\mathbf{0 , 5}}$ : Os betas contábeis e betas de mercado possuem componentes comuns;

$\mathbf{H}_{0,6}$ : Os componentes comuns podem ser correlacionados canonicamente.

$\mathrm{Na}$ sequência, é descrita a composição da amostra de empresas negociadas na BM\&FBOVESPA e a coleta de dados.

\subsection{Amostra e Coleta de Dados}

Martins (1994) afirma que os métodos de amostragem se dividem em dois: probabilístico e não probabilístico. Estudos probabilísticos consistem em coletar dados aleatoriamente, sem nenhuma interferência do pesquisador. Estudos não probabilísticos correspondem àqueles em que não há aleatoriedade no processo de coleta de dados. Martins (1994) lembra que existem, ainda, dois métodos não probabilísticos de amostragem que se destacam: a amostragem por conveniência e a amostragem por julgamento. De acordo com Anderson et al. (2003), a amostragem por julgamento corresponde a um método de não probabilidade de amostragem em que os elementos são selecionados para a amostra com base no julgamento do pesquisador. Como será explicado nos próximos parágrafos este estudo utilizou o método não probabilístico por julgamento para a escolha de empresas uma vez que selecionou entre as empresas negociadas na BM\&FBOVESPA aquelas que preenchiam determinados quesitos.

Primeiramente, a amostra contou com 687 ações e nessas havia mais de uma ação da mesma empresa. O segundo passo foi, então, selecionar para cada empresa apenas a ação que possuía maior volume negociado em Bolsa no ano de 2009. Feito isso, o número de empresas da amostra reduziu-se para 384 empresas. O passo seguinte foi, então, excluir as empresas do setor financeiro. A não utilização de empresas do setor financeiro se deu pelo fato de elas 
apresentarem uma natureza de atividade bastante diferenciada das demais, o que as leva a possuírem diferentes direcionadores de valor. É o que evidencia Ehrbar (1999, p.94) ao afirmar que "na verdade, as medições convencionais de lucratividade são disfuncionais para bancos ou qualquer empresa do setor financeiro." Por fim, foram excluídas as empresas que não possuíam informações de demonstrações contábeis e de cotações de mercado desde 1995. Dessa forma, a amostra totalizou 97 empresas de 15 setores econômicos conforme Quadro 2:

Como a pesquisa objetivou identificar se os betas contábeis de uma empresa possuem relação com seu risco sistemático, calculado por meio do beta de mercado, foram selecionados os dados entre o período de 1995 a 2009.

Malhotra (2001) lembra que os dados podem ser primários ou secundários. Os classificados como secundários são aqueles que já foram coletados para objetivos que não os do problema em pauta. Por essa razão, os dados deste estudo são considerados secundários. Como vantagem, os dados secundários são de fácil acesso, obtenção rápida e localizados de forma barata. (Ibid., 2001).

Quanto aos dados utilizados nesta pesquisa, eles se caracterizaram por serem variáveis econômico-financeiras extraídas das informações não consolidadas, trimestrais e em moeda corrente. Foram todos extraídos do sistema Economática (2009), em que são disponibilizadas demonstrações financeiras, cotações, indicadores financeiros, indicadores técnicos, indicadores de mercado, entre outros dados econômico-financeiros de todas as empresas listadas na Bovespa. Este estudo utilizou as demonstrações contábeis para extrair dados de rentabilidade, endividamento e informações operacionais. Nos indicadores técnicos, foram extraídas informações de mercado como cotações e valor da empresa. 
Quadro 2 - Amostra

\begin{tabular}{|c|c|c|c|c|c|}
\hline Empresa & Ação & Setor & Empresa & Ação & Setor \\
\hline Ambev & $\mathrm{PN}$ & Alimentos e Beb & Fosfertil & $\mathrm{PN}$ & Química \\
\hline BRF Foods & ON & Alimentos e Beb & M GPoliest & $\mathrm{ON}$ & Química \\
\hline Cacique & $\mathrm{PN}$ & Alimentos e Beb & Millennium & PNA & Química \\
\hline Iguacu Cafe & PNB & Alimentos e Beb & Unipar & PNB & Química \\
\hline Minupar & $\mathrm{ON}$ & Alimentos e Beb & Yara Brasil & $\mathrm{PN}$ & Química \\
\hline Grazziotin & $\mathrm{PN}$ & Comércio & Acos Vill & $\mathrm{ON}$ & Siderur \& Metalur \\
\hline Lojas Americ & $\mathrm{PN}$ & Comércio & Confab & $\mathrm{PN}$ & Siderur \& Metalur \\
\hline Lojas Renner & ON & Comércio & Eluma & $\mathrm{PN}$ & Siderur \& Metalur \\
\hline P.Acucar-Cbd & PNA & Comércio & Ferbasa & $\mathrm{PN}$ & Siderur \& Metalur \\
\hline Azevedo & $\mathrm{PN}$ & Construção & Forjas Taurus & $\mathrm{PN}$ & Siderur \& Metalur \\
\hline Lix da Cunha & $\mathrm{PN}$ & Construção & Gerdau & $\mathrm{PN}$ & Siderur \& Metalur \\
\hline Sultepa & $\mathrm{PN}$ & Construção & Gerdau Met & $\mathrm{PN}$ & Siderur \& Metalur \\
\hline Brasmotor & $\mathrm{PN}$ & Eletroeletrônicos & Hercules & PN & Siderur \& Metalur \\
\hline IGB S/A & $\mathrm{ON}$ & Eletroeletrônicos & Kepler Weber & $\mathrm{ON}$ & Siderur \& Metalur \\
\hline Itautec & $\mathrm{ON}$ & Eletroeletrônicos & Metisa & $\mathrm{PN}$ & Siderur \& Metalur \\
\hline Whirlpool & $\mathrm{PN}$ & Eletroeletrônicos & Mundial & $\mathrm{PN}$ & Siderur \& Metalur \\
\hline Ampla Energ & $\mathrm{ON}$ & Energia Elétrica & Paranapanema & $\mathrm{ON}$ & Siderur \& Metalur \\
\hline Ceb & PNB & Energia Elétrica & Sid Nacional & $\mathrm{ON}$ & Siderur \& Metalur \\
\hline Celesc & PNB & Energia Elétrica & Usiminas & PNA & Siderur \& Metalur \\
\hline Cemig & $\mathrm{PN}$ & Energia Elétrica & Brasil Telec & $\mathrm{PN}$ & Telecomunicações \\
\hline Cesp & PNB & Energia Elétrica & Telemar N L & PNA & Telecomunicações \\
\hline Coelce & PNA & Energia Elétrica & Telesp & $\mathrm{PN}$ & Telecomunicações \\
\hline Copel & PNB & Energia Elétrica & Alpargatas & PN & Textil \\
\hline Eletrobras & $\mathrm{ON}$ & Energia Elétrica & Botucatu Tex & $\mathrm{PN}$ & Textil \\
\hline Light S/A & $\mathrm{ON}$ & Energia Elétrica & Buettner & $\mathrm{PN}$ & Textil \\
\hline Bardella & $\mathrm{PN}$ & Máquinas Indust & Cambuci & $\mathrm{PN}$ & Textil \\
\hline Inds Romi & $\mathrm{ON}$ & Máquinas Indust & Cia Hering & $\mathrm{ON}$ & Textil \\
\hline Weg & $\mathrm{ON}$ & Máquinas Indust & Coteminas & $\mathrm{PN}$ & Textil \\
\hline Vale & PNA & Mineração & Dohler & PN & Textil \\
\hline Alfa Consorc & $\mathrm{PNF}$ & Outros & Fab C Renaux & $\mathrm{PN}$ & Textil \\
\hline Alfa Holding & $\mathrm{PNB}$ & Outros & Karsten & $\mathrm{PN}$ & Textil \\
\hline Bahema & $\mathrm{ON}$ & Outros & Marisol & $\mathrm{PN}$ & Textil \\
\hline Dixie Toga & $\mathrm{PN}$ & Outros & Pettenati & $\mathrm{PN}$ & Textil \\
\hline Docas & $\mathrm{ON}$ & Outros & Schlosser & $\mathrm{PN}$ & Textil \\
\hline Inepar & $\mathrm{PN}$ & Outros & Tex Renaux & PN & Textil \\
\hline Itausa & $\mathrm{PN}$ & Outros & DHB & $\mathrm{PN}$ & Veiculos e peças \\
\hline Mont Aranha & $\mathrm{ON}$ & Outros & Embraer & $\mathrm{ON}$ & Veiculos e peças \\
\hline Petropar & $\mathrm{PN}$ & Outros & Fras-Le & $\mathrm{PN}$ & Veiculos e peças \\
\hline Sansuy & PNA & Outros & Iochp-Maxion & $\mathrm{ON}$ & Veiculos e peças \\
\hline Saraiva Livr & $\mathrm{PN}$ & Outros & Marcopolo & $\mathrm{PN}$ & Veiculos e peças \\
\hline Souza Cruz & $\mathrm{ON}$ & Outros & Metal Leve & $\mathrm{PN}$ & Veiculos e peças \\
\hline Tectoy & $\mathrm{PN}$ & Outros & Plascar Part & $\mathrm{ON}$ & Veiculos e peças \\
\hline Trevisa & $\mathrm{PN}$ & Outros & Pro Metalurg & PNB & Veiculos e peças \\
\hline Klabin S/A & $\mathrm{PN}$ & Papel e Celulose & Randon Part & $\mathrm{PN}$ & Veiculos e peças \\
\hline Suzano Papel & PNA & Papel e Celulose & Recrusul & $\mathrm{PN}$ & Veiculos e peças \\
\hline Petrobras & $\mathrm{PN}$ & Petróleo e Gas & Schulz & PN & Veiculos e peças \\
\hline Bombril & $\mathrm{PN}$ & Química & Tupy & $\mathrm{ON}$ & Veiculos e peças \\
\hline Braskem & PNA & Química & Wetzel S/A & $\mathrm{PN}$ & Veiculos e peças \\
\hline Elekeiroz & $\mathrm{PN}$ & Química & & & \\
\hline
\end{tabular}




\subsection{Definição das Variáveis}

Segundo Richardson (1999), as variáveis podem ser classificadas, entre outras formas, segundo o caráter numérico dos elementos em estudo e segundo a posição que ocupam em relação a duas ou mais variáveis. Com relação ao seu caráter numérico, as variáveis podem ser discretas ou contínuas. Uma variável discreta caracteriza-se por ser descrita por valores inteiros, podendo apresentar sequências infinitas. As variáveis contínuas são aquelas que podem assumir qualquer valor em um intervalo de valores. (ANDERSON et al., 2000). Ainda, segundo Richardson (1999, p. 133), não existe nenhuma regra para afirmar que uma variável é inquestionavelmente discreta ou contínua e sua qualidade de categorização é determinada pelo pesquisador, baseada na experiência, senso comum ou qualquer outro meio.

O estudo utilizará diversos indicadores de retorno contábeis e de mercado. Essas variáveis assumem quaisquer valores no universo dos números reais, não somente os números inteiros e, também, não estão limitadas a determinados intervalos. Dessa forma, o trabalho apresenta, somente, variáveis continuas.

As variáveis independentes são as que afetam outras variáveis, mas não precisam estar relacionadas entre si. As variáveis dependentes, por sua vez, são aquelas afetadas ou explicadas pelas variáveis independentes. (RICHARDSON, 1999). Segundo Stevenson (1981), a variável independente é explanatória e a variável dependente é a explicada.

A pesquisa apresentou, como variável dependente, o risco sistemático da ação de uma empresa calculado por meio de seu beta de mercado (os diversos cálculos e conceitos serão explicitados nos próximos parágrafos). Como variáveis independentes foram consideradas 15 extraídas dos relatórios contábeis, classificadas em variáveis de rentabilidade, financeiras e operacionais. Como será explicado a seguir, foram estipuladas 36 versões para cada variável contábil, totalizando, assim, 540 independentes testadas. Também para a variável dependente foram estudadas 6 possíveis proxies como será apresentado na sequência. 


\subsubsection{Variável dependente: beta de mercado}

Como já mencionado no capítulo 2, o beta de mercado corresponde a uma proxy, bastante consagrada, do risco de um título em relação a uma carteira de mercado. “Assim, já que o beta de uma ação mede sua contribuição ao fator risco de uma carteira o beta é a medida teoricamente correta do fator risco da ação.” (WESTON; BRIGHAM, 2000, p. 177).

Ao observar estudos anteriores, esta pesquisa optou por não se limitar a somente uma proxy para o risco, mas, sim, apresentar e trabalhar com seis formas possíveis de proxies do beta de mercado. Antes de apresentar essas formas e seus cálculos é importante salientar a fórmula do cálculo do retorno de uma ação.

$$
\mathrm{R}_{\mathrm{it}_{\mathrm{i}}}=\mathrm{LN} \frac{\left(\mathrm{P}_{\mathrm{it}}\right)}{\left(\mathrm{P}_{\mathrm{it}-1}\right)}
$$

em que: o retorno de um título em um período t é calculado pelo logaritmo neperiano de seu preço pelo preço um período anterior. Os betas de mercado utilizados neste trabalho foram:

1. Beta de mercado 1 (BM1): calculado com base em Ross et al. (1995, p. 248) em que “[...] beta é a covariância do retorno de um título com o retorno do mercado, dividida pela variância do retorno do mercado." Assim, a equação para cálculo do beta foi:

$$
\beta_{i}=\frac{\operatorname{cov}\left(\left(R_{i t}\right),\left(R_{m t}\right)\right)}{\sigma^{2}\left(R_{m t}\right)}
$$

em que: $\mathrm{R}_{\mathrm{it}}$ é a taxa de retorno do ativo i e $\mathrm{R}_{\mathrm{m}}$ a taxa de retorno do ativo de mercado $\mathrm{m}$. Para a variável Beta de mercado 1 (BM1), foi considerado como retorno de mercado um índice calculado a partir da média aritmética das taxas de retorno das ações que constituíram a amostra utilizada neste estudo (IMEDIO). (BEAVER; MANEGOLD, 1975; ODA, 2004; TEIXEIRA; VALLE, 2008).

2. Beta de mercado 2 (BM2): utilizou o mesmo conceito de cálculo do BM1, a única diferença foi o retorno de mercado utilizado. Para o Beta de mercado 2 (BM2), foi considerado o índice Bovespa (IBOV) como retorno do mercado. (ODA, 2004; TEIXEIRA; VALLE, 2008; ILHA et al., 2009). 
3. Beta de mercado 3 (BM3): calculado por intermédio de uma regressão entre os retornos da empresa e os retornos da carteira de mercado média. Para se obter o beta de mercado 3 da ação da empresa, foi utilizada a seguinte equação:

$$
\mathrm{R}_{\mathrm{it}}=\mathrm{a}+\beta_{\mathrm{i}} \quad\left(\mathrm{R}_{\mathrm{mt}}\right)+\mathrm{e}
$$

em que: $(\beta i)$, realizou-se uma regressão linear entre a série de taxas de retornos da ação da empresa $\mathrm{R}_{\mathrm{it}}$ como variável dependente e da série de taxas de retorno do índice de mercado $\left(\mathrm{iR}_{\mathrm{mt}}\right)$ como variável independente, $\mathrm{R}_{\mathrm{mt}}$. (BILDERSEE, 1975; HILL; STONE, 1980; ISMAIL, KIM, 1989; MANDELKER; RHEE, 1984; THOMPSON, 1976).

4. Beta de Mercado 4 (BM4): traz uma das formas de serem calculados betas não alavancados. Utilizado por Bowman (1979), Laveren et al. (1996), Hill e Stone (1980) e Brimble e Hodgson (2007), possui a seguinte fórmula:

$$
\beta_{\mathrm{i} \text { Desalavancado }}=\frac{\mathrm{PL}}{\mathrm{VM}} \quad \beta_{\mathrm{i} \text { Alavancado }}
$$

em que: PL corresponde ao valor de livro do capital próprio e VM o valor de mercado. $\beta_{\text {i Alavancado }}$ corresponde ao beta da ação calculado como BM3, por exemplo.

5. Beta de Mercado 5 (BM5): também, trouxe o conceito de beta desalavancado, calculado a partir da seguinte fórmula, apresentada por Hamada (1971) e Ross et al. (2008):

$$
\beta_{\mathrm{i}_{\text {Desalavancado }}}=\frac{\beta_{\mathrm{i} \text { Alavancado }}}{1+(1-\mathrm{IR}) \frac{\text { DIV }}{\mathrm{PL}}}
$$

em que: IR é a alíquota de IR e corresponde a 34\%, DIV corresponde à dívida onerosa total da empresa.

6. Desvio-Padrão do Retorno: A última variável dependente calculada correspondeu ao desvio-padrão do retorno de um título individual. Apesar de essa ser a medida de risco 
para um título individual e conter risco sistemático e não sistemático, foi utilizada como especulação para saber se betas contábeis estariam relacionados com o risco individual de um ativo.

Por meio do cálculo de cinco formas de betas desenhados em pesquisas antecedentes e uma variável de risco, o propósito foi perceber se os betas contábeis de uma empresa possuem alguma relação com seu risco sistemático. .

\subsubsection{Variáveis independentes}

Quinze variáveis contábeis foram selecionadas como possíveis explicativas do risco determinado pelo mercado. Todas essas variáveis derivaram da teoria e algumas delas já foram testadas em pesquisas anteriores. Elas estão definidas em variáveis de rentabilidade, financeiras e operacionais.

Para testar a relação entre os betas contábeis e o risco sistemático, este trabalho observou a relação com o beta de mercado da média da variável do seu desvio-padrão e de seu beta (covariância da variável com a média das variáveis da amostra pela variância da média das variáveis da amostra). A média da variável foi observada, pois mostra se a magnitude da variável por si só se relaciona com o beta de mercado. O desvio-padrão foi utilizado, pois demonstra a variabilidade dessa variável, conceito básico de risco. O beta da variável foi incluído, pois sugere que a covariância das variáveis pode explicar o risco sistemático melhor do que a média e o desvio-padrão, pelo fato de o risco sistemático depender, em última análise, da relação entre os preços de ação de uma empresa e o índice de preços de todas as firmas tratadas de forma agregada. Foi, então, estipulado o beta contábil para cada variável buscando a relação sistemática entre variáveis contábeis de uma empresa e a variável contábil correspondente para todas as firmas da amostra tratadas de forma agregada.

Assim, para uma variável X foi calculada em:

- Média

$$
\mu_{X i}=\sum \frac{X_{t}+X_{t+1}+X_{t+2} \ldots+X_{t+n}}{n}
$$

- desvio-padrão 


$$
\sigma_{X i}=\sqrt[2]{\frac{\sum\left(X_{1}-\mu_{X i}\right)}{n-1}}
$$

- beta

$$
\beta_{\mathrm{Xi}}=\frac{\operatorname{cov}\left(\left(\mathrm{X}_{\mathrm{t}}\right),\left(\mu_{X C}\right)\right)}{\sigma^{2}\left(\mu_{X C}\right)}
$$

em que: X é a variável escolhida, $n$ corresponde ao número de trimestre totais da amostra e $\mu_{C}$ corresponde ao valor médio de $\mathrm{X}$ na amostra de empresas para o trimestre $\mathrm{n}$.

Também, cada variável foi tratada em sua forma absoluta $X$, padronizada pelo ativo total $\frac{X}{A T}$, padronizada pelo patrimônio líquido, $\frac{X}{P L}$ e padronizada pelo valor de mercado $\frac{X}{V M}$.

Por fim, cada uma foi tratada de forma nominal $X_{t}$, na sua primeira diferença $X_{t+1}-X_{t}$, e em seu valor percentual $\frac{X_{t+1}-X_{t}}{X_{t}}$.

Assim, para a variável $\mathrm{X}$ foram realizadas 36 versões para o cálculo e verificação de associação com o risco sistemático como pode ser visto nas três tabelas a seguir. 
87

Tabela 1 - Versões de betas contábeis

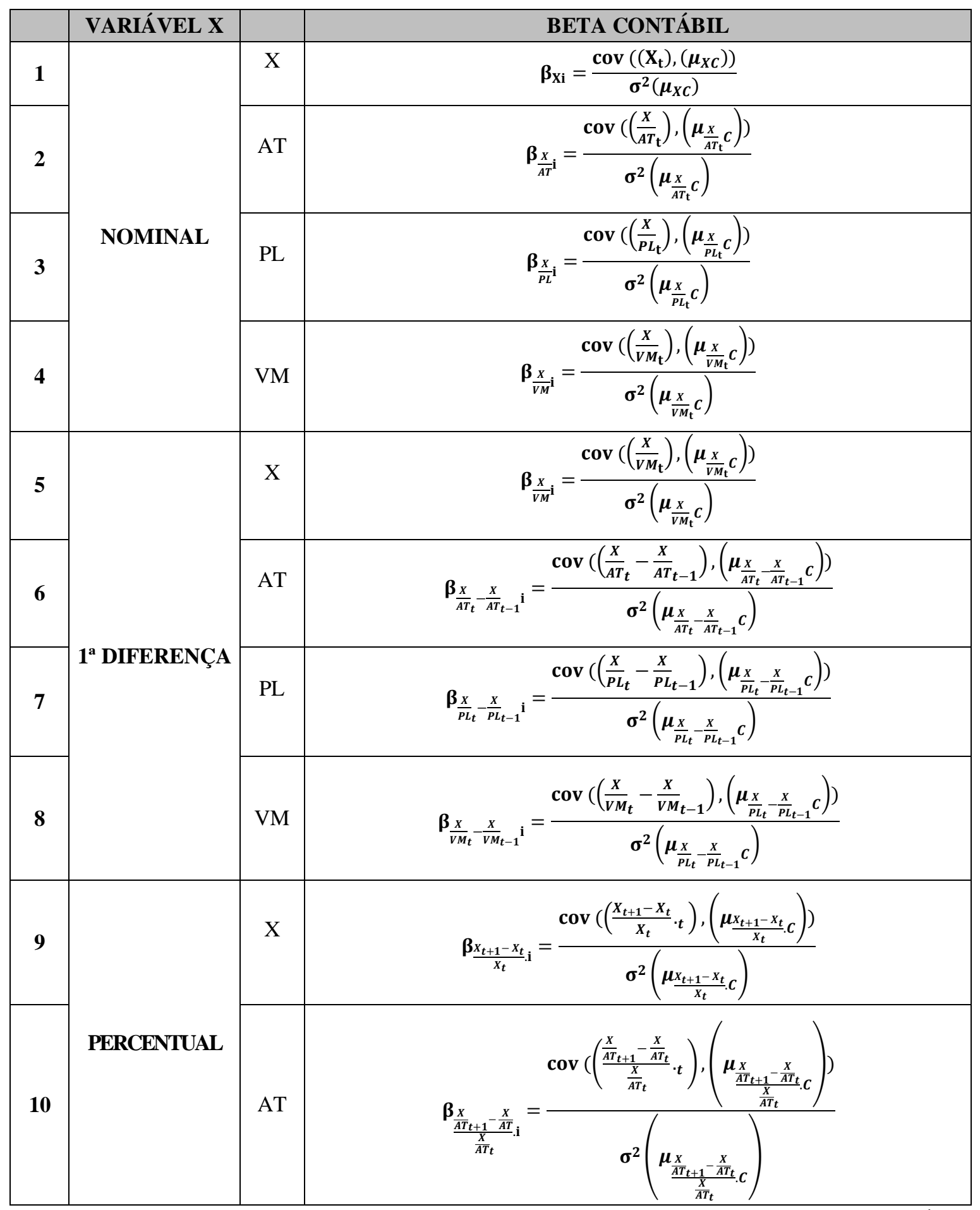

continua 


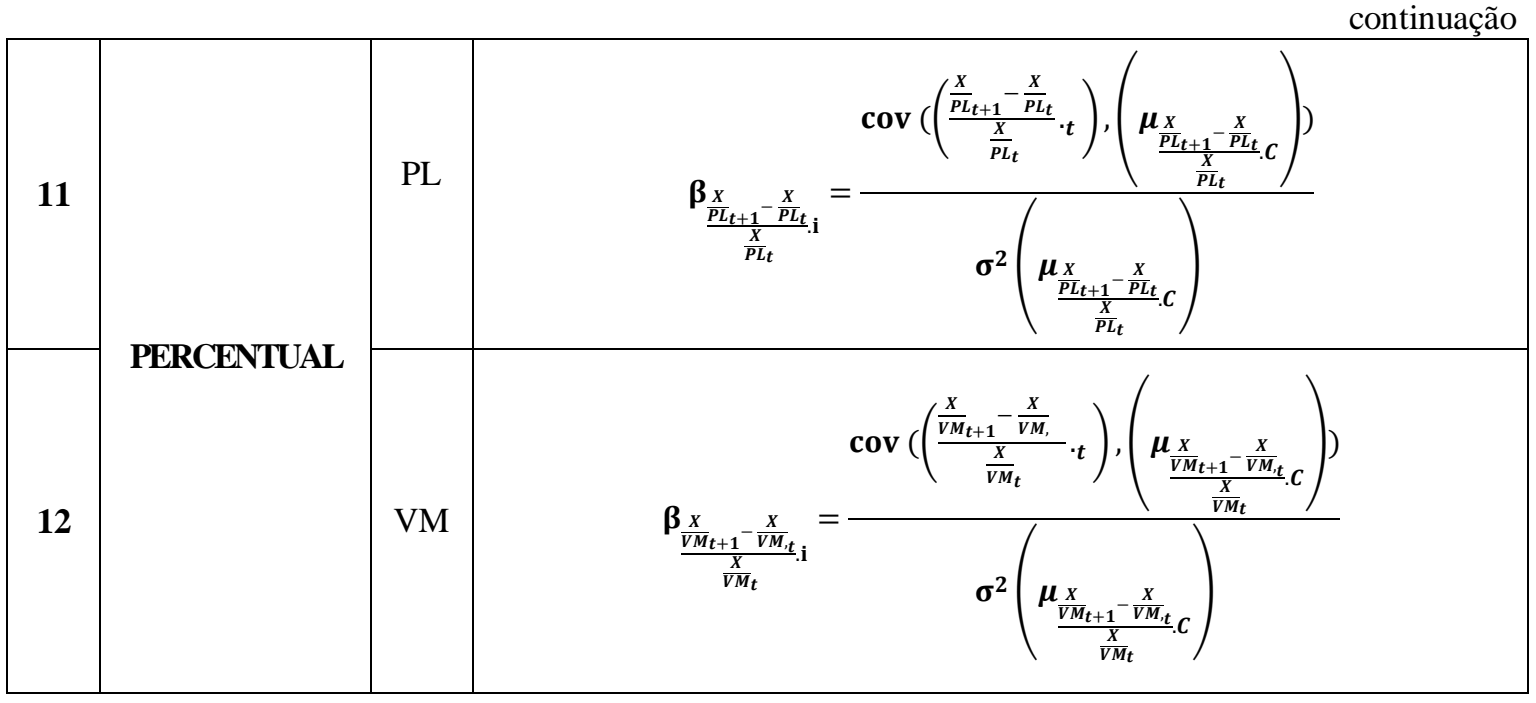

Tabela 2 - Versões de médias de variáveis contábeis

\begin{tabular}{|c|c|c|c|}
\hline & VARIÁVEL X & & MÉDIA DA VARIÁVEL \\
\hline 13 & \multirow{4}{*}{ NOMINAL } & $X$ & $\mu_{X i}=\sum \frac{X_{t}}{n}$ \\
\hline 14 & & AT & $\mu_{\frac{X}{A T} i}=\sum \frac{X}{\frac{X}{A T}}$ \\
\hline 15 & & PL & $\boldsymbol{\mu}_{\frac{X}{P L} i}=\sum \frac{X}{P L_{t}}$ \\
\hline 16 & & $\mathrm{VM}$ & $\mu_{\frac{X}{V M} i}=\sum \frac{\frac{X}{V M_{t}}}{n}$ \\
\hline 17 & \multirow{4}{*}{$1^{\text {a }}$ DIFERENÇA } & $X$ & $\mu_{X_{t}-X_{t-1}{ }^{i}}=\sum \frac{X_{t}-X_{t-1}}{n}$ \\
\hline 18 & & AT & $\mu_{\bar{x}_{t}-\frac{X}{A T_{t-1}} i}=\sum \frac{\frac{X}{A T_{t}}-\frac{X}{A T_{t-1}}}{n}$ \\
\hline 19 & & PL & $\mu_{\bar{X}^{P L_{t}}-\frac{X}{P L_{t-1}} i}=\sum \frac{\frac{X}{P L_{t}}-\frac{X}{P L_{t-1}}}{n}$ \\
\hline 20 & & VM & $\mu_{\frac{X}{V M}_{t}-\frac{X}{V M_{t-1}} i}=\sum \frac{\frac{X}{V M_{t}}-\frac{X}{V M_{t-1}}}{n}$ \\
\hline 21 & PERCENTUAL & $\mathrm{X}$ & $\mu_{\frac{x_{t+1}-X_{t}}{X_{t}} i}=\sum \frac{\frac{X_{t+1}-X_{t}}{X_{t}} \cdot{ }_{t}}{n}$ \\
\hline
\end{tabular}


continuação

\begin{tabular}{|c|c|c|c|}
\hline 22 & \multirow{3}{*}{ PERCENTUAL } & AT & $\boldsymbol{\mu}_{\frac{X}{A T_{t+1}}-\frac{X}{A T_{1}} t_{i}}^{\frac{X}{A T_{t}}}=\sum \frac{\frac{\frac{X}{A T_{t+1}}-\frac{X}{A T_{t}}}{\frac{X}{A T_{t}}} \cdot t_{t}}{n}$ \\
\hline 23 & & PL & 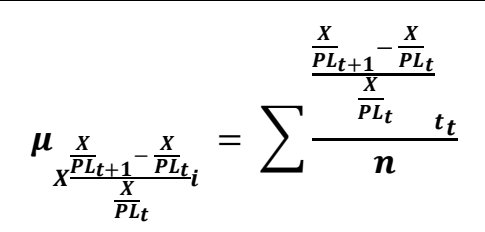 \\
\hline 24 & & VM & $\mu_{\frac{X}{V M_{t+1}-}-\frac{X}{V M_{t_{i}}}}^{\frac{X}{V M_{t}}}=\sum \frac{\frac{\frac{X}{V M_{t+1}}-\frac{X}{V M_{t}}}{\frac{X}{V M_{t}}}{ }_{t}}{n}$ \\
\hline
\end{tabular}

Tabela 3 - Versões de desvio-padrão de variáveis contábeis

\begin{tabular}{|c|c|c|c|}
\hline & VARIÁVEL X & & DESVIO-PADRÃO DA VARIÁVEL \\
\hline 25 & \multirow{4}{*}{ NOMINAL } & $\mathrm{X}$ & $\sigma_{X i}=\sqrt[2]{\frac{\sum\left(X_{1}-\mu_{X i}\right)}{n-1}}$ \\
\hline 26 & & AT & $\sigma_{\frac{X}{A T} i}=\sqrt[2]{\frac{\sum\left(\frac{X}{A T_{1}}-\mu_{\frac{X}{A T} i}\right)}{n-1}}$ \\
\hline 27 & & PL & $\sigma_{\frac{X}{P L} i}=\sqrt[2]{\frac{\sum\left(\frac{X}{P L_{1}}-\mu_{\frac{X}{P L} i}\right)}{n-1}}$ \\
\hline 28 & & VM & $\sigma_{\frac{X}{V M} i}=\sqrt[2]{\frac{\sum\left(\frac{X}{V M_{1}}-\mu_{\frac{X}{V M} i}\right)}{n-1}}$ \\
\hline 29 & \multirow{4}{*}{ 1 $^{\text {a }}$ DIFERENÇA } & $\mathrm{X}$ & $\sigma_{X i}=\sqrt[2]{\frac{\sum\left(\boldsymbol{X}_{\boldsymbol{t}}-\boldsymbol{X}_{\boldsymbol{t}-\mathbf{1}}-\mu_{\boldsymbol{X}_{\boldsymbol{t}}-\boldsymbol{X}_{\boldsymbol{t}-\mathbf{1}} i}\right)}{n-1}}$ \\
\hline 30 & & AT & $\sigma_{X i}=\sqrt[2]{\left.\frac{\sum\left(\frac{X}{A T_{t}}-\frac{X}{A T}_{t-1_{t}}-\mu_{\overline{A T}_{t}}-\frac{X}{\overrightarrow{A T} T_{t-1} i}\right.}{n-1}\right)}$ \\
\hline 31 & & PL & $\sigma_{X i}=\sqrt[2]{\frac{\sum\left(\frac{X}{P L}_{t}-\frac{X}{P L_{t-1}}{ }_{t}-\mu_{\frac{X}{P L_{t}}-\frac{X}{P L L_{t-1}}} i\right)}{n-1}}$ \\
\hline 32 & & VM & $\sigma_{X i}=\sqrt[2]{\frac{\sum\left(\frac{X}{V M}_{t}-\frac{X}{V M_{t-1}}{ }_{t}-\mu_{\frac{X}{V M}_{t}-\frac{X}{V M_{t-1}}}{ }^{i}\right.}{n-1}}$ \\
\hline
\end{tabular}




\begin{tabular}{|c|c|c|c|}
\hline 33 & \multirow{4}{*}{ PERCENTUAL } & $\mathrm{X}$ & $\sigma_{X i}=\sqrt[2]{\frac{\sum\left(\frac{X_{t+1}-X_{t}}{X_{t}} \cdot t_{t}-\mu \frac{x_{t+1}-x_{t}}{X_{t} \cdot t_{t}} t_{t}\right)}{n-1}}$ \\
\hline 34 & & AT & 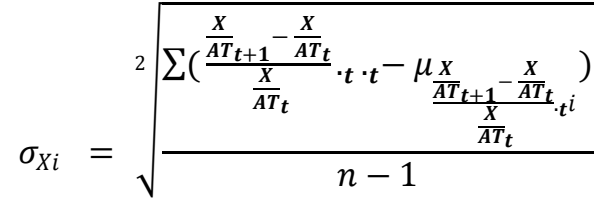 \\
\hline 35 & & PL & 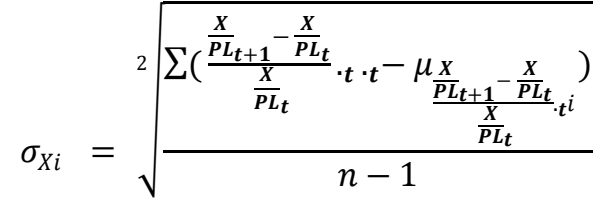 \\
\hline 36 & & VM & 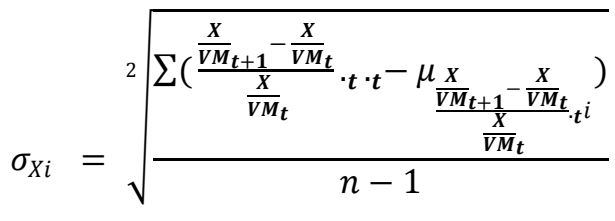 \\
\hline
\end{tabular}

Conforme exposto na fundamentação teórica, o beta contábil representa um análogo ao beta de mercado obtido a partir da utilização de uma série de resultados contábeis no lugar da série de taxas de retorno da ação. (ODA, 2004). Beaver et al. (1970, p. 663) argumentaram que, se o beta de mercado representa o conceito de risco conjuntural, então, o enfoque mais direto para se obter uma associação entre medidas contábeis e risco conjuntural é estimar um beta a partir de retornos contábeis. Pereiro (2002, p. 125) definiu um beta contábil como uma medida que "reflete a sensibilidade dos retornos contábeis de uma empresa em relação aos retornos contábeis do mercado inteiro", acrescentando que os retornos contábeis podem ser calculados a partir de vários indicadores de desempenho do período.

A escolha da utilização dos diferentes enfoques de medidas contábeis deu-se para a verificação de qual deles é mais representativo em relação ao mercado. As diversas medidas de lucro foram testadas a fim de verificar, para, por exemplo, a variável lucro líquido, em qual nível a informação do lucro da empresa se correlaciona com seu risco sistemático.

As padronizações tiveram como objetivo a diminuição dos efeitos de diferenças no tamanho das empresas, assim como nas práticas contábeis adotadas por cada empresa, segundo Ball e Brown (1969). Adicionalmente, a padronização das variáveis contábeis pode ser vista como uma medida de taxa de retorno. Nesse processo, quando se utilizou como denominador das 
medidas de lucro o valor de mercado, obteve-se uma medida do retorno dos investimentos atuais dos acionistas, que, de acordo com Beaver et al. (1975), é uma medida com menos erros se comparada com uma medida contábil, além de refletir reavaliações que poderiam ser ignoradas pelo sistema contábil. O motivo para a utilização da padronização com o total de ativos, de acordo com Gonodes (1973), é produzir um retorno para a empresa inteira ao invés de somente para o patrimônio líquido. E a padronização pelo patrimônio líquido é uma medida de taxa de retorno sobre o investimento em termos estritamente contábeis, segundo Beaver e Manegold (1975).

Foram, também, testadas as variáveis em três níveis: valor nominal, com o intuito de verificar se esses valores refletem diretamente o risco do mercado; diferença nominal calculada pela subtração do valor nominal de um ano pelo valor do ano anterior, já que é consistente com a visão de que converte as variáveis a um processo com uma média relativamente estável, reduzindo a autocorrelação dos resíduos e, possivelmente, levando a uma estimativa mais eficiente dos betas; variação percentual, obtida pela variação percentual de um ano para o seguinte, a fim de constatar se as mudanças percentuais das variáveis afetam o risco sistemático.

Dessa forma, foram estipuladas 36 versões para cada variável contábil e sendo quinze variáveis descritas e detalhadas à frente, tem-se um total de 540 variáveis estudadas para medir sua relação com o risco sistemático.

O estudo pretendeu com isso pesquisar de forma ampla as diversas relações entre o beta contábil e o beta de mercado indicadas em estudos anteriores, além de propor novas possibilidades de associações por meio de primeiras diferenças, variações percentuais, médias e desvios-padrão.

As quinze variáveis utilizadas foram selecionadas de acordo com sua capacidade teórica de representar o desempenho e/ou características de risco da empresa e estão classificadas em variáveis de rentabilidade, financeiras e operacionais, a saber:

\section{Variáveis de Rentabilidade}

1. Lucro líquido: representa o total gerado pelas operações da empresa em um determinado período após apurar todas as suas receitas e despesas. Indica o desempenho 
passado das operações da empresa, mostrando quanto realmente a empresa ganhou ou perdeu em sua atividade em determinado tempo. Por isso, pode ser considerada uma variável pura de retorno, por ser o retorno final que a empresa teve após a contabilização de todos os impostos. Nas pesquisas levantadas pela revisão bibliográfica é a variável mais comumente encontrada como possível explicativa do risco de mercado, como ocorre nos trabalhos iniciais de Ball e Brown (1969), Beaver et al. (1970) e Gonedes (1973). Nesta pesquisa, o lucro líquido foi estudado em 36 versões. Nessas versões, a variável foi observada dividida pelo ativo total, patrimônio líquido e pelo valor de mercado, o que corresponde a medidas consagradas de retorno sobre o investimento. Outra medida bastante estudada que, também, foi observada dentro das 36 versões foi a variabilidade dos lucros. A variabilidade dos lucros representa, em última análise, o risco total que o acionista enfrenta ao investir numa determinada empresa e, de acordo com Beaver et al. (1970), Munhoz (2006) e Rosenberg e McKibben (1973), é a variável contábil mais fortemente relacionada ao risco conjuntural das ações. A variabilidade do lucro foi estudada por meio do seu desvio-padrão e de percentuais de crescimento. (BEAVER et al., 1970; BILDERSEE, 1975; CASTAGNA, MATOLCSY, 1978; ELGERS, 1980; LAVEREN et al., 1997). Como o lucro líquido é uma variável que representa o retorno obtido pela empresa, espera-se que o beta do lucro líquido e os betas dos retornos sobre ativo, patrimônio líquido e valor de mercado caminhem na mesma direção do beta de mercado, ou seja, quando o beta contábil de lucro aumentar o beta de mercado aumentará também. O mesmo ocorre com o desvio-padrão dessa variável que à medida que for maior, maior deverá ser o beta de mercado. Um ponto dáse com as variáveis de médias de lucro líquido as quais, quanto maiores, mais rentável é a empresa e menor será seu risco. Assim, têm-se as seguintes hipóteses:

$\mathbf{H}_{\text {0,1-1 }}$ : Quanto maior o beta contábil de lucro líquido, maior será o beta de mercado. $\mathbf{H}_{\mathbf{0}, \mathbf{1 - 2}}$ : Quanto maior a média de lucro líquido, menor será o beta de mercado. $\mathbf{H}_{\mathbf{0 , 1 - 3}}$ : Quanto maior a variabilidade do lucro líquido, maior será o beta de mercado.

2. EBIT: o Lucro antes dos juros e tributos, também chamado LAJIR ou do original em inglês - EBIT - Earnings Before Interest and Tax), representa uma medida de resultado mais operacional, sem as interferências de despesas financeiras e impostos. (PETTIT; WESTERFIELD, 1972). Por essa razão, é considerada como uma proxy de retornos de uma empresa e é fortemente usada nos modelos de avaliação e previsão de preços. De 
acordo com Ismail e Kim (1989), o EBIT pode ter uma habilidade incremental na explicação da variação do risco, mostrando a importância do fluxo de caixa na formação de expectativas de desempenho da empresa. Assim como o lucro líquido, o EBIT foi estudado em 36 versões algumas delas já levantadas em artigos anteriores como Minardi et al. (2007) e Rodrigues et al. (2008), ROE = EBIT/PL. As hipóteses para o EBIT seguem o mesmo raciocínio do lucro líquido. Assim, têm-se as seguintes hipóteses:

$\mathbf{H}_{\mathbf{0 , 1 - 4}}$ : Quanto maior o beta contábil de EBIT, maior será o beta de mercado.

$\mathbf{H}_{\mathbf{0 , 1 - 5}}$ : Quanto maior a média de EBIT, menor será o beta de mercado.

$\mathbf{H}_{\mathbf{0 , 1 - 6}}$ : Quanto maior a variabilidade do EBIT, maior será o beta de mercado.

3. LAIR: o Lucro antes do Imposto de Renda, também chamado LAIR, foi uma terceira variável de rentabilidade. Representa o resultado gerado após auferir as receitas e despesas financeiras. (ROSENBERG; MCKIBBEN, 1973). Assim, têm-se as seguintes hipóteses:

$\mathbf{H}_{0,1-7}$ : Quanto maior o beta contábil de LAIR, maior será o beta de mercado.

$\mathbf{H}_{\mathbf{0 , 1 - 8}}$ : Quanto maior a média de LAIR, menor será o beta de mercado.

$\mathbf{H}_{\mathbf{0 , 1 - 9}}$ : Quanto maior a variabilidade do LAIR, maior será o beta de mercado.

4. LPA: o Lucro por ação foi a quarta medida de rentabilidade observada neste trabalho. Traz o conceito de lucro por acionista e também se relaciona com o risco conforme o lucro líquido. Assim, têm-se as seguintes hipóteses:

$\mathbf{H}_{\text {0,1-10: }}$ Quanto maior o beta contábil de LPA, maior será o beta de mercado.

$\mathbf{H}_{\mathbf{0 , 1 - 1 1}}$ : Quanto maior a média de LPA, menor será o beta de mercado.

$\mathbf{H}_{\mathbf{0 , 1 - 1 2}}$ : Quanto maior a variabilidade do LPA, maior será o beta de mercado.

\section{Variáveis Operacionais:}

5. RECEITA: as vendas e receitas líquidas são, também, utilizadas como medidas de retorno e desempenho, principalmente em empresas em fase inicial ou naquelas em que medidas de rentabilidade podem ser questionadas. Além de possuir significado para o mercado, em sua forma nominal, as receitas são elementos bastante comuns em diversos indicadores de desempenho, como, por exemplo, no Giro do Ativo (Vendas/Ativo) e 
estão presentes em vários estudos anteriores: Beaver e Manegold (1975), Lev (1974) e Lev e Kunitzky (1974). As hipóteses para a receita são:

$\mathbf{H}_{\text {0,1-13: }}$ Quanto maior o beta contábil de receita, menor será o beta de mercado.

$\mathbf{H}_{\mathbf{0}, \mathbf{1 - 1 4}}$ : Quanto maior a média de Receita, menor será o beta de mercado (pois faturamentos maiores e maiores market shares reduzem o risco).

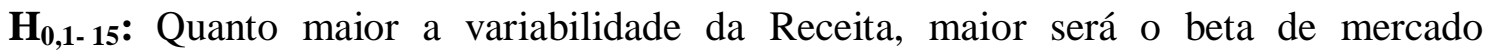
(receitas que oscilam demasiadamente aumentam o risco da empresa)

6. Tamanho: o tamanho da empresas foi mensurado pela média de seu ativo total e pela variação percentual de lucro e receita. Beaver et al. (1970, p. 662) afirmam que "há uma grande crença de que empresas maiores são menos arriscadas do que as menores" e apontam, como evidências, o Dun's Review - de Dun e Bradstreet - que indica uma frequência de falências menor para empresas maiores, e os trabalhos de Horrigan (1966), que mostrou que a principal variável preditiva do rating das dívidas é o tamanho do ativo total, e de Hickman (1958), que mostrou que os ratings dos títulos de dívidas estão associados com a frequência relativa de default. (BOWMAN, 1979; ILHA et al., 2009; THOMPSON, 1976). A hipótese para tamanho é de que $\mathbf{H}_{\mathbf{0}, \mathbf{1}-16}$ : Quanto maior a média de Tamanho, menor será o beta de mercado.

7. Crescimento: a taxa de crescimento foi definida a partir dos ativos totais, receitas e lucros. À semelhança de Beaver et al. (1970), o crescimento foi calculado pelo logaritmo do ativos totais e percentuais de receitas e lucros. A utilização do logaritmo tem a vantagem de diminuir os valores extremos da série - principalmente considerando amostra apresenta algumas empresas de porte muito superior à média - e ainda levar a uma medida de mesma ordem de grandeza das demais variáveis utilizadas no estudo. (BEAVER et al., 1970; BREEN; LERNER, 1973; CASTAGNA; MATOLCSY, 1978). A hipótese para crescimento é que $\mathbf{H}_{\mathbf{0 , 1 - 1 7}}$ : Quanto maior a o beta de crescimento, maior será o beta de mercado.

8. Market to book: ou Valor de Mercado pelo Patrimônio líquido mostra a relação entre o que os investidores estão considerando sobre o valor da empresa e seu custo histórico de aquisição diminuído das depreciações acumuladas e adicionado dos resultados passados acumulados. Segundo Brimble e Hodgson (2007), quanto maior o M/B, maior as expectativas sobre o poder de geração de riqueza da empresa. Devido ao trade off risco 
e retorno, a hipótese para Market to book é que $\mathrm{H}_{0,1-18}$ : Quanto maior o beta Market to book, maior será o beta de mercado.

\section{Variáveis Financeiras:}

9. Dívida onerosa: à medida que as dívidas aumentam, os ganhos dos acionistas se tornam mais voláteis. Dessa maneira, o endividamento pode ser usado como uma medida do risco criado pela estrutura de capital da empresa. Beaver (1966, p. 87), também, apresenta um indício da associação positiva entre endividamento e risco, mostrando que os índices de endividamento foram os que apresentaram a terceira maior capacidade de previsão de dificuldades financeiras entre as analisadas. Dentre os índices de endividamento estudados, o que apresentou maior taxa de acertos foi a dívida total (dívida corrente + dívida de longo prazo + ações preferenciais) sobre o ativo total. $\mathrm{O}$ endividamento foi medido por meio de duas variáveis. A primeira delas é a Dívida onerosa calculada pelo software Economática como sendo Capital de Terceiros - Aplicações Financeiras. As hipóteses para a Dívida onerosa serão:

- $\mathbf{H}_{0,1-19}$ : Quanto maior o beta de Dívida onerosa, maior será o beta de mercado.

- $\mathbf{H}_{\mathbf{0 , 1 - 2 0}}$ : Quanto maior a média de Dívida onerosa, maior será o beta de mercado.

- $\mathbf{H}_{0,1-21}$ : Quanto maior a variabilidade da Dívida onerosa, maior será o beta de mercado.

10. Endividamento: a segunda variável sobre endividamento consiste no total de Capital de Terceiros, formado por Passivo Circulante + Exigível a Longo Prazo. Como todas as variáveis, essa possuiu 36 versões, sendo que sua versão padronizada por Ativo Total, Patrimônio Líquido e Valor de Mercado são consagrados índices de endividamento. A segunda variável contábil mais comumente estudada em relação ao risco sistemático é o endividamento. (BILDERSEE, 1975; ELGERS, 1980; HAMADA, 1971; HILL; STONE, 1980; MANDELKER; RHEE, 1984). Assim como para a Dívida onerosa as hipóteses para endividamento serão:

- $\mathbf{H}_{\mathbf{0 , 1 - 2 2}}$ : Quanto maior o beta de Endividamento, maior será o beta de mercado.

- $\quad \mathbf{H}_{\mathbf{0 , 1 - 2 3}}$ : Quanto maior a média de Endividamento, maior será o beta de mercado.

- H,1-24: Quanto maior a variabilidade do Endividamento, maior será o beta de mercado. 
11. Liquidez: Beaver et al. (1970, p. 662) argumentam que ativos líquidos têm um retorno menos volátil que os ativos não circulantes. No limite, o caixa pode ser visto como um ativo "livre de risco", com retorno igual a zero e volatilidade zero (ignorando o risco inflacionário). (ODA, 2004). A medida utilizada, neste estudo, foi Liquidez Geral calculada por AC/PC. Espera-se que:

- $\quad \mathbf{H}_{\mathbf{0 , 1 - 2 5}}$ : Quanto maior o beta de Liquidez, menor será o beta de mercado.

- $\quad \mathbf{H}_{\mathbf{0 , 1 - 2 6}}$ : Quanto maior a média de Liquidez,menor será o beta de mercado.

- $\quad \mathbf{H}_{\mathbf{0 , 1 - 2 7}}$ : Quanto maior a variabilidade da Liquidez, maior será o beta de mercado.

12. Capital de Giro: assim como a liquidez, apresenta uma relação com o risco de uma empresa. Quanto maior o capital de Giro significará que maior será a quantidade de recursos próprios e de terceiros de longo prazo investido em operações de curto prazo, o que significa uma folga financeira para as operações e contribui para a redução do risco da empresa. Em outra ponta, quanto menor for o capital de giro da empresa e sendo ele muitas vezes negativo, significará que existem recursos de terceiros de curto prazo investidos em ativos de longo prazo e/ou permanentes, o que configura uma situação de alto risco. Assim, pretende-se que:

- $\mathbf{H}_{\mathbf{0 , 1 - 2 8}}$ : Quanto maior o beta de Capital de Giro, menor será o beta de mercado.

- $\mathbf{H}_{\mathbf{0 , 1 - 2 9}}$ : Quanto maior a média de Capital de Giro, menor será o beta de mercado.

- $\mathbf{H}_{\mathbf{0 , 1 - 3 0}}$ : Quanto maior a variabilidade do Capital de Giro, maior será o beta de mercado.

13. Cobertura de Juros: o grau de cobertura dos juros mede a relação entre o Lucro Líquido dividido pelas Despesas Financeiras de uma empresa no mesmo período. Quanto maior for essa variável maior será a capacidade de pagamento de uma empresa com relação a suas dívidas, o que contribui para a redução do risco. Assim, as hipóteses são:

- $\quad \mathbf{H}_{\text {0,1-31 }}$ : Quanto maior o beta de Cobertura de juros, menor será o beta de mercado.

- $\quad \mathbf{H}_{\mathbf{0 , 1 - 3 2}}$ : Quanto maior a média de Cobertura de juros, menor será o beta de mercado. 


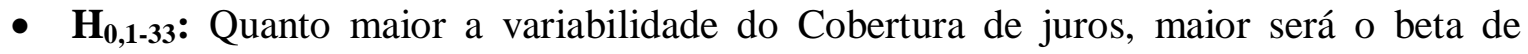
mercado.

14. Grau de Alavancagem Operacional: conforme apresentado na fundamentação teórica, o grau de alavancagem operacional (GAO) de uma empresa representa a intensidade com que uma variação em sua receita afeta o seu resultado operacional (LAJIR). (COSTA, 2007; LEV, 1974; MANDELKER; RHEE 1984; ROSENBERG; McKIBBEN, 1973; TEIXEIRA; VALLE, 2008). Sendo definido como EBIT/Receita Líquida (WESTON; BRIGHAM, 2000, p. 352). Segundo a teoria, quando a receita afeta, fortemente, o EBIT, aponta que a empresa possui predominância de custos fixos. A supremacia de custos fixos eleva o risco das empresas.

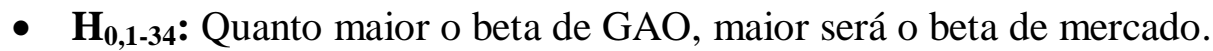

- $\mathbf{H}_{\mathbf{0 , 1 - 3 5}}$ : Quanto maior a média de GAO, maior será o beta de mercado.

- $\quad \mathbf{H}_{\mathbf{0 , 1 - 3 6}}$ : Quanto maior a variabilidade do GAO, maior será o beta de mercado.

15. Grau de Alavancagem Financeira: o grau de alavancagem financeira (GAF) de uma empresa representa a intensidade com que uma variação em seu resultado operacional (LAJIR) afeta o seu Lucro Líquido (LL), sendo definido como (WESTON; BRIGHAM, 2000, p. 678): LL/EBIT. Quanto maior for a relação LL/EBIT indica que menor é a quantidade de despesas financeiras ante o lucro operacional, o que contribui para a redução do risco. Assim:

- $\mathbf{H}_{\mathbf{0 , 1 - 3 7}}$ : Quanto maior o beta de GAF, maior será o beta de mercado.

- $\mathbf{H}_{\mathbf{0 , 1 - 3 8}}$ : Quanto maior a média de GAF, maior será o beta de mercado.

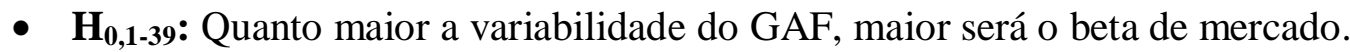

\subsection{Proceder Metodológico}

Conforme a revisão bibliográfica apresentada nos capítulos 2 e 3, existem muitas maneiras de se tentar detectar e compreender a relação existente entre as variáveis contábeis e o beta de mercado. Essa relação aparece mais estudada por meio da utilização de técnicas de regressão múltipla e correlação. A regressão objetiva prever os valores de uma variável dependente, 
com base nos valores de uma variável independente (regressão linear) ou de várias variáveis independentes (regressão múltipla). Já a correlação avalia, apenas, o grau de associação entre duas variáveis.

Para satisfazer o objetivo de "verificar se os betas contábeis de uma empresa possuem relação com seu risco sistemático, calculado através do beta de mercado, para as ações negociadas na BM\&FBOVESPA", foram, primeiramente, analisados o nível de associação entre betas contábeis e betas de mercado.

O primeiro passo foi, então, aplicar a ferramenta estatística de Correlação para as 6 variáveis de betas de mercado com relação a 540 variáveis contábeis de betas contábeis, média e desvio-padrão. Feito isso, o segundo passo foi selecionar as variáveis que obtiveram uma maior relação com betas de mercado e analisar se podem explicar o beta de mercado. Por intermédio da ferramenta de Dados em Painel foram analisadas quais variáveis são capazes de explicar e antecipar o comportamento do beta de mercado, ou seja, do risco sistemático.

Este trabalho, teve também como objetivo específico verificar se os betas contábeis e betas de mercado possuem os mesmos componentes, podendo o beta contábil cooperar na estimação do risco de uma empresa. Para isso, este trabalho se inspirou nos estudos de Ball et al. (2009) e Connor e Korajczyk (1987). Por meio de ferramenta de Análise de Componentes Principais foi possível constatar se existem ou não componentes comuns entre o beta contábil e o beta de mercado. Por fim, para as variáveis que possuíssem componentes principais, foi aplicada a ferramenta estatística de Correlação Canônica com o intuito de saber se os componentes estão correlacionados.

Nos próximos quatro tópicos, estão expostos os conceitos e a descrição operacional dessas quatro técnicas.

\subsubsection{Correlação}

Segundo Stevenson (1981), o objetivo de uma correlação é determinar a força do relacionamento entre duas observações emparelhadas. O coeficiente de correlação de Pearson mede "o grau de dispersão conjunta e de associação linear entre duas variáveis aleatórias." 
(FONSECA; MARTINS, 1996, p. 57). O termo correlação significa, literalmente, correlacionamento, pois indica até que ponto os valores de uma variável estão relacionados com os de outra. Conforme Stevenson (1981, p. 368), essa técnica é válida quando se verificam duas condições:

(1) Tanto x como y são variáveis aleatórias contínuas, isto é, ao contrário da análise de regressão, não se aceita selecionar certos valores de $\mathrm{x}$ e depois avaliar $\mathrm{y}$ : tanto y como $\mathrm{x}$ devem variar livremente, isto é, serem considerados "como são".

(2) A distribuição de freqüência conjunta, isto é, a distribuição de valores dos pares x, y, é normal. É o que se chama distribuição normal bivariada.

$\mathrm{O}$ valor desse coeficiente varia entre -1 e +1 , sendo que, quanto maior o valor absoluto, maior é a associação entre as variáveis. Variáveis com correlação positiva tendem a mover-se no mesmo sentido, ou seja, valores altos (acima da média) da primeira variável, normalmente, correspondem a valores altos na segunda variável. Por outro lado, correlação negativa indica que, quando uma das variáveis se encontrasse acima da média, a outra, normalmente, estaria abaixo. (ODA, 2004).

Nesta pesquisa, a exemplo dos testes realizados por Ball e Brown (1969) e Beaver et al. (1970), o coeficiente de correlação de Pearson foi empregado para 6 variáveis dependentes e para 468 independentes, totalizando 2.808 coeficientes de correlação para verificar se existe associação entre variáveis.

\subsubsection{Dados em painel}

Também chamados de dados combinados, combinações de séries temporais e de dados em cortes transversal, dados longitudinais, análise histórica de eventos ou análise de corte, os dados em painel correspondem à utilização conjunta das metodologias de cross section e séries temporais, denominada de pooling, cuja finalidade é poder permitir ao pesquisador maior flexibilidade para modelar diferenças entre os comportamentos individuais (GUJARATI, 2006).

Gujarati (2006) explica que, nas séries temporais, se observam os valores de uma ou mais variáveis ao longo do tempo e nas regressões ou cortes transversais, observam-se dados para uma ou mais variáveis, para várias unidades ou unidades amostrais no mesmo período. Nos dados em painel, a mesma unidade de corte transversal é acompanhada ao longo do tempo, 
em síntese, dados em painel têm uma dimensão espacial e outra temporal, sendo uma junção de série temporal com cross-section. Verbeek (2000, p. 310) destaca a vantagem dos dados em painel em relação à análise de séries temporais ou cross-section:

\begin{abstract}
Uma vantagem importante dos dados de painel em comparação com séries temporais ou regressão é que ela permite a identificação de certos parâmetros ou perguntas, sem a necessidade de fazer suposições restritivas. Por exemplo, torna possível analisar as mudanças em um nível individual. Considere uma situação em que o consumo médio aumenta $2 \%$ de um ano para outro. dados em painel pode identificar se esse aumento é o resultado de, por exemplo, um aumento de $2 \% \mathrm{em}$ todos os indivíduos da amostra ou um aumento de $4 \%$ para apenas metade da amostra, enquanto a outra metade não apresenta nenhuma mudança ${ }^{4}$. (tradução nossa)
\end{abstract}

O modelo de dados em painéis é caracterizado pela junção de repetidas observações em dados de corte de uma mesma unidade coletadas ao longo de um período de tempo. (FERREIRA, 2006). Dessa forma, modelos de previsão e regressão que antes eram feitos, considerando-se, apenas, a dimensão “i” do indivíduo, também levarão a dimensão do tempo " $\mathrm{t}$ ” de cada indivíduo em consideração. Na metodologia de dados em painel, como a variável dependente varia em duas dimensões distintas (tempo e unidade), os estimadores são geralmente mais apurados do que em outras fontes, Verbeek (2000).

Os dados em painel combinam séries temporais com cortes transversais, assim, aumentam, consideravelmente, o tamanho da amostra e é o método mais indicado para estudar a dinâmica da mudança. (GUJARATI, 2006). Dessa maneira, a metodologia de dados em painel possui estimadores mais eficientes do que no caso de uma série de dados seccionais independentes, na qual os indivíduos são selecionados de uma dada população para cada período e, portanto, diferente de uma análise que olha para cada um dos indivíduos durante todo o período. Ainda, segundo Gujarati (2006), os dados em painel podem enriquecer a análise empírica de forma que seria impossível se se restringisse aos dados de corte transversal ou em séries temporais isoladamente.

Greene (1997) demonstra que, em termos gerais, uma abordagem genérica para essa metodologia pode ser apresentada por meio de um modelo de regressão linear da seguinte forma:

\footnotetext{
4 "An important advantage of panel data compared to time series or cross-sectional data sets is that it allows identification of certain parameters or questions, without the need to make restrictive assumptions. For example, panel data make it possible to analyse changes on an individual level. Consider a situation in which the average consumption level rises with $2 \%$ from one year to another. Panel data can identify whether this rise is the result of, for example, an increase of $2 \%$ for all individuals or an increase of $4 \%$ for approximately one half of the individuals and no change for the other half."
} 


$$
Y_{i t}=\alpha+\beta X_{i t}+e_{i t}
$$

em que:

$Y_{i t}$ é a variável dependente do i-ésimo indivíduo cross-section no tempo $t$;

$\alpha$ é o intercepto individual de cada indivíduo cross-section;

$\beta$ é o vetor de coeficientes das variáveis independentes;

$X_{i t}$ é um vetor com $k$ variáveis independentes para o $i$-ésimo indivíduo cross-section no tempo $t$;

$e_{i t} e ́$ um termo de erro aleatório.

O intercepto diferenciado para cada um dos indivíduos permite ao pesquisador maior flexibilidade para modelar as diferenças de comportamento que possam existir entre eles. Tal efeito individual é dado na equação acima pelo termo $\alpha 1(=\alpha+\mu 1)$ que é constante ao longo do tempo t e específico para cada indivíduo. No caso de $\alpha$ ser o mesmo para todas as empresas, o método dos mínimos quadrados ordinários fornece estimativas eficientes e consistentes para estimar $\alpha$ e $\beta$. Caso o efeito individual seja diferente entre as empresas, a especificação de dados em painel apresenta duas hipóteses alternativas para se modelar o comportamento heterogêneo dos que pertencem à unidade, sendo eles: o Modelo de Efeitos Fixos e o Modelo de Efeitos Aleatórios. (FERREIRA, 2006).

\subsubsection{O modelo de efeitos fixos}

O modelo de efeitos fixos de dados em painel é uma forma de levar em conta a "individualidade" de cada empresa ou cada unidade de corte transversal, fazendo-se variar o intercepto para cada empresa e considerando-se que os coeficientes angulares são constantes entre as empresas. Trata-se, simplesmente, de um modelo de regressão linear no qual os interceptos variam segundo as unidades individuais (empresas), embora admita que os coeficientes $\beta$ são idênticos para todos os indivíduos. A distinção entre os interceptos é alcançada por meio da inclusão de variáveis dummies para cada unidade seccional, formando, assim, um conjunto com $\mathrm{N}$ variáveis dummies no modelo. (FERREIRA, 2006).

Então, na presença de efeitos fixos inerentes ao indivíduo, a amostra longitudinal permitirá decompor o erro de modelagem de cada unidade amostral $Y_{i t} t$ em uma componente fixa $C_{i t}$, 
que é a porção do erro inerente ao indivíduo e invariante no tempo e uma nova componente de erro aleatório $U_{i t}$, de menor magnitude, gerando uma previsão que seja consistente por isolar o efeito de variáveis omitidas. Matematicamente, o modelo estrutural de um painel de dados com efeitos fixos é definido como:

$$
Y_{i t}=\alpha+\beta X_{i t}+C_{i t}+U_{i t}
$$

em que:

$Y_{i t}$ é informação da evolução temporal da variável dependente para todos os indivíduos da amostra;

$X_{i t}$ é a informação da evolução temporal das variáveis independentes para todos os indivíduos da amostra;

$C_{i t}$ efeito fixo no tempo e específico do indivíduo, ou seja, o modelo terá a presença de "n" efeitos fixos (um para cada indivíduo da amostra) e $U_{i t}$ o erro aleatório do modelo.

Observe que o subscrito "i" se refere à unidade amostral e que o subscrito "t" se refere à evolução temporal. A metodologia de dados em painel tratará, simultaneamente, toda essa amostra, que é composta de " $i$ " séries de tempo com " $t$ " observações para cada uma delas. Repare que o efeito fixo $C_{i t}$ não é estimado em um modelo tradicional do tipo cross-section, mas que é possível supor sua presença ao admitir que os erros são correlacionados.

\subsubsection{O modelo de efeitos aleatórios}

Uma alternativa ao modelo de efeitos fixos é o modelo de correção dos erros ou modelo dos efeitos aleatórios. Nesse, pressupõe-se que o intercepto de uma unidade individual é uma extração aleatória de uma população muito maior com um valor médio constante. (GUJARATI, 2006). Esse modelo pode ser representado pela seguinte equação, segundo Verbeek (2000):

$$
Y_{i t}=\mu+\alpha+\beta X_{i t}+e_{i t}
$$

tal que: $\mu+e_{i t}$ representa um termo de erro que é formado por dois componentes: um componente individual específico, que não varia no tempo, e um componente de nota 
(remainder) que, supostamente, não é correlacionado ao longo do tempo. Isso significa que toda correlação do termo de erro ao longo do tempo é atribuída aos efeitos individuais $\mu$. Pressupõe-se que $\mu+e_{i t}$ são mutuamente independentes de $X_{i t}$. Desse modo, o método de estimação dos mínimos quadrados ordinários torna-se ineficiente. Para esses casos, utilizamse os estimadores dos mínimos quadrados generalizados ou GLS (Generalized Least Squares). (FERREIRA, 2006).

Como argumenta Wooldridge (2005), em muitas aplicações, toda a razão do uso de dados em painel é permitir que o efeito não observado $e_{i t}$ se correlacione com as variáveis independentes. Pressupõe-se que $e_{i t}$ e $X_{i t}$ não estão correlacionados, o modelo de efeitos aleatórios pode ser o adequado, mas, se se espera que estejam correlacionados, então, o modelo de efeitos fixos pode ser o indicado. (GUJARATI, 2006). O modelo de Efeitos Fixos é mais exigente em termos de grau de liberdade perdidos. Além disso, quando o modelo de Efeitos Aleatórios é válido, isso significa que a estimativa, por meio do modelo de Efeitos Fixos, produzirá estimativas mais consistentes na identificação dos parâmetros.

Testes colocar

\subsubsection{Análise de componentes principais}

$\mathrm{Na}$ perspectiva de atender ao objetivo secundário deste trabalho de "verificar se os betas contábeis e betas de mercado possuem os mesmos componentes", foram utilizadas as ferramentas de Análise de Componentes Principais para os betas contábeis apontados pela análise de dados em painel como variáveis explicativas do beta de mercado. Com isso foi possível constatar se existem ou não componentes comuns entre o beta contábil e o beta de mercado. Por fim, para as variáveis que possuíssem componentes principais, foi aplicada a ferramenta estatística de Correlação Canônica mais bem explicada no tópico seguinte.

A Análise de Componentes Principais é uma técnica estatística que busca, mediante avaliação de um conjunto de elementos, a identificação de dimensões de variabilidade comuns existentes em um conjunto de fenômenos. O intuito é desvendar estruturas existentes, mas que não são observáveis diretamente. Cada uma dessas dimensões de variabilidades comuns recebe o nome de FATOR. (CORRAR et al., 2009).

Seu princípio é que altas correlações entre as variáveis geram agrupamentos que configuram os fatores. O fator comum vem explicar o porquê da alta correlação entre as variáveis. A 
Análise dos Componentes Principais parte do pressuposto de que a correlação entre as variáveis surge porque essas variáveis compartilham ou estão relacionadas com o mesmo fator. (CORRAR et al., 2009; HAIR et al., 1998).

Assim, na Análise de Componentes Principais e na Análise Fatorial, as correlações entre empresas são explicadas por dimensões escondidas (fatores). Ao desvendar os fatores, a AF acaba por simplificar estruturas complexas de relacionamento. A ferramenta busca o entendimento do que está por trás desses indicadores, ou seja, desvenda, pela análise das variáveis observáveis, a existência de variáveis não observáveis. (CONNOR; KORAJCZYK, 1987; CORRAR et al., 2009).

A Análise de Componentes Principais é uma técnica de interdependência, ou seja, as variáveis são analisadas com o intuito de maximizar o poder de explicação do conjunto de variáveis. Cada variável é explicada levando em consideração todas as outras, incluindo-se as variáveis latentes (Fatores-Fn). O intuito das técnicas de interdependência não é o de prever o valor da variável dependente e, sim, identificar uma estrutura de relacionamentos que permita a explicação das variações ocorridas nas variáveis analisadas. (CORRAR et al., 2009).

Resumidamente: a Análise de Componentes Principais e Fatorial tem como um de seus principais objetivos tentar descrever um conjunto de variáveis originais por meio da criação de um número menor de dimensões ou fatores, que sejam comuns e endógenos a essas variáveis. (CONNOR, 1995).

\section{Modelo matemático:}

A AF avalia a correlação existente entre um grande número de variáveis e identifica a possibilidade de essas variáveis serem agrupadas por fatores comuns. É o mesmo que dizer que a AF avalia a possibilidade de agrupar i variáveis $\left(\mathrm{X}_{1}, \mathrm{X}_{2}, \mathrm{X}_{3}, \mathrm{X}_{4} \ldots\right)$ em um número menor de $\mathrm{j}$ fatores $\left(\mathrm{F}_{1}, \mathrm{~F}_{2}, \mathrm{~F}_{3}, \mathrm{~F}_{4} \ldots\right)$. $\mathrm{O}$ trabalho de Spearman (1904, apud CORRAR et al. 2009) apresentou o conceito de Análise de Componentes principais da seguinte forma:

$$
X_{i}=\alpha_{i} F+e_{i}
$$

em que:

$X_{i}$ é a variável i analisada; 
$F$ é o fator;

$e_{i}$ é o erro;

$\alpha_{i}$ é uma constante.

A fórmula representa que uma variável padronizada, de média zero e variância igual a $1, X_{i}$ é explicada por uma constante que multiplica um fator F. Entretanto, as variáveis não são possíveis de se explicar em sua forma completa e essa diferença é atribuída ao erro $e_{i}$. Por isso, uma variável poderá ser expressa por suas cargas fatoriais, ou seja, valores que medem o grau de correlação entre a variável original e os fatores, os fatores comuns não relacionados entre si e o erro que é a parcela exclusiva da variável e não pode ser explicada pelos fatores comuns:

$$
X_{i}=\alpha_{i 1} F_{1}+\alpha_{i 2} F_{2}+\alpha_{i 3} F_{3}+\alpha_{i 4} F_{4}+\ldots \alpha_{i n} F_{n}+e_{i}
$$

Essa mesma fórmula, também, pode ser expressa:

$$
F_{i}=\omega_{i 1} X_{1}+\omega_{i 2} X_{2}+\omega_{i 3} X_{3} \ldots+\omega_{i n} X_{n}
$$

ou

$$
F_{i}=\sum_{t=1}^{i} \omega_{i n} X_{n}
$$

em que: $F_{i}$ são os fatores comuns não relacionados, $\omega_{\text {in }}$ são os coeficientes dos escores fatoriais e $X_{n}$ são as variáveis originais envolvidas no estudo. O escore fatorial é um número resultante da multiplicação dos coeficientes $\omega_{\text {in }}$ pelo valor das variáveis. 
Corrar et al. (2009, p. 79) explicam que:

O fator é o resultado do relacionamento linear entre as variáveis e que consegue explicar uma parcela de variação das variáveis originais. Em outras palavras, significa dizer que a AF agrupa algumas variáveis observáveis (por exemplo, liquidez corrente, seca e geral) em um fator não diretamente observável (liquidez) e que por uma relação linear entre as variáveis pode-se chegar à conclusão de que as variáveis que formam o fator (liquidez) têm em comum $98 \%$ de suas variações. [...] Isto nos induz ao raciocínio de que, conhecendo o grau de relacionamento entre as variáveis, seria possível determinar o que realmente é importante ser medido e acompanhado, bem como o que pode ser inferido ou projetado a partir do controle de apenas algumas variáveis.

Para a realização da AF é necessário: escolher o método de extração de fatores a ser utilizado; escolher o tipo de análise a ser utilizada; determinar como será feita a escolha dos fatores e aumentar o poder de explicação da AF.

Quanto ao método, os mais utilizados são: a Análise de Componentes Principais (ACP) e a Análise Fatorial Comum. (CORRAR et al., 2009; KIM; MUELLER, 1978).

O método mais comum é esse que considera a variância total nos dados, pelo qual se procura uma combinação linear de forma que a máxima variância seja explicada por essa combinação. Em seguida, retira-se a variância já explicada no passo anterior e procura-se uma nova combinação de variáveis que explique a maior combinação de variáveis restantes e assim por diante. Esse procedimento resulta em fatores ortogonais, ou seja, não correlacionados entre si. (CORRAR et al., 2009; KIM; MUELLER, 1978;).

Hair et al. (1998, p.100) comentam que esse método deve ser escolhido quando:

[...] o objetivo é de que um número mínimo de fatores venha a explicar a parcela máxima da variância existente nas variáveis originais e quando o conhecimento prévio das variáveis sugira que a variância específica e o erro representem uma parcela pequena na explicação da variância total das variáveis [...] a variância pode ser dividida em: comum, específica e erro. A variância comum é a compartilhada entre as variáveis; a específica é de exclusividade de uma variável não sendo possível identificá-la em nenhuma outra variável; e o erro é a variância causada por fatores aleatórios (incertos).

Os fatores são estimados com base, apenas, na variância comum desconsiderando a parcela específica e a parcela de erro. É indicada para pesquisadores que já possuem um bom conhecimento das variáveis analisadas e têm como principal objetivo a análise de estruturas subjacentes de relacionamento entre as variáveis. (CORRAR et al., 2009; KIM; MUELLER, 1978). 
Neste trabalho, utilizou-se como método de extração de fatores a Análise de Componentes Principais, pois o objetivo foi o de extrair dos diversos dados contábeis (Lucro Líquido/Ativo, EBITDA/Ativo e Fluxo de Caixa/Ativo) e valor a máxima variância explicada por essa combinação.

Quanto à análise das variáveis, existem as mais utilizadas; R-mode factor analysis e Q-mode factor analysis e, ainda, as menos usuais: O-mode factor analysis, T-mode factor analysis e Smode factor analysis.

- $\quad R$-mode factor analysis: é utilizada quando o pesquisador busca identificar estruturas subjacentes capazes de serem percebidas apenas pela construção dos relacionamentos entre diversas variáveis. Por exemplo, quando, em uma análise, o pesquisador quer entender diversos indicadores econômico-financeiros das empresas que representam o índice Bovespa e quer agrupá-los em fatores ortogonais não correlacionados que possam resumir e melhor entender esses indicadores. (CORRAR et al., 2009). A Figura 1, a seguir, representa sua estruturação:

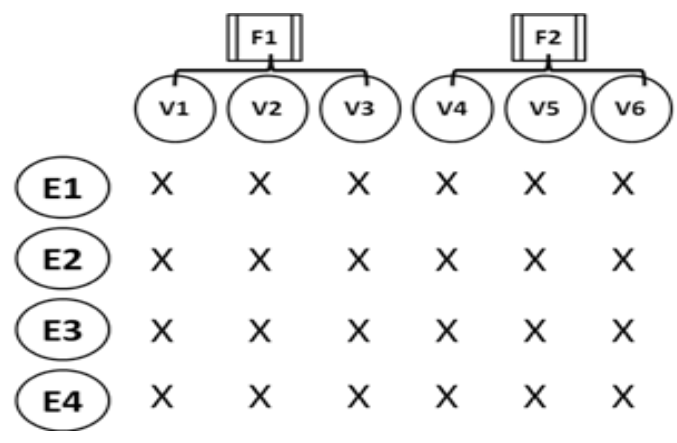

Figura 1: R-mode factor analysis

Fonte: Corrar et al., 2009, p. 82

- $Q$-mode factor analysis: é utilizada quando o pesquisador está interessado em criar agrupamento dos casos. Um exemplo seria, o caso dos indicadores econômicofinanceiros, se o pesquisador desejasse agrupar as empresas com desempenhos similares quanto a esses indicadores. A Figura 2 representa sua estruturação: 


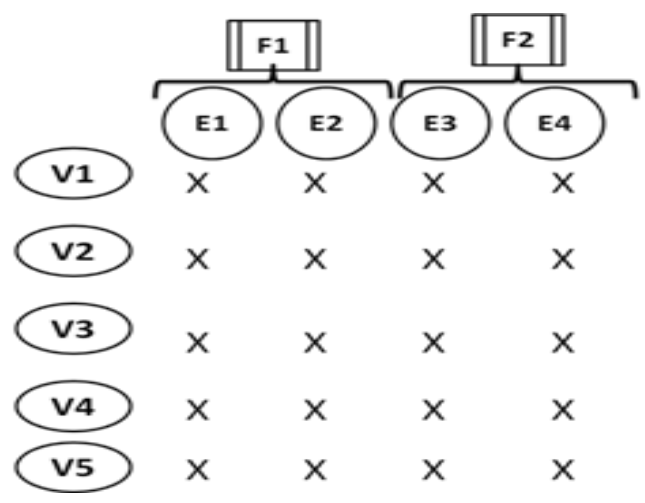

Figura 2: Q-mode factor analysis

Fonte: Corrar et al., 2009, p. 83

- $\quad$ O-mode factor analysis: é utilizada quando o pesquisador está interessado em analisar apenas E1 por meio de diversas variáveis no decorrer de vários anos. Nesse módulo, o pesquisador estará realizando uma análise de série temporal, na intenção de criar relacionamentos entre os diversos anos de um caso. (CORRAR et al., 2009). No exemplo das empresas e indicadores financeiros, é possível utilizar essa análise para apenas uma empresa e seus indicadores financeiros durante vários anos. A Figura 3, a seguir, representa sua estruturação:

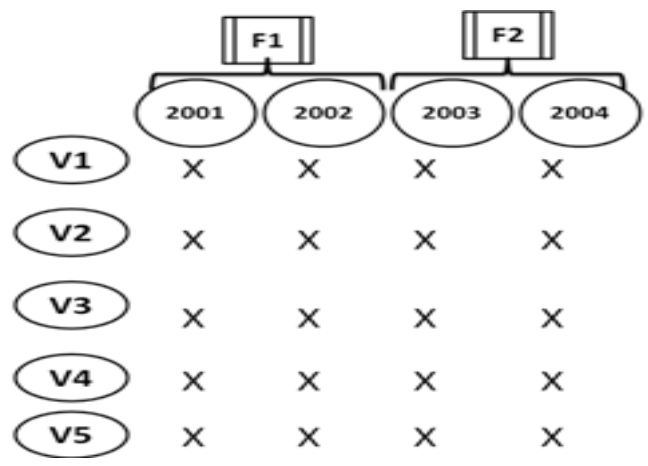

Figura 3: O-mode factor analysis

Fonte: Corrar et al., 2009, p. 84

- T-mode factor analysis: é utilizada quando o pesquisador está interessado em saber se o comportamento de uma variável pode ser relacionado com algum tipo de variação entre as empresas analisadas. Avalia-se somente uma variável no decorrer dos anos, com o objetivo de se agrupar os diversos anos que tiveram comportamento semelhantes da variável. (CORRAR et al., 2009). Seguindo o exemplo anterior, seria avaliar apenas a variável ROA (Return On Asset), durante diversos anos em várias empresas, com o 
objetivo de consolidar os anos em que essa variável apresentou comportamento semelhantes. A Figura 4 representa sua estruturação:

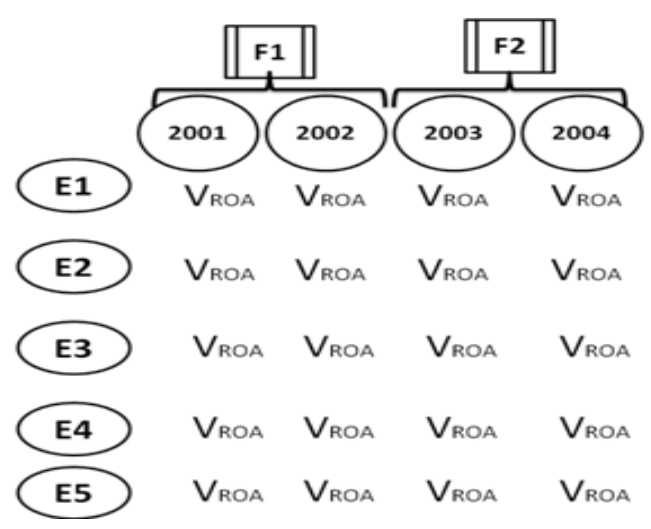

Figura 4: T-mode factor analysis

Fonte: Adaptada de Corrar et al., 2009, p. 85

- $\quad$-mode factor analysis: é utilizada quando o pesquisador está interessado em analisar, com base em uma variável especial, se é possível o agrupamento de diversas empresas ou encontrar fatores que resumam a variação comum entre elas com relação à variável estudada. (CORRAR et al., 2009). O objetivo, nesse caso, é a extração de fatores sob a perspectiva de uma variável no decorrer do tempo. Nesse módulo, as colunas representam as empresas, as linhas correspondem aos anos e as células são a medida de uma única variável. Seguindo o exemplo anterior, corresponde a avaliar apenas a variável ROA (Return On Asset), durante diversos anos em várias empresas, com o objetivo de consolidar fatores comuns no comportamento dessas variáveis durante o período observado. A Figura 5 representa sua estruturação:

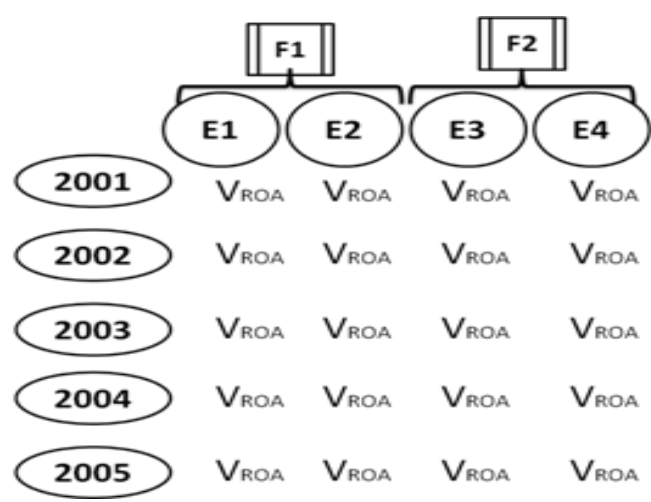

Figura 5: S-mode factor analysis

Fonte: Adaptada de Corrar et al., 2009, p. 85. 
Este trabalho utilizou a análise de variáveis $S$-mode factor analysis, pois pretendeu observar a variabilidade comum para cada um dos betas contábeis indicados como explicativos dos betas de mercado e valor pesquisados.

Para a escolha da quantidade de fatores, optou-se pelo método scree plot que, mediante um gráfico de declive, indica a quantidade de fatores que agregam, individualmente, na análise. Somado a isso, foi realizado o método de rotação varimax para explicar o mesmo grau de variância total. É um tipo de rotação ortogonal e um dos mais utilizados. Esse método tem como característica o fato de minimizar a ocorrência de uma variável possuir altas cargas fatoriais para diferentes fatores, permitindo que uma variável seja facilmente identificada como um único fator.

Este trabalho utilizou-se da Análise Estatística Fatorial, pelo método de Componentes Principais, por meio da análise $S$-mode factor analysis para extrair as variações comuns entre as empresas analisadas no período. O objetivo foi verificar parte da tese, deste trabalho, afirmando ou não se existe uma variabilidade comum, nos betas contábeis e betas de mercado das empresas estudadas.

Para isso foi utilizado o software SPSS (Statistical Package for the Social Sciences). Foram realizados alguns testes nos dados para verificar a adequação da ferramenta de ACP.

1. Primeiramente, foi realizado o teste KMO (Kaiser-Meyer-Olkin) que mede o grau de correlação entre as variáveis. As variáveis só podem ser utilizadas, nessa ferramenta, se possuírem correlação parcial entre elas. Com isso, seu Measure of Sampling Adequancy deve ser maior que 0,50 .

2. O seguinte teste foi o Bartlett's test of sphericity que, na mesma linha do anterior, indica se a matriz de correlação é uma matriz identidade, ou seja, se há correlação zero entre as variáveis. Como resultado, nesse teste, buscou-se nível de significância menor que 0,05.

3. O terceiro passo foi observar a matriz de correlação das variáveis das empresas, que deve mostrar um nível acima de 0,40.

4. Depois disso, foi preciso analisar as Comunalidades entre variáveis das empresas, que mostra o total de correlação entre cada empresa como as demais. Esse número deve ser maior que 0,70 . 
Depois de passados nesses testes de adequação ao método, foram extraídos os fatores comuns entre as variáveis e extraídos seus scores para, na sequência, se realizar a análise por Correlação Canônica.

\subsubsection{Correlação canônica}

O quarto passo do trabalho buscou saber se, para as variáveis que possuíssem componentes principais, esses componentes estão correlacionados, isto é, se os betas contábeis e betas de mercado possuem os mesmos componentes, podendo o beta contábil cooperar na estimação do risco de uma empresa. Com isso, foram utilizadas técnicas de dependência, mais precisamente, foi utilizada a técnica de correlação canônica, que visava à previsão das variáveis dependentes.

Existem várias formas de analisar dois conjuntos de dados. Um dos modelos mais comuns de análise é a regressão múltipla. Na regressão múltipla, uma variável é explicada por uma combinação linear de outras variáveis. A variável a ser explicada é chamada de dependente e as variáveis explicativas são chamadas de independentes. (HAIR et al., 1998; JONSON; WICHERN, 1988) . A equação básica de uma regressão múltipla pode ser expressa por:

$$
Y_{1}=X_{1}+X_{2}+X_{3}+\ldots .+X_{n}
$$

A correlação canônica pode ser vista como uma extensão da regressão múltipla. Na correlação canônica, existem duas ou mais variáveis dependentes. (HAIR et al., 1998; JONSON; WICHERN, 1988). A equação básica pode ser expressa por:

$$
Y_{1}+Y_{2}+Y_{3}+\ldots+Y_{n}=X_{1}+X_{2}+X_{3}+\ldots+X_{n}
$$

O objetivo da correlação canônica é determinar uma combinação linear para cada grupo de variáveis (dependentes e independentes) que maximize a correlação entre os dois grupos. Funções adicionais não correlacionadas com a primeira podem ser calculadas, sendo limitadas pelo número de variáveis do menor grupo. (HAIR et al., 1998; JONSON; WICHERN, 1988). 
Uma forma de expressar uma correlação canônica pode ser: determine uma combinação linear entre x e y, tal que a correlação $\operatorname{Corr}(U, V)$ seja maximizada.

$$
\begin{aligned}
& U=a_{1} x_{1}+a_{2} x_{2}+\ldots+a_{n} x_{n} \\
& V=b_{1} y_{1}+b_{2} y_{2}+\ldots+b_{n} y_{n}
\end{aligned}
$$

Detalhando um pouco mais, suponha X sendo uma matriz nxp e Y nxq. Separar essa matriz C

$$
C=\operatorname{cov}(X, Y)
$$

em quatro partes:

$$
C=\left[\begin{array}{ll}
\sum_{p x p} 11 & \sum_{p x q} 12 \\
\sum_{q x p} 21 & \sum_{q x q} 22
\end{array}\right]
$$

As covariâncias entre variáveis de diferentes conjuntos, uma variável de $\mathrm{X}$ e outra de $\mathrm{Y}$ estarão contidas em (12) ou (21). Analisar as covariâncias em (12) ou (21) pode ser extremamente trabalhoso, ainda mais se $\mathrm{p}$ e q forem grandes. Contudo, o principal objetivo da correlação canônica é resumir as associações entre $\mathrm{X}$ e $\mathrm{Y}$ em função de algumas poucas correlações escolhidas, ao invés das pxq correlações. Combinação linear é uma forma simples

$$
\begin{aligned}
& U=a^{\prime} X \\
& V=b^{\prime} Y
\end{aligned}
$$

de resumir um conjunto de variáveis, então seja:

$$
\begin{aligned}
& \operatorname{Var}(U)=a^{\prime} \operatorname{Cov}(X) a=a^{\prime} \sum_{11} a \\
& \operatorname{Var}(V)=b^{\prime} \operatorname{Cov}(Y) b=b^{\prime} \sum_{22} b \\
& \operatorname{Cov}(U, V)=a^{\prime} \operatorname{Cov}(X, Y) b=a^{\prime} \sum_{12} b
\end{aligned}
$$


O que a correlação canônica procura é determinar os vetores a e b, tais que

$$
\operatorname{Corr}(U, V)=\frac{a^{\prime} \sum_{12} b}{\sqrt{a^{\prime} \sum_{11} a} \sqrt{b^{\prime} \sum_{22} b}}
$$

seja a maior possível. Existirão min(p,q)-1 pares de variáveis canônicas independentes do par de correlação máxima, que expressarão a variância total dos dois grupos de variáveis. Para calcular esse máximo, restrita pela combinação linear (primeiro par de variáveis canônicas):

$$
\begin{gathered}
\max _{a, b} \operatorname{Corr}(U, V)=\rho_{1}^{*} \\
U_{1}=\underbrace{e_{1}^{\prime} \sum_{11}^{-1 / 2} X} \text { e } V_{1}=\underbrace{f_{1}^{\prime} \sum_{22}^{-1 / 2} Y}
\end{gathered}
$$

Supondo 'A' uma matriz quadrada kxk e ' $v$ ' um vetor kx1, pode-se mostrar que a equação

$$
A v=\lambda v
$$

O k-ésimo par de variáveis canônicas pode ser descrito como:

$$
U_{k}=e_{k}^{\prime} \sum_{11}^{-1 / 2} X \quad \text { e } \quad V_{k}=f_{k}^{\prime} \sum_{22}^{-1 / 2} Y
$$

maximizando,

$$
\operatorname{Corr}\left(U_{k}, V_{k}\right)=\rho_{k}^{*}
$$

Para o entendimento conceitual e matemático da Correlação canônica, sugere-se Hair et al. (2005), Multivariate Data Analysis.

Este trabalho utilizou a correlação canônica para verificar se o componente sistêmico de betas contábeis explicam o componente sistêmico dos betas de mercado. Para isso, foi utilizado o software SPSS (Statistical Package for the Social Sciences). Realizam-se alguns testes nos dados para verificar a adequação da ferramenta. Os passos para o cálculo da correlação 
canônica foram: (1) especificação dos objetivos da análise; (2) desenvolvimento do plano de análise; (3) teste das hipóteses da correlação; (4) estimativa do modelo e cálculo do poder de explicação; (5) interpretação dos resultados e (6) validação do modelo.

(1) Especificação dos objetivos da análise: como já demonstrado, o objetivo foi verificar se o componente sistêmico dos lucros são correlacionados e explicam o componente sistêmico do valor da ação.

(2) Desenvolvimento do plano de análise: a amostra foi composta pelos scores da análise de componentes principais.

(3) Premissas: foi testada para cada grupo de variáveis a linearidade da correlação, normalidade, homocedasticidade e multicolinearidade.

(4) Cálculo do modelo: foram calculados os autovetores e autovalores e os outros resultados, como: 'loadings' e 'cross-loadings'.

(5) Interpretação dos resultados: testou-se a significância das relações e de cada um dos índices, como: pesos, 'loadings' e 'cross-loadings'.

Dessa forma, a técnica de correlação canônica é útil em problemas que possuam mais de uma variável métrica dependente. $\mathrm{O}$ uso da correlação canônica pode simplificar o problema e determinar quais variáveis são mais importantes na análise. Assim sendo, pôde-se realizar a análise em quatro etapas: na primeira, encontram-se as variáveis e os betas contábeis com maiores associações com o beta de mercado; na segunda, verificaram-se quais desses possuíam, realmente, poder em explicar o risco sistemático; na terceira, dentre os betas contábeis apontados na análise de dados em painel, determinaram-se os principais componentes comuns das variáveis e na quarta etapa, realizou-se a correlação canônica para medir a relação entre cada dois grupos de fatores. 


\section{ANÁLISE DOS RESULTADOS}

Com o intuito de saber se existe relação entre a informação contábil e o risco sistemático e se a informação contábil pode cooperar para estimar o beta de mercado de uma empresa foram testadas seis hipóteses.

O primeiro passo foi aplicar a ferramenta estatística de Correlação para 6 betas de mercado com relação a 468 variáveis independentes, que correspondem a betas contábeis, média e desvio-padrão de informações contábeis. O segundo passo foi selecionar as variáveis que obtiveram uma maior relação com betas de mercado e analisar se elas podem explicar, antecipar e melhorar a previsão do beta de mercado mediante a análise de dados em painel. $\mathrm{O}$ terceiro passo foi verificar se os betas contábeis, resultantes das análises de dados em painel, e os betas de mercado possuíam componentes comuns. E o quarto passo foi verificar se esses componentes estão relacionados, podendo ser os mesmos, mostrando que o beta contábil pode cooperar para estimar o beta de mercado.

A primeira hipótese metodológica testada foi:

\section{$H_{0,1}$ : Existe associação entre o beta contábil de uma empresa e o beta de mercado de suas ações.}

Para tanto, foram realizadas correlações entre as 36 versões de cada uma das 15 variáveis contábeis selecionadas por este estudo, com relação aos 6 possíveis betas de mercado, totalizando 2.808 coeficientes de correlação analisados. Com a intenção de verificar se existia associação para essa ampla quantidade de variáveis foram testadas 39 sub-hipóteses que observaram se o coeficiente de correlação era significativo, se possuía sinal positivo ou negativo e se representava um valor considerável, aceitando ou rejeitando as sub-hipóteses e a hipótese $\mathbf{H}_{\mathbf{0}, 1}$, de que existe alguma relação entre o beta contábil de uma empresa e o beta de mercado de suas ações, para cada uma das variáveis testadas.

Os betas de mercado foram calculados por meio dos retornos trimestrais ocorridos entre o primeiro trimestre de 1995 e o terceiro trimestre de 2009; seguindo as fórmulas evidenciadas, no capítulo 4, para cada empresa, foram gerados seis betas de mercado para o período. $\mathrm{O}$ 
mesmo ocorreu com os betas contábeis que também foram calculados por intermédio dos dados trimestrais da empresa e da média das empresas da amostra ocorridos entre o primeiro trimestre de 1995 e o terceiro trimestre de 2009, o que levou a um beta contábil da empresa para cada versão da variável. Por fim, para o cálculo da média e do desvio-padrão foram considerados, também, os dados trimestrais entre o primeiro trimestre de 1995 e o terceiro trimestre de 2009, obtendo-se a uma média e um desvio-padrão da empresa, para cada versão da variável estudada.

Conforme outros estudos Ball e Brown (1969), Gonedes (1973), Ilha et al. (2009), Pettit e Westerfield (1972), Rosenberg e Mckibben (1973), Rodrigues et al. (2008) e Teixeira e Valle (2008), o coeficiente de correlação foi considerado como relevante acima de 0,25. Sendo assim, se a relação entre um beta contábil e o beta de mercado é positiva e acima de 0,25 , foi considerado que existe uma associação positiva para essas duas variáveis, aceitando $\mathbf{H}_{\mathbf{0 , 1}}$. Da mesma forma, se a relação entre um beta contábil e o beta de mercado é negativa e acima de 0,25, foi considerado que existe uma associação inversa para as duas as variáveis, também aceitando $\mathbf{H}_{\mathbf{0 , 1}}$. Entretanto, mesmo ao aceitar $\mathbf{H}_{\mathbf{0}, \mathbf{1}}$, uma sub-hipótese pode ser rejeitada. Por exemplo, espera-se que a seguinte sub-hipótese seja verdadeira, " $\mathbf{H}_{\mathbf{0 , 1 - 2}}$ Quanto maior a média da variável de lucro líquido, menor será o beta de mercado". No entanto, para a média da variável de lucro líquido a sub-hipótese foi rejeitada, pois essa obteve coeficientes de correlação positivos ao redor de $29 \%$ e não houve coeficientes negativos em magnitude relevante. Nesse caso, aceita-se $\mathbf{H}_{\mathbf{0 , 1}}$ e rejeita-se $\mathbf{H}_{\mathbf{0 , 1 - 2}}$.

Dessa forma, quando encontrados coeficientes de correlação acima de 0,25 , positivos ou negativos, para uma determinada variável, hipótese $\mathbf{H}_{\mathbf{0 , 1}}$ aceita e as sub-hipóteses foram aceitas ou rejeitadas. Foram rejeitadas a hipótese $\mathbf{H}_{\mathbf{0 , 1}}$ e as sub-hipóteses, quando uma variável não apresentou associação acima de 0,25 para nenhum dos betas de mercado estudados, por não apresentarem coeficiente de correlação de tamanhos significativos. Ainda, nos casos em que foram encontradas correlações positivas e negativas acima de 0,25 para uma mesma variável com os betas de mercado, a hipótese $\mathbf{H}_{\mathbf{0 , 1}}$ foi aceita. Nesse último caso, não foi possível aceitar ou rejeitar as sub-hipóteses, pois os coeficientes apresentaram uma gama de resultados contraditórios.

Os resultados gerados na amostra para a maior parte das versões de betas contábeis foram pouco significativas ou mesmo inexistentes em grande parte das relações analisadas. Entretanto, para uma parte menor das versões de betas contábeis, os resultados da correlação 
apontam que, mesmo apesar dos coeficientes de correlação não serem elevados, ao redor de $30 \%$, não se pode negar que existe, em algum grau, uma associação entre os betas e as variáveis contábeis com os betas de mercado. Com o intuito de não estender esse capítulo e incidi-lo com excesso de tabelas, os resultados dos testes de correlação foram colocados no Anexo 1 desta tese. A seguir, são apresentados os resultados para a hipótese $\mathbf{H}_{\mathbf{0 , 1}}$ e as respostas para cada uma das sub-hipóteses apresentadas no capítulo 4:

\section{$\mathrm{H}_{0,1-1}$ : Quanto maior o beta contábil de lucro líquido, maior será o beta de mercado.}

A hipótese $\mathbf{H}_{\mathbf{0 , 1}}$ foi aceita. A sub-hipótese pode ser aceita para as variáveis beta contábil de LL, LL/AT e LL/VM que tiveram coeficientes de correlação entre $29 \%$ e $36 \%$.

$\mathrm{H}_{\text {0,1-2: }}$ Quanto maior a média de lucro líquido, menor será o beta de mercado.

A hipótese $\mathbf{H}_{0,1}$ foi aceita.Essa sub-hipótese pode ser rejeitada para a variável da média da $1^{\text {a }}$ diferença de LL/AT que tiveram coeficientes de correlação de $29 \%$.

$\mathrm{H}_{\text {0,1-3: }}$ Quanto maior a variabilidade do lucro líquido, maior será o beta de mercado.

A hipótese $\mathbf{H}_{\mathbf{0}, 1}$ foi aceita. A sub-hipótese pode ser aceita para o desvio-padrão de LL e sua $1^{\mathrm{a}}$ diferença que tiveram coeficientes de correlação ao redor de $28 \%$.

$H_{0,1-4}$ : Quanto maior o beta contábil de EBIT, maior será o beta de mercado.

A hipótese $\mathbf{H}_{0,1}$ foi aceita. A sub-hipótese pode ser aceita para o beta contábil de EBIT/VM e EBIT/AT e suas $1^{\text {as }}$ diferenças que tiveram coeficientes de correlação ao redor de $31 \%$.

$H_{0,1-5:}$ Quanto maior a média de EBIT, menor será o beta de mercado.

A hipótese $\mathbf{H}_{0,1}$ foi aceita. A sub-hipótese pode ser rejeitada para o beta contábil de EBIT/VM e EBIT/AT e suas $1^{\text {as }}$ diferenças que tiveram coeficientes de correlação ao redor de $28 \%$.

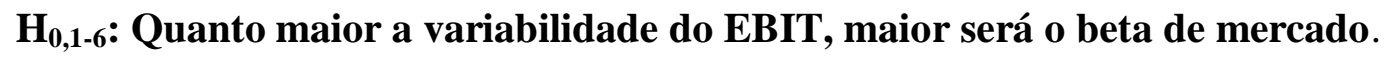

A hipótese $\mathbf{H}_{0,1}$ foi aceita. A sub-hipótese pode ser aceita para a variabilidade do EBIT/VM e sua $1^{\text {a }}$ diferença que tiveram coeficientes de correlação ao redor de $39 \%$.

$\mathrm{H}_{0,1-7}$ : Quanto maior o beta contábil de LAIR, maior será o beta de mercado.

A hipótese $\mathbf{H}_{\mathbf{0 , 1}}$ foi aceita. A sub-hipótese pode ser aceita para o beta contábil de LAIR e LAIR/AT e suas $1^{\text {as }}$ diferenças que tiveram coeficientes de correlação ao redor de $30 \%$. 
$\mathrm{H}_{0,1-8}$ : Quanto maior a média de LAIR, menor será o beta de mercado.

A hipótese $\mathbf{H}_{0,1}$ foi aceita. A sub-hipótese pode ser rejeitada, pois, assim como ocorreu com o Lucro Líquido e o EBIT, quanto maior o LAIR e LAIR/AT e suas $1^{\text {as }}$ diferenças, maior o beta de mercado.

$H_{0,1-9}$ : Quanto maior a variabilidade do LAIR, maior será o beta de mercado.

A hipótese $\mathbf{H}_{0,1}$ foi aceita. A sub-hipótese pode ser aceita para a variabilidade do LAIR e sua $1^{a}$ diferença que tiveram coeficientes de correlação ao redor de $32 \%$.

$\mathrm{H}_{\text {0,1-10: }}$ Quanto maior o beta contábil de LPA, maior será o beta de mercado.

A hipótese $\mathbf{H}_{0,1}$ foi aceita. A sub-hipótese pode ser aceita para o percentual de variação do LPA que teve coeficiente de correlação ao redor de $24 \%$.

$\mathbf{H}_{0,1-11}$ : Quanto maior a média de LPA, menor será o beta de mercado.

A hipótese $\mathbf{H}_{0,1}$ foi rejeitada. A sub-hipótese não pode ser aceita, pois as variáveis não apresentaram coeficientes de correlação de tamanhos significativos.

$\mathrm{H}_{0,1-12}$ : Quanto maior a variabilidade do LPA, maior será o beta de mercado.

A hipótese $\mathbf{H}_{\mathbf{0}, \mathbf{1}}$ foi aceita. A sub-hipótese pode ser aceita para o percentual de variabilidade do LPA, que teve coeficiente de correlação ao redor de $26 \%$.

$H_{0,1-13}$ : Quanto maior o beta contábil de receita, menor será o beta de mercado.

A hipótese $\mathbf{H}_{\mathbf{0}, \mathbf{1}}$ foi aceita. A sub-hipótese pode ser aceita para o beta contábil de Receita/AT e Receita/VM e suas $1^{\text {as }}$ diferenças que tiveram coeficientes de correlação ao redor de $30 \%$.

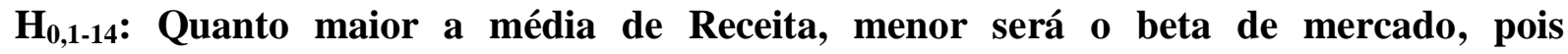
faturamentos maiores e maiores market shares reduzem o risco.

A hipótese $\mathbf{H}_{\mathbf{0 , 1}}$ foi aceita. A sub-hipótese não pode ser aceita ou rejeitada, pois as variáveis apresentaram resultados que se contradizem.

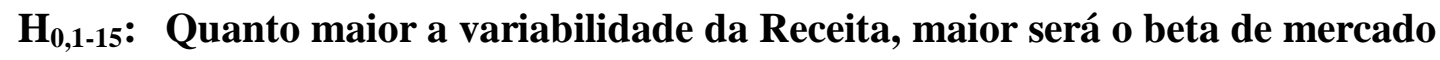
(receitas que oscilam demasiadamente aumentam o risco da empresa) 
A hipótese $\mathbf{H}_{0,1}$ foi aceita. A sub-hipótese pode ser aceita para o beta contábil de Receita/AT e Receita/VM e suas $1^{\text {as }}$ diferenças que tiveram coeficientes de correlação ao redor de $30 \%$.

H,1- 16: Quanto maior a média de Tamanho, menor será o beta de mercado.

A hipótese $\mathbf{H}_{\mathbf{0}, \mathbf{1}}$ foi aceita. A sub-hipótese não pode ser aceita ou rejeitada, pois as variáveis apresentaram resultados que se contradizem.

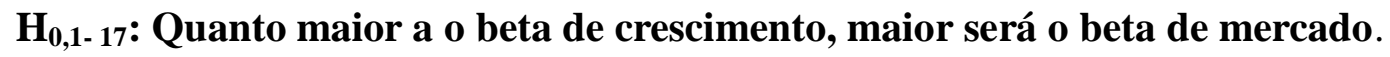

A hipótese $\mathbf{H}_{0,1}$ foi rejeitada. A sub-hipótese não pode ser aceita, pois as variáveis não apresentaram coeficiente de correlação de tamanhos significativos.

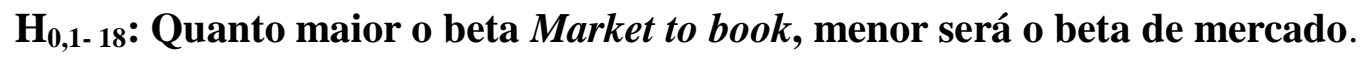

A hipótese $\mathbf{H}_{\mathbf{0}, \mathbf{1}}$ foi aceita. A sub-hipótese não pode ser aceita ou rejeitada, pois as variáveis apresentaram resultados que se contradizem.

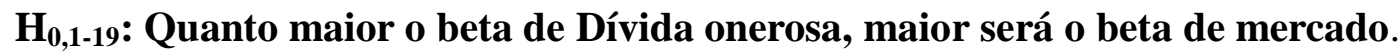

A hipótese $\mathbf{H}_{\mathbf{0 , 1}}$ foi aceita. A sub-hipótese pode ser aceita para o beta contábil de Dívida, Dívida/PL, Dívida/AT e Dívida/VM e suas $1^{\text {as }}$ diferenças que tiveram coeficientes de correlação ao redor de $27 \%$.

$\mathrm{H}_{\text {0,1-20: }}$ Quanto maior a média de Dívida onerosa, maior será o beta de mercado.

A hipótese $\mathbf{H}_{0,1}$ foi aceita. A sub-hipótese pode ser aceita para o beta contábil de Dívida/PL e Dívida/AT e suas $1^{\text {as }}$ diferenças que tiveram coeficientes de correlação ao redor de $26 \%$.

$\mathrm{H}_{\text {0,1-21 }}$ : Quanto maior a variabilidade da Dívida onerosa, maior será o beta de mercado.

A hipótese $\mathbf{H}_{\mathbf{0}, \mathbf{1}}$ foi aceita. A sub-hipótese pode ser aceita para o beta contábil de Dívida, Dívida/PL e Dívida/AT e suas $1^{\text {as }}$ diferenças que tiveram coeficientes de correlação ao redor de $28 \%$.

$\mathrm{H}_{\text {0,1-22: }}$ Quanto maior o beta de Endividamento, maior será o beta de mercado.

A hipótese $\mathbf{H}_{\mathbf{0 , 1}}$ foi aceita. A sub-hipótese pode ser aceita para o beta contábil de Endividamento e sua $1^{\mathrm{a}}$ diferença e Endividamento/AT que apresentaram coeficientes de correlação ao redor de $33 \%$. 
$\mathrm{H}_{0,1-23}$ : Quanto maior a média de Endividamento, maior será o beta de mercado.

A hipótese $\mathbf{H}_{\mathbf{0 , 1}}$ foi aceita. A sub-hipótese pode ser aceita para o beta contábil de Endividamento e Endividamento/AT e suas $1^{\text {as }}$ diferenças que apresentaram coeficientes de correlação ao redor de $32 \%$.

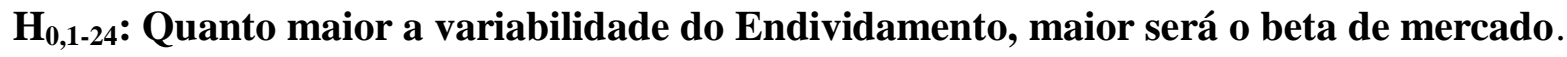 inconclusivo}

A hipótese $\mathbf{H}_{\mathbf{0}, \mathbf{1}}$ foi aceita. A sub-hipótese não pode ser aceita ou rejeitada, pois as variáveis apresentaram resultados que se contradizem.

$\mathrm{H}_{\text {0,1-25: }}$ Quanto maior o beta de Liquidez, menor será o beta de mercado.

A hipótese $\mathbf{H}_{\mathbf{0}, \mathbf{1}}$ foi aceita. A sub-hipótese pode ser rejeitada, pois os coeficientes mostraram que maiores índices de liquidez podem estar associados com maiores betas de mercado.

$\mathrm{H}_{\text {0,1-26: }}$ Quanto maior a média de Liquidez, menor será o beta de mercado.

A hipótese $\mathbf{H}_{\mathbf{0 , 1}}$ foi aceita. A sub-hipótese pode ser rejeitada, pois os coeficientes mostraram que maiores índices de liquidez podem estar associados com maiores betas de mercado.

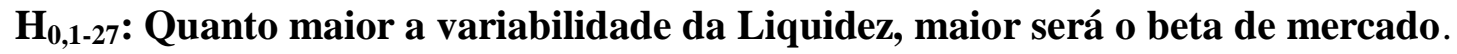

A hipótese $\mathbf{H}_{\mathbf{0 , 1}}$ foi aceita. A sub-hipótese não pode ser aceita ou rejeitada, pois as variáveis apresentaram resultados que se contradizem.

$\mathrm{H}_{\text {0,1-28: }}$ Quanto maior o beta de Capital de Giro, menor será o beta de mercado.

A hipótese $\mathbf{H}_{\mathbf{0 , 1}}$ foi aceita. A sub-hipótese pode ser rejeitada, pois os coeficientes mostraram que betas de Capital de Giro podem estar positivamente associados com maiores betas de mercado. 


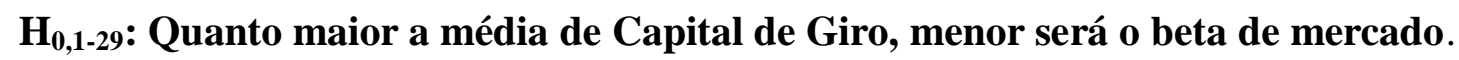

A hipótese $\mathbf{H}_{\mathbf{0 , 1}}$ foi aceita. A sub-hipótese pode ser aceita para o a média do Capital de Giro, Capital de Giro padronizado por PL e AT e suas $1^{\text {as }}$ diferenças que tiveram coeficientes de correlação que chegaram a $40 \%$.

$\mathrm{H}_{\text {0,1-30: }}$ Quanto maior a variabilidade do Capital de Giro, maior será o beta de mercado. A hipótese $\mathbf{H}_{\mathbf{0 , 1}}$ foi aceita. A sub-hipótese não pode ser aceita ou rejeitada, pois as variáveis apresentaram uma gama de resultados que se contradizem.

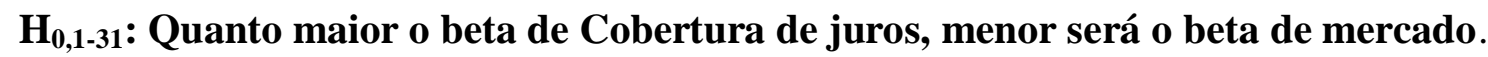

A hipótese $\mathbf{H}_{\mathbf{0 , 1}}$ foi aceita. A sub-hipótese pode ser aceita para o beta de Cobertura de juros que tiveram coeficientes de correlação ao redor de $25 \%$.

$\mathrm{H}_{\text {0,1-32: }}$ Quanto maior a média de Cobertura de juros, menor será o beta de mercado.

A hipótese $\mathbf{H}_{\mathbf{0}, \mathbf{1}}$ foi aceita. A sub-hipótese não pode ser aceita ou rejeitada, pois as variáveis apresentaram uma gama de resultados que se contradizem.

$\mathrm{H}_{\text {0,1-33: }}$ Quanto maior a variabilidade de Cobertura de juros, maior será o beta de mercado.

A hipótese $\mathbf{H}_{\mathbf{0 , 1}}$ foi aceita. A sub-hipótese não pode ser aceita ou rejeitada, pois as variáveis apresentaram uma gama de resultados que se contradizem.

$\mathrm{H}_{\text {0,1-34: }}$ Quanto maior o beta de GAO, maior será o beta de mercado.

A hipótese $\mathbf{H}_{\mathbf{0 , 1}}$ foi aceita. A sub-hipótese não pode ser aceita ou rejeitada, pois as variáveis apresentaram uma gama de resultados que se contradizem.

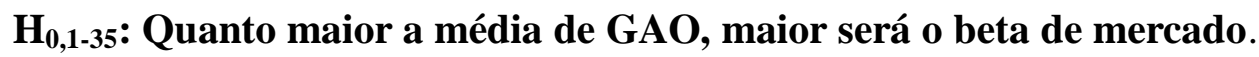

A hipótese $\mathbf{H}_{\mathbf{0 , 1}}$ foi aceita. A sub-hipótese pode ser aceita para a média de GAO e sua $1^{\text {a }}$ diferença que teve coeficientes de correlação ao redor de $25 \%$.

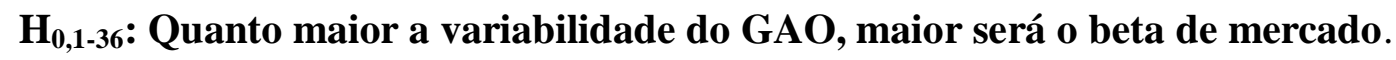

A hipótese $\mathbf{H}_{\mathbf{0 , 1}}$ foi aceita. A sub-hipótese não pode ser aceita ou rejeitada, pois as variáveis apresentaram uma gama de resultados que se contradizem. 
$\mathrm{H}_{\text {0,1-37 }}$ : Quanto maior o beta de GAF, maior será o beta de mercado.

A hipótese $\mathbf{H}_{\mathbf{0}, \mathbf{1}}$ foi aceita. A sub-hipótese pode ser aceita para a média de GAF/AT e sua $1^{\text {a }}$ diferença que teve coeficientes de correlação ao redor de $35 \%$.

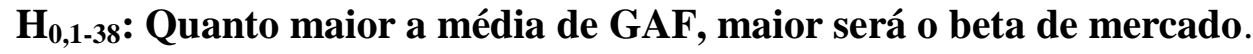

A hipótese $\mathbf{H}_{\mathbf{0 , 1}}$ foi rejeitada. A sub-hipótese não pode ser aceita, pois as variáveis não apresentaram coeficientes de correlação de tamanhos significativos.

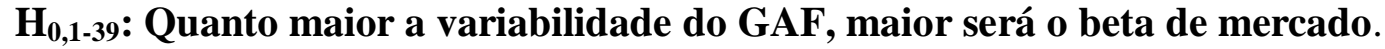

A hipótese $\mathbf{H}_{\mathbf{0 , 1}}$ foi aceita. A sub-hipótese pode ser aceita para a média de GAF e sua $1^{\text {a }}$ diferença que teve coeficientes de correlação ao redor de $34 \%$.

O intuito dessa primeira etapa foi, primeiramente, aceitar ou rejeitar a hipótese metodológica $\mathrm{H}_{0,1}$ : "Existe associação entre o beta contábil de uma empresa e o beta de mercado de suas ações". Observando as correlações, apesar de os coeficientes de correlação não serem elevados, não se pode negar que exista, para determinadas variáveis e betas contábeis uma associação com os betas de mercado. Entretanto para a grande maioria dos betas contábeis calculados não foi encontrada nenhuma associação com os betas de mercado, rejeitando a hipótese $\mathbf{H}_{\mathbf{0 , 1}}$.

O segundo passo foi, então, testar a segunda hipótese metodológica: $\mathbf{H}_{\mathbf{0 , 2}}$ : $\mathbf{O}$ beta contábil de uma empresa pode explicar o beta de mercado de suas ações. Para aceitar ou rejeitar $\mathbf{H}_{0,2}$ foram utilizados os resultados da correlação na seleção de possíveis betas contábeis que poderiam explicar o beta de mercado. Foram selecionadas todas as variáveis (sejam em forma de betas contábeis, médias ou desvio-padrão) que apresentaram coeficientes de correlação acima de $25 \%$, seja ele com sinal positivo ou negativo e que levava a aceitar ou rejeitar as sub-hipóteses. Para as variáveis eleitas na correlação, foi escolhida sua versão beta contábil para aceitar ou rejeitar $\mathbf{H}_{\mathbf{0 , 2}}$. Ficaram de fora as variáveis e betas contábeis que apresentaram resultados contraditórios ou que não apresentaram coeficientes de correlação mínimos de $25 \%$.

Dessa forma, foram selecionados 27 betas contábeis:

\section{Betas de variáveis de rentabilidade}


1. LL? - Beta contábil de Lucro líquido trimestral;

2. LLAT? - Beta contábil de Lucro líquido/Ativo total;

3. LLVM? - Beta contábil de Lucro líquido/Valor de Mercado;

4. EBITAT? - Beta contábil de EBIT/Ativo total;

5. EBITVM? - Beta contábil de EBIT/ Valor de Mercado;

6. LAIR? - Beta contábil de Lucro Antes do Imposto de Renda;

7. LAIRAT? - Beta contábil de Lucro Antes do Imposto de Renda/Ativo Total;

8. CLPA? - Beta contábil do crescimento percentual do indicador Lucro por Ação;

\section{Betas de variáveis operacionais}

9. CMTB? - Beta contábil do crescimento percentual do indicador Market to book;

10. RECAT? - Beta contábil da receita líquida sobre o Ativo Total;

11. RECPL? - Beta contábil da receita líquida sobre o Patrimônio Líquido;

12. RECVM? - Beta contábil da receita líquida sobre o Valor de Mercado;

\section{Betas de variáveis financeiras}

13. DIV? - Beta contábil da Dívida onerosa;

14. DIVAT? - Beta contábil da dívida onerosa sobre o Ativo Total;

15. DIVPL? - Beta contábil da dívida onerosa sobre o Patrimônio Líquido;

16. END? - Beta contábil do total de capital de terceiros (Passivo Circulante + Exigível a longo prazo);

17. ENDAT? - Beta contábil do total de capital de terceiros (Passivo Circulante + Exigível a longo prazo) sobre o Ativo Total;

18. ENDPL? - Beta contábil do total de capital de terceiros (Passivo Circulante + Exigível a longo prazo) sobre o Patrimônio Líquido;

19. COBJUR? - Beta contábil do Grau de Cobertura de Juros, Lucro Líquido sobre as Despesas Financeiras;

20. GAF? - Beta do Grau de Alavancagem Financeira;

21. GAO? - Beta do Grau de Alavancagem Operacional;

22. GAOAT? - Beta do Grau de Alavancagem Operacional sobre o Ativo Total;

23. GIRO? - Beta contábil do Capital de Giro;

24. CGIRO? - Beta contábil do crescimento percentual do Capital de Giro;

25. GIROAT? - Beta contábil do Capital de Giro sobre Ativo Total;

26. GIROPL? - Beta contábil do Capital de Giro sobre o Patrimônio Líquido; 
27. LIQ? - Beta contábil do indicador financeiro de Liquidez.

Foi realizada uma análise Dados em Painel com efeitos fixos utilizando betas contábeis e de mercado calculados com base de 4 trimestres, entre o primeiro trimestre de 1995 e o terceiro trimestre de 2009. Para a escolha do modelo de dados em painel a ser utilizado foram realizados os teste de Chow e Hausmann. Ambos apontaram o efeito fixo como o mais adequado a este conjunto de variáveis. Os resultados destes testes estão expostos no Anexo 1. Foram gerados 56 trimestres de betas contábeis diferentes para uma mesma variável. Feito isso, o próximo passo foi selecionar as variáveis e aplicar a seguinte equação:

$$
Y_{i t}=\alpha+\beta X_{i t}+C_{i t}+U_{i t}
$$

em que: $Y_{i t}$ é a informação da evolução temporal da variável dependente para todos os indivíduos da amostra; $X_{i t}$ é a informação da evolução temporal das variáveis independentes para todos os indivíduos da amostra; $C_{i t}$ efeito fixo no tempo e específico do indivíduo, ou seja, o modelo terá a presença de " $n$ " efeitos fixos (um para cada indivíduo da amostra) e $U_{i t}$ o erro aleatório do modelo. Assim, a equação para verificar a hipótese $\mathbf{H}_{\mathbf{0 , 2}}$ :

$$
\begin{aligned}
& \beta_{\text {mercado } i t}=C+U_{i t}+\beta L L_{i t}+C L L_{i t}+\beta \frac{L L}{A T}_{i t}+C \frac{L L}{A T}_{i t}+\beta \frac{L L}{V M}_{i t}+C \frac{L L}{V M}_{i t}+ \\
& \beta \frac{E B I T}{A T}_{i t}+C \frac{E B I T}{A T}_{i t}+\beta \frac{E B I T}{V M}_{i t}+C \frac{E B I T}{V M}_{i t}+\beta \text { Lair }_{i t}+C \text { Lair }_{i t}+\beta \frac{L a i r}{A T}_{i t}+C \frac{\text { Lair }}{A T}_{i t}+ \\
& \beta C L P A_{i t}+C C L P A_{i t}+\beta C M B T_{i t}+C C M B T_{i t}+\beta \frac{R E C}{A T}_{i t}+C \frac{R E C}{A T}_{i t}+\beta \frac{R E C}{P L}_{i t}+C \frac{R E C}{P L}_{i t}+ \\
& \beta L \frac{R E C}{V M}_{i t}+C \frac{R E C}{V M}_{i t}+\beta D I V_{i t}+C D_{i t}+\beta \frac{D I V}{A T} i t_{i t}+C \frac{D I V}{A T} i t_{i t}+\beta \frac{D I V}{P L}_{i t}+C \frac{D I V}{P L}_{i t}+ \\
& \beta E N D_{i t}+C E N D_{i t}+\beta \frac{E N D}{A T}_{i t}+C \frac{E N D}{A T}_{i t}+\beta \frac{E N D}{P L}_{i t}+C \frac{E N D}{P L}_{i t}+\beta C O B J U R_{i t}+ \\
& C \operatorname{COBJUR}_{i t}+\beta G A F_{i t}+C G A F_{i t}+\beta G A O_{i t}+C G A O_{i t}+\beta \frac{G A O}{A T}_{i t}+C \frac{G A O}{A T}_{i t}+ \\
& \beta G I R O_{i t}+C \operatorname{GIRO}_{i t}+\beta C G I R O_{i t}+C \operatorname{CGIRO}_{i t}+\beta \frac{G I R O}{A T}_{i t}+C \frac{G I R O}{A T}_{i t}+\beta \frac{G I R O}{P L}_{i t}+ \\
& C \frac{G I R O}{P L}_{i t}+\beta L I Q_{i t}+C \operatorname{LIQ}_{i t}
\end{aligned}
$$

O resultado, no período entre o quarto trimestre de 1995 e o terceiro trimestre de 2009, mostrou que a equação do conjunto de betas contábeis é significativa estatisticamente $\left(\mathrm{F}_{\text {value }}\right.$ $0,000000)$ e explicam $6 \%$ do beta de mercado $\left(\mathrm{R}^{2}\right.$ de 0,0619$)$, o que pode ser considerado um poder de explicação baixo. Dentre as variáveis foram significativas estatisticamente o Beta contábil de Lucro Líquido, o Beta contábil de EBIT/Ativo Total, o Beta contábil do 
crescimento percentual do indicador Lucro por Ação, o Beta contábil do crescimento percentual do indicador Market to book, Beta contábil do total de capital de terceiros (Passivo Circulante + Exigível a longo prazo) sobre o Patrimônio Líquido e o Beta contábil do Grau de Cobertura de Juros. Os dados podem ser observados na Tabela 4.

Tabela 4 - Betas contábeis x betas de mercado: 15 anos

\begin{tabular}{|c|c|c|c|c|c|c|c|c|}
\hline \multirow{2}{*}{\multicolumn{2}{|c|}{$\begin{array}{l}\text { Dependent Variable: BMT? } \\
\text { Method: Pooled Least Squares }\end{array}$}} & & & & \multicolumn{4}{|c|}{ Fixed Effects (Cross) } \\
\hline & & & & & ACOSVILL--C & 0.136429 & _ITAUSA--C & -0.234432 \\
\hline Sample: 156 & & & & & _ALFACONSORC--C & -0.510565 & _ITAUTEC--C & 0.368916 \\
\hline \multicolumn{2}{|c|}{ Included observations: 56} & & & & _ALFAHOLDING--C & -0.585150 & _KARSTEN--C & -0.290574 \\
\hline \multicolumn{2}{|c|}{ Cross-sections included: 97} & & & & _ALPARGATAS--C & -0.196132 & _KEPLERWEBER--C & -0.307659 \\
\hline \multicolumn{3}{|c|}{ Total pool (balanced) observations: 5432} & & & AMBEV--C & -0.299164 & _KLABINSA--C & 0.194581 \\
\hline & & & & & AMPLAENERG--C & 0.203771 & _LIGHTSA--C & 0.179282 \\
\hline \multirow[t]{2}{*}{ Variable } & Coefficient & Std. Error & t-Statistic & Prob. & AZEVEDO--C & -0.147460 & _LIXDACUNHA--C & 0.334005 \\
\hline & & & & & BAHEMA--C & 0.475714 & _LOJASAMERIC--C & 0.403041 \\
\hline C & 0.723102 & 0.025593 & 2,825402 & 0.0000 & _BARDELLA--C & 0.244693 & _LOJASRENNER--C & -0.991847 \\
\hline CGIRO? & 0.001055 & 0.002803 & 0.376510 & 0.7066 & _BOMBRIL--C & 0.306458 & _MARCOPOLO--C & 0.010053 \\
\hline CLPA? & 0.007183 & 0.003033 & 2,368364 & 0.0179 & _BOTUCATUTEX--C & -0.608095 & _MARISOL--C & -0.235108 \\
\hline СMTB? & 0.014688 & 0.003683 & 3,988485 & 0.0001 & _BRASILTELEC--C & -0.089942 & _METALLEVE--C & 0.019123 \\
\hline COBJUR? & -0.001931 & 0.003253 & -0.593720 & 0.5527 & _BRASKEM--C & 0.503788 & _METISA--C & -0.493457 \\
\hline DIV? & 0.002811 & 0.002764 & 1,016945 & 0.3092 & _BRASMOTOR--C & 0.308200 & _MGPOLIEST--C & 0.609220 \\
\hline DIVAT? & 0.001898 & 0.003599 & 0.527414 & 0.5979 & _BRFFOODS--C & -0.519707 & _MILLENNIUM--C & -0.398845 \\
\hline DIVPL? & 0.010063 & 0.005983 & 1,681818 & 0.0927 & _BUETTNER--C & -0.448318 & _MINUPAR--C & -0.517447 \\
\hline EBITAT? & 0.006717 & 0.004320 & 1,555083 & 0.1200 & _CACIQUE--C & -0.334325 & _MONTARANHA--C & 0.008409 \\
\hline EBITVM? & 0.016261 & 0.005993 & 2,713293 & 0.0067 & _CAMBUCl--C & -0.006290 & _MUNDIAL--C & 0.052942 \\
\hline END? & 0.001927 & 0.007827 & 0.246220 & 0.8055 & _CEB--C & 0.462044 & _PACUCAR--C & 0.194753 \\
\hline ENDAT? & 0.005225 & 0.004916 & 1,062792 & 0.2879 & _CELESC--C & 0.304290 & _PARANAPANEMA-- & -0.261075 \\
\hline ENDPL? & -0.020769 & 0.006858 & $-3,028336$ & 0.0025 & _CEMIG--C & 0.021795 & _PETROBRAS--C & 0.424387 \\
\hline GAF? & -0.001135 & 0.002165 & -0.524321 & 0.6001 & _CESP--C & -0.814917 & _PETROPAR--C & -0.817139 \\
\hline GAO? & -0.005159 & 0.002558 & - 2,016672 & 0.0438 & _CIAHERING--C & 1.274 .604 & _PETTENATI--C & -0.079005 \\
\hline GAOAT? & -0.000603 & 0.002455 & -0.245674 & 0.8059 & _COELCE--C & -0.460063 & _PLASCARPART--C & -0.248951 \\
\hline GIRO? & 0.006661 & 0.006610 & 1,007756 & 0.3136 & _CONFAB--C & 0.032297 & _PROMETALURG--C & 0.103005 \\
\hline GIROAT? & -0.011728 & 0.007181 & $-1,633214$ & 0.1025 & _COPEL--C & 0.722228 & _RANDONPART--C & 0.576510 \\
\hline GIROPL? & 0.000832 & 0.003574 & 0.232814 & 0.8159 & _COTEMINAS--C & -0.184636 & _RECRUSUL--C & -0.067154 \\
\hline LAIR? & 0.002897 & 0.002823 & 1,026553 & 0.3047 & _DHB--C & -0.920834 & _SANSUY--C & 0.295519 \\
\hline LAIRAT? & -0.006060 & 0.005609 & $-1,080537$ & 0.2800 & _DIXIETOGA--C & 0.040687 & _SARAIVALIVR--C & -0.118854 \\
\hline LIQ? & -0.003519 & 0.007576 & -0.464490 & 0.6423 & _DOCAS--C & 0.596902 & _SCHLOSSER--C & 0.492750 \\
\hline LL? & -0.009069 & 0.003186 & - 2,846810 & 0.0044 & _DOHLER--C & 0.152937 & _SCHULZ--C & -0.360917 \\
\hline LLAT? & -0.002391 & 0.003717 & -0.643315 & 0.5200 & _ELEKEIROZ--C & 0.059400 & _SIDNACIONAL--C & 0.424753 \\
\hline LLVM? & 0.014426 & 0.009874 & 1,461067 & 0.1441 & _ELETROBRAS--C & 0.358989 & _SOUZACRUZ--C & -0.147070 \\
\hline RECAT? & 0.013495 & 0.015662 & 0.861631 & 0.3889 & _ELUMA--C & -0.011678 & _SULTEPA--C & -0.935449 \\
\hline RECPL? & -0.001128 & 0.007477 & -0.150921 & 0.8800 & _EMBRAER--C & 0.169976 & _SUZANOPAPEL--C & 0.112871 \\
\hline RECVM? & -0.008761 & 0.013881 & -0.631199 & 0.5279 & _FABCRENAUX--C & -0.315254 & _TECTOY--C & -0.351505 \\
\hline & & & & & _FERBASA--C & 0.206445 & _TELEMARNL--C & -0.457009 \\
\hline & Effects Sp & ecification & & & _FORJASTAURUS--C & 0.207252 & _TELESP--C & 0.100521 \\
\hline Cross & section fixed & (dummy var & riables) & & _FOSFERTIL--C & 0.031350 & _TEXRENAUX--C & -0.082415 \\
\hline R-squared & 0.083165 & Mean depe & endent var & 0.748605 & _FRASLE--C & -0.413040 & _TREVISA--C & -0.273159 \\
\hline Adjusted R-squared & 0.061920 & S.D. depen & dent var & 1,47706 & _GERDAU--C & 0.668819 & _TUPY--C & 0.382599 \\
\hline S.E. of regression & 1.430 .596 & Akaike info & o criterion & 3,57662 & _GERDAUMET--C & 0.507345 & _UNIPAR--C & 0.431208 \\
\hline Sum squared resid & 10863.38 & Schwarz cri & iterion & 3,72729 & _GRAZZIOTIN--C & -0.146546 & _USIMINAS--C & 0.818371 \\
\hline Log likelihood & -9.590 .106 & F-statistic & & 3,91451 & _HERCULES--C & -0.550701 & _VALE--C & -0.014810 \\
\hline Durbin-Watson stat & 0.863956 & Prob(F-stat & tistic) & 0.000000 & _IGBSA--C & 0.142726 & _WEG--C & -0.412426 \\
\hline & & & & & _IGUACUCAFE--C & -0.400690 & _WETZELSA--C & 0.253963 \\
\hline & & & & & _INDSROMI--C & -0.005014 & _WHIRLPOOL--C & 0.400058 \\
\hline & & & & & _INEPAR--C & 0.610811 & _YARABRASIL--C & 0.284620 \\
\hline & & & & & _IOCHPMAXION--C & -0.160583 & & \\
\hline
\end{tabular}

Como o primeiro teste de $\mathbf{H}_{\mathbf{0}, 2}$ observou os betas contábeis no período de 15 anos, os cálculos foram refeitos para um período menor de 5 anos. Os resultados, no período entre o quarto 
trimestre de 2004 e o terceiro trimestre de 2009, mostraram que a equação do conjunto de betas contábeis é significativa estatisticamente $\left(\mathrm{F}_{\text {value }} 0,000000\right)$ e explicam até $27 \%$ do beta de mercado ( $\mathrm{R}^{2}$ de 0,2777$)$, o que pode ser considerado um poder de explicação já considerável. Dentre as variáveis, foram significativas, estatisticamente, o Beta contábil do crescimento percentual do indicador Market to book, o Beta contábil do total de capital de terceiros (Passivo Circulante + Exigível a longo prazo) sobre o Patrimônio Líquido, o Beta contábil da dívida onerosa sobre o Ativo Total, o Beta do Grau de Alavancagem Operacional, o Beta do Grau de Alavancagem Financeira, o Beta contábil de Lucro Antes do Imposto de Renda/Ativo Total, Beta contábil da receita líquida sobre o Ativo Total, o beta contábil do Capital de Giro sobre o PL e o Beta contábil do indicador financeiro de Liquidez. Os dados podem ser observados na Tabela 5 , a seguir.

Tabela 5 - Betas contábeis $x$ betas de mercado: 5 anos 


\begin{tabular}{|c|c|c|c|c|c|c|c|c|}
\hline \multirow{2}{*}{\multicolumn{2}{|c|}{$\begin{array}{l}\text { Dependent Variable: BMT? } \\
\text { Method: Pooled Least Squares }\end{array}$}} & & & & \multicolumn{4}{|c|}{ Fixed Effects (Cross) } \\
\hline & & & & & ACOSVILL--C & 0.281851 & _ITAUSA--C & -0.346899 \\
\hline & & & & & ALFACONSORC--C & -0.942921 & _ITAUTEC--C & 0.092184 \\
\hline Sample: 3656 & & & & & ALFAHOLDING--C & -0.929327 & _KARSTEN--C & -0.301651 \\
\hline \multicolumn{2}{|c|}{ Cross-sections included: 97} & & & & AMBEV--C & -0.595079 & KLABINSA--C & -0.088957 \\
\hline \multicolumn{3}{|c|}{ Total pool (balanced) observations: 2037} & & & AMPLAENERG--C & 0.472131 & _LIGHTSA--C & -0.328989 \\
\hline & & & & & AZEVEDO--C & -0.037557 & _LIXDACUNHA--C & 0.224173 \\
\hline \multirow[t]{2}{*}{ Variable } & Coefficient & Std. Error & t-Statistic & Prob. & BAHEMA--C & -0.159170 & _LOJASAMERIC--C & -0.120576 \\
\hline & & & & & BARDELLA--C & 0.054572 & _LOJASRENNER--C & -1.328 .141 \\
\hline C & 0.715481 & 0.075419 & 9,486751 & 0.0000 & BOMBRIL--C & -0.011167 & _MARCOPOLO--C & -0.206119 \\
\hline CGIRO? & -0.005767 & 0.003426 & $-1,683236$ & 0.0925 & _BOTUCATUTEX--C & 0.792429 & _MARISOL--C & -0.533347 \\
\hline CLPA? & -0.001333 & 0.003658 & -0.364436 & 0.7156 & BRASILTELEC--C & -0.261855 & _METALLEVE--C & -0.147223 \\
\hline CMTB? & 0.165697 & 0.009234 & 1,794355 & 0.0000 & BRASKEM--C & 0.327128 & _METISA--C & -0.140218 \\
\hline COBJUR? & -0.001613 & 0.003535 & -0.456165 & 0.6483 & BRASMOTOR--C & 0.352557 & _MGPOLIEST--C & 0.255417 \\
\hline DIV? & 0.000579 & 0.004123 & 0.140538 & 0.8882 & BRFFOODS--C & 0.120203 & _MILLENNIUM--C & 0.182615 \\
\hline DIVAT? & 0.013223 & 0.005385 & 2,455740 & 0.0141 & _BUETTNER--C & -0.626184 & _MINUPAR--C & -0.751225 \\
\hline DIVPL? & 0.007032 & 0.006331 & 1,110742 & 0.2668 & CACIQUE--C & -0.028406 & _MONTARANHA--C & -8.867 .376 \\
\hline EBITAT? & -0.002951 & 0.006102 & -0.483579 & 0.6287 & _CAMBUCI--C & -0.317343 & _MUNDIAL--C & -0.169863 \\
\hline EBITVM? & -0.000808 & 0.008785 & -0.092006 & 0.9267 & CEB--C & 0.073367 & _PACUCAR--C & 0.113429 \\
\hline END? & 0.005917 & 0.007679 & 0.770503 & 0.4411 & _CELESC--C & -0.053329 & _PARANAPANEMA--C & 0.749438 \\
\hline ENDAT? & 0.003452 & 0.004609 & 0.749061 & 0.4539 & _CEMIG--C & -0.345061 & _PETROBRAS--C & -0.468931 \\
\hline ENDPL? & -0.026893 & 0.007571 & $-3,552177$ & 0.0004 & CESP--C & -1.141 .323 & _PETROPAR--C & -0.432399 \\
\hline GAF? & 0.009936 & 0.004802 & 2,069088 & 0.0387 & _CIAHERING--C & -0.114635 & _PETTENATI--C & -0.097496 \\
\hline GAO? & -0.006368 & 0.002571 & $-2,476813$ & 0.0133 & COELCE--C & -0.265521 & _PLASCARPART--C & 0.531635 \\
\hline GAOAT? & 0.001868 & 0.005993 & 0.311765 & 0.7553 & CONFAB--C & 0.120849 & _PROMETALURG--C & 4.823 .901 \\
\hline GIRO? & 0.014340 & 0.009296 & 1,542585 & 0.1231 & _COPEL--C & -0.218549 & _RANDONPART--C & 0.439957 \\
\hline GIROAT? & -0.017472 & 0.013221 & $-1,321549$ & 0.1865 & _COTEMINAS--C & -0.108638 & _RECRUSUL--C & -0.715178 \\
\hline GIROPL? & -0.015165 & 0.004154 & $-3,650583$ & 0.0003 & DHB--C & -0.322968 & _SANSUY--C & 0.152573 \\
\hline LAIR? & 0.004136 & 0.002992 & 1,382401 & 0.1670 & _DIXIETOGA--C & 0.313686 & _SARAIVALIVR--C & 0.485159 \\
\hline LAIRAT? & -0.070751 & 0.026123 & $-2,708379$ & 0.0068 & DOCAS--C & 0.067876 & _SCHLOSSER--C & 0.167114 \\
\hline LIQ? & 0.134286 & 0.056716 & 2,367677 & 0.0180 & _DOHLER--C & -0.861165 & _SCHULZ--C & -0.236569 \\
\hline LL? & 0.002810 & 0.008355 & 0.336373 & 0.7366 & _ELEKEIROZ--C & 0.315620 & _SIDNACIONAL--C & 0.248041 \\
\hline LLAT? & 0.001324 & 0.003860 & 0.342979 & 0.7317 & _ELETROBRAS--C & -0.027955 & _SOUZACRUZ--C & -0.351676 \\
\hline LLVM? & -0.066256 & 0.044909 & $-1,475338$ & 0.1403 & ELUMA--C & -0.032013 & _SULTEPA--C & 8.678 .619 \\
\hline RECAT? & -0.049618 & 0.026238 & $-1,891085$ & 0.0588 & EMBRAER--C & -0.640465 & _SUZANOPAPEL--C & 0.188746 \\
\hline RECPL? & -0.023682 & 0.012237 & $-1,935309$ & 0.0531 & _FABCRENAUX--C & -0.270175 & _TECTOY--C & -0.391277 \\
\hline \multirow[t]{2}{*}{ RECVM? } & -0.028819 & 0.030906 & -0.932466 & 0.3512 & _FERBASA--C & 0.219638 & _TELEMARNL--C & -0.596720 \\
\hline & & & & & _FORJASTAURUS--C & 0.442777 & _TELESP--C & -0.294637 \\
\hline \multicolumn{2}{|c|}{ Effects Specification } & & & & _FOSFERTIL--C & -0.073544 & _TEXRENAUX--C & 0.459490 \\
\hline & & & & & _FRASLE--C & -0.366870 & _TREVISA--C & -0.650391 \\
\hline \multicolumn{3}{|c|}{ Cross-section fixed (dummy variables) } & & & _GERDAU--C & 0.252693 & _TUPY--C & -0.230789 \\
\hline & & & & & _GERDAUMET--C & 0.328527 & _UNIPAR--C & 0.269468 \\
\hline R-squared & 0.321377 & \multicolumn{2}{|c|}{ Mean dependent vé } & 0.750799 & _GRAZZIOTIN--C & 0.348697 & _USIMINAS--C & 0.585088 \\
\hline Adjusted R-squared & 0.277743 & \multicolumn{2}{|c|}{ S.D. dependent var } & 1,13907 & _HERCULES--C & 0.632789 & _VALE--C & -0.080251 \\
\hline S.E. of regression & 0.968048 & \multicolumn{2}{|c|}{ Akaike info criterioı } & 2,83187 & IGBSA--C & 1.236 .040 & _WEG--C & -0.315693 \\
\hline Sum squared resid & 1,792706 & \multicolumn{2}{|c|}{ Schwarz criterion } & 3,17394 & _IGUACUCAFE--C & -0.521245 & _WETZELSA--C & 0.205336 \\
\hline Log likelihood & $-2,760262$ & \multicolumn{2}{|c|}{ F-statistic } & 7,36538 & _INDSROMI--C & -0.039540 & _WHIRLPOOL--C & 0.455711 \\
\hline \multirow[t]{2}{*}{ Durbin-Watson stat } & 1,142137 & \multicolumn{2}{|c|}{ Prob(F-statistic) } & 0.000000 & _INEPAR--C & 0.898855 & _YARABRASIL--C & 0.294218 \\
\hline & & & & & _IOCHPMAXION--C & 0.381166 & & \\
\hline
\end{tabular}

Feito isto foram selecionados, utilizando o método step wise, apenas os betas contábeis que possuíam significância estatística e testados em painel. Também foi testado a normalidade e a heterocedasticidade dos resíduos. Os resíduos apresentaram tendência a normalidade e heterocedasticidade. Com isso, o painel foi trabalhando utilizando a técnica de correção de erros White, o que transformou os resíduos em homocedásticos. O resultado mostrou poder de explicação para o o Beta da variação percentual do Market to Book, Beta contábil do total de capital de terceiros (Passivo Circulante + Exigível a longo prazo) sobre o Patrimônio Líquido, o Beta do Grau de Alavancagem Operacional, o Beta do Grau de Alavancagem Financeira, o Beta contábil de Lucro Antes do Imposto de Renda/Ativo Total e o Beta contábil do indicador financeiro de Liquidez. Os dados podem ser observados na Tabela 5, a seguir. 
Tabela 6 - Betas contábeis x betas de mercado (Stepwise): 5 anos

\begin{tabular}{|c|c|c|c|c|c|c|c|c|c|}
\hline \multirow{2}{*}{\multicolumn{2}{|c|}{$\begin{array}{l}\text { Dependent Variable: BMT? } \\
\text { Method: Pooled Least Squares }\end{array}$}} & & & & \multicolumn{3}{|c|}{ Cross-section fixed (dummy variables) } & Fixed Effects (Cross) & \multirow[b]{2}{*}{-0.618655} \\
\hline & & & & & _ACOSVILL--C & 0.391600 & _ELETROBRAS--C & 0.212948 _MINUPAR--C & \\
\hline & & & & & _ALFACONSORC- & -0.820607 & ELUMA--C & 0.081812 _MONTARANH & -9.502 .146 \\
\hline Sample: 3656 & & & & & _ALFAHOLDING-- & -0.866875 & EMBRAER--C & -0.535705 _MUNDIAL--C & -0.076533 \\
\hline \multicolumn{2}{|c|}{ Included observations: 21} & & & & _ALPARGATAS--C & -0.042602 & FABCRENAUX--1 & -0.275698 _PACUCAR--C & 0.235286 \\
\hline \multicolumn{2}{|c|}{ Cross-sections included: 97} & & & & _AMBEV--C & -0.490353 & FERBASA--C & 0.252428 _PARANAPANE & 0.882259 \\
\hline \multirow{2}{*}{\multicolumn{5}{|c|}{$\begin{array}{l}\text { Total pool (balanced) observations: } 2037 \\
\text { White cross-section standard errors \& covariance (d.f. corrected) }\end{array}$}} & _AMPLAENERG-- & 0.588385 & _FORJASTAURUS & 0.569152 _PETROBRAS--1 & -0.124920 \\
\hline & & \multicolumn{3}{|c|}{ White cross-section standard errors \& covariance (d.f. corrected) } & _AZEVEDO--C & 0.069509 & FOSFERTIL--C & 0.039543 _PETROPAR--C & -0.336079 \\
\hline & & & & & _BAHEMA--C & -0.094259 & FRASLE--C & -0.272645 _PETTENATI--C & 0.012127 \\
\hline \multirow[t]{2}{*}{ Variable } & Coefficient & Std. Error & t-Statistic & Prob. & _BARDELLA--C & 0.179930 & _GERDAU--C & 0.412721 _PLASCARPAR 7 & 0.654844 \\
\hline & & & & & _BOMBRIL--C & 0.100584 & _GERDAUMET--C & 0.480363 _PROMETALUR & 4.525 .139 \\
\hline C & 0.602285 & 0.040171 & 1,499309 & 0.0000 & _BOTUCATUTEX-- & 0.802848 & _GRAZZIOTIN--C & 0.558451 RANDONPAR & 0.561444 \\
\hline CMTB? & 0.153876 & 0.035352 & 4,352647 & 0.0000 & _BRASILTELEC--C & -0.151764 & HERCULES--C & $-0.114260 \_$RECRUSUL--C & -0.696767 \\
\hline ENDPL? & -0.024337 & 0.006241 & $-3,899700$ & 0.0001 & _BRASKEM--C & 0.449335 & _IGBSA--C & 1.349.371_SANSUY--C & 0.278930 \\
\hline GAF? & 0.008922 & 0.002520 & 3,540837 & 0.0004 & _BRASMOTOR--C & 0.452615 & _IGUACUCAFE--C & -0.454936 _SARAIVALIVR. & 0.725895 \\
\hline GAO? & -0.007085 & 0.002136 & $-3,316422$ & 0.0009 & _BRFFOODS--C & 0.237257 & INDSROMI--C & 0.083500 _SCHLOSSER--C & 0.259267 \\
\hline LAIRAT? & -0.078770 & 0.014410 & $-5,466418$ & 0.0000 & _BUETTNER--C & -0.617276 & IINEPAR--C & 0.459758 _SCHULZ--C & -0.111645 \\
\hline \multirow[t]{2}{*}{ LIQ? } & 0.145631 & 0.040404 & 3,604362 & 0.0003 & _CACIQUE--C & 0.092075 & _IOCHPMAXION- & 0.209240 _SIDNACIONAI & 0.375577 \\
\hline & & & & & _CAMBUCl--C & -0.205160 & _ITAUSA--C & -0.039677_SOUZACRUZ-- & -0.233534 \\
\hline \multicolumn{2}{|c|}{ Effects Specification } & & & & _CEB--C & 0.176158 & _ITAUTEC--C & 0.206353 _SULTEPA--C & 1.509 .176 \\
\hline & & & & & _CELESC--C & 0.051721 & _KARSTEN--C & -0.185002 SSUZANOPAPE & 0.308478 \\
\hline & & & & & _CEMIG--C & -0.241158 & _KEPLERWEBER-- & 0.119092 _TECTOY--C & -0.540822 \\
\hline & & & & & _CESP--C & $-1.005 .503,00$ & -KLABINSA--C & 0.028837 _TELEMARNL--1 & -0.468111 \\
\hline R-squared & 0.308324 & \multicolumn{3}{|c|}{ Mean dependent var 0.750799} & _CIAHERING--C & 0.086393 & _LIGHTSA--C & -0.215692 _TELESP--C & -0.263533 \\
\hline Adjusted R-squared & 0.271845 & \multicolumn{2}{|c|}{ S.D. dependent var } & 1,139072 & _COELCE--C & -0.153535 & _LIXDACUNHA--C & 0.334514 _TEXRENAUX-- & 0.071266 \\
\hline S.E. of regression & 0.971993 & \multicolumn{2}{|c|}{ Akaike info criterion } & 2,830305 & _CONFAB--C & 0.228617 & _LOJASAMERIC-- & 0.009574 _TREVISA--C & -0.615055 \\
\hline Sum squared resid & $1.827 .186,00$ & \multicolumn{2}{|c|}{ Schwarz criterion } & 3,114439 & _COPEL--C & -0.098592 & _LOJASRENNER-- & -1.342.612_TUPY--C & -0.115815 \\
\hline Log likelihood & $2.779 .666,00$ & \multicolumn{2}{|c|}{ Hannan-Quinn criter. } & 2,934536 & _COTEMINAS--C & -0.014554 & _MARCOPOLO--C & -0.081154 _UNIPAR--C & 0.421267 \\
\hline F-statistic & $8.452 .036,00$ & \multicolumn{2}{|c|}{ Durbin-Watson stat } & 1,114372 & -DHB--C & -0.253778 & _MARISOL--C & -0.422012_USIMINAS--C & 0.741196 \\
\hline \multirow[t]{5}{*}{ Prob(F-statistic) } & 0.000000 & & & & _DIXIETOGA--C & 0.435796 & METALLEVE--C & -0.043026 _VALE--C & 0.276398 \\
\hline & & & & & _DOCAS--C & 0.239589 & _METISA--C & -0.266845 _WEG--C & -0.205910 \\
\hline & & & & & _DOHLER--C & -0.825661 & _MGPOLIEST--C & 0.357624 _WETZELSA--C & 0.332311 \\
\hline & & & & & _ELEKEIROZ--C & 0.447526 & _MILLENNIUM--C & 0.217336 _WHIRLPOOL-- & 0.588807 \\
\hline & & & & & & & & _YARABRASIL-- & 0.268241 \\
\hline
\end{tabular}

Por causa do Durbin-Watson baixo $(1,1143)$ foi levantado o indicativo de que os resíduos possuíam auto-correlação. Devido as séries possuírem raiz unitária na primeira diferença suspeitou-se a existência de co-integração entre elas. A co-integração permite determinar se as variáveis possuem ou não um relacionamento (equilíbrio) de longo prazo. Os testes de Engle - Granger constataram que as séries estão co-integradas, possuindo um relacionamento de longo prazo entre 6 betas contábeis e o beta de mercado. Os testes estão apresentados no Anexo 1.

$\mathrm{O}$ alvo dessa segunda etapa foi aceitar ou rejeitar a hipótese metodológica $\mathbf{H}_{\mathbf{0}, 2}$ : $\mathbf{O}$ beta contábil de uma empresa pode explicar o beta de mercado de suas ações. Observando os resultados da análise de Dados em Painel de Efeitos Fixos não se pode negar que alguns betas contábeis podem explicar o comportamento do beta de mercado. Os resultados indicam que o Beta contábil do crescimento percentual do indicador Market to book, total de endividamento (Passivo Circulante + Exigível a longo prazo) sobre o Patrimônio Líquido, da do Grau de Alavancagem Operacional, do Grau de Alavancagem Financeira, do Lucro Antes do Imposto 
de Renda/Ativo Total e o Beta contábil do indicador financeiro de Liquidez podem explicar o beta de mercado das ações das empresas da amostra.

Entretanto, para os 27 betas testados apenas seis apresentaram poder de explicação. A hipótese $\mathrm{H}_{0,2}$ pôde ser rejeitada.

O terceiro passo foi verificar a terceira hipótese de que $\mathbf{H}_{0,3}$ : $\mathbf{O}$ beta contábil de uma empresa pode antecipar o beta de mercado de suas ações.

Tabela 7 - Betas contábeis $x$ betas de mercado: 4 período a frente - 5 anos

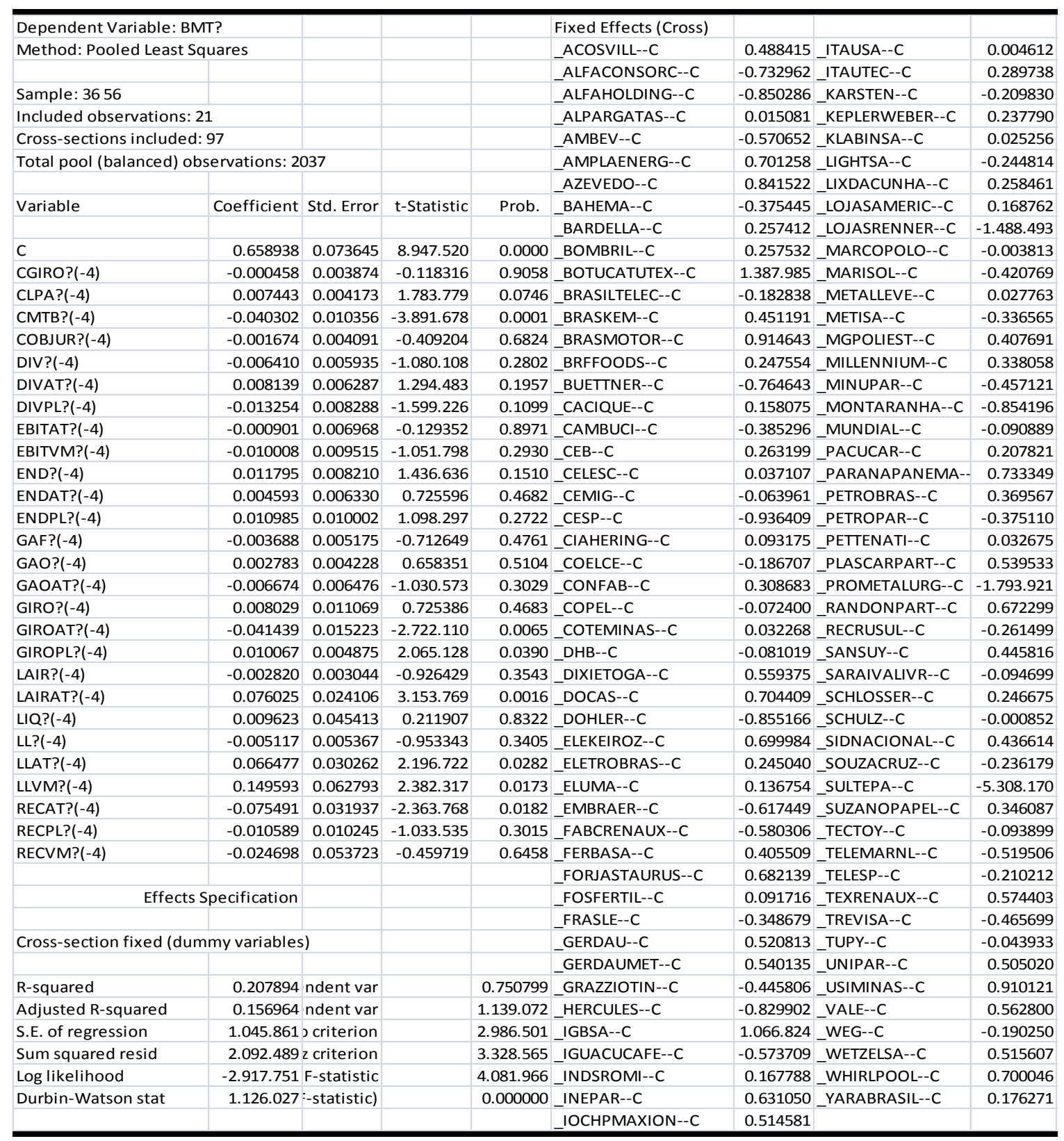

O primeiro teste realizado seguiu a seguinte equação: 


$$
Y_{i t}=\alpha+\beta X_{i t-4}+C_{i t}+U_{i t}
$$

em que: $Y_{i t}$ é a informação da evolução temporal da variável dependente para todos os indivíduos da amostra; $X_{i t-4}$; é a informação da evolução temporal das variáveis independentes para todos os indivíduos da amostra quatro trimestre anterior ao período observado pela variável dependente; $C_{i t}$ efeito fixo no tempo e específico do indivíduo, ou seja, o modelo terá a presença de " $n$ " efeitos fixos (um para cada indivíduo da amostra) e $U_{i t}$ o erro aleatório do modelo. Também, foram selecionados, utilizando o método step wise, apenas os betas contábeis que possuíam significância estatística e testados em painel. Foi testado a normalidade e aplicada a técnica de correção de erros White, o que transformou os resíduos em homocedásticos. Foi verificado através do teste de co-integração que as variáveis possuem um relacionamento (equilíbrio) de longo prazo. Os testes de co-integração estão apresentados no Anexo 1 e confirmam os resultados da tabela 8.

Tabela 8 - Betas contábeis $x$ betas de mercado (Stepwise): 4 período a frente -5 anos

\begin{tabular}{|c|c|c|c|c|c|c|c|c|c|c|}
\hline \multicolumn{2}{|c|}{ Dependent Variable: BMT? } & & & & \multicolumn{2}{|c|}{ Fixed Effects (Cross) } & \multirow[b]{2}{*}{ _ELUMA--C } & \multirow[b]{2}{*}{0.013515} & \multirow[b]{2}{*}{ _MUNDIAL--C } & \multirow[b]{2}{*}{-0.205790} \\
\hline Method: Pooled & east Squares & & & & ACOSVILL--C & 0.363388 & & & & \\
\hline & & & & & ALFACONSORC- & -0.814387 & EMBRAER--C & -0.723213 & _PACUCAR--C & 0.096636 \\
\hline Sample: 3656 & & & & & _ALFAHOLDING-- & -0.980130 & _FABCRENAUX--1 & -0.239883 & _PARANAPANE & 0.493018 \\
\hline \multicolumn{2}{|c|}{ Included observations: 21} & & & & ALPARGATAS--C & -0.090269 & FERBASA--C & 0.292578 & PETROBRAS--1 & -0.135414 \\
\hline \multicolumn{2}{|c|}{ Cross-sections included: 97} & & & & AMBEV--C & -0.683587 & FORJASTAURUS & 0.566039 & _PETROPAR--C & -0.487317 \\
\hline \multicolumn{4}{|c|}{ Total pool (balanced) observations: 2037} & & AMPLAENERG-- & 0.584356 & FOSFERTIL--C & -0.031514 & _PETTENATI--C & -0.078652 \\
\hline \multicolumn{5}{|c|}{ White cross-section standard errors \& covariance (d.f. corrected) } & AZEVEDO--C & 0.667334 & FRASLE--C & -0.470561 & _PLASCARPAR1 & 0.479537 \\
\hline & & & & & BAHEMA--C & -0.471167 & GERDAU--C & 0.348964 & _PROMETALUR & 0.350073 \\
\hline \multirow[t]{2}{*}{ Variable } & Coefficient & Std. Error & t-Statistic & Prob. & BARDELLA--C & 0.146581 & _GERDAUMET--C & 0.399699 & RANDONPAR $^{-}$ & 0.551962 \\
\hline & & & & & BOMBRIL--C & 0.130161 & _GRAZZIOTIN--C & 0.011708 & _RECRUSUL--C & -0.315600 \\
\hline $\mathrm{C}$ & 0.761639 & 0.010164 & 7,493595 & 0.0000 & _BOTUCATUTEX-. & 1.318 .340 & HERCULES--C & -0.174499 & SANSUY--C & 0.508685 \\
\hline CLPA?(-4) & 0.009922 & 0.002215 & 4,480169 & 0.0000 & _BRASILTELEC-C & -0.294322 & IGBSA--C & 0.961515 & _SARAIVALIVR. & 0.241090 \\
\hline СМтВ?(-4) & -0.029669 & 0.010262 & $-2,891085$ & 0.0039 & _BRASKEM--C & 0.339966 & _IGUACUCAFE--C & -0.664552 & _SCHLOSSER--C & 0.227592 \\
\hline DIV?(-4) & -0.007295 & 0.002487 & $-2,933597$ & 0.0034 & _BRASMOTOR--C & 0.802565 & _INDSROMI--C & 0.036083 & _SCHULZ--C & -0.140548 \\
\hline \multirow[t]{2}{*}{ END?(-4) } & 0.012456 & 0.004798 & 2,596141 & 0.0095 & BRFFOODS--C & 0.128246 & _INEPAR--C & 0.555573 & _SIDNACIONAL & 0.295006 \\
\hline & & & & & _BUETTNER--C & -0.667225 & _IOCHPMAXION- & 0.175697 & _SOUZACRUZ-- & -0.364545 \\
\hline R-squared & 0.187543 & \multicolumn{2}{|c|}{ Mean dependent var } & 0.750799 & CACIQUE--C & 0.040632 & ITAUSA--C & -0.135950 & SULTEPA--C & 1.272 .947 \\
\hline Adjusted R-squa & 0.145578 & \multicolumn{2}{|c|}{ S.D. dependent var } & 1,139072 & _CAMBUCI--C & -0.505551 & _ITAUTEC--C & 0.173845 & _SUZANOPAPE & 0.231086 \\
\hline S.E. of regressio & 1.052 .901 & \multicolumn{2}{|c|}{ Akaike info criterion } & 2,989287 & _CEB--C & 0.159320 & _KARSTEN--C & -0.317555 & _TECTOY--C & -0.335575 \\
\hline Sum squared res & 2.146 .250 & \multicolumn{2}{|c|}{ Schwarz criterion } & 3,267903 & _CELESC--C & -0.078346 & _KEPLERWEBER-- & 0.104512 & _TELEMARNL--1 & -0.643305 \\
\hline Log likelihood & -2.943 .588 & \multicolumn{2}{|c|}{ Hannan-Quinn criter } & 3,091494 & _CEMIG--C & -0.178426 & _KLABINSA--C & -0.067966 & _TELESP--C & -0.360269 \\
\hline F-statistic & 4.468 .963 & \multicolumn{2}{|c|}{ Durbin-Watson stat } & 1,106140 & CESP--C & -1.037 .318 & _LIGHTSA--C & -0.355752 & _TEXRENAUX-- & 0.508088 \\
\hline \multirow[t]{11}{*}{ Prob(F-statistic) } & 0.000000 & & & & _CIAHERING--C & -0.119272 & _LIXDACUNHA--C & 0.129705 & _TREVISA--C & -0.677721 \\
\hline & & & & & _COELCE--C & -0.293730 & _LOJASAMERIC-- & 0.055786 & _TUPY--C & -0.168813 \\
\hline & & & & & _CONFAB--C & 0.192386 & _LOJASRENNER-- & -1.505 .441 & _UNIPAR--C & 0.394932 \\
\hline & & & & & _COPEL--C & -0.189618 & _MARCOPOLO--C & -0.136213 & _USIMINAS--C & 0.751725 \\
\hline & & & & & _COTEMINAS--C & -0.070484 & MARISOL--C & -0.536579 & _VALE--C & 0.249721 \\
\hline & & & & & DHB--C & -0.109462 & _METALLEVE--C & -0.094572 & _WEG--C & -0.344396 \\
\hline & & & & & _DIXIETOGA--C & 0.422874 & _METISA--C & -0.426461 & _WETZELSA--C & 0.373011 \\
\hline & & & & & _DOCAS--C & 0.610543 & _MGPOLIEST--C & 0.300072 & _WHIRLPOOL-- & 0.575901 \\
\hline & & & & & _DOHLER--C & -0.933836 & _MILLENNIUM--C & 0.176955 & _YARABRASIL-- & 0.151237 \\
\hline & & & & & ELEKKEIROZ--C & 0.566416 & _MINUPAR--C & -0.596072 & & \\
\hline & & & & & _ELETROBRAS--C & 0.105249 & _MONTARANHA- & -0.380989 & & \\
\hline
\end{tabular}

Os resultados, no período entre o quarto trimestre de 2004 e o terceiro trimestre de 2009, mostraram que a equação do conjunto de betas contábeis é significativa estatisticamente ( $\left.F_{\text {value }} 0,000000\right)$ e explicam $14 \%$ do beta de mercado $\left(R^{2}\right.$ de 0,1455$)$. É interessante perceber 
que até $14 \%$ do beta de mercado do período atual pode ser explicado pelos betas contábeis de um ano atrás. Isto traz indícios de que determinados betas contábeis hoje, podem influenciar betas de mercado futuros. Dentre as variáveis, permaneceram significativas estatisticamente o Beta contábil do crescimento percentual do indicador Market to book, o Beta contábil do total de capital de terceiros (Passivo Circulante + Exigível a longo prazo), o Beta contábil do Lucro por Ação e o Beta contábil da Dívida onerosa. Os dados podem ser observados na Tabela 8.

O propósito dessa terceira etapa foi aceitar ou rejeitar a hipótese metodológica $\mathbf{H}_{\mathbf{0 , 3}}$ : $\mathbf{O}$ beta contábil de uma empresa pode antecipar o beta de mercado de suas ações. Observando os resultados da análise de Dados em Painel de Efeitos Fixos não se pode negar que alguns betas contábeis podem explicar, antecipadamente, o comportamento do beta de mercado. Todavia, para a maioria dos betas contábeis não foi possível verificar esta relação, sendo assim a hipótese $\mathbf{H}_{\mathbf{0 , 3}}$ foi rejeitada.

O quarto procedimento foi testar a hipótese $\mathbf{H}_{\mathbf{0 , 4}}$ de que, "O beta contábil de uma empresa pode melhorar a previsão do beta de mercado de suas ações". Para isso, foi, primeiramente, observado quanto à própria variável dependente, no momento $\mathrm{t}-1$, pode explicar seu comportamento em t. Foi testada a seguinte equação:

$$
Y_{i t}=\alpha+\beta Y_{i t-1}++U_{i t}
$$

em que: $Y_{i t}$ é a informação da evolução temporal da variável dependente para todos os indivíduos da amostra; $Y_{i t}$ é a informação da evolução temporal da variável dependente para todos os indivíduos da amostra no período t-1; e $U_{i t}$ é o erro aleatório do modelo.

Os resultados mostraram que a equação de previsão de betas de mercado é significativa estatisticamente $\left(F_{\text {value }} 0,000000\right)$ e $33 \%$ do beta de mercado $\left(R^{2}\right.$ de 0,3334$)$ pode ser explicado pelos dados dela mesma, um período anterior.

Para verificar hipótese $\mathbf{H}_{\mathbf{0 , 4}}$, foram, então, acrescentados os betas contábeis das variáveis selecionadas. O resultado mostrou que a equação de previsão de betas de mercado é significativa estatisticamente $\left(\mathrm{F}_{\text {value }} 0,000000\right)$ e o poder de explicação da equação aumentou para $39 \%$ do beta de mercado $\left(\mathrm{R}^{2}\right.$ de 0,3945$)$. Apesar de os resultados indicarem uma melhoria no poder de explicação, é possível rejeitar $\mathbf{H}_{\mathbf{0 , 4}}$. Isto ocorre pois há pistas de que "o 
beta contábil de uma empresa pode melhorar a previsão do beta de mercado de suas ações" apenas para um número reduzido de betas contábeis.

Tabela 9 - Previsão de beta de mercado por seus dados históricos

\begin{tabular}{|c|c|c|c|c|}
\hline \multicolumn{5}{|c|}{ Dependent Variable: BMT? } \\
\hline \multicolumn{5}{|c|}{ Method: Pooled Least Squares } \\
\hline \multicolumn{5}{|c|}{ Sample: 3656} \\
\hline \multicolumn{5}{|c|}{ Included observations: 21} \\
\hline \multicolumn{5}{|c|}{ Cross-sections included: 97} \\
\hline \multicolumn{5}{|c|}{ Total pool (balanced) observations: 2037} \\
\hline Variable & Coefficient & Std. Error & t-Statistic & Prob. \\
\hline $\mathrm{C}$ & 0.395596 & 0.025440 & 1.555 .024 & 0.0000 \\
\hline BMT?(-1) & 0.473212 & 0.019879 & 2.380 .477 & 0.0000 \\
\hline \multicolumn{5}{|c|}{ Effects Specification } \\
\hline \multicolumn{5}{|c|}{ Cross-section fixed (dummy variables) } \\
\hline R-squared & 0.365250 & \multicolumn{2}{|c|}{ Mean dependent var } & 0.750799 \\
\hline Adjusted R-squared & 0.333496 & \multicolumn{2}{|c|}{ S.D. dependent var } & 1.139 .072 \\
\hline S.E. of regression & 0.929935 & \multicolumn{2}{|c|}{ Akaike info criterion } & 2.739 .509 \\
\hline Sum squared resid & 1.676 .805 & \multicolumn{2}{|c|}{ Schwarz criterion } & 3.009 .850 \\
\hline Log likelihood & -2.692 .190 & \multicolumn{2}{|l|}{ F-statistic } & 1.150 .255 \\
\hline Durbin-Watson stat & 2.055 .095 & \multicolumn{2}{|c|}{ Prob (F-statistic) } & 0.000000 \\
\hline
\end{tabular}

Do mesmo modo, foram selecionados, utilizando o método stepwise, apenas os betas contábeis que possuíam significância estatística e testados em painel, como pode ser visto na tabela 11. Foi testado a normalidade e aplicada a técnica de correção de erros White, o que transformou os resíduos em homocedásticos. Também foi verificado através do teste de cointegração que as variáveis possuem um relacionamento (equilíbrio) de longo prazo. Os testes de co-integração estão apresentados no Anexo 1 e confirmam os resultados da tabela 11 . 
Tabela 10 - Previsão do beta de mercado por dados históricos e betas contábeis

\begin{tabular}{|c|c|c|c|c|c|c|c|c|}
\hline \multirow{2}{*}{\multicolumn{2}{|c|}{$\begin{array}{l}\text { Dependent Variable: BMT? } \\
\text { Method: Pooled Least Squares }\end{array}$}} & & & & \multicolumn{4}{|c|}{ Fixed Effects (Cross) } \\
\hline & & & & & ACOSVILL--C & 0.171061 & _ITAUSA--C & -0.199735 \\
\hline & & & & & _ALFACONSORC--C & -0.595493 & ITAUTEC--C & 0.055078 \\
\hline Sample: 3656 & & & & & _ALFAHOLDING--C & -0.530066 & KARSTEN--C & -0.173206 \\
\hline \multicolumn{2}{|c|}{ Included observations: 21} & & & & _ALPARGATAS--C & -0.092935 & _KEPLERWEBER--C & 0.049095 \\
\hline \multicolumn{2}{|c|}{ Cross-sections included: 97} & & & & _AMBEV--C & -0.338517 & KLABINSA--C & -0.040283 \\
\hline \multicolumn{3}{|c|}{ Total pool (balanced) observations: 2037} & & & _AMPLAENERG--C & 0.254282 & _LIGHTSA--C & -0.226152 \\
\hline & & & & & _AZEVEDO--C & -0.142211 & _LIXDACUNHA--C & 0.148676 \\
\hline \multirow[t]{2}{*}{ Variable } & Coefficient & Std. Error & t-Statistic & Prob. & _BAHEMA--C & 0.000161 & _LOJASAMERIC--C & -0.110227 \\
\hline & & & & & _BARDELLA--C & 0.023617 & _LOJASRENNER--C & -0.753638 \\
\hline C & 0.411490 & 0.069864 & 5.889 .894 & 0.0000 & BOMBRIL--C & 0.007952 & _MARCOPOLO--C & -0.104939 \\
\hline BMT?(-1) & 0.402518 & 0.019593 & 2.054 .350 & 0.0000 & _BOTUCATUTEX--C & 0.367175 & _MARISOL--C & -0.292006 \\
\hline CGIRO? & -0.004844 & 0.003102 & -1.561 .385 & 0.1186 & BRASILTELEC--C & -0.148064 & _METALLEVE--C & -0.065989 \\
\hline CLPA? & 0.000853 & 0.003313 & 0.257287 & 0.7970 & _BRASKEM--C & 0.185609 & METISA--C & -0.053998 \\
\hline CMTB? & 0.130529 & 0.008534 & 1.529 .605 & 0.0000 & BRASMOTOR--C & 0.123207 & MGPOLIEST--C & 0.139312 \\
\hline COBJUR? & -0.001744 & 0.003201 & -0.544985 & 0.5858 & BRFFOODS--C & 0.088156 & MILLENNIUM--C & 0.131602 \\
\hline DIV? & 0.000660 & 0.003733 & 0.176896 & 0.8596 & _BUETTNER--C & -0.369990 & MINUPAR--C & -0.441383 \\
\hline DIVAT? & 0.006757 & 0.004885 & 1.383 .152 & 0.1668 & _CACIQUE--C & -0.018609 & _MONTARANHA--C & -6.992 .448 \\
\hline DIVPL? & 0.003658 & 0.005734 & 0.637930 & 0.5236 & _CAMBUCl--C & -0.102242 & _MUNDIAL--C & -0.086633 \\
\hline EBITAT? & -0.006590 & 0.005527 & -1.192 .400 & 0.2333 & CEB--C & 0.058753 & PACUCAR--C & 0.062829 \\
\hline EBITVM? & -0.004837 & 0.007956 & -0.608010 & 0.5433 & _CELESC--C & -0.030842 & PARANAPANEMA-- & 0.520459 \\
\hline END? & 0.003038 & 0.006953 & 0.436953 & 0.6622 & CEMIG--C & -0.215488 & _PETROBRAS--C & -0.193640 \\
\hline ENDAT? & 0.003965 & 0.004172 & 0.950281 & 0.3421 & _CESP--C & -0.677728 & _PETROPAR--C & -0.264634 \\
\hline ENDPL? & -0.016520 & 0.006873 & -2.403 .759 & 0.0163 & _CIAHERING--C & -0.101940 & _PETTENATI--C & -0.052725 \\
\hline GAF? & 0.005848 & 0.004352 & 1.343 .846 & 0.1792 & COELLCE--C & -0.160293 & _PLASCARPART--C & 0.372988 \\
\hline GAO? & -0.003542 & 0.002332 & -1.519 .072 & 0.1289 & _CONFAB--C & 0.072218 & _PROMETALURG--C & 2.519 .231 \\
\hline GAOAT? & -0.001503 & 0.005428 & -0.276986 & 0.7818 & _COPEL--C & -0.139064 & RANDONPART--C & 0.278911 \\
\hline GIRO? & 0.025396 & 0.008433 & 3.011 .451 & 0.0026 & _COTEMINAS--C & -0.051272 & _RECRUSUL--C & -0.494652 \\
\hline GIROAT? & -0.022502 & 0.011972 & -1.879 .591 & 0.0603 & DHB--C & -0.145155 & SANSUY--C & 0.019397 \\
\hline GIROPL? & -0.013628 & 0.003761 & -3.622 .948 & 0.0003 & DIXIETOGA--C & 0.165297 & SARAIVALIVR--C & 0.296892 \\
\hline LAIR? & 0.003240 & 0.002709 & 1.195 .758 & 0.2319 & _DOCAS--C & -0.083925 & SCHLOSSER--C & 0.063347 \\
\hline LAIRAT? & -0.044411 & 0.023685 & -1.875 .119 & 0.0609 & _DOHLER--C & -0.504227 & SCHULZ--C & -0.134447 \\
\hline LIQ? & 0.107171 & 0.051364 & 2.086 .526 & 0.0371 & ELEEKEIROZ--C & 0.137000 & SIDNACIONAL--C & 0.141209 \\
\hline LL? & 0.000175 & 0.007565 & 0.023196 & 0.9815 & _ELETROBRAS--C & -0.068919 & _SOUZACRUZ--C & -0.202766 \\
\hline LLAT? & 0.002437 & 0.003495 & 0.697249 & 0.4857 & _ELUMA--C & -0.026982 & SULTEPA--C & 6.980 .178 \\
\hline LLVM? & -0.036136 & 0.040684 & -0.888202 & 0.3745 & EMMBRAER--C & -0.373177 & _SUZANOPAPEL--C & 0.113781 \\
\hline RECAT? & -0.016502 & 0.023809 & -0.693123 & 0.4883 & _FABCRENAUX--C & -0.168488 & _TECTOY--C & -0.417770 \\
\hline RECPL? & -0.023369 & 0.011078 & -2.109 .480 & 0.0350 & _FERBASA--C & 0.118867 & _TELEMARNL--C & -0.347542 \\
\hline \multirow[t]{2}{*}{ RECVM? } & -0.048053 & 0.027996 & -1.716 .461 & 0.0862 & _FORJASTAURUS--C & 0.262282 & _TELESP--C & -0.155295 \\
\hline & & & & & _FOSFERTIL--C & -0.043907 & _TEXRENAUX--C & 0.317116 \\
\hline \multicolumn{2}{|c|}{ Effects Specification } & & & & _FRASLE--C & -0.144524 & -TREVISA--C & -0.373898 \\
\hline & & & & & _GERDAU--C & 0.163864 & _TUPY--C & -0.132840 \\
\hline \multicolumn{3}{|c|}{ Cross-section fixed (dummy variables) } & & & _GERDAUMET--C & 0.203630 & _UNIPAR--C & 0.163565 \\
\hline & & & & & _GRAZZIOTIN--C & 0.230213 & _USIMINAS--C & 0.327270 \\
\hline R-squared & 0.444084 & \multicolumn{2}{|c|}{ Mean dependent var } & 0.750799 & _HERCULES--C & 0.504638 & _VALE--C & -0.030123 \\
\hline Adjusted R-squared & 0.408031 & \multicolumn{2}{|c|}{ S.D. dependent var } & 1.139 .072 & IGBSA--C & 0.753591 & -WEG--C & -0.171018 \\
\hline S.E. of regression & 0.876397 & \multicolumn{2}{|c|}{ Akaike info criterion } & 2.633 .406 & _IGUACUCAFE--C & -0.289925 & _WETZELSA--C & 0.114869 \\
\hline Sum squared resid & 1.468 .552 & \multicolumn{2}{|c|}{ Schwarz criterion } & 2.978 .228 & INDSROMI--C & -0.038951 & _WHIRLPOOL--C & 0.244297 \\
\hline Log likelihood & -2.557 .124 & \multicolumn{2}{|c|}{ F-statistic } & 1.231 .748 & _INEPAR--C & 0.721021 & _YARABRASIL--C & 0.190049 \\
\hline Durbin-Watson stat & 1.935 .738 & \multicolumn{2}{|c|}{ Prob(F-statistic) } & 0.000000 & _IOCHPMAXION--C & 0.252172 & & \\
\hline
\end{tabular}


Tabela 11 - Previsão do beta de mercado por dados históricos e betas contábeis (Stepwise)

\begin{tabular}{|c|c|c|c|c|c|c|c|c|c|c|}
\hline \multirow{2}{*}{\multicolumn{3}{|c|}{$\begin{array}{l}\text { Dependent Variable: BMT? } \\
\text { Method: Pooled Least Squares }\end{array}$}} & & & \multicolumn{2}{|c|}{ Fixed Effects (Cross) } & \multirow[b]{2}{*}{ EMBRAER--C } & \multirow[b]{2}{*}{-0.234415} & \multirow[b]{2}{*}{ PARANAPAN } & \multirow[b]{2}{*}{0.289886} \\
\hline & & & & & ACOSVILL--C & 0.299543 & & & & \\
\hline & & & & & ALFACONSORC & -0.456350 & FABCRENAUX- & -0.340920 & PETROBRAS-- & 0.046006 \\
\hline Sample: 3656 & & & & & _ALFAHOLDING. & -0.536580 & _FERBASA--C & 0.160892 & _PETROPAR--C & -0.150075 \\
\hline \multicolumn{2}{|c|}{ Included observations: 21} & & & & ALPARGATAS-- & -0.059425 & _FORJASTAURU & 0.392852 & _PETTENATI--C & 0.086232 \\
\hline \multicolumn{2}{|c|}{ Cross-sections included: 97} & & & & AMBEV--C & -0.206432 & _FOSFERTIL--C & 0.093503 & PLASCARPAR & 0.480291 \\
\hline \multicolumn{5}{|c|}{ Total pool (balanced) observations: 2037} & _AMPLAENERG- & -0.383420 & _FRASLE--C & -0.021811 & PROMETALUF & 0.409501 \\
\hline \multicolumn{6}{|c|}{ White cross-section standard errors \& covariance (d.f. correcte_AZEVEDO--C } & -0.031636 & GERDAU--C & 0.319205 & RANDONPAR & 0.414466 \\
\hline & & & & & BAHEMA--C & 0.092652 & _GERDAUMET-- & 0.349860 & RECRUSUL--C & -0.407977 \\
\hline \multirow[t]{2}{*}{ Variable } & Coefficient & Std. Error & t-Statistic & Prob. & BARDELLA--C & 0.171840 & _GRAZZIOTIN--1 & 0.061220 & SANSUY--C & 0.012155 \\
\hline & & & & & BOMBRIL--C & 0.147974 & _HERCULES--C & 0.021353 & SARAIVALIVR & 0.187918 \\
\hline $\mathrm{C}$ & 0.265775 & 0.079913 & 3,325786 & 0.0009 & _BOTUCATUTEX & 0.300323 & _IGBSA--C & 0.876813 & SCHLOSSER--1 & 0.201138 \\
\hline BMT?(-1) & 0.422282 & 0.120482 & 3,504935 & 0.0005 & \multicolumn{2}{|c|}{ BRASILTELEC--1-0.024238 } & IGUACUCAFE-- & -0.194011 & SCHULZ--C & 0.043268 \\
\hline CMTB? & 0.110323 & 0.041662 & 2,648053 & 0.0082 & BRASKEM--C & 0.305403 & INDSROMI--C & 0.103104 & SIDNACIONA & 0.272599 \\
\hline LAIR? & 0.002986 & 0.001384 & 2,157318 & 0.0311 & BRASMOTOR-- & 0.243241 & INEPAR--C & 0.365492 & SOUZACRUZ- & -0.062186 \\
\hline \multirow[t]{3}{*}{ LIQ? } & 0.110710 & 0.036064 & 3,069856 & 0.0022 & BRFFOODS--C & 0.224073 & _IOCHPMAXION & 0.198426 & SULTEPA--C & 0.697148 \\
\hline & & & & & BUETTNER--C & -0.533825 & ITAUSA--C & 0.035086 & SUZANOPAPE & 0.246309 \\
\hline & & & & & CACIQUE--C & 0.124832 & _ITAUTEC--C & 0.193389 & _TECTOY--C & -0.337287 \\
\hline R-squared & 0.424296 & \multicolumn{2}{|c|}{ Mean dependent I } & 0.750799 & CAMBUCl--C & 0.031996 & KAARSTEN--C & -0.039037 & _TELEMARNL-- & -0.201214 \\
\hline Adjusted R-squa & 0.394560 & \multicolumn{2}{|c|}{ S.D. dependent va } & 1,139072 & CEB--C & 0.185012 & KEPPLERWEBER & 0.161446 & _TELESP--C & -0.089571 \\
\hline S.E. of regressior & 0.886312 & & 2,644817 & CELESC--C & 0.096194 & KLABINSA--C & 0.094631 & _TEXRENAUX-- & 0.027585 \\
\hline Sum squared res & 1.520 .824 & \multicolumn{2}{|c|}{ Schwarz criterion } & 2,923434 & CEMIG--C & 0.003310 & _LIGHTSA--C & -0.086365 & _TREVISA--C & -0.252339 \\
\hline Log likelihood & -2.592 .746 & \multicolumn{2}{|c|}{ Hannan-Quinn crit } & 2,747024 & CESP--C & -0.512339 & _LIXDACUNHA- & 0.214255 & _TUPY--C & 0.021699 \\
\hline F-statistic & 1.426 .842 & \multicolumn{2}{|c|}{ Durbin-Watson sta } & 1,934904 & CIAHERING--C & -0.113219 & LOJASAMERIC & 0.040746 & UNIPAR--C & 0.317248 \\
\hline \multirow[t]{11}{*}{ Prob(F-statistic) } & 0.000000 & & & & _COELCE--C & -0.025443 & LOJASRENNER & -0.666762 & _USIMINAS--C & 0.466107 \\
\hline & & & & & _CONFAB--C & 0.203590 & _MARCOPOLO- & 0.062180 & _VALE--C & 0.153553 \\
\hline & & & & & COPPE--C & -0.002237 & MARISOL--C & -0.149891 & _WEG--C & -0.035791 \\
\hline & & & & & _COTEMINAS--C & 0.078824 & _METALLEVE--C & 0.059829 & _WETZELSA--C & 0.266518 \\
\hline & & & & & DHB--C & -0.147459 & _METISA--C & -0.080159 & _WHIRLPOOL- & 0.388911 \\
\hline & & & & & _DIXIETOGA--C & 0.314493 & _MGPOLIEST--C & 0.256342 & _YARABRASIL- & 0.237775 \\
\hline & & & & & DOCAS--C & 0.107693 & MILLENNIUM- & 0.213289 & & \\
\hline & & & & & DOHLER--C & -0.371343 & _MINUPAR--C & -0.278554 & & \\
\hline & & & & & _ELEKEIROZ--C & 0.290684 & \multicolumn{2}{|c|}{ MONTARANH, $-7.091 .784$} & & \\
\hline & & & & & _ELETROBRAS--1 & 0.135051 & _MUNDIAL--C & 0.032374 & & \\
\hline & & & & & _ELUMA--C & 0.113589 & _PACUCAR--C & 0.195489 & & \\
\hline
\end{tabular}

Esse resultado confirma os resultados de Oda (2004), em que foram encontradas fortes evidências de que os indicadores contábeis podem ser utilizados para melhorar a previsão de betas de mercado, principalmente, quando associados a betas históricos. 
Os resultados da verificação das hipóteses de $\mathbf{H}_{\mathbf{0 , 1},}, \mathbf{H}_{\mathbf{0 , 2},}, \mathbf{H}_{\mathbf{0 , 3}}$ e $\mathbf{H}_{\mathbf{0 , 4}}$ estão de acordo com estudos anteriores feitos no exterior que não encontraram relação significativa ou encontraram baixos $\mathrm{R}^{2}$ ou, ainda, encontraram grande parte dos coeficientes estatisticamente não diferentes de zero como os de Breen e Lerner (1973), Elgers (1980), Gonedes (1973), Lev (1974), StPierre e Bahri (2006).

No Brasil, estudos como os de Cupertino e Ogliari (2002), Gusmão e Cherobim (2009), Mendonça Neto e Bruni (2004), Minardi et al. (2007), Munhoz (2006) e Ribeiro Neto e Famá (2001) não apresentaram relação entre as variáveis contábeis e betas contábeis, como o beta ROA, ou que apresentaram resultados não significativos que também foram corroborados por este trabalho.

Os resultados mostraram que, dentre as variáveis de rentabilidade, o beta contábil do Lucro Antes do Imposto de Renda/Ativo Total possui poder de explicação do beta de mercado. Esse resultado confirma o encontrado por Ball e Brown (1969), Ball et al. (1993), Beaver et al. (1970), Beaver e Manegold (1975), Bildersee (1975), Bowman (1979), Brimble e Hodgson (2007), Dechow (1994), Pettit e Westerfield (1972), Rosenberg e Mckibben (1973), Teixeira e Valle (2008) e Thompson (1976).

Dentre as variáveis consideradas neste estudo como operacionais, os betas contábeis do crescimento percentual do indicador Market to book e da Receita Líquida sobre o Ativo Total apresentaram, na maioria dos testes, poder de explicação do beta de mercado. Esse resultado vai ao encontro dos estudos de Hill e Stone (1980), Lev e Kunitzky (1974) e Thompson (1976).

As variáveis financeiras foram as que mais apresentaram relação com o beta de mercado dentre elas se destacaram:

- Beta do endividamento medido pelo total de capital de terceiros sobre o Patrimônio Líquido - De acordo com Hamada (1971) e Hill e Stone (1980).

- Beta do Grau de Alavancagem Operacional - Conforme Beaver et al. (1970), Bowman (1979), Hill e Stone (1980), Mandelker e Rhee (1984) e Ilha et al. (2009).

- Beta do Grau de Alavancagem Financeira - De acordo com Beaver et al. (1970), Bowman (1979), Brimble e Hodgson (2007), Hill e Stone (1980), Ilha et al. (2009), 
Mandelker e Rhee (1984), Oda (2004), Rosenberg e Mckibben (1973) e Thompson (1976).

- Beta contábil do indicador financeiro de Liquidez - Corroborando com Beaver et al. (1970), Bildersee (1975), Hill e Stone (1980) e Ilha et al. (2009)

O próximo passo deste trabalho foi verificar se os betas contábeis e os betas de mercado possuem os mesmos componentes, podendo o beta contábil cooperar na estimação do risco de uma empresa. Caso os betas contábeis e de mercado possuam componentes comuns e esses componentes comuns sejam correlacionados (por meio de correlação canônica), poder-se-á entender que esse componente é o mesmo, de acordo com Ball et al. (2009) e Connor e Korajczyk (1987). O estudo de Ball et al. (2009) demonstrou, por intermédio de uma Análise de Componentes Principais, que fatores comuns explicam uma porção substancial da variação nos lucros. Os retornos das ações, também, foram observados com componentes comuns. Somado a isso, foi encontrado que os componentes principais dos lucros e dos retornos eram altamente correlacionados, implicando que existe uma forte relação entre os fatores comuns de um e de outro. Os autores consideraram que a evidência, de que os fatores eram correlacionados, demonstrava não só uma relação, mas que esses fatores eram os mesmos.

O primeiro passo para atingir estes objetivos específicos foi constatar a hipótese:

\section{$\mathrm{H}_{0,5}$ : Os betas contábeis e betas de mercado possuem componentes comuns.}

Para encontrar componentes comuns entre as empresas presentes dentro de cada beta contábil e do beta de mercado foi realizada a Análise de Componentes Principais. Nesse momento, para atingi-la, foram testados os requisitos para a Análise de Componentes Principais.

Essa análise foi realizada para o beta de mercado e para os betas contábeis. Para os betas contábeis foram selecionados os seis betas contábeis resultados das sub-hipóteses analisadas em dados em painel, a saber: 
CMBT - Beta Contábil da Variação Percentual de Market to book;

ENDPL - Beta contábil do total de capital de terceiros (Passivo Circulante + Exigível a longo prazo) sobre o Patrimônio Líquido;

LAIRAT - Beta do Lucro Antes do Imposto de Renda sobre o Ativo Total;

GAO - Beta contábil da Alavancagem Operacional;

LIQ - Beta contábil do indicador financeiro de Liquidez

GAF - Beta contábil do grau de Alavancagem Financeira.

Para o resumo dos dados, serão apresentados os testes apenas para a amostra do beta de mercado das 97 empresas selecionadas; os demais resultados estão colocados no Anexo 1.

Primeiramente, foi preciso analisar as Comunalidades entre as variáveis das empresas, que mostram o total de correlação entre cada empresa e as demais. Esse número deve ser maior que 0,70 . Devido à sua extensão, também será apresentada, apenas, parte da tabela resultado do teste, como exemplo.

Tabela 6 - Comunalidade: beta de mercado

\begin{tabular}{lcclll}
\hline \multicolumn{5}{c}{ Communalities } \\
\hline VAR00001 & 1 & 0,98 & VAR00050 & 1 & 0,99 \\
VAR00002 & 1 & 0,97 & VAR00051 & 1 & 0,99 \\
VAR00003 & 1 & 0,86 & VAR00052 & 1 & 0,97 \\
VAR00004 & 1 & 0,98 & VAR00053 & 1 & 0,94 \\
VAR00005 & 1 & 0,98 & VAR00054 & 1 & 0,99 \\
VAR00006 & 1 & 0,99 & VAR00055 & 1 & 0,98 \\
VAR00007 & 1 & 0,86 & VAR00056 & 1 & 0,97 \\
VAR00008 & 1 & 0,83 & VAR00057 & 1 & 0,99 \\
VAR00009 & 1 & 0,99 & VAR00058 & 1 & 0,92 \\
VAR00010 & 1 & 0,99 & VAR00059 & 1 & 0,99 \\
VAR00011 & 1 & 0,81 & VAR00060 & 1 & 0,94 \\
VAR00012 & 1 & 0,99 & VAR00061 & 1 & 0,99 \\
VAR00013 & 1 & 0,99 & VAR00062 & 1 & 0,95 \\
VAR00014 & 1 & 0,99 & VAR00063 & 1 & 0,98 \\
VAR00015 & 1 & 0,73 & VAR00064 & 1 & 0,91 \\
VAR00016 & 1 & 0,90 & VAR00065 & 1 & 0,86 \\
VAR00017 & 1 & 0,95 & VAR00066 & 1 & 0,97 \\
VAR00018 & 1 & 0,89 & VAR00067 & 1 & 0,92 \\
VAR00019 & 1 & 0,95 & VAR00068 & 1 & 0,99 \\
VAR00020 & 1 & 0,99 & VAR00069 & 1 & 0,92 \\
VAR00021 & 1 & 0,99 & VAR00070 & 1 & 0,99 \\
VAR00022 & 1 & 0,46 & VAR00071 & 1 & 0,85 \\
VAR00023 & 1 & 0,95 & VAR00072 & 1 & 0,98 \\
VAR00024 & 1 & 0,76 & VAR00073 & 1 & 0,91 \\
VAR00025 & 1 & 0,97 & VAR00074 & 1 & 0,97 \\
VAR00026 & 1 & 0,94 & VAR00075 & 1 & 1,00 \\
VAR00027 & 1 & 0,98 & VAR00076 & 1 & 0,92 \\
VAR00028 & 1 & 0,80 & VAR00077 & 1 & 0,99 \\
\hline & & \multicolumn{5}{c}{1} & \\
\hline
\end{tabular}




\begin{tabular}{cccccc}
\hline VAR00029 & 1 & 0,98 & VAR00078 & 1 & 0,98 \\
\hline & & & & & \\
\hline VAR00030 & 1 & 0,98 & VAR00079 & 1 & 0,98 \\
VAR00031 & 1 & 0,74 & VAR00080 & 1 & 0,93 \\
VAR00032 & 1 & 0,98 & VAR00081 & 1 & 0,99 \\
VAR00033 & 1 & 0,99 & VAR00082 & 1 & 0,98 \\
VAR00034 & 1 & 0,89 & VAR00083 & 1 & 0,97 \\
VAR00035 & 1 & 0,94 & VAR00084 & 1 & 0,99 \\
VAR00036 & 1 & 0,92 & VAR00085 & 1 & 0,85 \\
VAR00037 & 1 & 0,99 & VAR00086 & 1 & 0,94 \\
VAR00038 & 1 & 0,96 & VAR00087 & 1 & 1,00 \\
VAR00039 & 1 & 0,99 & VAR00088 & 1 & 0,98 \\
VAR00040 & 1 & 0,93 & VAR00089 & 1 & 0,91 \\
VAR00041 & 1 & 1,00 & VAR00090 & 1 & 0,97 \\
VAR00042 & 1 & 0,99 & VAR00091 & 1 & 1,00 \\
VAR00043 & 1 & 0,98 & VAR00092 & 1 & 1,00 \\
VAR00044 & 1 & 0,91 & VAR00093 & 1 & 0,99 \\
VAR00045 & 1 & 0,94 & VAR00094 & 1 & 0,96 \\
VAR00046 & 1 & 0,95 & VAR00095 & 1 & 0,98 \\
VAR00047 & 1 & 0,97 & VAR00096 & 1 & 0,99 \\
VAR00048 & 1 & 0,99 & VAR00097 & 1 & 0,98 \\
VAR00049 & 1 & 0,95 & VAR00098 & 1 & 1,00 \\
\hline Extraction Method: Principal Component Analysis
\end{tabular}

Aplicados os requisitos, o próximo passo foi rodar a Análise de Componentes Principais e analisar seus resultados. Nas Tabelas, a seguir, serão apresentados e comentados os resultados para os betas contábeis e para o beta de mercado.

Tabela 7 - Fatores comuns: Betas de mercado

\begin{tabular}{|c|c|c|c|c|c|c|c|c|c|}
\hline \multicolumn{10}{|c|}{ Total Variance Explained } \\
\hline \multicolumn{10}{|c|}{ BETA DE MERCADO } \\
\hline \multirow[t]{2}{*}{ Component } & \multicolumn{3}{|c|}{ Initial Eigenvalues } & \multicolumn{3}{|c|}{$\begin{array}{c}\text { Extraction Sums of Squared } \\
\text { Loadings }\end{array}$} & \multicolumn{3}{|c|}{$\begin{array}{c}\text { Rotation Sums of Squared } \\
\text { Loadings }\end{array}$} \\
\hline & Total & $\begin{array}{c}\text { \%of } \\
\text { Variance }\end{array}$ & $\begin{array}{c}\text { Cumulative } \\
\%\end{array}$ & Total & $\begin{array}{c}\% \text { of } \\
\text { Variance }\end{array}$ & $\begin{array}{c}\text { Cumulative } \\
\%\end{array}$ & Total & $\begin{array}{c}\text { \% of } \\
\text { Variance }\end{array}$ & $\begin{array}{c}\text { Cumulative } \\
\%\end{array}$ \\
\hline 1 & 85,8052 & 88,4590 & 88,4590 & 85,8052 & 88,4590 & 88,4590 & 77,0105 & 79,3923 & 79,3923 \\
\hline 2 & 1,8405 & 1,8974 & 90,3565 & 1,8405 & 1,8974 & 90,3565 & 6,0622 & 6,2497 & 85,6420 \\
\hline 3 & 1,5735 & 1,6222 & 91,9787 & 1,5735 & 1,6222 & 91,9787 & 4,0149 & 4,1391 & 89,7811 \\
\hline 4 & 1,2353 & 1,2735 & 93,2521 & 1,2353 & 1,2735 & 93,2521 & 3,0159 & 3,1092 & 92,8903 \\
\hline 5 & 1,1302 & 1,1652 & 94,4173 & 1,1302 & 1,1652 & 94,4173 & 1,4812 & 1,5270 & 94,4173 \\
\hline 6 & 0,8222 & 0,8476 & 95,2649 & & & & & & \\
\hline 7 & 0,6294 & 0,6489 & 95,9138 & & & & & & \\
\hline 8 & 0,5220 & 0,5381 & 96,4519 & & & & & & \\
\hline 9 & 0,5088 & 0,5245 & 96,9764 & & & & & & \\
\hline 10 & 0,4489 & 0,4628 & 97,4393 & & & & & & \\
\hline
\end{tabular}


Tabela 8 - Fatores comuns: Beta da \%MTB

\begin{tabular}{|c|c|c|c|c|c|c|c|c|c|}
\hline \multicolumn{10}{|c|}{ Total Variance Explained } \\
\hline \multicolumn{10}{|c|}{$\% \mathrm{MTB}$} \\
\hline \multirow[t]{2}{*}{ Component } & \multicolumn{3}{|c|}{ Initial Eigenvalues } & \multicolumn{3}{|c|}{$\begin{array}{c}\text { Extraction Sums of Squared } \\
\text { Loadings }\end{array}$} & \multicolumn{3}{|c|}{$\begin{array}{c}\text { Rotation Sums of Squared } \\
\text { Loadings }\end{array}$} \\
\hline & Total & $\begin{array}{c}\% \text { of } \\
\text { Variance }\end{array}$ & $\begin{array}{c}\text { Cumulative } \\
\%\end{array}$ & Total & $\begin{array}{c}\% \text { of } \\
\text { Variance }\end{array}$ & $\begin{array}{c}\text { Cumulative } \\
\%\end{array}$ & Total & $\begin{array}{c}\text { \% of } \\
\text { Variance }\end{array}$ & $\begin{array}{c}\text { Cumulative } \\
\%\end{array}$ \\
\hline 1 & 72,4419 & 74,6823 & 74,6823 & 72,4419 & 74,6823 & 74,6823 & 66,0914 & 68,1355 & 68,1355 \\
\hline 2 & 4,0345 & 4,1593 & 78,8416 & 4,0345 & 4,1593 & 78,8416 & 6,1974 & 6,3890 & 74,5245 \\
\hline 3 & 3,3276 & 3,4305 & 82,2722 & 3,3276 & 3,4305 & 82,2722 & 4,5037 & 4,6430 & 79,1675 \\
\hline 4 & 2,7307 & 2,8152 & 85,0873 & 2,7307 & 2,8152 & 85,0873 & 2,8214 & 2,9086 & 82,0761 \\
\hline 5 & 1,9202 & 1,9796 & 87,0669 & 1,9202 & 1,9796 & 87,0669 & 2,7181 & 2,8022 & 84,8783 \\
\hline 6 & 1,6687 & 1,7203 & 88,7872 & 1,6687 & 1,7203 & 88,7872 & 2,5278 & 2,6060 & 87,4843 \\
\hline 7 & 1,5317 & 1,5790 & 90,3662 & 1,5317 & 1,5790 & 90,3662 & 2,0076 & 2,0697 & 89,5540 \\
\hline 8 & 1,2663 & 1,3054 & 91,6716 & 1,2663 & 1,3054 & 91,6716 & 1,6662 & 1,7178 & 91,2718 \\
\hline 9 & 1,1240 & 1,1587 & 92,8304 & 1,1240 & 1,1587 & 92,8304 & 1,5118 & 1,5586 & 92,8304 \\
\hline 10 & 0,8624 & 0,8890 & 93,7194 & & & & & & \\
\hline
\end{tabular}

Extraction Method: Principal Component Analysis.

Tabela 9 - Fatores comuns: Beta do Endividamento sobre o patrimônio líquido

\begin{tabular}{|c|c|c|c|c|c|c|c|c|c|}
\hline \multicolumn{10}{|c|}{ Total Variance Explained } \\
\hline \multicolumn{10}{|c|}{ ENDPL } \\
\hline \multirow[t]{2}{*}{ Component } & \multicolumn{3}{|c|}{ Initial Eigenvalues } & \multicolumn{3}{|c|}{$\begin{array}{c}\text { Extraction Sums of } \\
\text { Squared Loadings }\end{array}$} & \multicolumn{3}{|c|}{$\begin{array}{c}\text { Rotation Sums of Squared } \\
\text { Loadings }\end{array}$} \\
\hline & Total & $\begin{array}{c}\text { \%of } \\
\text { Variance }\end{array}$ & $\begin{array}{c}\text { Cumulative } \\
\%\end{array}$ & Total & $\begin{array}{c}\text { \%of } \\
\text { Variance }\end{array}$ & $\begin{array}{c}\text { Cumulative } \\
\%\end{array}$ & Total & $\begin{array}{c}\text { \%of } \\
\text { Variance }\end{array}$ & $\begin{array}{c}\text { Cumulative } \\
\%\end{array}$ \\
\hline 1 & 21,5216 & 22,1872 & 22,1872 & 21,5216 & 22,1872 & 22,1872 & 15,0982 & 15,5652 & 15,5652 \\
\hline 2 & 12,1288 & 12,5039 & 34,6911 & 12,1288 & 12,5039 & 34,6911 & 15,0815 & 15,5480 & 31,1132 \\
\hline 3 & 11,1119 & 11,4556 & 46,1467 & 11,1119 & 11,4556 & 46,1467 & 12,8949 & 13,2937 & 44,4069 \\
\hline 4 & 7,2886 & 7,5140 & 53,6606 & 7,2886 & 7,5140 & 53,6606 & 7,2844 & 7,5097 & 51,9166 \\
\hline 5 & 6,2833 & 6,4776 & 60,1382 & 6,2833 & 6,4776 & 60,1382 & 5,8006 & 5,9800 & 57,8967 \\
\hline 6 & 5,0176 & 5,1727 & 65,3110 & 5,0176 & 5,1727 & 65,3110 & 4,7243 & 4,8704 & 62,7671 \\
\hline 7 & 4,3526 & 4,4872 & 69,7982 & 4,3526 & 4,4872 & 69,7982 & 3,9775 & 4,1005 & 66,8676 \\
\hline 8 & 3,8700 & 3,9897 & 73,7879 & 3,8700 & 3,9897 & 73,7879 & 3,9585 & 4,0809 & 70,9485 \\
\hline 0 & 3,2653 & 3,3663 & 77,1542 & 3,2653 & 3,3663 & 77,1542 & 3,9412 & 4,0630 & 75,0115 \\
\hline 10 & 2,8701 & 2,9588 & 80,1131 & 2,8701 & 2,9588 & 80,1131 & 2,7727 & 2,8584 & 77,8699 \\
\hline
\end{tabular}

Tabela 10 - Fatores comuns: Beta do LAIR sobre o ativo total

\begin{tabular}{|c|c|c|c|c|c|c|c|c|c|}
\hline \multicolumn{10}{|c|}{ Total Variance Explained } \\
\hline \multicolumn{10}{|c|}{ LAIRAT } \\
\hline Component & \multicolumn{3}{|c|}{ Initial Eigenvalues } & \multicolumn{3}{|c|}{$\begin{array}{l}\text { Extraction Sums of } \\
\text { Squared Loadings }\end{array}$} & \multicolumn{3}{|c|}{$\begin{array}{c}\text { Rotation Sums of Squared } \\
\text { Loadings }\end{array}$} \\
\hline & Total & $\begin{array}{c}\text { \%of } \\
\text { Variance }\end{array}$ & $\begin{array}{c}\text { Cumulative } \\
\%\end{array}$ & Total & $\begin{array}{c}\text { \%of } \\
\text { Variance }\end{array}$ & $\begin{array}{c}\text { Cumulative } \\
\%\end{array}$ & Total & $\begin{array}{c}\text { \%of } \\
\text { Variance }\end{array}$ & $\begin{array}{c}\text { Cumulative } \\
\%\end{array}$ \\
\hline 1 & 60,7412 & 62,6198 & 62,6198 & 60,7412 & 62,6198 & 62,6198 & 51,4342 & 53,0249 & 53,0249 \\
\hline 2 & 9,8911 & 10,1970 & 72,8168 & 9,8911 & 10,1970 & 72,8168 & 12,8210 & 13,2176 & 66,2425 \\
\hline 3 & 6,2074 & 6,3993 & 79,2161 & 6,2074 & 6,3993 & 79,2161 & 9,9133 & 10,2199 & 76,4624 \\
\hline 4 & 5,2457 & 5,4079 & 84,6240 & 5,2457 & 5,4079 & 84,6240 & 6,3407 & 6,5368 & 82,9992 \\
\hline
\end{tabular}




\begin{tabular}{cccccccccc}
5 & 3,3942 & 3,4991 & 88,1232 & 3,3942 & 3,4991 & 88,1232 & 3,5843 & 3,6951 & 86,6943 \\
6 & 3,0151 & 3,1083 & 91,2315 & 3,0151 & 3,1083 & 91,2315 & 2,7645 & 2,8500 & 89,5443 \\
7 & 1,5823 & 1,6313 & 92,8627 & 1,5823 & 1,6313 & 92,8627 & 2,1591 & 2,2259 & 91,7702 \\
8 & 1,4186 & 1,4625 & 94,3252 & 1,4186 & 1,4625 & 94,3252 & 1,8740 & 1,9320 & 93,7022 \\
9 & 1,0847 & 1,1183 & 95,4435 & 1,0847 & 1,1183 & 95,4435 & 1,6891 & 1,7413 & 95,4435 \\
10 & 0,8322 & 0,8579 & 96,3014 & & & & & & \\
\hline
\end{tabular}

Extraction Method: Principal Component Analysis.

Tabela 11 - Fatores comuns: Beta do Grau de Alavancagem Operacional

\begin{tabular}{c|c|c|c|c|c|c|c|c|c}
\hline \multicolumn{10}{c}{ Total Variance Explained } \\
\hline \multirow{2}{*}{ Component } & \multicolumn{10}{c|}{ GAO } \\
\hline & Initial Eigenvalues & \multicolumn{2}{c}{$\begin{array}{c}\text { Extraction Sums of } \\
\text { Squared Loadings }\end{array}$} & \multicolumn{3}{c}{$\begin{array}{c}\text { Rotation Sums of } \\
\text { Squared Loadings }\end{array}$} \\
\hline & Total & $\begin{array}{c}\text { \%of } \\
\text { Variance }\end{array}$ & $\begin{array}{c}\text { Cumulative } \\
\text { \% }\end{array}$ & Total & $\begin{array}{c}\text { \%of } \\
\text { Variance }\end{array}$ & $\begin{array}{c}\text { Cumulative } \\
\text { \% }\end{array}$ & Total & $\begin{array}{c}\text { \%of } \\
\text { Variance }\end{array}$ & $\begin{array}{c}\text { Cumulative } \\
\text { \% }\end{array}$ \\
\hline 1 & 17,5186 & 18,0604 & 18,0604 & 17,5186 & 18,0604 & 18,0604 & 15,1768 & 15,6462 & 15,6462 \\
2 & 15,1911 & 15,6609 & 33,7213 & 15,1911 & 15,6609 & 33,7213 & 14,1671 & 14,6052 & 30,2514 \\
3 & 12,2751 & 12,6547 & 46,3760 & 12,2751 & 12,6547 & 46,3760 & 11,8904 & 12,2582 & 42,5096 \\
4 & 5,8275 & 6,0078 & 52,3838 & 5,8275 & 6,0078 & 52,3838 & 5,8169 & 5,9968 & 48,5064 \\
5 & 5,1717 & 5,3316 & 57,7154 & 5,1717 & 5,3316 & 57,7154 & 5,4351 & 5,6032 & 54,1096 \\
6 & 4,6956 & 4,8409 & 62,5563 & 4,6956 & 4,8409 & 62,5563 & 5,0625 & 5,2191 & 59,3286 \\
7 & 4,2862 & 4,4188 & 66,9751 & 4,2862 & 4,4188 & 66,9751 & 4,4412 & 4,5786 & 63,9072 \\
8 & 3,6932 & 3,8074 & 70,7825 & 3,6932 & 3,8074 & 70,7825 & 4,2181 & 4,3485 & 68,2558 \\
9 & 3,6016 & 3,7130 & 74,4955 & 3,6016 & 3,7130 & 74,4955 & 3,5651 & 3,6754 & 71,9312 \\
10 & 3,3750 & 3,4793 & 77,9749 & 3,3750 & 3,4793 & 77,9749 & 3,0814 & 3,1767 & 75,1078 \\
\hline
\end{tabular}

Extraction Method: Principal Component Analysis.

Tabela 12 - Fatores comuns: Beta do Indicador de Liquidez

\begin{tabular}{c|c|c|c|c|c|c|c|c|c}
\hline \multicolumn{10}{c}{ Total Variance Explained } \\
\hline \multirow{2}{*}{ Component } & \multicolumn{10}{c|}{ Initial Eigenvalues } & \multicolumn{1}{c}{$\begin{array}{c}\text { Extraction Sums of } \\
\text { Squared Loadings }\end{array}$} & \multicolumn{2}{c}{$\begin{array}{c}\text { Rotation Sums of Squared } \\
\text { Loadings }\end{array}$} \\
\hline & Total & $\begin{array}{c}\text { \%of } \\
\text { Variance }\end{array}$ & $\begin{array}{c}\text { Cumulative } \\
\text { \% }\end{array}$ & Total & $\begin{array}{c}\text { \%of } \\
\text { Variance }\end{array}$ & $\begin{array}{c}\text { Cumulative } \\
\text { \% }\end{array}$ & Total & $\begin{array}{c}\text { \%of } \\
\text { Variance }\end{array}$ & $\begin{array}{c}\text { Cumulative } \\
\text { \% }\end{array}$ \\
\hline & 21,9098 & 22,5875 & 22,5875 & 21,9098 & 22,5875 & 22,5875 & 21,9098 & 22,5875 & 22,5875 \\
2 & 10,3970 & 10,7186 & 33,3060 & 10,3970 & 10,7186 & 33,3060 & 10,3970 & 10,7186 & 33,3060 \\
3 & 10,2128 & 10,5286 & 43,8347 & 10,2128 & 10,5286 & 43,8347 & 10,2128 & 10,5286 & 43,8347 \\
4 & 7,8009 & 8,0422 & 51,8768 & 7,8009 & 8,0422 & 51,8768 & 7,8009 & 8,0422 & 51,8768 \\
5 & 5,6386 & 5,8130 & 57,6898 & 5,6386 & 5,8130 & 57,6898 & 5,6386 & 5,8130 & 57,6898 \\
6 & 5,1286 & 5,2872 & 62,9770 & 5,1286 & 5,2872 & 62,9770 & 5,1286 & 5,2872 & 62,9770 \\
7 & 4,3051 & 4,4382 & 67,4153 & 4,3051 & 4,4382 & 67,4153 & 4,3051 & 4,4382 & 67,4153 \\
8 & 3,9435 & 4,0655 & 71,4808 & 3,9435 & 4,0655 & 71,4808 & 3,9435 & 4,0655 & 71,4808 \\
9 & 3,1312 & 3,2281 & 74,7088 & 3,1312 & 3,2281 & 74,7088 & 3,1312 & 3,2281 & 74,7088 \\
10 & 3,0741 & 3,1692 & 77,8780 & 3,0741 & 3,1692 & 77,8780 & 3,0741 & 3,1692 & 77,8780 \\
\hline
\end{tabular}

Extraction Method: Principal Component Analysis.

Tabela 13 - Fatores comuns: Beta do Grau de Alavancagem Financeira 


\begin{tabular}{|c|c|c|c|c|c|c|c|c|c|}
\hline \multicolumn{10}{|c|}{ Total Variance Explained } \\
\hline \multicolumn{10}{|c|}{ GAF } \\
\hline \multirow[t]{2}{*}{ Component } & \multicolumn{3}{|c|}{ Initial Eigenvalues } & \multicolumn{3}{|c|}{$\begin{array}{l}\text { Extraction Sums of } \\
\text { Squared Loadings }\end{array}$} & \multicolumn{3}{|c|}{$\begin{array}{l}\text { Rotation Sums of } \\
\text { Squared Loadings }\end{array}$} \\
\hline & Total & $\begin{array}{c}\text { \%of } \\
\text { Variance }\end{array}$ & $\begin{array}{c}\text { Cumulative } \\
\%\end{array}$ & Total & $\begin{array}{c}\text { \%of } \\
\text { Variance }\end{array}$ & $\begin{array}{c}\text { Cumulative } \\
\%\end{array}$ & Total & $\begin{array}{c}\text { \%of } \\
\text { Variance }\end{array}$ & $\begin{array}{c}\text { Cumulative } \\
\%\end{array}$ \\
\hline 1 & 57,5101 & 59,2887 & 59,2887 & 57,5101 & 59,2887 & 59,2887 & 40,7717 & 42,0327 & 42,0327 \\
\hline 2 & 16,7784 & 17,2973 & 76,5860 & 16,7784 & 17,2973 & 76,5860 & 30,6684 & 31,6169 & 73,6496 \\
\hline 3 & 3,2947 & 3,3966 & 79,9827 & 3,2947 & 3,3966 & 79,9827 & 4,3801 & 4,5155 & 78,1651 \\
\hline 4 & 2,6029 & 2,6834 & 82,6661 & 2,6029 & 2,6834 & 82,6661 & 2,6496 & 2,7316 & 80,8967 \\
\hline 5 & 2,0603 & 2,1240 & 84,7901 & 2,0603 & 2,1240 & 84,7901 & 2,3232 & 2,3951 & 83,2918 \\
\hline 6 & 1,9136 & 1,9727 & 86,7629 & 1,9136 & 1,9727 & 86,7629 & 1,9734 & 2,0344 & 85,3262 \\
\hline 7 & 1,6300 & 1,6804 & 88,4433 & 1,6300 & 1,6804 & 88,4433 & 1,9366 & 1,9965 & 87,3227 \\
\hline 8 & 1,4895 & 1,5356 & 89,9788 & 1,4895 & 1,5356 & 89,9788 & 1,7491 & 1,8031 & 89,1259 \\
\hline 9 & 1,4629 & 1,5082 & 91,4870 & 1,4629 & 1,5082 & 91,4870 & 1,7392 & 1,7930 & 90,9189 \\
\hline 10 & 1,0845 & 1,1181 & 92,6051 & 1,0845 & 1,1181 & 92,6051 & 1,6356 & 1,6862 & 92,6051 \\
\hline
\end{tabular}

A Análise de Componentes Principais do Beta de Mercado extraiu 5 componentes comuns que explicaram até $94,47 \%$ da variação, sendo que o primeiro fator explica até $68,38 \%$ da variação. Esses resultados corroboram o próprio conceito do beta e extraem o fator comum, no caso o retorno médio das ações, o componente sistêmico do risco sistemático: o beta de mercado. A Análise de Componentes Principais do CMBT - Beta Contábil da Variação Percentual de Market to book extraiu 9 fatores comuns que explicam até 92,90\% da variação; o primeiro fator explica 68,13\%. O LAIRAT, Beta do Lucro Antes do Imposto de Renda sobre o Ativo Total, extraiu 9 fatores e os cinco primeiros explicam a 86,69\% da variação. Também para a variável GAF, Beta contábil do grau de Alavancagem Financeira, foram encontrados 10 fatores, sendo que os cinco primeiros esclarecem 83,29\% da variação. Estes resultados sugerem que existe, para as empresas analisadas, um componente comum presente nos betas da maioria das empresas analisadas.

Os betas de Grau de Alavancagem Operacional, beta do total de Capital de Terceiros sobre o PL e o beta do Índice de liquidez não apresentaram concentração do poder de explicação em alguns fatores como ocorre nos betas mencionados anteriormente. Este fato indica que, apesar de haver componentes comuns, não há entre as empresas analisadas um componente comum para o beta que possa ser encontrado na maioria delas. 
Dessa forma, a hipótese $\mathbf{H}_{0,5}$, que afirmava que "Os betas contábeis e betas de mercado possuem componentes comuns", não pôde ser aceita, pois não foram encontrados fatores comuns entre as empresas para todos os betas.

A última hipótese foi $\mathbf{H}_{0,6}$ : Os componentes comuns podem ser correlacionados canonicamente.

$\mathrm{Na}$ análise de Correlação Canônica, foram utilizados os dados dos escores produzidos pela análise fatorial. Para tanto, foram correlacionados os cinco primeiros fatores do beta de mercado com os cinco primeiros fatores de cada um dos betas contábeis. Os betas contábeis selecionados foram aqueles que apresentaram um poder de explicação acumulado, de pelo menos $80 \%$, para os cinco primeiros fatores. Devido a isto os betas contábeis selecionados foram: o beta da variação percentual de Market to book, o beta do Lucro Antes do Imposto de Renda sobre o Ativo Total e o beta do Grau de Alavancagem Financeira. A seguir, o resultado das Análises de Correlação Canônicas:

Tabela 14 - Canonical correlations: beta de mercado e \%MTB

\begin{tabular}{l|c|c|r|r|c}
\hline 5 & $\begin{array}{c}\text { Correlação } \\
\text { Canônica }\end{array}$ & Wilk's & Chi-SQ & DF & Sig. \\
\hline 1 & 0,997 & 0,003 & 290,495 & 25 & - \\
2 & 0,52 & 0,596 & 26,162 & 16 & 0,05 \\
3 & 0,397 & 0,816 & 10,27 & 9 & 0,24 \\
4 & 0,17 & 0,969 & 1,609 & 4 & 0,81 \\
5 & 0,051 & 0,997 & 0,133 & 1 & 0,72 \\
\hline
\end{tabular}

Tabela 19 - Canonical correlations: beta de mercado e LAIRAT

\begin{tabular}{l|c|r|r|r|c}
\hline 6 & $\begin{array}{c}\text { Correlação } \\
\text { Canônica }\end{array}$ & Wilk's & Chi-SQ & DF & Sig. \\
\hline 1 & 0,663 & 0,289 & 62,679 & 25 & - \\
2 & 0,526 & 0,516 & 33,436 & 16 & 0,06 \\
3 & 0,448 & 0,754 & 14,226 & 9 & 0,115 \\
4 & 0,205 & 0,944 & 2,933 & 4 & 0,57 \\
5 & 0,123 & 0,985 & 0,770 & 1 & 0,38 \\
\hline
\end{tabular}

Tabela 150 - Canonical correlations: beta de mercado e GAF

\begin{tabular}{l|c|c|r|r|c}
\hline 7 & $\begin{array}{c}\text { Correlação } \\
\text { Canônica }\end{array}$ & Wilk's & Chi-SQ & DF & Sig. \\
\hline 1 & 0,769 & 0,291 & 62,295 & 25 & - \\
2 & 0,413 & 0,712 & 17,188 & 16 & 0,374 \\
3 & 0,313 & 0,857 & 7,765 & 9 & 0,558 \\
4 & 0,193 & 0,951 & 2,551 & 4 & 0,636 \\
5 & 0,112 & 0,988 & 0,633 & 1 & 0,427 \\
\hline
\end{tabular}


A correlação canônica mede a força da associação entre os dois conjuntos de variáveis. A força do relacionamento entre os pares de variáveis é refletida, principalmente, pelos coeficientes canônicos da primeira função.

Primeiramente foi observado a significância da correlação canônica, considerando a validação do teste de Wilk. Foi constatado, para as três correlações canônicas, a significância estatística da primeira equação sugeridas no resultado.

Feito isso, o próximo passo foi analisar a medida de redundância da correlação canônica que indica quanto da variância nas variáveis dependentes são geradas pela variância das variáveis independentes. A medida de redundância é gerada elevando ao quadrado os coeficientes canônicos.Quando elevados ao quadrado, tais coeficientes representam a quantidade de variância em um composto linear da função canônica atribuída a outro composto da mesma função. Sendo assim, pode-se dizer que $(99,7 \%)^{2}$, ou seja, $99,4 \%$ da variação do beta de mercado são influenciados pela variação do beta de percentual de variação do Market to book. A elevada medida de redundância do beta de percentual de variação do Market to book pode ser explicada pelo fato de este, assim como o beta de mercado contero preço das ações em sua formulação.Foram verificados os coeficientes canônicos que apresentaram todos $<1,00$, o que refutaria a hipótese de regressão espúria.

A correlação canônica entre os cinco primeiros fatores comuns do beta de mercado e os cinco primeiros fatores do beta do Lucro Antes do Imposto de Renda sobre o Ativo Total apontou uma medida de redundância de $43,9 \%$. Isto significa que os fatores do beta do Lucro Antes do Imposto de Renda sobre o Ativo Total influenciam 43,9\% os fatores do beta de mercado.

Já a redundância do s fatores do beta do Grau de Alavancagem Financeira foi de 59,2\%. Este resultado indica uma possível maior influencia do Grau de Alavancagem financeira do que do retorno medido pelo Lucro Antes do Imposto de Renda sobre o Ativo Total.

Devido aos resultados, hipótese $\mathbf{H}_{\mathbf{0 , 6}}$ : Os componentes comuns são correlacionados canonicamente se faz verdadeira para apenas para 3 betas estudados. Desta forma, não é possível aceitar a hipótese $\mathbf{H}_{\mathbf{0 , 6}}$. 
Os resultados dão pistas de que os fatores dos betas contábeis e os fatores dos betas de mercado possuem relação, podendo o beta contábil cooperar na estimação do risco de uma empresa. Além disso, o resultado dá margem para especulações semelhantes às de Ball et al. (2009) e Connor e Korajczyk (1987) de que os fatores dos betas contábeis e de mercado são influenciados pelos mesmos elementos e podem ser os mesmos.

Em comparação com outros estudos, este trabalho vai ao encontro de Costa (2007), Ecker et al. (2009) e Rodrigues et al. (2008) que apontam um beta contábil como possível Proxy e substituto do beta de mercado. 


\section{CONCLUSÕES E CONSIDERAÇÕES FINAIS}

A hipótese de mercado eficiente e o CAPM trouxeram o conceito de que a nova informação relevante exerce um efeito imediato sobre o preço de um título, seja alterando expectativas a respeito de seu retorno, seja alterando expectativas quanto ao seu risco: beta de mercado. (HENDRIKSEN; VAN BREDA, 1999, p. 184). Ao encontro a essa realidade, este trabalho foi desenvolvido para investigar se os betas contábeis de uma empresa possuem relação com seu risco sistemático, calculado por meio do beta de mercado e se os betas contábeis e betas de mercado possuem os mesmos componentes, podendo o beta contábil cooperar na estimação do risco de uma empresa.

A revisão teórica do capítulo 2 apresentou a plataforma teórica em que repousa esta tese. Nela foram apresentados os conceitos de Hipótese de Mercado Eficiente e Information Approach (abordagem da informação), no qual a contabilidade é considerada como um meio de transmissão de informação. Também foram explanados: a Teoria de Portfólio; os conceitos de Risco; CAPM e o Risco sistemático calculado mediante o beta de mercado. Essas teorias fundamentam a relação entre o beta de mercado e os betas contábeis.

No capítulo 3, foram apresentados os estudos feitos sobre a relação entre a informação contábil e o mercado de capitais no exterior e no Brasil. Tais estudos indicam a existência de alguma relação entre variáveis contábeis e o preço da ação, sendo a variável contábil relevante para investidores de mercado de capitais e o mercado eficiente com respeito à informação contábil. (LOPES, 2002). Da mesma forma, foram enfocados os estudos existentes que investigaram a relação entre variáveis contábeis e risco no Brasil e no exterior. Essa revisão dá margem para a percepção de que há uma relação entre eles, porém não é descrita de forma conclusiva na literatura encontrada. A revisão da literatura, no exterior, assinalou que pesquisas sobre a associação entre variáveis contábeis e risco sistemático apontam para a existência de certa associação. No Brasil, somente alguns dos estudos levantados assinalaram uma relação positiva entre a variação dos resultados e o risco sistemático das empresas. Além disso, essas associações, em comparação a estudos feitos em outros mercados, apresentaram níveis de coeficientes de correlação menores. 
Com o intuito de estudar a relação entre a informação contábil e o risco sistemático, este estudo utilizou as proxies de betas contábeis e betas de mercado. Para tanto, propôs-se verificar: se existe relação entre o beta contábil de uma empresa e o beta de mercado de suas ações; se o beta contábil de uma empresa explica o beta de mercado de suas ações; se o beta contábil de uma empresa pode antecipar o beta de mercado de suas ações; se o beta contábil de uma empresa pode melhorar a previsão do beta de mercado de suas ações. Também, esta tese buscou entender se os betas contábeis e betas de mercado possuem componentes comuns e se esses são correlacionados canonicamente, isto é, são os semelhantes.

Para a realização do estudo foram selecionadas 97 empresas de 15 setores econômicos, entre o período $1^{\circ}$ - trimestre de 1995 e 3 - trimestre de 2009. Para os betas de mercado foram utilizados 6 diferentes tipos de cálculo. Para as variáveis de betas contábeis foram escolhidas 15 variáveis, sendo que algumas delas, ainda, não haviam sido utilizadas em estudos no Brasil, como Capital de Giro e o múltiplo Market to Book. Para cada uma das 15 variáveis, estipularam-se 36 versões, calculando-as sob as formas de betas contábeis, média e desviopadrão, cada uma dessas ainda em sua forma nominal, primeira diferença, variação percentual, padronizada por Ativo Total, Patrimônio Líquido ou Valor de Mercado.

Para testar saber se existia relação entre o beta contábil de uma empresa e o beta de mercado de suas ações, aplicou-se a ferramenta estatística de Correlação de Pearson para 6 betas de mercado com relação a 468 variáveis independentes, totalizando 2.808 coeficientes de correlação. Os resultados gerados na amostra para a maior parte das versões de betas contábeis foram poucos significativos ou mesmo inexistentes em grande parte das relações analisadas. Entretanto, para uma parte menor de betas contábeis, os resultados da correlação apontaram que, mesmo apesar dos coeficientes de correlação não serem elevados, ao redor de $30 \%$, não se pode negar que existe, em algum grau, uma associação entre os betas e as variáveis contábeis com os betas de mercado.

O segundo passo foi selecionar as variáveis que obtiveram uma maior correlação com betas de mercado e analisar se essas poderiam explicar, antecipar e melhorar a previsão do beta de mercado por intermédio da análise de dados em painel.

Os resultados indicaram vários Betas Contábeis como variáveis explicativas do beta de mercado, são eles: Variação Percentual do indicador Market to book; Total de capital de 
terceiros sobre o Patrimônio Líquido; Lucro Antes do Imposto de Renda sobre o Ativo Total; Grau de Alavancagem Operacional; Grau de Alavancagem Financeira; e o beta contábil do Indicador financeiro de Liquidez. Os resultados mostraram um poder de explicação da variável de $27 \%\left(\mathrm{R}^{2}\right.$ de 0,27$)$ e que o beta contábil de uma empresa explica o beta de mercado de suas ações. E para estes betas foi também realizado o teste de cointegração, o qual apontou que as variáveis podem possuir uma relação de longo prazo. Entretanto, para a maioria dos betas analisados não foi possível averiguar esta relação.

Os resultados também encontraram que alguns betas contábeis podem explicar, de forma antecipada, o beta de mercado das ações das empresas. Isso significa que até $14 \%\left(R^{2}\right.$ de 0,14$)$ do beta de mercado futuro pode ser explicado pelos betas contábeis de atuais. Dentre os betas contábeis que podem explicar, antecipadamente, valores em betas de mercado estão: Beta contábil do crescimento percentual do indicador Market to book, o Beta contábil do total de capital de terceiros (Passivo Circulante + Exigível a longo prazo), o Beta contábil do Lucro por Ação e o Beta contábil da Dívida onerosa.

Ainda foi notado que os betas contábeis melhoram a previsão do beta de mercado. Primeiramente, foi observado o poder de explicação do beta de mercado regredido a seus próprios dados históricos defasados em 1 período e, posteriormente, foi adicionado a essa equação os betas contábeis. Nas empresas estudadas, o poder de explicação passou de $33 \%$ $\left(\mathrm{R}^{2}\right.$ de 0,33$)$ para $40 \%\left(\mathrm{R}^{2}\right.$ de 0,40$)$ com a inclusão dos betas contábeis do Lucro Antes do Imposto de Renda sobre o Ativo Total, liquidez e market to book.

Os resultados da verificação das hipóteses de $\mathbf{H}_{\mathbf{0 , 1}, \mathbf{1}}, \mathbf{H}_{\mathbf{0 , 2},}, \mathbf{H}_{\mathbf{0 , 3}}$ e $\mathbf{H}_{\mathbf{0 , 4}}$ estão de acordo com estudos anteriores feitos no exterior que não encontraram relação significativa ou encontraram baixos $\mathrm{R}^{2}$ ou, ainda, encontraram grande parte dos coeficientes estatisticamente não diferentes de zero como os de Breen e Lerner (1973), Elgers (1980), Gonedes (1973), Lev (1974), StPierre e Bahri (2006).

No Brasil, estudos como os de Cupertino e Ogliari (2002), Gusmão e Cherobim (2009), Mendonça Neto e Bruni (2004), Minardi et al. (2007), Munhoz (2006) e Ribeiro Neto e Famá (2001) que não apresentaram relação entre as variáveis contábeis e betas contábeis, como o beta ROA, ou que apresentaram resultados não significativos que também foram corroborados por este trabalho. 
Em outra ponta, somente os betas contábeis Variação Percentual do indicador Market to book; Total de capital de terceiros sobre o Patrimônio Líquido; Lucro Antes do Imposto de Renda sobre o Ativo Total; Grau de Alavancagem Operacional; Grau de Alavancagem Financeira; e o beta contábil do Indicador financeiro de Liquidez apresentam uma relação com o beta de mercado e possui poder de explicação desse último. Esse resultado confirma o encontrado por Ball et al. (1993), Ball e Brown (1969), Beaver et al. (1970), Beaver e Manegold (1975), Bildersee (1975), Bowman (1979), Brimble e Hodgson (2007), Dechow (1994), Hill e Stone (1980), Ilha et al. (2009), Mandelker e Rhee (1984), Nekrasov e Shroff (2009), Rosenberg e Mckibben (1973), Pettit e Westerfield (1972), Teixeira e Valle (2008) e Thompson (1976).

Feito isso, esta tese procurou verificar se os betas contábeis e betas de mercado possuem componentes correlacionados, podendo o beta contábil cooperar na estimação do risco de uma empresa. Essa relação foi estudada somente com os betas contábeis apontados pela Análise de Dados em painel como possíveis explicativos do beta de mercado.

Para tanto, foi primeiro aplicado, para cada beta, a Análise de Componentes Principais por meio da técnica $S$-mode factor analysis para extrair as variações comuns entre as empresas analisadas. Os resultados expuseram que todos os betas contábeis e de mercado possuíam fatores comuns e três betas (Market to book; Lucro Antes do Imposto de Renda sobre o Ativo Total; e Grau de Alavancagem Financeira) apresentaram concentração dos fatores acima de $80 \%$ dos valores dos betas, em cada empresa, eram comum a todas as outras.

Somado a isso, utilizou a correlação canônica para entender o poder de explicação e a semelhança dos fatores dos betas contábeis com os fatores de betas de mercado. A correlação canônica, como explicado no capítulo 4, determina uma combinação linear para cada grupo de variáveis (dependentes e independentes) que maximize a correlação entre os dois grupos.

Para a mostra de empresas analisadas, o resultado indicou uma correlação, entre os cinco primeiros fatores do beta de mercado e de determinados betas contábeis. Os resultados apontaram que os 5 fatores comuns dos betas contábeis, são influenciados pelos c5 primeiros fatores dos betas de Market to book; Lucro Antes do Imposto de Renda sobre o Ativo Total; e Grau de Alavancagem Financeira. 
Esse resultado dá pistas de que esses fatores se assemelham ou são influenciados pelos mesmos elementos externos. Em comparação com outros estudos, este trabalho apoia Costa (2007), Ecker et al. (2009) e Rodrigues et al. (2008) que apontam um beta contábil como possível Proxy e substituto do beta de mercado. Entretanto para a grande maioria dos betas contábeis observados não pode ser constatada nenhuma relação com os betas de mercado.

Além da contribuição para a ampliação e o aprimoramento do conhecimento sobre a relação entre variáveis contábeis e o preço da ação, este trabalho incluiu a intenção de saber, especificamente, se os betas contábeis podem apresentar relações significativas com o beta de mercado, no mercado de capitais brasileiro. Igualmente, o trabalho, também, tentou inovar ao estudar a composição dos betas contábeis e betas de mercado e a existência de fatores comuns entre eles, ao invés de se aplicarem técnicas mais comumente utilizadas como somente a Correlação e a Análise de Regressão Múltiplas.

As implicações de se saber se um beta contábil e um beta de mercado possuem uma relação significativa, expõem se as informações contábeis são importantes para o mercado e possuem, assim, conteúdo informacional. Este estudo colabora com aqueles que unem as informações contábeis ao risco das empresas, incentivando pesquisas dessa relação.

Esta tese pretendeu cooperar com o mercado de capitais brasileiro, tentando contribuir com as pesquisas sobre cálculos de risco, adicionando conhecimento sobre: sugestão de novos cálculos para o beta de uma empresa; desenvolvimento de medidas mais eficientes ex post de risco; redução do foco do cálculo de risco somente para dados passados de retorno das ações; e melhorias para o desenvolvimento de estratégias para a construção de riscos de portfólios e modelos preditivos de risco conjuntural.

Buscou contribuir com o processo de avaliação de ativos, pois se a relação entre os betas contábeis e os betas de mercado é baixa, então, o modelo de avaliação que utiliza esses números contábeis não terá nível de significância considerável e não irá capturar a informação realmente ocorrida no mercado, tendo baixa exatidão. É importante para normatizadores de regulação contábil, pois procurou colaborar com o entendimento de quais variáveis podem ser mais associadas com o risco da empresa e o impacto de uma mudança ou inclusão de norma. Por fim, adiciona conhecimento ao investidor, sobre quais variáveis são as que mais se associam ao beta de mercado e ao risco da empresa. 
Embora o trabalho tenha identificado a existência de relação de significância estatística entre betas de mercado e determinados betas contábeis, não a encontrou para a maioria dos betas contábeis estudados. O tema permanece aberto a novos estudos e, ainda, requer aperfeiçoamentos que possam permitir testes mais rigorosos e aplicações práticas. É importante ressaltar que pesquisas futuras sobre este tema podem ser desenvolvidas para aprimorar o estudo em questão. Se melhor compreendida, essa relação apresenta potencial não apenas para melhorar o processo decisório nas áreas contábeis e financeiras das empresas, mas também para permitir uma avaliação mais precisa do risco das empresas. Assim, acreditase que o tema é de alta importância e merece novos desdobramentos. Espera-se que este trabalho tenha contribuído para aumentar o conhecimento acerca das relações entre as decisões de finanças corporativas e seus reflexos nos mercados de capitais.

Dentre as sugestões, novas pesquisas podem ser realizadas com o objetivo de identificar outras metodologias que proporcionem maior eficácia na mensuração do parâmetro de risco por meio da utilização de dados contábeis. Também, são necessárias pesquisas que detalhem mais os betas de mercado e os betas contábeis utilizados e que analisem essa relação em amostras diferenciadas como empresas reguladas, empresas que emitem ADR ou que possuem níveis de Governança Corporativa. Ainda, seriam importantes pesquisas que estudassem possíveis variáveis externas, como PIB, nível de atividade ou dados setoriais como explicativas para os fatores de betas de mercado e de betas contábeis, ou mesmo, pesquisas que observem essa relação em diferentes tipos de regulamentação contábil ou aspectos institucionais.

Com o presente estudo, sobre a relação entre a informação contábil e o risco sistemático, analisada pelas proxies de betas contábeis e betas de mercado, espera-se contribuir para o conhecimento em Contabilidade e que possa servir como referência para estudos posteriores num futuro próximo. A literatura existente sobre o tema indica a necessidade de que um maior número de pesquisas aprofunde o assunto e um maior número de empresas brasileiras sejam contempladas.

É importante constatar que os resultados gerados na amostra, sobre a relação entre betas contábeis e betas de mercado, mostraram que, para a maioria das versões de betas contábeis, foram poucos significativos ou mesmo inexistentes em grande parte das relações analisadas. 
Em última instância, os resultados obtidos mostraram a possibilidade de determinados betas contábeis poderem explicar o beta de mercado, para um número restrito de empresas da amostra e de determinados betas contábeis possuírem, em sua composição, partes semelhantes aos betas de mercado. 



\section{REFERÊNCIAS}

AGUIAR, A. B.; COELHO, A. C. D. Relacionamento entre persistência do lucro residual, poder de mercado e participação de mercado em firmas brasileiras. In: ENCONTRO DA ASSOCIAÇÃO DOS PROGRAMAS DE PÓS-GRADUAÇÃO EM ADMINISTRAÇÃO, 32., Rio de Janeiro. Anais... Rio de Janeiro: ANPAD, 2008.

ALFORD, Andrew et al. The relative informativeness of accounting disclosures in different countries. Journal of Accounting Research, v. 31, p. 183-223, 1993.

ALI, Ashiq; HWANG, Lee-Seok. Country-specific factors related to financial reporting and the value relevance of accounting data. Journal of Accounting Research, v. 38, n. 1, p. 1-21, 2000 .

ALMISHER, Mohamad A.; KISH Richard J. Accounting Betas - an ex anti proxy for risk within the IPO Market. Journal of Financial and Strategic Decisions, v.13, n.3, outono, 2000 .

AMARAL, H. F. La dynamique et l'efficience des marhes financiers brésiliens. Dissertação (Diplôme D'Etudes Approfondies en Sciences de Geston) - Institut D’Administration des entreprises. Toulouse: Université des Sciences Sociales de Toulouse I, 1990.

AMIR, Eli et al. A comparison of the value-relevance of U.S. versus non-US: GAAP accounting measures using form 20-f reconciliation. Journal of Accounting Research, v. 31. p. 203-264, 1993.

ANDESON, R. D. et al. Estatística aplicada à administração e economia. 2. ed. São Paulo: Pioneira Thompson Learning, 2003.

ASSAF NETO, A. Finanças corporativas e valor. São Paulo: Atlas, 2005.

BAESSO, Robson de Souza et al. Teste da hipótese de eficiência do mercado no Brasil: uma aplicação de filtros ótimos. In: ENCONTRO DA ASSOCIAÇÃO DOS PROGRAMAS DE PÓS-GRADUAÇÃO EM ADMINISTRAÇÃO, 32., Rio de Janeiro. Anais... Reio de Janeiro: ANPAD, 2008.

BALL, R.; BROW, P. An empirical evaluation of accounting numbers. Journal of Accounting Research, v. 7, Autumn 1968.

300-323, 1969.

Portfolio Theory and Accounting Theory. Journal of Accounting Research, 7, p.

et al. Economic determinants of the relation between earnings changes and stock

returns. The Accounting Review, n. 68, p. 622-638, 1993.

2009.

et al. Aggregate Earnings and Asset Price. Journal. The Accounting Review, March, 
BARTH, Mary; CLINCH, Greg. International accounting differences and their relation to share prices: evidence from U.K., australian, and canadian firms. Contemporary Accounting Research, v. 13, n. 1, p. 135-170, Spring, 1996.

et al. The relevance of the value relevance literature for financial accounting standard setting: another view. Journal of Accounting and Economics, v. 31, p. 77-104, 1993.

BEAVER, W. H. The information content of annual earnings announcements. Journal of Accounting Research, v.6, suplemento, 1968.

et al. The association between market determined and accounting determined risk measures. The Accounting Review, v. 45, p.654-682, 1970.

et al. The Association between unsystematic security returns and the magnitude of earnings. Forecast errors. Journal of Accounting Research, 17, p. 316-340, Autumn, 1979.

et al. The information content of security prices. Journal of Accounting and Economics. 2, p. 3-28, 1980.

; MANEGOLD, J. The association between market-determined and accountingdetermined measures of systematic risk: some further evidence. Journal of Financial and Quantitative Analysis, June, 1975. hall, 1998.

Financial reporting: an accounting revolution. 2nd ed. Englewood Cliffs.: Prentice

BERGMANN, D. R. et al. Testando o CAPM no mercado de capitais brasileiro via GMM. Revista de Economia e Administração, v. 6, p. 326-346, 2008.

BERNARD, V. L.; STOBER, T. L. The Nature and Amount of Information in Cash Flows and Accruals. The Accounting Review, p. 624-652, 1989.

BILDERSEE, John S. The association between a market-determined measure of risk and alternative measures of risk. Accounting Review, v. 50, issue 1, p. 81-98, January, 1975.

BLACK, F. Capital market equilibrium with restricted borrowing. Journal of Business, v. 45, p.444-455, July, 1972.

BOWMAN, G. The theoretical relationship between systematic risk and financial (accounting) variables. Journal of Finance, 34, p. 617-630, 1979.

BREALEY, R. A. et al. Fundamentos da administração financeira. 3a. ed. Rio de Janeiro: McGraw-Hill, 2002.

; MYERS, Stewart C. Principles of corporate finance. $7^{\text {th }}$ International ed. New York: McGraw-Hill, 2003.

BREEN, William J.; LERNER, Eugene M. Corporate financial strategies and market measures of risk and return. Journal of Finance, vol. 28, issue 2, p. 339-351. May, 1973. 
BRIMBLE, M.; HODGSON, A. Assessing the risk relevance of accounting variables in diverse economic conditions. Managerial Finance, v. 33, n. 8, p. 553-573, Emerald Group Publishing Limited 0307-4358, 2007.

BROWN, L. D. Influential accounting articles, individuals, Ph.D. granting institutions and faculties: a citational analysis. Accounting Organizations and Society, 21 (7/8), p. 723- 754, 1996.

BROWN, Philip; KENNELLY, John W. The Information Content of Quarterly Earnings: An Extension and Some Further Evidence. The Journal of Business, v. 45, p. 403-415, july 1972.

BUFFET, W. Berkshire hathaway annual report, 1992.

CALDEIRA, L. M. et al. A eficiência de mercado na América Latina: um estudo da hipótese de caminho aleatório no Brasil, México, Peru e Argentina. In: Congresso de Controladoria e Contabilidade. 2004

CAMARGOS, M. A.; BARBOSA, F. V. Teoria e evidência da eficiência informacional do mercado de capitais brasileiro. Caderno de Pesquisas em Administração, São Paulo, v. 10, n. 1, p. 43-55 2003.

CAMPBELL, J. L. et al. The econometrics of FinanciaL Markets. Princeton University Press, Princeton, NJ, 1997.

CAMPBELL, John Y.; SHILLER, Robert J. The dividend-price ratio and expectations of future dividends and discount factors. Review of Financial Studies, 1, p. 195-227. 1988a.

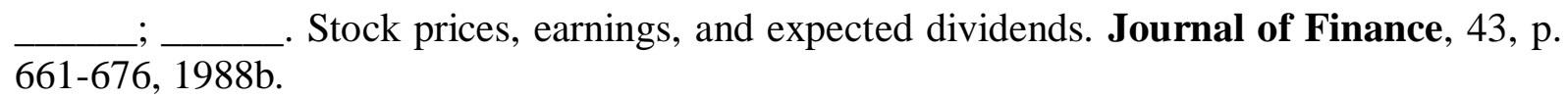

CAMPBELL, John Y. A variance decomposition for stock returns. Economic Journal, 101, p. 157-179. 1991.

CARDOSO, D.; AMARAL, H. F. Economic-financial analysis of the Brazil siderurgical sector: building a comparative system between the Belgo Mineira and the sectorial indicators using the Fleuriet model. In: BUSINESS ASSOCIATION OF LATIN AMERICAN STUDIES, 2000, Venezuela. Anais... Venezuela: BALAS, 2000.

CARDOSO R. L.; MARTINS V. A. Hipótese de mercado eficiente e modelo de precificação de ativos financeiros. Teoria avançada da contabilidade. São Paulo: Atlas, 2004.

CASTAGNA, A.D.; MATOLCSY, Z.P. The relationship between accounting variables and systematic risk and the prediction of systematic risk. Australian Journal of Management, v. 3, p. 113-26, 1978.

CERBASI, G. P. Metodologias para determinação do valor das empresas: Uma aplicação no setor de geração de energia elétrica. 2003. Dissertação (Mestrado em Administração) Programa de Pós-Graduação em Administração, Departamento de Administração da Faculdade de Economia, Administração e Contabilidade da Universidade de São Paulo, São Paulo. 
CERETTA, P. S. Comportamento das variações de preços nos mercados de ações da América Latina. In: ENCONTRO NACIONAL DOS PROGRAMAS DE PÓS-GRADUAÇÃO EM ADMINISTRAÇÃO, 2001a, Campinas Anais... São Paulo, 2001a.

Hipótese do caminho aleatório nos mercados da América Latina: aplicação do teste de quociente de variância. 2001b. Tese (Doutorado em Engenharia de Produção), Universidade Federal de Santa Catarina.

; PERLIN, M. S. O CAPM na Bolsa de São Paulo: um modelo condicional. In: CONGRESSO DE CONTROLADORIA E CONTABILIDADE, 4., São Paulo. Anais ... São Paulo, 2004.

CERVO A. L.; BERVIAN P. A. Metodologia científica. 5 ed. São Paulo: Prentice, 2002.

CHAN, Kam C.; SEOW, Gim S. the association between stock returns and foreign GAAP earnings versus earnings adjusted to U.S. GAAP. Journal of Accounting and Economics, vol. 21, p. 139-158, 1996.

COLLINS, Daniel W., KOTHARI, S. P. An analysis of intertemporal and cross-sectional determinants of earnings response coe $\varnothing$ cients. Journal of Accounting and Economics, v. 11, p. 143-181, 1989.

et al. Changes in the value-relevance of earnings and book values over the past forty years. Journal of Accounting and Economics, v. 24, p. 39-68, December, 1997.

CONNOR, Gregory; KORAJCZYK, Robert A. Estimating pervasive economic factors with missing observations. Working paper \#34, Department of Finance, Northwestern University, 1987.

The Three Types of Factor Models: A Comparison of their Explanatory Power. Financial Analysts Journal, n. 51, p. 42-46, 1995.

CONTADOR, C. R. Uma análise espectral dos movimentos da Bolsa de Valores do Rio de Janeiro. Revista Brasileira de Mercado de Capitais. Rio de Janeiro: Instituto Brasileiro de Mercado de Capitais, v. 1, n. 1, jan.-abr./1975.

COPELAND, T.; WESTON, J. F. Financial theory and corporate policy. 3a. ed. Los Angeles: Addison-Wesley, 1992.

et al. Avaliação de empresas: valuation. 3. ed. Makron Books: São Paulo, 2002.

COROA, Utilan da Silva Ramos et al. Estratégias de investimentos: uma análise da diversificação internacional de portfolios e a integração dos mercados na América Latina. In: CONGRESSO USP DE CONTROLADORIA E CONTABILIDADE, 5., 2005, São Paulo. Anais... São Paulo, 2005.

et al. Anomalias em Mercados de Capitais: constatações empíricas no mercado de ações brasileiro no período de 1999 a 2003. In: CONGRESSO USP DE CONTROLADORIA E CONTABILIDADE, 4., 2004, São Paulo. Anais... São Paulo, 2004.

CORRAR, L. J. et al. Análise multivariada. São Paulo: Atlas, 2009. 
COSTA, J. S. Beta Contabilístico e risco sistemático associado a projetos de investimento de capital. ABCustos Associação Brasileira de Custos, v. 2, n. 2, maio-ago./ 2007.

COUTINHO, A. H. et al., Relevância contábil da marcação a mercado das instituições financeiras no Brasil. In: ENCONTRO NACIONAL DA ASSOCIAÇÃO NACIONAL DA PÓS-GRADUAÇÃO EM CIÊNCIAS CONTÁBEIS, 1., 2007, Gramado. Anais... Gramado: ANPCONT, 2007.

CUNHA, Moisés. F. da; LUSTOSA, P. R. B. Medidas de desempenho: um estudo sobre a importância do lucro contábil e do fluxo de caixa das operações no mercado de capitais brasileiro. In: ENCONTRO NACIONAL DA ASSOCIAÇÃO NACIONAL DOS PROGRAMAS DE PÓS-GRADUAÇÃO EM ADMINISTRAÇÃO 31., 2007, Rio de Janeiro. Anais... Rio de Janeiro: ANPAD, 2007.

CUPERTINO C. M. Fluxo de caixa, lucro contábil e dividendos: comparação de diferentes enfoques na avaliação de empresas brasileiras. In: CONGRESSO USP DE CONTROLADORIA E CONTABILIDADE, 2003, São Paulo. Anais... São Paulo: USP, 2003.

; OGLIARI, P. R. A correlação entre o retorno sobre o ativo e o beta das empresas brasileiras. Disponível em: <http//:investsul.com.br>. Acesso em: 15/10/2001.

DAMODARAN, A. Damodaran on valuation: security analysis for investment and corporate finance. New York: John Wiley \& Sons, 1994.

A avaliação de investimentos: ferramentas e técnicas para a determinação do valor de qualquer ativo - Rio de Janeiro: Qualitymark, 2005.

DECHOW, Patricia M. Accounting Earnings and Cash Flows as Measures. Working paper, 1994.

ECKER, F. et al. A comparison of market-based and accounting-based descriptions of business risk. Working Paper. Duke University, 2009.

EHRBAR, A. EVA, valor econômico agregado: a verdadeira chave para a criação de riqueza. Rio Janeiro: Qualitymark, 1999.

ELGERS, P. Accounting based risk predictions: a re-examination. The Accounting Review, n. 55, p.389-408, July, 1980.

ELGERS, Pieter; REES, Lynn. The market's valuation of non-reported accounting measures: retrospective reconciliations of non-U.S. and U.S. GAAP. Journal of Accounting Research, vol. 35, n. 1, p. 115-127, Spring 1997.

ESKEW, R. The forecasting ability or accounting risk measures: some addition nal evidence. The Accounting Review, v.54, p.107-118, 1979.

FAMA, E. F. Efficient capital markets: a review of theory and empirical work. Journal of Finance, v. 25, n. 2, p.3 83-417, 1970.

Efficient capital markets II. Journal of Finance, v. 66, n. 5, p. 1575-1617, 1991. 

80, 1995.

Random walks in stock market prices. Financial Analysts Journal, v. 51, n. 1, p. 75-

; FRENCH, K. R. Permanent and temporary components of stock prices. Journal of Political Economics, v. 96, n.2, p. 246-273, 1988.

; MACBETH, James D. Risk, return and equilibrium: empirical tests. Journal of Political Economy, p. 607-636, May-June, 1973.

; MILLER, Merton. The theory of finance. Illinois: Dryden, 1972.

FAMÁ, R. ; RIBEIRO NETO, R. M. . Beta Contabilístico - Uma aplicação no mercado financeiro brasileiro. In: SEMINÁRIOS EM ADMINISTRAÇÃO DA FEA/USP, 5. 2001, São Paulo. Anais... São Paulo: SEMEAD, 2001.

FARRELY, Gail E. et al. Perceived risk, market risk, and accounting determined risk measures. The Accounting Review, v.60, p.278- 288, Abr., 1985.

FINANCIAL ACCOUNTING STANDARD BOARD (FASB). Statement of Financial Accounting Concepts (SFAC) n. 1 - Objectives of Financial Reporting by Business Enterprises, 1978.

FELTHAM, G. A.; OHLSON , J. A. Valuation and Clean Surplus Accounting for Operating and Financial Activities. Contemporary Accounting Research, v. 11, p. 689-731, 1995.

FERNANDES, A. L. M. et al. Teste de aderência entre o beta contábil e o beta de mercado: uma aplicação prática no mercado brasileiro. In: CONGRESSO BRASILEIRO DE CONTABILIDADE, 18., 2008, Gramado. Anais... Gramado: CBC, 2008.

FERNANDES, A. S. Análise empírica dos fatores determinantes do risco sistemático nas empresas. 2007. Dissertação. (Mestrado) - Universidade Federal de Brasília, 2007.

FERNANDES, F. C. et al. Riscos e controles internos: uma metodologia de mensuração dos níveis de controle de riscos empresariais. Revista Contabilidade \& Finanças (Online), v. 43, p. 49-60, 2007.

FERNANDEZ, A. Teste de aderência entre os betas contábeis e de mercado: uma aplicação prática no mercado brasileiro. Dissertação. (Mestrado) - Fundação Instituto Capixaba de Pesquisas em Contabilidade, Economia e Finanças - FUCAPE.

FERREIRA, M. A. Uma análise empírica da relação ente o EVA (Economic Value Added) e o retorno das ações no mercado acionário brasileiro. 2006. Dissertação (Mestrado em Administração) - Curso de Pós-Graduação em Administração, Pontifícia Universidade Católica, Rio de Janeiro.

FISHER, Franklin M. Tests of equality between sets of coefficients in two linearregressions: an expository note. Econometrica, v. 38, p. 361-366, March, 1970.

FLEURIET, M. et al. A dinâmica financeira das empresas brasileiras: um novo método de análise, orçamento e planejamento financeiro. Belo Horizonte: Fundação Dom Cabral, 1978. 
FONSECA, Jairo S., MARTINS, Gilberto. A. Curso de estatística. 6. ed. São Paulo: Atlas, 1996.

FORTUNA, E. Mercado financeiro: produtos e serviços. 12. ed. Rio de Janeiro: Qualitymak, 1999.

FOSTER, G. Financial statement analysis. 2nd edition. Englewood Cliffs: Prentice Hall, 1986.

Quarterly accounting data: time-series properties and predictive-ability results. The Accounting Review, n. 52, p.1-21, 1977.

FRIEDMAN, M. The methodology of positive economics, essays in positive economics. Chigago: University of Chicago Press, 1953.

GARROD, Neil; MRAMOR, Dusan. On accounting flows and systematic risk. Working Paper n. 82, Faculty of Economics, University of Ljubljana. Presented at the 10th INQUIRE UK Anniversary Seminar, Institute for Quantitative Investment Research UK, 1998.

GITMAN, L. Princípios de administração financeira. 10. ed. São Paulo, 2003.

GOMES, A. G.; LORIATO, L. L. Volumes anormais de negócios no mercado brasileiro de ações em função dos anúncios anuais. In: CONGRESSO USP DE CONTROLADORIA E CONTABILIDADE, 2006. São Paulo. Anais... São Paulo: USP, 2006.

GONEDES, N. Evidence on the information content of accounting massages: accounting based and market-based estimate of systematic risk. Journal of Financial and Quantitative Analysis, v.8, p.407-444, 1973.

GUJARATI, D. N. Econometria básica. Tradução de Ernesto Yoshida. 3. ed. São Paulo: Pearson Mabron Boobs, 2006. 846 p.

GUSMÃO, I.; CHEROBIM, A. Estimando o risco de empresas emissoras de ADR: análise entre o beta de mercado versus o beta contábil. In: SEMINÁRIOS EM ADMINISTRAÇÃO DA FEA/USP, 5., 2001, São Paulo. Anais... São Paulo: SEMEAD, 2001.

Hair, J. F. Jr. et al. Análise multivariada de dados. Tradução da $5^{\mathrm{a}}$ edição americana por Adonai Schlup Sant'Anna e Anselmo Chaves Neto. Porto Alegre: Bookman, 2005.

HAMADA, R. The effect of the firm's capital structure on the systematic risk of common stocks. Journal of Finance, May, 1971.

HAYN, C. The information content of losses. Journal of Accounting and Economics, 20, p. 123-153, 1995.

HEALY, P. M.; PALEPU, K. G. Earnings Information Conveyed by Dividend Initiation and Omissions. Journal of Financial Economics, n. 21, p. 149-175, 1988.

HENDERSON et al. Financial accounting theory: its nature e develop. 2.ed. Cheshire: Longman, 1992. 
HENDRIKSEN, Eldon S.; VAN BREDA, Michael F. Accounting theory. 5. ed. USA: Irwing, 1992.

Teoria da contabilidade. Tradução Antonio Zorato Sanvicente. São Paulo: Atlas, 1999.

HICKMAN, W. Braddock. Corporate bond quality and investor experience. Princeton University Press for the National Bureau of Economic Research, 1958.

HILL, Ned C.; STONE, Bernell K. Accounting betas, systematic operating risk, and financial leverage: a risk-composition approach to the determinants of systematic risk. Journal of Financial and Quantitative Analysis, vol. 40, n. 3, p. 595-637, September, 1980.

HOLTHAUSEN, R.W.; WATTS, R. L. The relevance of the value-relevance literature for financial accounting standard setting. Journal of Accounting \& Economics, n. 31, p. 3-75, 2001.

ILHA, S. V. et al. Construção empírica e análise teórica do beta contábil: uma investigação no mercado acionário brasileiro sob a ótica de diferentes pressupostos econométricos. In: CONGRESSO USP DE CONTROLADORIA E CONTABILIDADE, 9., 2009, São Paulo. Anais... São Paulo: USP, 2009

ISMAIL, B.; KIM, M. On the association of cash flow variables with market risk: further evidence. Accounting Review, 64, 1989, p. 125-136.

IUDÍCIBUS, Sérgio de. Teoria da contabilidade. 6. ed. São Paulo: Atlas, 2000. 2004.

; LOPES, Alexsandro Broedel. Teoria avançada da contabilidade. São Paulo: Atlas,

JENSEN, M. Some anomalous evidence regarding market efficiency. Journal of Financial Economics, v. 6, n. 2/3, p. 95-101, 1978.

JHONSON, R. A.; WICHERN, D. W. Applied multivariate statistical analysis. 2 ed. New York: Prentice Hall, 1988.

JOHNSTON, Jack; DINARDO, John. Econometric methods. 4th edition. New York: McGraw-Hill, 1999.

JOOS, Peter; LANG, Mark. The effects of accounting diversity: evidence from the European Union. Journal of Accounting Research, v. 32, p. 141-168, 1994.

KARELS, G.V.; W. H. SACKLEY. The relationship between market and accounting betas for commercial banks. Review of Financial Economics, v.2, p.59-72, 1993.

KAWAKATSU, H.; MOREY, M. R. Financial liberalization and stock market efficiency: an empirical examination of nine emerging market countries. Journal of Multinational Financial Management, v.9, p. 353-371, 1999.

KERLINGER, Fred Nichols. Metodologia da pesquisa em ciências sociais: um tratamento conceitual. São Paulo: EPU-EDUSP, 1980. 
KIM, J.; MUELLER, C.W. Introduction to factor analysis: what is and how to do it. Bervely Hills: Sage Publications, 1978.

KORMENDI, R.; LIPE, R. Earnings inovation, earnings persistence, and stock returns. Journal of Business, v. 60, p. 323-345, 1987.

KOTHARI, S. Capital markets research in accounting. Journal of Accounting \& Economics, 31, p. 105-231, 2001.

LACEY et al., 2004. Estimativa do custo de capital próprio de pequenas empresas através do CAPM. Alcance, v. 11, n. 2, p. 227-237, Maio-Ago./2004.

LAVEREN, E. et al. Beta estimation and unlevering. Working Paper, Antwerpen, 1996.

et al. Can accounting variables explain any beta? Working Paper, UFSIA, Department of Business Economics, Antwerpen, 1997.

LEAL, R. P. C.; AMARAL, A. S. Um momento para o "insider trading": o período anterior ao anúncio de uma emissão pública de ações. Revista Brasileira do Mercado de Capitais. Rio de Janeiro: Instituto Brasileiro de Mercado de Capitais, v. 15, n. 41, p. 21-26, 1990.

LEV, Baruch; KUNITZKY, Sergius. On the association between smoothing measures and the risk of common stocks. Accounting Review, vol. 49, issue 2, p. 259-270, April, 1974.

On the association between operating leverage and risk. Journal of Financial and Quantitative Analysis, September/1974.

On the usefulness of earnings and earnings research: lessons and direction from two decades of empirical research. Journal of Accounting Research, 27, p. 153-201, 1989.

LIMA, Gerlando Auguto Sampaio Franco. Utilização da teoria de divulgação para a avaliação da relação do nível de disclousure das empresas brasileiras. 2007. Tese (Doutorado) - Programa de Pós-Graduação em Ciências Contábeis do Departamento de Contabilidade e Atuária. Faculdade de Economia Administração e Contabilidade da Universidade de São Paulo, São Paulo.

et al. Um estudo da eficiência informacional do mercado acionário brasileiro. Revista de Informação Contábil, v. 2, p. 1-18, 2008.

LIMA, J. B. N.; TERRA, P. R. S. A reação do mercado de capitais brasileiro à divulgação das informações contábeis. In: ENCONTRO ANNUAL DA ASSOCIAÇÃO DOS PROGRAMAS DE PÓS-GRADUAÇÃO EM ADMINISTRAÇÃO, 28., 2004. Curitiba. Anais... Curitiba: EnANPAD, 2004.

SANTANA, L.; LIMA, F. G. EBITDA: Uma análise de correlação com os retornos totais aos acionistas no mercado de capitais brasileiro. In: CONGRESSO USP CONTROLADORIA E CONTABILIDADE, 4., 2004. São Paulo. Anais... São Paulo: USP, 2004.

LINTNER, J. The valuation of risk assets and the selection of risk investmentes instock portfolios and capital budgets. Review of Economic and Statistics. v. 47, p. 13-37, Feb. 1965. 
LOPES, Alexsandro Broedel. A relevância da Informação Contábil para o Mercado de Capitais: o modelo de Ohlson aplicado à Bovespa.Tese de Doutorado na Universidade de São Paulo, Faculdade de Economia, Administração e Contabilidade. Departamento de Contabilidade e Atuaria. São Paulo 2001.

A informação contábil e o mercado de capitais. São Paulo: Pioneira Thompson Learning, 2002.

; MARTINS, Eliseu. Teoria da contabilidade: uma nova abordagem. São Paulo: Atlas, 2005.

; GALDI, Fernando Caio. Financial Statement Analysis also separate Winners from Losers in Brazil. In: SEMINÁRIO DE PESQUISA ECONOMICA DA EFGE/FGV, 2006. São Paulo. Anais... Realizado na USP. São Paulo, 2006.

LOUZADA, Luiz Cláudio et al. In: RESUMO DOS TRABALHOS DO EnANPAD, Rio de Janeiro: ANPAD, 2005.

LUSTOSA, P. R. B.; PEREIRA, C. C. Impacto das notícias pré-divulgadas no lucro: uma análise do setor de siderurgia e metalurgia brasileiro. In: CONGRESSO USP DE CONTABILIDADE, 7., 2007, São Paulo. Anais... São Paulo: USP, 2007.

MALACRIDA, M. J. C. et al. A relevância da demonstração do fluxo de caixa para o mercado de capitais brasileiro. In: ENCONTRO NACIONAL DA ASSOCIAÇÃO DOS PROGRAMAS DE PÓS-GRADUAÇÃO EM ADMINISTRAÇÃO, 32., Rio de Janeiro. Anais... Rio de Janeiro: ANPAD, 2008.

MANDELKER, Gershon N.; RHEE, S. Ghon. The impact of the degrees of operating and financial leverage on systematic risk of common stock. Journal of Financial and Quantitative Analysis, vol. 19, issue 1, p. 45-57, Mar./1984.

MALHOTRA, Naresh K. Pesquisa de marketing: uma orientação aplicada. Porto Alegre: Bookman, 2004.

MARCONI, M. A.; LAKATOS, E. M. Técnicas de pesquisa. São Paulo: Atlas, 2003.

MÁRIO, P. C.; AQUINO, A. C. B. Falências. In: Iudícibus, S. de; Lopes, A. B. Teoria avançada da contabilidade. São Paulo: Atlas, 2004.

MARKOWITZ, Harry. Portfolio selection. The journal of finance, v. 7, n. 1, p. 77-91, Mar./1952.

MARTELANC, R. et al. Avaliação de empresas: um guia para fusões e aquisições e gestão de valor. São Paulo: Financial Times / Prentice Hall, 2004.

MARTIN, J. D.; PETTY, J. W. Gestão baseada em valor: a resposta das empresas à revolução dos acionistas. Rio de Janeiro: Qualitymark, 2004.

MARTINEZ, A. L. Análise da surpresa dos analistas ao anúncio dos resultados contábeis: evidências empíricas para as companhias abertas brasileiras. In: CONGRESSO DE CONTABILIDADE E CONTROLADORIA DA USP, 4., 2004, São Paulo. Anais... São Paulo: USP, 2004. 
MARTINS, E. et al. Avaliação de empresas. In: MARTINS, E. (Org.). Avaliação de Empresas: da mensuração contábil à econômica. Capítulo 5, p. 263 a 308. São Paulo: Atlas, 2001.

MARTINS, G. A. Manual para elaboração de monografias e dissertações. 2. ed. São Paulo: Atlas, 1994.

MEEK, Gary K. U.S. securities market responses to alternative earnings disclosures of nonU.S. multinational corporations. The Accounting Review, vol. LVIII, n. 2, p. 394-402, April, 1983.

; THOMAS, Wayne B. A review of markets-based. Journal International Accounting Research, vol. 3, n. 1, p. 21-41, 2004.

MENDONÇA NETO, J.; BRUNI, A. L. Risco, retorno e equilíbrio: existe associação entre indicadores contábeis e os retornos das ações negociadas na Bovespa? Revista Gestão e Planejamento, ano 5, n. 10, p. 78-90, Salvador, jul.-dez./2004.

MINARDI, A. et al. Estimando o custo de capital de companhias fechadas no brasil para uma melhor gestão estratégica de projetos. IBMEC Working Paper. WPE-33, 2007.

MORSE, D. Price and Trading Volume Reaction Surrounding Earnings Announcements: A Closer Examination. Journal of Accounting Research, 19, p. 374-383, 1981.

MOSSIN, J. Equilibrium in a capital asset market. Econometrica, p. 768-783, Oct./ 1966.

MUELLER, Gerhard G. et al. Accounting: an international perspective. New York: Business One Irwin, 1994.

MUNHOZ, D. A utilização do lucro contábil como proxy de risco no Brasil. Dissertação. 2006. (Mestrado) - Faculdade de Economia, Administração, Contabilidade e Ciência da Informação e Documentação, Universidade de Brasília.

MUNIZ, C. J. Testes preliminares de eficiência do mercado de ações brasileiro. Revista Brasileirado Mercado de Capitais. Rio de Janeiro: Instituto Brasileiro de Mercado de Capitais, v. 6, n. 16, p. 80-94, jan.-abr./1980.

NAKAMURA, W. T. et al. Determinantes de estrutura de capital no mercado brasileiro: análise de regressão com painel de dados no período 1999-2003. Revista Contabilidade \& Financas, v. 18, p. 72-85, 2007.

NAKAMURA, W. T.; MATIAS FILHO, J. Estudo empírico sobre metodologias alternativas de aplicação do CAPM no mercado de ações brasileiro. In: CONGRESSO USP DE CONTROLADORIA E CONTABILIDADE, 6., 2006, São Paulo. Anais... São Paulo: USP, 2006.

NASCIMENTO, M. et al. Análise do conteúdo informacional do resultado contábil em USGAAP: um estudo de evento cm companhias abertas brasileiras que negociam ADRs na Bolsa de Nova Iorque. In: ENCONTRO NACIONAL DA ASSOCIAÇÃO DOS PROGRAMAS DE PÓS-GRADUAÇÃO EM ADMINISTRAÇÃO, 31., 2007. Rio de Janeiro. Anais... Rio de Janeiro: ANPAD, 2007. 
NEKRASOV, A., SHROFF, P. Fundamentals-Based Risk Measurement in Valuation. The Accounting Review American Accounting Association, v. 84, n. 6, p. 1983-2011, November, 2009.

NOSSA, V. et al. EBTIDA: uma análise de correlação com os retornos totais aos acionistas no mercado de capitais brasileiro. In: ENCONTRO NACIONAL DA ASSOCIAÇÃO DOS PROGRAMAS DE PÓS-GRADUAÇÃO EM ADMINISTRAÇÃO, 27., 2004. Curitiba. Anais... Curitiba: ANPAD, 2004.

ODA, A. Luiz et al. Análise da relação entre indicadores contábeis e betas de mercado das empresas brasileiras negociadas na bolsa de valores de São Paulo no período 1995 - 2003. In: ENCONTRO ANUAL DA ASSOCIAÇÃO NACIONAL DOS PROGRAMAS DE PÓSGRADUAÇÃO EM ADMINISTRAÇÃO, 28., 2004. Curitiba. Anais... Curitiba: ANPAD, 2004.

ODA, A. Luiz. Análise da relação entre indicadores contábeis e betas de mercado das empresas brasileiras negociadas na Bolsa de Valores de São Paulo no período 1995 - 2003. 2004. Tese (Doutorado em Administração) - Programa de Pós-Graduação em Administração, Faculdade de Economia, Administração e Contabilidade, Universidade de São Paulo, São Paulo.

OHLSON, J. A. Earnings, book values, and dividends in equity valuation. Contemporary Accounting Research, v. 11, p. 661-687, 1995.

OKIMURA, R. T.; SOUSA, Almir Ferreira de . O valor econômico adicionado possui maior relação com o retorno das ações do que o lucro líquido no Brasil? In: ENCONTRO ANUAL DA ASSOCIAÇÃO NACIONAL DOS PROGRAMAS DE PÓS-GRADUAÇÃO EM ADMINISTRAÇÃO, 28., 2004. Curitiba. Anais... Curitiba: ANPAD, 2004.

ORTOLAN, V. Uma investigação da reação dos retornos das ações as divulgações de resultados de empresas de capital aberto, no Brasil e no México. 2007. Dissertação. (Mestrado) - Faculdade de Economia Administração e Contabilidade da Universidade de São Paulo, Ribeirão Preto.

PASIN, R. M. Avaliação relativa de empresas por meio da Regressão de direcionadores de valor. 2004. Tese (Doutorado em Administração) - Programa de Pós-Graduação em Administração, Faculdade de Economia, Administração e Contabilidade, Universidade de São Paulo, São Paulo.

PEREIRO, Luis E. Valuation of companies in emerging markets: a practical approach. New York: John Wiley, 2002, 507 p.

PERLIN, M. S.; CERETTA, P. S. CAPM e o mercado brasileiro. In: CONGRESSO USP DE CONTROLADORIA E CONTABILIDADE, 4., 2004, São Paulo. Anais... São Paulo: FEA/USP, 2004. (CD-ROM).

PEROBELLI, F. F. C.; NESS Jr., W. Reações do mercado acionário a variações inesperadas nos lucros das empresas: um estudo sobre a eficiência informacional no mercado brasileiro. In: ENCONTRO ANUAL DA ASSOCIAÇÃO NACIONAL DOS PROGRAMAS DE PÓSGRADUAÇÃO EM ADMINISTRAÇÃO, 24, 2000. Campinas. Anais... Campinas: ANPAD, 2000. 
PETTIT, R. Richardson; WESTERFIELD, Randolph. A model of capital asset risk. Journal of Financial and Quantitative Analysis, vol. 7, issue 2, p. 1649-1668, March, 1972.

PINDYCK, R. S.; RUBINFELD, D. L. Microeconomia. São Paulo: Makron Books, 2002.

PIOTROSKI, Joseph D. Value investing: the use of historical financial statement information to separate winners from losers. Jornal of Accounting Research, v. 38, p.1 - 41, 2000.

. Discussion of "separating winners from losers among low book-tomarket stocks using financial statement analysis. Jornal of Accounting Research, v. 10, p.171 - 184, 2005.

POPE, Peter F.; RESS, William P. International differences in GAAP and the pricing of earnings. Journal of International Financial Management e Accounting, v. 4, n. 3, p. 190219, Autumn, 1992.

PRUX JR., Jaime Luiz. Assimetria informacional e precificação das ações das empresas negociadas na Bolsa de Valores de São Paulo: evidências a partir da faculdade de divulgar demonstrações contábeis em moeda constante a partir de 1996. 1998. Dissertação (Mestrado em Administração) - Faculdade de Ciências Econômicas da Universidade Federal do Rio Grande do Sul.

RAPPAPORT, A. Gerando valor para o acionista: um guia para administradores e investidores. São Paulo: Atlas, 2001.

; MAUBOUSSIN, M. J. Análise de investimento: como transformar incertezas em oportunidades lucrativas: como interpretar corretamente o preço das ações um guia para administradores e investidores. Rio de Janeiro: Campos, 2002.

REZENDE, A. J. et al. A relevância da informação contábil no mercado de ações brasileiro: uma análise informação societária e informação corrigida. In: ENCONTRO ANUAL DA ASSOCIAÇÃO NACIONAL DOS PROGRAMAS DE PÓS-GRADUAÇÃO EM ADMINISTRAÇÃO, 32., Rio de Janeiro. Anais... Rio de Janeiro: ANPAD, 2008.

RIBEIRO NETO, Ramon Martinez; FAMÁ, Rubens. Beta contabilístico - uma aplicação no mercado financeiro brasileiro. In: SEMINÁRIOS EM ADMINISTRAÇÃO 5., 2001, São Paulo. Anais... São Paulo: USP, 2001.

RICHARDSON, R. J. Pesquisa social: métodos e técnicas. São Paulo: Atlas, 1999.

ROBERTS, H. Statistical versus clinical prediction of the stock market. Paper in Center for Research in Security Prices. University of Chicago, May, 1967.

RODRIGUES, R. N. et al. Beta contábil vs. beta CAPM: uma investigação empírica no mercado financeiro brasileiro. Revista de Contabilidade da UFBA, v. 2, p. 4, 2008.

ROMER, D. Advanced macroeconomics. 2. ed. McGraw Hill, 2001.

ROSENBERG, B.; McKIBBEN, W. The Prediction of Systematic and Specific Risk in Common Stocks. The Journal of Financial and Quantitative Analysis, v. 8, n. 2, p. 317333, Mar./1973).

ROSS S. A. et al. Administração financeira. Corporate Finance. São Paulo: Atlas, 1995. 
RYAN, Stephen G. A survey of research relating accounting numbers to systematic equity risk, with implications for risk disclosure policy and future research. Accounting Horizons, v. 11, issue 2, p. 82-95, June, 1997.

SANTOS, Mateus Alexandre Costa dos. O efeito dos componentes do lucro contábil no preço das ações autoria. In: ENCONTRO ANUAL DA ASSOCIAÇÃO NACIONAL DOS PROGRAMAS DE PÓS-GRADUAÇÃO EM ADMINISTRAÇÃO, 32., 2008. Anais... Rio de Janeiro: ANPAD, 2008.

SANTOS, M.; SILVA, M. Teoria de precificação por arbitragem: um estudo empírico no setor bancário brasileiro. Revista FAE, Curitiba, v.12, n.1, p.55-67, jan.-jun./2009.

SARLO NETO, Alfredo et al. Uma pesquisa sobre o perfil das ações brasileiras que reagem a publicação dos resultados contábeis. In: CONGRESSO USP CONTROLADORIA E CONTABILIDADE, 6., 2006, São Paulo. Anais... São Paulo: USP, 2006.

et al. A capacidade informacional dos resultados contábeis no mercado brasileiro: a diferença entre as ações ordinárias e as ações preferenciais. In: ENCONTRO ANUAL DA ASSOCIAÇÃO NACIONAL DOS PROGRAMAS DE PÓS-GRADUAÇÃO EM ADMINISTRAÇÃO. Anais... ANPAD, 2004.

SCARPIN, J. E. et al. A relevância da informação contábil e o mercado de capitais: uma análise empírica das empresas listadas no índice Brasil. In: CONGRESSO USP DE CONTROLADORIA E CONTABILIDADE, 7., 2007, São Paulo. Anais... São Paulo: USP, 2007.

SCHIEHLL, E. O efeito da divulgação das demonstrações contábeis no mercado de capitais brasileiro: um estudo sobre a variação no preço das ações. In: ENCONTRO ANUAL DA ASSOCIAÇÃO NACIONAL DOS PROGRAMAS DE PÓS-GRADUAÇÃO EM ADMINISTRAÇÃO, 20., 1996, Angra dos Reis. Anais... Angra dos Reis: ANPAD, 1996.

SECURATO, José Roberto. Decisões financeiras em contexto de risco. São Paulo: Atlas, 1993.

SHARPE, W. F. Simplified model for portfolio analyzes. Management Science, v. 9, n. 12, p. 277-293, Jan./1963.

Capital asset prices: a theory of market equilibrium. Journal of Finance, Sep./1964.

SILVA, E. D.; MENEZES, E. M. Metodologia de pesquisa e elaboração de dissertação. Florianópolis: UFSC, 2000.

ST. PIERRE, J.; BAHRI, M. The use of the accounting beta as an overall risk indicator for unlisted companies. Journal of Small Business and Enterprise Development. Emerald Group Publishing Limited. Vol. 13, n. 4, p. 546-561, 2006.

STEVENSON, William J. Estatística aplicada à administração. São Paulo: Harper \& Row do Brasil, 1981.

STRONGER, W.; WALKER, R. The incremental information content of the exception and extraordinary components off all-inlclusive earnings. Working Paper. University of Manchester, 1993. 
TEIXEIRA, S. C.; VALLE, M. R. Associação entre beta contábil e beta de mercado: análise para mercado financeiro brasileiro. In: CONGRESSO USP DE CONTROLADORIA E CONTABILIDADE, 8., 2008, São Paulo. Anais... São Paulo: USP, 2008.

THOMPSON, D. Sources of Systematic Risk in Common Stocks. The Journal of Business, v. 49, n. 2, p. 173-188, Apr./1976.

TRIVIÑOS, Augusto N. S. Introdução à pesquisa em ciências sociais. São Paulo: Atlas, 1987

URRUTIA, J. A. Test of random walk and efficiency for Latin America equity markets. Journal of Financial Research, v. 18, n. 3, p. 299-309, 1995.

Verbeek, Marno. A Guide to Modern Econometrics. New York: John Wiley \& Sons, 2000.

VERRECCHIA, R. Essays on disclosure. Journal of Accounting and Economics, v.32, p.97-180, 2001.

WATTS, R. L.; ZIMMERMAN, J. L. Potitive accounting theory. Englewood Cliffs: Prentice Hall, 1986.

WERNECK, M. A., et al. Um estudo empírico dos modelos residual income valuation Ohlson (1995) versus Piotroski (2000) no mercado brasileiro. In: ENCONTRO ANUAL DA ASSOCIAÇÃO NACIONAL DOS PROGRAMAS DE PÓS-GRADUAÇÃO EM ADMINISTRAÇÃO, 31., 2007, Rio de Janeiro. Anais... Rio de Janeiro: ANPAD, 2007.

WESTON, J. F.; BRIGHAM, E. F. Fundamentos da administração financeira. Tradução: S. Stancatti. 10th ed. Obra original publicada em 1996. São Paulo: Makron Books, 2000.

WOOLDRIDGE, Jeffrey M. Introductory econometrics: a modern approach. $2^{\text {nd }}$ ed. Ohio: Thomson South-Western College Publishing, 2003

YOUNG, S. D.; O'BYRNE, S. F. EVA e gestão baseada em valor: guia prático para implementação. Porto Alegre: Bookman, 2003. 

ANEXO 1

\begin{tabular}{|c|c|c|c|c|c|c|}
\hline \multicolumn{7}{|c|}{ CORRELAÇÃO DE PEARSON: LUCRO LÍQUIDO } \\
\hline BETA CONTÁBIL & $\begin{array}{l}\text { BM COV } \\
\text { MÉDIO }\end{array}$ & $\begin{array}{l}\text { BM COV } \\
\text { IBOV }\end{array}$ & BM REGR & \begin{tabular}{|l|} 
BM \\
DESALAVA \\
NCADO \\
BRIMBLE \\
\end{tabular} & \begin{tabular}{|l|} 
BM \\
DESALAVA \\
NCADO \\
VALLE \\
\end{tabular} & $\begin{array}{l}\text { DESVIO } \\
\text { PADRÃO }\end{array}$ \\
\hline $\mathrm{LL}$ & $-0,02$ & 0,13 & 0,30 & $-0,15$ & $-0,01$ & $-0,13$ \\
\hline DIF LL & $-0,03$ & 0,10 & 0,29 & $-0,14$ & $-0,02$ & $-0,12$ \\
\hline$\% \mathrm{LL}$ & 0,00 & 0,09 & 0,13 & $-0,07$ & $-0,03$ & $-0,06$ \\
\hline $\mathrm{LL} / \mathrm{PL}$ & 0,11 & 0,10 & $-0,15$ & 0,06 & 0,00 & 0,04 \\
\hline DIF LL/PL & 0,06 & 0,07 & $-0,14$ & 0,07 & $-0,04$ & 0,03 \\
\hline$\% \mathrm{LL} / \mathrm{PL}$ & 0,00 & 0,09 & 0,13 & $-0,07$ & $-0,03$ & $-0,06$ \\
\hline LL/AT & 0,09 & 0,07 & $-0,07$ & 0,30 & $-0,05$ & 0,02 \\
\hline DIF LL/AT & 0,09 & 0,07 & $-0,08$ & 0,30 & $-0,05$ & 0,02 \\
\hline$\%$ LL/AT & 0,00 & 0,09 & 0,13 & $-0,07$ & $-0,03$ & $-0,06$ \\
\hline LL/VM & 0,11 & 0,09 & $-0,06$ & 0,36 & 0,01 & 0,02 \\
\hline DIF LL/VM & 0,10 & 0,09 & $-0,06$ & 0,36 & 0,01 & 0,02 \\
\hline$\%$ LL/VM & $-0,02$ & $-0,01$ & 0,04 & 0,07 & $-0,04$ & $-0,04$ \\
\hline \multicolumn{7}{|l|}{$\begin{array}{l}\text { MÉDIA VAR. } \\
\text { CONT. }\end{array}$} \\
\hline $\mathrm{LL}$ & $-0,02$ & 0,14 & 0,30 & $-0,15$ & $-0,01$ & $-0,13$ \\
\hline DIF LL & $-0,02$ & 0,15 & 0,29 & $-0,14$ & $-0,01$ & $-0,12$ \\
\hline$\% \mathrm{LL}$ & $-0,01$ & 0,09 & 0,15 & $-0,07$ & 0,02 & $-0,07$ \\
\hline $\mathrm{LL} / \mathrm{PL}$ & 0,17 & 0,22 & $-0,02$ & $-0,12$ & $-0,04$ & 0,04 \\
\hline DIF LL/PL & $-0,12$ & $-0,08$ & $-0,08$ & $-0,13$ & $-0,06$ & 0,00 \\
\hline$\%$ LL/PL & $-0,01$ & 0,09 & 0,15 & $-0,08$ & 0,02 & $-0,07$ \\
\hline LL/AT & $-0,06$ & 0,04 & 0,10 & $-0,13$ & $-0,04$ & $-0,08$ \\
\hline DIF LL/AT & 0,05 & 0,08 & 0,18 & $-0,34$ & 0,02 & $-0,03$ \\
\hline$\%$ LL/AT & $-0,01$ & 0,10 & 0,15 & $-0,07$ & 0,02 & $-0,07$ \\
\hline LL/VM & 0,04 & 0,06 & $-0,04$ & 0,30 & 0,03 & 0,01 \\
\hline DIF LL/VM & $-0,10$ & $-0,13$ & $-0,02$ & $-0,23$ & $-0,04$ & 0,01 \\
\hline$\%$ LL/VM & 0,00 & 0,01 & 0,03 & 0,16 & $-0,01$ & $-0,03$ \\
\hline \multicolumn{7}{|l|}{$\begin{array}{l}\text { DESVIO PADRÃO } \\
\text { VAR. CONT. }\end{array}$} \\
\hline LL & $-0,02$ & 0,16 & 0,28 & $-0,13$ & $-0,03$ & $-0,13$ \\
\hline DIF LL & $-0,01$ & 0,16 & 0,26 & $-0,12$ & $-0,03$ & $-0,13$ \\
\hline$\% \mathrm{LL}$ & $-0,01$ & 0,10 & 0,14 & $-0,08$ & 0,00 & $-0,07$ \\
\hline $\mathrm{LL} / \mathrm{PL}$ & 0,07 & 0,02 & $-0,38$ & 0,19 & 0,06 & 0,11 \\
\hline DIF LL/PL & 0,07 & 0,02 & $-0,38$ & 0,19 & 0,06 & 0,11 \\
\hline$\%$ LL/PL & $-0,01$ & 0,09 & 0,14 & $-0,08$ & 0,00 & $-0,07$ \\
\hline LL/AT & 0,07 & 0,04 & $-0,11$ & 0,33 & $-0,06$ & 0,03 \\
\hline DIF LL/AT & 0,07 & 0,04 & $-0,11$ & 0,33 & $-0,06$ & 0,03 \\
\hline$\%$ LL/AT & $-0,01$ & 0,10 & 0,14 & $-0,08$ & 0,00 & $-0,07$ \\
\hline LL/VM & 0,12 & 0,10 & $-0,06$ & 0,37 & 0,00 & 0,03 \\
\hline DIF LL/VM & 0,12 & 0,10 & $-0,06$ & 0,37 & 0,00 & 0,03 \\
\hline$\%$ LL/VM & $-0,02$ & $-0,01$ & 0,03 & 0,11 & $-0,02$ & $-0,04$ \\
\hline
\end{tabular}




\begin{tabular}{|c|c|c|c|c|c|c|}
\hline \multicolumn{7}{|c|}{ CORRELAÇÃO DE PEARSON: EBIT } \\
\hline BETA CONTÁBIL & $\begin{array}{l}\text { BM COV } \\
\text { MÉDIO } \\
\end{array}$ & $\begin{array}{l}\text { BM COV } \\
\text { IBOV }\end{array}$ & BM REGR & \begin{tabular}{|l|} 
BM \\
DESALAV \\
ANCADO \\
BRIMBLE \\
\end{tabular} & \begin{tabular}{|l|} 
BM \\
DESALAV \\
ANCADO \\
VALLE \\
\end{tabular} & $\begin{array}{l}\text { DESVIO } \\
\text { PADRÃOO }\end{array}$ \\
\hline EBIT & 0,11 & 0,07 & 0,14 & 0,09 & $-0,05$ & $-0,03$ \\
\hline DIF EBIT & 0,09 & 0,09 & 0,15 & 0,04 & $-0,16$ & $-0,05$ \\
\hline$\%$ EBIT & $-0,14$ & $-0,17$ & $-0,13$ & 0,00 & $-0,01$ & $-0,05$ \\
\hline $\mathrm{EBIT} / \mathrm{PL}$ & $-0,06$ & 0,02 & $-0,16$ & $-0,05$ & 0,00 & 0,02 \\
\hline DIF EBIT/PL & $-0,06$ & 0,01 & $-0,16$ & $-0,05$ & 0,00 & 0,02 \\
\hline$\% \mathrm{EBIT} / \mathrm{PL}$ & $-0,15$ & $-0,18$ & $-0,13$ & 0,01 & $-0,03$ & $-0,06$ \\
\hline EBIT/AT & 0,12 & 0,08 & $-0,05$ & 0,27 & $-0,05$ & 0,02 \\
\hline DIF EBIT/AT & 0,10 & 0,07 & $-0,08$ & 0,27 & $-0,06$ & 0,03 \\
\hline$\%$ EBIT/AT & $-0,12$ & $-0,14$ & $-0,14$ & $-0,01$ & 0,01 & $-0,03$ \\
\hline EBIT/VM & 0,10 & 0,09 & $-0,05$ & 0,35 & 0,01 & 0,02 \\
\hline DIF EBIT/VM & 0,09 & 0,09 & $-0,06$ & 0,35 & 0,02 & 0,02 \\
\hline$\% \mathrm{EBIT} / \mathrm{VM}$ & $-0,17$ & $-0,17$ & $-0,11$ & $-0,01$ & $-0,05$ & $-0,08$ \\
\hline \multicolumn{7}{|l|}{ MÉDIA VAR. CONT. } \\
\hline EBIT & 0,11 & 0,07 & 0,11 & 0,05 & $-0,05$ & $-0,03$ \\
\hline DIF EBIT & $-0,01$ & 0,07 & 0,09 & $-0,06$ & $-0,26$ & $-0,06$ \\
\hline \% EBIT & $-0,16$ & $-0,14$ & $-0,05$ & 0,01 & $-0,03$ & $-0,10$ \\
\hline $\mathrm{EBIT} / \mathrm{PL}$ & 0,13 & 0,07 & 0,09 & 0,08 & $-0,03$ & $-0,01$ \\
\hline DIF EBIT/PL & $-0,11$ & $-0,09$ & $-0,20$ & $-0,08$ & $-0,22$ & 0,02 \\
\hline$\% \mathrm{EBIT} / \mathrm{PL}$ & $-0,17$ & $-0,16$ & $-0,04$ & 0,03 & $-0,03$ & $-0,10$ \\
\hline EBIT/AT & 0,09 & 0,06 & $-0,04$ & 0,31 & $-0,07$ & 0,01 \\
\hline DIF EBIT/AT & 0,06 & 0,07 & $-0,03$ & 0,22 & $-0,07$ & 0,00 \\
\hline$\%$ EBIT/AT & $-0,13$ & $-0,11$ & $-0,05$ & 0,00 & 0,00 & $-0,08$ \\
\hline EBIT/VM & 0,10 & 0,09 & $-0,06$ & 0,36 & 0,01 & 0,02 \\
\hline DIF EBIT/VM & 0,06 & 0,07 & $-0,06$ & 0,34 & 0,03 & 0,01 \\
\hline$\%$ EBIT/VM & $-0,15$ & $-0,18$ & $-0,11$ & 0,03 & $-0,02$ & $-0,05$ \\
\hline \multicolumn{7}{|l|}{$\begin{array}{l}\text { DESVIO PADRÃO } \\
\text { VAR. CONT. }\end{array}$} \\
\hline EBIT & $-0,03$ & 0,02 & $-0,12$ & $-0,01$ & $-0,04$ & 0,01 \\
\hline DIF EBIT & $-0,04$ & 0,08 & 0,12 & $-0,10$ & 0,09 & $-0,07$ \\
\hline$\%$ EBIT & $-0,12$ & $-0,14$ & $-0,12$ & 0,00 & $-0,02$ & $-0,03$ \\
\hline EBIT/PL & $-0,05$ & 0,02 & $-0,19$ & $-0,03$ & 0,00 & 0,03 \\
\hline DIF EBIT/PL & $-0,06$ & 0,01 & $-0,18$ & $-0,04$ & 0,01 & 0,03 \\
\hline$\%$ EBIT/PL & $-0,12$ & $-0,13$ & $-0,12$ & 0,00 & $-0,03$ & $-0,03$ \\
\hline EBIT/AT & 0,04 & 0,05 & $-0,14$ & 0,23 & $-0,05$ & 0,03 \\
\hline DIF EBIT/AT & 0,01 & 0,04 & $-0,15$ & 0,18 & $-0,04$ & 0,03 \\
\hline$\%$ EBIT/AT & $-0,11$ & $-0,12$ & $-0,12$ & $-0,02$ & $-0,01$ & $-0,02$ \\
\hline EBIT/VM & 0,10 & 0,09 & $-0,06$ & 0,37 & 0,01 & 0,02 \\
\hline DIF EBIT/VM & 0,11 & 0,10 & $-0,07$ & 0,39 & $-0,01$ & 0,02 \\
\hline$\%$ EBIT/VM & $-0,16$ & $-0,18$ & $-0,14$ & 0,00 & $-0,07$ & $-0,07$ \\
\hline
\end{tabular}




\begin{tabular}{|c|c|c|c|c|c|c|}
\hline \multicolumn{7}{|c|}{ CORRELAÇÃO DE PEARSON: LAIR } \\
\hline BETA CONTÁBIL & $\begin{array}{l}\text { BM COV } \\
\text { MÉDIO }\end{array}$ & $\begin{array}{l}\text { BM COV } \\
\text { IBOV }\end{array}$ & BM REGR & \begin{tabular}{|l|} 
BM \\
DESALAV \\
ANCADO \\
BRIMBLE \\
\end{tabular} & \begin{tabular}{|l|} 
BM \\
DESALAV \\
ANCADO \\
VALLE \\
\end{tabular} & \begin{tabular}{|l} 
DESVIO \\
PADRÃO
\end{tabular} \\
\hline LAIR & $-0,09$ & 0,01 & \begin{tabular}{|r|}
0,34 \\
\end{tabular} & $-0,15$ & $-0,01$ & $-0,15$ \\
\hline DIF LAIR & $-0,10$ & $-0,02$ & 0,29 & $-0,11$ & $-0,03$ & $-0,13$ \\
\hline$\%$ LAIR & 0,06 & 0,12 & 0,03 & $-0,07$ & $-0,03$ & $-0,02$ \\
\hline LAIR/PL & $-0,10$ & $-0,11$ & $-0,10$ & $-0,03$ & 0,13 & 0,00 \\
\hline DIF LAIR/PL & $-0,10$ & $-0,11$ & $-0,10$ & $-0,03$ & 0,13 & 0,00 \\
\hline$\%$ LAIR/PL & 0,06 & 0,12 & 0,03 & $-0,07$ & $-0,03$ & $-0,02$ \\
\hline LAIR/AT & 0,10 & 0,07 & $-0,06$ & 0,23 & $-0,04$ & 0,03 \\
\hline DIF LAIR/AT & 0,09 & 0,06 & $-0,06$ & 0,23 & $-0,04$ & 0,03 \\
\hline$\%$ LAIR/AT & 0,06 & 0,12 & 0,03 & $-0,07$ & $-0,03$ & $-0,02$ \\
\hline LAIR/VM & 0,02 & 0,08 & 0,02 & 0,07 & $-0,03$ & $-0,03$ \\
\hline DIF LAIR/VM & 0,05 & 0,10 & 0,00 & 0,11 & $-0,03$ & $-0,02$ \\
\hline$\%$ LAIR/VM & $-0,02$ & 0,01 & 0,05 & $-0,04$ & 0,02 & $-0,04$ \\
\hline \multicolumn{7}{|l|}{$\begin{array}{l}\text { MÉDIA VAR. } \\
\text { CONT. }\end{array}$} \\
\hline LAIR & $-0,04$ & 0,07 & 0,37 & $-0,17$ & $-0,03$ & $-0,11$ \\
\hline DIF LAIR & $-0,12$ & $-0,05$ & 0,31 & $-0,12$ & $-0,04$ & $-0,14$ \\
\hline$\%$ LAIR & 0,08 & 0,13 & 0,03 & $-0,07$ & $-0,04$ & 0,00 \\
\hline LAIR/PL & $-0,09$ & $-0,12$ & $-0,09$ & $-0,04$ & 0,13 & 0,00 \\
\hline DIF LAIR/PL & $-0,08$ & $-0,08$ & 0,04 & $-0,15$ & $-0,09$ & $-0,01$ \\
\hline$\%$ LAIR/PL & 0,08 & 0,13 & 0,03 & $-0,07$ & $-0,05$ & 0,00 \\
\hline LAIR/AT & 0,10 & 0,06 & $-0,06$ & 0,23 & $-0,04$ & 0,04 \\
\hline DIF LAIR/AT & 0,10 & 0,07 & $-0,07$ & 0,23 & $-0,04$ & 0,03 \\
\hline$\%$ LAIR/AT & 0,08 & 0,13 & 0,03 & $-0,07$ & $-0,04$ & 0,00 \\
\hline LAIR/VM & 0,03 & 0,10 & 0,01 & 0,14 & $-0,04$ & $-0,03$ \\
\hline DIF LAIR/VM & 0,03 & 0,07 & $-0,08$ & 0,20 & 0,00 & 0,01 \\
\hline$\%$ LAIR/VM & $-0,02$ & 0,01 & 0,04 & $-0,03$ & 0,01 & $-0,04$ \\
\hline \multicolumn{7}{|l|}{$\begin{array}{l}\text { DESVIO PADRÃO } \\
\text { VAR. CONT. }\end{array}$} \\
\hline LAIR & 0,02 & 0,09 & 0,32 & $-0,15$ & 0,00 & $-0,04$ \\
\hline DIF LAIR & 0,04 & 0,11 & 0,31 & $-0,15$ & 0,00 & $-0,02$ \\
\hline$\%$ LAIR & 0,07 & 0,13 & 0,03 & $-0,08$ & $-0,02$ & $-0,02$ \\
\hline LAIR/PL & $-0,09$ & $-0,12$ & $-0,11$ & $-0,02$ & 0,13 & 0,01 \\
\hline DIF LAIR/PL & $-0,09$ & $-0,12$ & $-0,11$ & $-0,02$ & 0,13 & 0,01 \\
\hline$\%$ LAIR/PL & 0,07 & 0,13 & 0,03 & $-0,08$ & $-0,02$ & $-0,02$ \\
\hline LAIR/AT & 0,11 & 0,07 & $-0,07$ & 0,23 & $-0,04$ & 0,05 \\
\hline DIF LAIR/AT & 0,12 & 0,07 & $-0,08$ & 0,23 & $-0,04$ & 0,07 \\
\hline$\%$ LAIR/AT & 0,07 & 0,13 & 0,03 & $-0,08$ & $-0,02$ & $-0,01$ \\
\hline LAIR/VM & 0,05 & 0,10 & $-0,02$ & 0,17 & $-0,03$ & $-0,02$ \\
\hline DIF LAIR/VM & 0,06 & 0,11 & $-0,04$ & 0,20 & $-0,03$ & $-0,01$ \\
\hline$\%$ LAIR/VM & $-0,02$ & 0,02 & 0,05 & $-0,04$ & 0,02 & $-0,05$ \\
\hline
\end{tabular}




\begin{tabular}{|c|c|c|c|c|c|c|}
\hline \multicolumn{7}{|c|}{ CORRELAÇÃO DE PEARSON: MTB } \\
\hline BETA CONTÁBIL & $\begin{array}{l}\text { BM COV } \\
\text { MÉDIO }\end{array}$ & $\begin{array}{l}\text { BM COV } \\
\text { IBOV }\end{array}$ & BM REGR & \begin{tabular}{|l|} 
BM \\
DESALAV \\
ANCADO \\
BRIMBLE \\
\end{tabular} & \begin{tabular}{|l} 
BM \\
DESALAV \\
ANCADO \\
VALLE \\
\end{tabular} & $\begin{array}{l}\text { DESVIO } \\
\text { PADRÃO }\end{array}$ \\
\hline BETA & BM1 & BM2 & \begin{tabular}{|l|l} 
BM3 & 1 \\
\end{tabular} & \begin{tabular}{|l|l} 
BM4 & 1 \\
\end{tabular} & BM5 & BM6 \\
\hline MKTB & $-0,04$ & $-0,13$ & $-0,09$ & \begin{tabular}{r|}
$-0,09$ \\
\end{tabular} & 0,13 & \begin{tabular}{|r|}
0,01 \\
\end{tabular} \\
\hline DIF MKTB & $-0,07$ & $-0,15$ & $-0,10$ & $-0,07$ & 0,13 & $-0,01$ \\
\hline$\%$ MKTB & $-0,03$ & $-0,23$ & $-0,24$ & 0,30 & 0,00 & 0,32 \\
\hline MKTB/PL & $-0,16$ & $-0,15$ & $-0,18$ & $-0,14$ & $-0,08$ & 0,02 \\
\hline DIF MKTB/PL & $-0,15$ & $-0,15$ & $-0,19$ & $-0,13$ & $-0,07$ & 0,03 \\
\hline$\% \mathrm{MKTB} / \mathrm{PL}$ & $-0,02$ & 0,03 & 0,00 & $-0,06$ & 0,02 & $-0,04$ \\
\hline MKTB/AT & $-0,15$ & $-0,11$ & $-0,18$ & 0,42 & $-0,04$ & $-0,03$ \\
\hline DIF MKTB/AT & $-0,13$ & $-0,17$ & $-0,29$ & 0,24 & $-0,04$ & 0,08 \\
\hline$\%$ MKTB/AT & 0,13 & $-0,01$ & $-0,16$ & 0,22 & $-0,05$ & 0,13 \\
\hline MKTB/VM & $-0,11$ & $-0,13$ & $-0,04$ & $-0,08$ & $-0,03$ & $-0,05$ \\
\hline DIF MKTB/VM & $-0,12$ & $-0,14$ & $-0,06$ & $-0,08$ & $-0,04$ & $-0,05$ \\
\hline$\%$ MKTB/VM & $-0,10$ & $-0,09$ & 0,02 & $-0,10$ & 0,06 & $-0,03$ \\
\hline \multicolumn{7}{|l|}{ MÉDIA VAR. CONT. } \\
\hline MKTB & 0,11 & 0,04 & 0,05 & $-0,18$ & 0,08 & 0,06 \\
\hline DIF MKTB & 0,04 & 0,06 & $-0,04$ & 0,11 & $-0,01$ & 0,05 \\
\hline$\%$ MKTB & $-0,08$ & $-0,34$ & $-0,33$ & 0,30 & 0,01 & 0,29 \\
\hline MKTB/PL & $-0,03$ & $-0,13$ & $-0,35$ & 0,06 & 0,15 & 0,14 \\
\hline DIF MKTB/PL & $-0,14$ & $-0,14$ & $-0,21$ & $-0,03$ & $-0,08$ & 0,04 \\
\hline$\% \mathrm{MKTB} / \mathrm{PL}$ & $-0,04$ & $-0,08$ & $-0,33$ & 0,21 & 0,12 & 0,09 \\
\hline MKTB/AT & 0,14 & $-0,04$ & $-0,10$ & $-0,32$ & 0,04 & 0,22 \\
\hline DIF MKTB/AT & $-0,05$ & $-0,09$ & $-0,21$ & 0,32 & $-0,02$ & 0,12 \\
\hline$\%$ MKTB/AT & 0,00 & $-0,27$ & $-0,31$ & 0,32 & $-0,07$ & 0,22 \\
\hline MKTB/VM & $-0,05$ & $-0,08$ & 0,01 & $-0,06$ & 0,01 & $-0,03$ \\
\hline DIF MKTB/VM & $-0,16$ & $-0,14$ & $-0,20$ & $-0,13$ & $-0,05$ & 0,01 \\
\hline$\%$ MKTB/VM & 0,07 & 0,08 & 0,23 & $-0,22$ & 0,25 & $-0,02$ \\
\hline \multicolumn{7}{|l|}{$\begin{array}{l}\text { DESVIO PADRÃO } \\
\text { VAR. CONT. }\end{array}$} \\
\hline MKTB & 0,01 & $-0,10$ & $-0,17$ & $-0,01$ & 0,14 & 0,07 \\
\hline DIF MKTB & $-0,02$ & $-0,12$ & $-0,16$ & $-0,04$ & 0,16 & 0,05 \\
\hline$\%$ MKTB & 0,01 & $-0,22$ & $-0,43$ & 0,43 & 0,04 & 0,35 \\
\hline MKTB/PL & $-0,02$ & $-0,11$ & $-0,32$ & 0,03 & 0,16 & 0,13 \\
\hline DIF MKTB/PL & $-0,02$ & $-0,10$ & $-0,31$ & 0,03 & 0,16 & 0,12 \\
\hline$\% \mathrm{MKTB} / \mathrm{PL}$ & $-0,08$ & $-0,11$ & $-0,29$ & 0,17 & 0,09 & 0,07 \\
\hline MKTB/AT & 0,02 & $-0,10$ & $-0,33$ & 0,40 & 0,02 & 0,20 \\
\hline DIF MKTB/AT & $-0,02$ & $-0,13$ & $-0,35$ & 0,34 & 0,05 & 0,18 \\
\hline$\%$ MKTB/AT & 0,10 & $-0,13$ & $-0,37$ & 0,38 & $-0,02$ & 0,28 \\
\hline MKTB/VM & $-0,09$ & $-0,11$ & $-0,05$ & $-0,09$ & $-0,02$ & $-0,03$ \\
\hline DIF MKTB/VM & $-0,09$ & $-0,11$ & $-0,06$ & $-0,09$ & $-0,02$ & $-0,03$ \\
\hline$\%$ MKTB/VM & $-0,14$ & $-0,13$ & $-0,04$ & $-0,02$ & 0,03 & $-0,05$ \\
\hline
\end{tabular}




\begin{tabular}{|c|c|c|c|c|c|c|}
\hline \multicolumn{7}{|c|}{ CORRELAÇÃO DE PEARSON: RECEITA LÍQUIDA } \\
\hline BETA CONTÁBIL & $\begin{array}{l}\text { BM COV } \\
\text { MÉDIO }\end{array}$ & $\begin{array}{l}\text { BM COV } \\
\text { IBOV }\end{array}$ & BM REGR & $\begin{array}{l}\text { BM } \\
\text { DESALAV } \\
\text { ANCADO } \\
\text { BRIMBLE } \\
\end{array}$ & $\begin{array}{l}\text { BM } \\
\text { DESALAV } \\
\text { ANCADO } \\
\text { VALLE } \\
\end{array}$ & $\begin{array}{l}\text { DESVIO } \\
\text { PADRÃO }\end{array}$ \\
\hline BETA & BM1 & BM2 & BM3 & BM4 & BM5 & BM6 \\
\hline REC & 0,07 & 0,14 & 0,10 & $-0,06$ & $-0,05$ & $-0,08$ \\
\hline DIF REC & 0,07 & 0,15 & 0,11 & $-0,05$ & $-0,06$ & $-0,08$ \\
\hline$\%$ REC & 0,14 & 0,10 & $-0,10$ & 0,01 & $-0,02$ & 0,05 \\
\hline $\mathrm{REC} / \mathrm{PL}$ & 0,13 & 0,14 & $-0,07$ & 0,01 & $-0,04$ & 0,03 \\
\hline DIF REC/PL & 0,13 & 0,14 & $-0,07$ & 0,01 & $-0,04$ & 0,02 \\
\hline$\%$ REC/PL & 0,14 & 0,10 & $-0,10$ & 0,00 & $-0,02$ & 0,05 \\
\hline REC/AT & 0,10 & 0,07 & $-0,07$ & 0,27 & $-0,05$ & 0,03 \\
\hline DIF REC/AT & 0,09 & 0,06 & $-0,07$ & 0,28 & $-0,05$ & 0,03 \\
\hline$\%$ REC/AT & 0,14 & 0,11 & $-0,10$ & 0,00 & $-0,02$ & 0,05 \\
\hline REC/VM & 0,10 & 0,09 & $-0,06$ & 0,36 & 0,01 & 0,03 \\
\hline DIF REC/VM & 0,11 & 0,09 & $-0,06$ & 0,36 & 0,01 & 0,02 \\
\hline$\%$ REC/VM & 0,12 & 0,18 & 0,05 & 0,11 & $-0,01$ & $-0,02$ \\
\hline \multicolumn{7}{|c|}{ MÉDIA VAR. CONT. } \\
\hline REC & 0,03 & 0,12 & 0,17 & $-0,08$ & $-0,04$ & $-0,11$ \\
\hline DIF REC & $-0,03$ & 0,11 & 0,20 & $-0,14$ & $-0,02$ & $-0,12$ \\
\hline$\%$ REC & 0,08 & 0,18 & 0,05 & $-0,07$ & $-0,06$ & $-0,03$ \\
\hline $\mathrm{REC} / \mathrm{PL}$ & 0,14 & 0,15 & $-0,07$ & 0,08 & $-0,02$ & 0,02 \\
\hline DIF REC/PL & $-0,07$ & $-0,06$ & $-0,18$ & $-0,22$ & $-0,04$ & 0,06 \\
\hline$\% \mathrm{REC} / \mathrm{PL}$ & 0,09 & 0,19 & 0,05 & $-0,07$ & $-0,06$ & $-0,02$ \\
\hline REC/AT & 0,08 & 0,05 & $-0,07$ & 0,32 & $-0,06$ & 0,02 \\
\hline DIF REC/AT & 0,13 & 0,12 & $-0,09$ & $-0,23$ & 0,05 & 0,09 \\
\hline$\%$ REC/AT & 0,08 & 0,18 & 0,05 & $-0,07$ & $-0,06$ & $-0,03$ \\
\hline REC/VM & 0,11 & 0,09 & $-0,06$ & 0,36 & 0,01 & 0,02 \\
\hline DIF REC/VM & $-0,09$ & $-0,09$ & 0,03 & $-0,32$ & $-0,01$ & $-0,01$ \\
\hline$\%$ REC/VM & $-0,04$ & $-0,03$ & $-0,05$ & $-0,23$ & $-0,06$ & $-0,01$ \\
\hline \multicolumn{7}{|l|}{$\begin{array}{l}\text { DESVIO PADRÃO } \\
\text { VAR. CONT. }\end{array}$} \\
\hline REC & 0,04 & 0,19 & 0,25 & $-0,13$ & $-0,08$ & $-0,14$ \\
\hline DIF REC & 0,04 & 0,20 & 0,25 & $-0,12$ & $-0,08$ & $-0,14$ \\
\hline$\%$ REC & 0,05 & 0,13 & 0,11 & $-0,03$ & $-0,08$ & $-0,05$ \\
\hline $\mathrm{REC} / \mathrm{PL}$ & 0,13 & 0,12 & $-0,14$ & 0,09 & $-0,04$ & 0,04 \\
\hline DIF REC/PL & 0,14 & 0,13 & $-0,13$ & 0,09 & $-0,04$ & 0,04 \\
\hline$\%$ REC/PL & 0,06 & 0,13 & 0,10 & $-0,03$ & $-0,08$ & $-0,05$ \\
\hline REC/AT & 0,09 & 0,06 & $-0,07$ & 0,28 & $-0,05$ & 0,02 \\
\hline DIF REC/AT & 0,09 & 0,06 & $-0,07$ & 0,29 & $-0,05$ & 0,02 \\
\hline$\%$ REC/AT & 0,06 & 0,13 & 0,11 & $-0,03$ & $-0,08$ & $-0,05$ \\
\hline REC/VM & 0,11 & 0,10 & $-0,06$ & 0,37 & 0,00 & 0,02 \\
\hline DIF REC/VM & 0,11 & 0,10 & $-0,06$ & 0,37 & 0,00 & 0,02 \\
\hline$\%$ REC/VM & 0,03 & 0,05 & $-0,09$ & 0,26 & $-0,03$ & 0,00 \\
\hline
\end{tabular}


CORRELAÇÃO DE PEARSON: CAPITAL DE GIRO

\begin{tabular}{|c|c|c|c|c|c|c|}
\hline BETA CONTÁBIL & $\begin{array}{l}\text { BM COV } \\
\text { MÉDIO }\end{array}$ & $\begin{array}{l}\text { BM COV } \\
\text { IBOV }\end{array}$ & BM REGR & $\begin{array}{l}\text { BM } \\
\text { DESALAV } \\
\text { ANCADO } \\
\text { BRIMBLE } \\
\end{array}$ & $\begin{array}{l}\text { BM } \\
\text { DESALAV } \\
\text { ANCADO } \\
\text { VALLE } \\
\end{array}$ & $\begin{array}{l}\text { DESVIO } \\
\text { PADRÃO }\end{array}$ \\
\hline CAP GIRO & 0,11 & 0,07 & $-0,08$ & 0,25 & $-0,04$ & 0,05 \\
\hline DIF CAP GIRO & 0,12 & 0,06 & $-0,16$ & 0,32 & $-0,05$ & 0,09 \\
\hline$\%$ CAP GIRO & $-0,22$ & $-0,13$ & $-0,02$ & 0,05 & $-0,09$ & $-0,16$ \\
\hline CAP GIRO/PL & $-0,06$ & $-0,12$ & $-0,24$ & 0,11 & 0,05 & 0,07 \\
\hline DIF CAP GIRO/PL & $-0,09$ & $-0,14$ & $-0,24$ & 0,10 & 0,04 & 0,06 \\
\hline$\%$ CAP GIRO/PL & $-0,20$ & $-0,12$ & $-0,03$ & 0,06 & $-0,08$ & $-0,14$ \\
\hline CAP GIRO/AT & 0,10 & 0,07 & $-0,07$ & 0,24 & $-0,04$ & 0,03 \\
\hline DIF CAP GIRO/AT & 0,10 & 0,07 & $-0,07$ & 0,25 & $-0,04$ & 0,03 \\
\hline$\%$ CAP GIRO/AT & $-0,21$ & $-0,22$ & $-0,08$ & 0,00 & $-0,06$ & $-0,11$ \\
\hline CAP GIRO/VM & 0,17 & 0,09 & $-0,05$ & 0,12 & $-0,07$ & 0,03 \\
\hline DIF CAP GIRO/VM & 0,17 & 0,09 & $-0,05$ & 0,12 & $-0,07$ & 0,03 \\
\hline$\%$ CAP GIRO/VM & $-0,16$ & $-0,21$ & $-0,07$ & $-0,05$ & $-0,06$ & $-0,09$ \\
\hline \multicolumn{7}{|l|}{ MÉDIA VAR. CONT. } \\
\hline CAP GIRO & $-0,10$ & $-0,06$ & 0,11 & $-0,26$ & 0,04 & $-0,05$ \\
\hline DIF CAP GIRO & $-0,09$ & $-0,07$ & 0,08 & $-0,26$ & 0,04 & $-0,03$ \\
\hline$\%$ CAP GIRO & $-0,22$ & $-0,22$ & $-0,09$ & 0,04 & $-0,03$ & $-0,14$ \\
\hline CAP GIRO/PL & $-0,04$ & 0,07 & 0,08 & 0,21 & $-0,10$ & $-0,14$ \\
\hline DIF CAP GIRO/PL & 0,03 & 0,02 & $-0,14$ & 0,14 & $-0,08$ & 0,04 \\
\hline$\%$ CAP GIRO/PL & $-0,26$ & $-0,24$ & $-0,09$ & 0,04 & $-0,03$ & $-0,17$ \\
\hline CAP GIRO/AT & $-0,10$ & $-0,07$ & 0,07 & $-0,24$ & 0,04 & $-0,03$ \\
\hline DIF CAP GIRO/AT & $-0,10$ & $-0,07$ & 0,07 & $-0,24$ & 0,04 & $-0,03$ \\
\hline$\%$ CAP GIRO/AT & $-0,21$ & $-0,23$ & $-0,09$ & 0,00 & $-0,06$ & $-0,10$ \\
\hline CAP GIRO/VM & $-0,17$ & $-0,09$ & 0,05 & $-0,14$ & 0,08 & $-0,03$ \\
\hline DIF CAP GIRO/VM & $-0,03$ & $-0,03$ & 0,10 & $-0,40$ & $-0,01$ & $-0,04$ \\
\hline$\%$ CAP GIRO/VM & $-0,29$ & $-0,17$ & 0,08 & 0,01 & $-0,06$ & $-0,29$ \\
\hline \multicolumn{7}{|l|}{$\begin{array}{l}\text { DESVIO PADRÃO } \\
\text { VAR. CONT. }\end{array}$} \\
\hline CAP GIRO & 0,11 & 0,07 & $-0,08$ & 0,26 & $-0,04$ & 0,04 \\
\hline DIF CAP GIRO & 0,11 & 0,08 & $-0,10$ & 0,27 & $-0,05$ & 0,04 \\
\hline$\%$ CAP GIRO & $-0,05$ & $-0,10$ & $-0,07$ & $-0,02$ & $-0,06$ & 0,05 \\
\hline CAP GIRO/PL & $-0,10$ & $-0,20$ & $-0,38$ & 0,19 & 0,01 & 0,13 \\
\hline DIF CAP GIRO/PL & $-0,13$ & $-0,22$ & $-0,36$ & 0,12 & 0,02 & 0,11 \\
\hline$\%$ CAP GIRO/PL & $-0,02$ & $-0,08$ & $-0,09$ & 0,00 & $-0,05$ & 0,08 \\
\hline CAP GIRO/AT & 0,10 & 0,07 & $-0,07$ & 0,24 & $-0,04$ & 0,03 \\
\hline DIF CAP GIRO/AT & 0,10 & 0,07 & $-0,07$ & 0,24 & $-0,04$ & 0,03 \\
\hline$\%$ CAP GIRO/AT & $-0,18$ & $-0,21$ & $-0,09$ & $-0,02$ & $-0,06$ & $-0,07$ \\
\hline CAP GIRO/VM & 0,17 & 0,09 & $-0,05$ & 0,13 & $-0,08$ & 0,03 \\
\hline DIF CAP GIRO/VM & 0,17 & 0,09 & $-0,05$ & 0,13 & $-0,07$ & 0,03 \\
\hline \% CAP GIRO/VM & 0,00 & $-0,18$ & $-0,17$ & $-0,01$ & $-0,02$ & 0,11 \\
\hline
\end{tabular}




\begin{tabular}{|c|c|c|c|c|c|c|}
\hline \multicolumn{7}{|c|}{ CORRELAÇÃO DE PEARSON: LIQUIDEZ } \\
\hline BETA CONTÁBIL & $\begin{array}{l}\text { BM COV } \\
\text { MÉDIO }\end{array}$ & $\begin{array}{l}\text { BM COV } \\
\text { IBOV }\end{array}$ & BM REGR & $\begin{array}{l}\text { BM } \\
\text { DESALAV } \\
\text { ANCADO } \\
\text { BRIMBLE }\end{array}$ & \begin{tabular}{|l} 
BM \\
DESALAVA \\
NCADO \\
VALLE
\end{tabular} & $\begin{array}{l}\text { DESVIO } \\
\text { PADRÃO }\end{array}$ \\
\hline LIQ & 0,44 & 0,09 & $-0,21$ & $-0,02$ & 0,00 & 0,55 \\
\hline DIF LIQ & 0,44 & 0,09 & $-0,21$ & $-0,02$ & 0,00 & 0,55 \\
\hline$\% \mathrm{LIQ}$ & 0,47 & 0,11 & $-0,21$ & $-0,04$ & 0,01 & 0,57 \\
\hline $\mathrm{LIQ} / \mathrm{PL}$ & 0,42 & 0,07 & $-0,26$ & 0,00 & $-0,01$ & 0,56 \\
\hline DIF LIQ/PL & 0,42 & 0,07 & $-0,25$ & $-0,01$ & $-0,01$ & 0,56 \\
\hline$\% \mathrm{LIQ} / \mathrm{PL}$ & 0,47 & 0,11 & $-0,21$ & $-0,04$ & 0,01 & 0,57 \\
\hline LIQ/AT & 0,43 & 0,08 & $-0,23$ & 0,01 & 0,00 & 0,56 \\
\hline DIF LIQ/AT & 0,43 & 0,08 & $-0,23$ & 0,01 & 0,00 & 0,56 \\
\hline$\%$ LIQ/AT & 0,40 & 0,04 & $-0,23$ & $-0,04$ & 0,00 & 0,52 \\
\hline LIQ/VM & 0,29 & 0,01 & $-0,16$ & 0,03 & $-0,04$ & 0,33 \\
\hline DIF LIQ/VM & 0,29 & 0,02 & $-0,16$ & 0,02 & $-0,04$ & 0,33 \\
\hline \% LIQ/VM & 0,39 & 0,13 & $-0,15$ & 0,08 & $-0,06$ & 0,33 \\
\hline \multicolumn{7}{|l|}{ MÉDIA VAR. CONT. } \\
\hline LIQ & 0,15 & $-0,01$ & 0,00 & $-0,04$ & $-0,03$ & 0,17 \\
\hline DIF LIQ & $-0,05$ & $-0,02$ & 0,12 & $-0,08$ & $-0,05$ & $-0,07$ \\
\hline \% LIQ & 0,44 & 0,09 & $-0,18$ & $-0,04$ & 0,01 & 0,54 \\
\hline LIQ/PL & 0,38 & 0,03 & $-0,26$ & $-0,02$ & 0,04 & 0,53 \\
\hline DIF LIQ/PL & $-0,17$ & $-0,13$ & $-0,16$ & $-0,07$ & $-0,07$ & 0,00 \\
\hline$\% \mathrm{LIQ} / \mathrm{PL}$ & 0,42 & 0,07 & $-0,18$ & $-0,05$ & 0,02 & 0,53 \\
\hline LIQ/AT & 0,40 & 0,04 & $-0,23$ & 0,06 & 0,00 & 0,55 \\
\hline DIF LIQ/AT & $-0,13$ & 0,03 & 0,17 & $-0,09$ & $-0,05$ & $-0,24$ \\
\hline \% LIQ/AT & 0,39 & 0,04 & $-0,22$ & $-0,03$ & 0,00 & 0,52 \\
\hline LIQ/VM & 0,22 & $-0,03$ & $-0,20$ & 0,02 & $-0,06$ & 0,31 \\
\hline DIF LIQ/VM & $-0,15$ & $-0,09$ & 0,07 & 0,03 & 0,08 & $-0,10$ \\
\hline \% LIO/VM & 0,34 & 0,13 & $-0,13$ & 0,11 & $-0,07$ & 0,25 \\
\hline \multicolumn{7}{|l|}{$\begin{array}{l}\text { DESVIO PADRÃO } \\
\text { VAR. CONT. }\end{array}$} \\
\hline LIQ & 0,42 & 0,07 & $-0,20$ & $-0,01$ & 0,01 & 0,53 \\
\hline DIF LIQ & 0,42 & 0,08 & $-0,20$ & $-0,02$ & 0,00 & 0,53 \\
\hline$\%$ LIQ & 0,46 & 0,10 & $-0,20$ & $-0,04$ & 0,02 & 0,56 \\
\hline LIQ/PL & 0,39 & 0,04 & $-0,31$ & 0,04 & 0,00 & 0,56 \\
\hline DIF LIQ/PL & 0,39 & 0,05 & $-0,31$ & 0,02 & 0,00 & 0,56 \\
\hline$\% \mathrm{LIQ} / \mathrm{PL}$ & 0,47 & 0,11 & $-0,21$ & $-0,02$ & 0,01 & 0,56 \\
\hline LIQ/AT & 0,43 & 0,08 & $-0,23$ & 0,02 & 0,00 & 0,56 \\
\hline DIF LIQ/AT & 0,43 & 0,08 & $-0,23$ & 0,02 & 0,00 & 0,56 \\
\hline$\%$ LIQ/AT & 0,40 & 0,04 & $-0,22$ & $-0,03$ & 0,00 & 0,52 \\
\hline LIQ/VM & 0,28 & 0,01 & $-0,16$ & 0,03 & $-0,04$ & 0,33 \\
\hline DIF LIQ/VM & 0,29 & 0,01 & $-0,16$ & 0,03 & $-0,04$ & 0,33 \\
\hline \% LIO/VM & 0,39 & 0,14 & $-0,15$ & 0,09 & $-0,06$ & 0,33 \\
\hline
\end{tabular}


CORRELAÇÃO DE PEARSON: DÍVIDA LÍQUIDA

\begin{tabular}{|c|c|c|c|c|c|c|}
\hline BETA CONTÁBIL & $\begin{array}{l}\text { BM COV } \\
\text { MÉDIO }\end{array}$ & $\begin{array}{l}\text { BM COV } \\
\text { IBOV }\end{array}$ & BM REGR & \begin{tabular}{|l|} 
BM \\
DESALAV \\
ANCADO \\
BRIMBLE \\
\end{tabular} & \begin{tabular}{|l|} 
BM \\
DESALAV \\
ANCADO \\
VALLE \\
\end{tabular} & $\begin{array}{l}\text { DESVIO } \\
\text { PADRÃOO }\end{array}$ \\
\hline DIV & $-0,04$ & 0,01 & \begin{tabular}{|l|}
0,19 \\
\end{tabular} & $-0,05$ & 0,38 & $-0,05$ \\
\hline DIF DIV & $-0,05$ & 0,04 & 0,28 & $-0,07$ & 0,35 & $-0,09$ \\
\hline$\%$ DIV & $-0,12$ & $-0,12$ & $-0,10$ & 0,18 & $-0,07$ & $-0,01$ \\
\hline $\mathrm{DIV} / \mathrm{PL}$ & 0,22 & 0,16 & $-0,20$ & $-0,05$ & 0,30 & 0,15 \\
\hline DIF DIV/PL & 0,21 & 0,14 & $-0,19$ & $-0,05$ & 0,32 & 0,15 \\
\hline$\%$ DIV/PL & $-0,12$ & $-0,12$ & $-0,09$ & 0,18 & $-0,07$ & $-0,01$ \\
\hline DIV/AT & 0,10 & 0,07 & $-0,07$ & 0,26 & $-0,05$ & 0,04 \\
\hline DIF DIV/AT & 0,15 & 0,14 & 0,00 & 0,20 & 0,00 & 0,05 \\
\hline$\%$ DIV/AT & $-0,12$ & $-0,12$ & $-0,10$ & 0,19 & $-0,07$ & $-0,01$ \\
\hline DIV/VM & 0,17 & 0,09 & $-0,05$ & 0,13 & $-0,07$ & 0,04 \\
\hline DIF DIV/VM & 0,17 & 0,09 & $-0,05$ & 0,12 & $-0,07$ & 0,03 \\
\hline$\%$ DIV/VM & 0,02 & $-0,04$ & $-0,06$ & 0,12 & $-0,06$ & 0,00 \\
\hline \multicolumn{7}{|l|}{ MÉDIA VAR. CONT. } \\
\hline DIV & 0,02 & 0,05 & $-0,09$ & 0,00 & $-0,35$ & 0,00 \\
\hline DIF DIV & 0,03 & 0,01 & $-0,15$ & 0,03 & $-0,37$ & 0,03 \\
\hline$\%$ DIV & 0,13 & 0,13 & 0,13 & $-0,23$ & 0,02 & 0,00 \\
\hline DIV/PL & 0,24 & 0,17 & $-0,28$ & 0,00 & 0,20 & 0,16 \\
\hline DIF DIV/PL & 0,11 & 0,15 & $-0,04$ & 0,16 & $-0,26$ & $-0,04$ \\
\hline$\%$ DIV/PL & 0,13 & 0,13 & 0,13 & $-0,22$ & 0,03 & 0,01 \\
\hline DIV/AT & 0,11 & 0,09 & $-0,10$ & 0,27 & $-0,03$ & 0,04 \\
\hline DIF DIV/AT & 0,10 & 0,07 & $-0,06$ & 0,24 & $-0,04$ & 0,02 \\
\hline$\%$ DIV/AT & 0,13 & 0,13 & 0,14 & $-0,23$ & 0,02 & 0,00 \\
\hline DIV/VM & 0,17 & 0,09 & $-0,06$ & 0,15 & $-0,06$ & 0,05 \\
\hline DIF DIV/VM & 0,16 & 0,12 & 0,04 & 0,12 & 0,03 & 0,03 \\
\hline$\%$ DIV/VM & $-0,01$ & 0,04 & 0,05 & $-0,08$ & 0,05 & 0,01 \\
\hline \multicolumn{7}{|l|}{$\begin{array}{l}\text { DESVIO PADRÃO } \\
\text { VAR. CONT. }\end{array}$} \\
\hline DIV & $-0,04$ & 0,09 & 0,34 & $-0,12$ & 0,35 & $-0,12$ \\
\hline DIF DIV & $-0,05$ & 0,10 & 0,35 & $-0,12$ & 0,29 & $-0,14$ \\
\hline$\%$ DIV & $-0,12$ & $-0,12$ & $-0,10$ & 0,17 & $-0,03$ & $-0,02$ \\
\hline $\mathrm{DIV} / \mathrm{PL}$ & 0,22 & 0,16 & $-0,28$ & 0,03 & 0,30 & 0,17 \\
\hline DIF DIV/PL & 0,21 & 0,15 & $-0,28$ & 0,02 & 0,31 & 0,17 \\
\hline$\%$ DIV/PL & $-0,11$ & $-0,11$ & $-0,10$ & 0,18 & $-0,04$ & $-0,02$ \\
\hline DIV/AT & 0,10 & 0,07 & $-0,08$ & 0,26 & $-0,03$ & 0,03 \\
\hline DIF DIV/AT & 0,09 & 0,05 & $-0,09$ & 0,29 & $-0,01$ & 0,02 \\
\hline$\%$ DIV/AT & $-0,12$ & $-0,11$ & $-0,10$ & 0,18 & $-0,03$ & $-0,02$ \\
\hline DIV/VM & 0,17 & 0,09 & $-0,06$ & 0,14 & $-0,06$ & 0,04 \\
\hline DIF DIV/VM & 0,17 & 0,09 & $-0,05$ & 0,13 & $-0,07$ & 0,03 \\
\hline$\%$ DIV/VM & 0,02 & \begin{tabular}{|l|}
$-0,03$ \\
\end{tabular} & $-0,06$ & 0,11 & $-0,06$ & $-0,01$ \\
\hline
\end{tabular}




\begin{tabular}{|c|c|c|c|c|c|c|}
\hline \multicolumn{7}{|c|}{ CORRELAÇÃO DE PEARSON: ENDIVIDAMENTO } \\
\hline BETA CONTÁBIL & $\begin{array}{l}\text { BM COV } \\
\text { MÉDIO } \\
\end{array}$ & $\begin{array}{l}\text { BM COV } \\
\text { IBOV }\end{array}$ & BM REGR & \begin{tabular}{|l|} 
BM \\
DESALAV \\
ANCADO \\
BRIMBLE \\
\end{tabular} & \begin{tabular}{|l} 
BM \\
DESALAV \\
ANCADO \\
VALLE \\
\end{tabular} & $\begin{array}{l}\text { DESVIO } \\
\text { PADRÃO }\end{array}$ \\
\hline $\mathrm{PC}+\mathrm{ELP}$ & $-0,03$ & 0,09 & 0,35 & $-0,12$ & 0,34 & $-0,12$ \\
\hline DIF PC+ELP & $-0,04$ & 0,07 & 0,30 & $-0,09$ & 0,33 & $-0,11$ \\
\hline$\%$ PC+ELP & $-0,20$ & $-0,24$ & $-0,07$ & $-0,01$ & $-0,07$ & $-0,09$ \\
\hline$P C+E L P / P L$ & 0,06 & $-0,01$ & $-0,23$ & $-0,05$ & 0,17 & 0,08 \\
\hline DIF PC+ELP/PL & $-0,01$ & $-0,09$ & $-0,20$ & $-0,06$ & 0,17 & 0,06 \\
\hline$\% \mathrm{PC}+\mathrm{ELP} / \mathrm{PL}$ & $-0,20$ & $-0,24$ & $-0,08$ & $-0,01$ & $-0,07$ & $-0,09$ \\
\hline $\mathrm{PC}+\mathrm{ELP} / \mathrm{AT}$ & 0,10 & 0,06 & $-0,08$ & 0,25 & $-0,04$ & 0,04 \\
\hline DIF PC+ELP/AT & $-0,05$ & $-0,10$ & $-0,08$ & 0,04 & $-0,07$ & $-0,06$ \\
\hline$\%$ PC+ELP/AT & $-0,20$ & $-0,24$ & $-0,07$ & $-0,01$ & $-0,07$ & $-0,09$ \\
\hline $\mathrm{PC}+\mathrm{ELP} / \mathrm{VM}$ & 0,17 & 0,09 & $-0,05$ & 0,13 & $-0,08$ & 0,04 \\
\hline DIF PC+ELP/VM & 0,16 & 0,09 & $-0,05$ & 0,12 & $-0,07$ & 0,03 \\
\hline$\%$ PC+ELP/VM & $-0,18$ & $-0,22$ & $-0,09$ & 0,01 & $-0,07$ & $-0,09$ \\
\hline \multicolumn{7}{|l|}{ MÉDIA VAR. CONT. } \\
\hline$P C+E L P$ & $-0,04$ & 0,11 & 0,35 & $-0,13$ & 0,31 & $-0,14$ \\
\hline DIF PC+ELP & $-0,04$ & 0,08 & 0,33 & $-0,12$ & 0,34 & $-0,12$ \\
\hline$\% \mathrm{PC}+\mathrm{ELP}$ & $-0,20$ & $-0,24$ & $-0,06$ & $-0,02$ & $-0,08$ & $-0,10$ \\
\hline$P C+E L P / P L$ & 0,14 & 0,09 & $-0,15$ & 0,01 & 0,30 & 0,09 \\
\hline DIF PC+ELP/PL & $-0,11$ & $-0,07$ & $-0,11$ & $-0,10$ & $-0,02$ & 0,01 \\
\hline$\% \mathrm{PC}+\mathrm{ELP} / \mathrm{PL}$ & $-0,20$ & $-0,24$ & $-0,07$ & $-0,01$ & $-0,08$ & $-0,10$ \\
\hline PC+ELP/AT & 0,11 & 0,07 & $-0,10$ & 0,27 & $-0,03$ & 0,04 \\
\hline DIF PC+ELP/AT & 0,10 & 0,08 & $-0,07$ & 0,25 & $-0,04$ & 0,03 \\
\hline$\%$ PC+ELP/AT & $-0,20$ & $-0,23$ & $-0,07$ & $-0,02$ & $-0,08$ & $-0,10$ \\
\hline PC+ELP/VM & 0,17 & 0,08 & $-0,08$ & 0,15 & $-0,07$ & 0,05 \\
\hline DIF PC+ELP/VM & 0,11 & 0,10 & 0,06 & 0,04 & 0,10 & 0,02 \\
\hline$\%$ PC+ELP/VM & $-0,16$ & $-0,20$ & $-0,10$ & 0,04 & $-0,07$ & $-0,08$ \\
\hline \multicolumn{7}{|l|}{$\begin{array}{l}\text { DESVIO PADRÃO } \\
\text { VAR. CONT. }\end{array}$} \\
\hline $\mathrm{PC}+\mathrm{ELP}$ & $-0,03$ & 0,09 & 0,35 & $-0,12$ & 0,34 & $-0,12$ \\
\hline DIF PC+ELP & $-0,04$ & 0,09 & 0,33 & $-0,10$ & 0,30 & $-0,13$ \\
\hline$\%$ PC+ELP & $-0,20$ & $-0,24$ & $-0,07$ & 0,00 & $-0,08$ & $-0,09$ \\
\hline $\mathrm{PC}+\mathrm{ELP} / \mathrm{PL}$ & 0,11 & 0,03 & $-0,34$ & 0,06 & 0,19 & 0,14 \\
\hline DIF PC+ELP/PL & 0,11 & 0,02 & $-0,34$ & 0,05 & 0,21 & 0,14 \\
\hline$\% \mathrm{PC}+\mathrm{ELP} / \mathrm{PL}$ & $-0,21$ & $-0,25$ & $-0,08$ & 0,00 & $-0,07$ & $-0,09$ \\
\hline $\mathrm{PC}+\mathrm{ELP} / \mathrm{AT}$ & 0,10 & 0,06 & $-0,09$ & 0,27 & $-0,05$ & 0,04 \\
\hline DIF PC+ELP/AT & 0,09 & 0,00 & $-0,14$ & 0,28 & $-0,06$ & 0,05 \\
\hline$\%$ PC+ELP/AT & $-0,20$ & $-0,24$ & $-0,07$ & 0,00 & $-0,08$ & $-0,09$ \\
\hline PC+ELP/VM & 0,17 & 0,09 & $-0,05$ & 0,14 & $-0,07$ & 0,04 \\
\hline DIF PC+ELP/VM & 0,16 & 0,08 & $-0,05$ & 0,13 & $-0,07$ & 0,03 \\
\hline$\%$ PC+ELP/VM & $-0,17$ & $-0,21$ & $-0,09$ & 0,03 & $-0,07$ & $-0,09$ \\
\hline
\end{tabular}




\begin{tabular}{|c|c|c|c|c|c|c|}
\hline & & Trist & (1) & CAGEM & ANCEIRA & \\
\hline BETA CONTÁBIL & $\begin{array}{l}\text { BM COV } \\
\text { MÉDIO }\end{array}$ & $\begin{array}{l}\text { BM COV } \\
\text { IBOV }\end{array}$ & BM REGR & \begin{tabular}{|l|} 
BM \\
DESALAV \\
ANCADO \\
BRIMBLE \\
\end{tabular} & \begin{tabular}{|l|} 
BM \\
DESALAV \\
ANCADO \\
VALLE \\
\end{tabular} & $\begin{array}{l}\text { DESVIO } \\
\text { PADRÃO }\end{array}$ \\
\hline GAF & 0,00 & 0,09 & 0,12 & $-0,07$ & $-0,03$ & $-0,05$ \\
\hline DIF GAF & 0,00 & 0,09 & 0,12 & $-0,07$ & $-0,03$ & $-0,05$ \\
\hline$\%$ GAF & $-0,06$ & 0,06 & 0,03 & $-0,10$ & 0,01 & $-0,04$ \\
\hline GAF/PL & $-0,16$ & $-0,15$ & $-0,20$ & $-0,10$ & $-0,08$ & 0,03 \\
\hline DIF GAF/PL & $-0,16$ & $-0,15$ & $-0,21$ & $-0,09$ & $-0,08$ & 0,03 \\
\hline$\% \mathrm{GAF} / \mathrm{PL}$ & $-0,07$ & 0,05 & 0,00 & $-0,10$ & 0,01 & $-0,04$ \\
\hline GAF/AT & $-0,11$ & $-0,10$ & $-0,18$ & 0,35 & $-0,07$ & 0,00 \\
\hline DIF GAF/AT & $-0,08$ & $-0,06$ & $-0,15$ & 0,36 & $-0,07$ & $-0,01$ \\
\hline$\%$ GAF/AT & $-0,05$ & 0,07 & 0,06 & $-0,10$ & 0,00 & $-0,05$ \\
\hline GAF/VM & 0,15 & 0,07 & $-0,06$ & 0,14 & $-0,08$ & 0,03 \\
\hline DIF GAF/VM & 0,16 & 0,09 & $-0,05$ & 0,13 & $-0,07$ & 0,02 \\
\hline$\%$ GAF/VM & $-0,08$ & $-0,07$ & $-0,07$ & 0,26 & $-0,02$ & $-0,02$ \\
\hline \multicolumn{7}{|l|}{ MÉDIA VAR. CONT. } \\
\hline GAF & 0,00 & $-0,09$ & $-0,13$ & 0,07 & 0,03 & 0,06 \\
\hline DIF GAF & 0,00 & 0,09 & 0,12 & $-0,07$ & $-0,03$ & $-0,05$ \\
\hline$\% \mathrm{GAF}$ & 0,05 & $-0,07$ & $-0,05$ & 0,11 & $-0,11$ & 0,03 \\
\hline GAF/PL & 0,08 & 0,05 & 0,04 & 0,20 & 0,02 & 0,03 \\
\hline DIF GAF/PL & 0,02 & 0,11 & 0,09 & $-0,17$ & 0,00 & $-0,04$ \\
\hline$\% \mathrm{GAF} / \mathrm{PL}$ & 0,05 & $-0,06$ & $-0,02$ & 0,10 & $-0,10$ & 0,02 \\
\hline GAF/AT & 0,21 & 0,17 & 0,13 & 0,00 & 0,06 & 0,05 \\
\hline DIF GAF/AT & $-0,01$ & 0,08 & 0,07 & $-0,04$ & $-0,01$ & $-0,04$ \\
\hline$\%$ GAF/AT & 0,05 & $-0,08$ & $-0,08$ & 0,12 & $-0,12$ & 0,04 \\
\hline GAF/VM & 0,18 & 0,11 & 0,02 & 0,14 & $-0,04$ & 0,00 \\
\hline DIF GAF/VM & $-0,05$ & $-0,08$ & $-0,06$ & 0,19 & $-0,01$ & $-0,01$ \\
\hline$\%$ GAF/VM & 0,09 & 0,05 & 0,04 & $-0,08$ & 0,18 & 0,04 \\
\hline \multicolumn{7}{|l|}{$\begin{array}{l}\text { DESVIO PADRÃO } \\
\text { VAR. CONT. }\end{array}$} \\
\hline GAF & $-0,03$ & 0,09 & 0,35 & $-0,12$ & 0,34 & $-0,12$ \\
\hline DIF GAF & $-0,04$ & 0,09 & 0,33 & $-0,10$ & 0,30 & $-0,13$ \\
\hline$\%$ GAF & $-0,20$ & $-0,24$ & $-0,07$ & 0,00 & $-0,08$ & $-0,09$ \\
\hline GAF/PL & 0,11 & 0,03 & $-0,34$ & 0,06 & 0,19 & 0,14 \\
\hline DIF GAF/PL & 0,11 & 0,02 & $-0,34$ & 0,05 & 0,21 & 0,14 \\
\hline$\% \mathrm{GAF} / \mathrm{PL}$ & $-0,21$ & $-0,25$ & $-0,08$ & 0,00 & $-0,07$ & $-0,09$ \\
\hline GAF/AT & 0,10 & 0,06 & $-0,09$ & 0,27 & $-0,05$ & 0,04 \\
\hline DIF GAF/AT & 0,09 & 0,00 & $-0,14$ & 0,28 & $-0,06$ & 0,05 \\
\hline$\%$ GAF/AT & $-0,20$ & $-0,24$ & $-0,07$ & 0,00 & $-0,08$ & $-0,09$ \\
\hline GAF/VM & 0,17 & 0,09 & $-0,05$ & 0,14 & $-0,07$ & 0,04 \\
\hline DIF GAF/VM & 0,16 & 0,08 & $-0,05$ & 0,13 & $-0,07$ & 0,03 \\
\hline$\%$ GAF/VM & $-0,17$ & $-0,21$ & $-0,09$ & 0,03 & $-0,07$ & $-0,09$ \\
\hline
\end{tabular}




\begin{tabular}{|c|c|c|c|c|c|c|}
\hline \multicolumn{7}{|c|}{ CORRELAÇÃO DE PEARSON: GRAU DE ALAVANCAGEM OPERACIONAL } \\
\hline BETA CONTÁBIL & $\begin{array}{l}\text { BM COV } \\
\text { MÉDIO }\end{array}$ & $\begin{array}{l}\text { BM COV } \\
\text { IBOV }\end{array}$ & BM REGR & \begin{tabular}{|l|} 
BM \\
DESALAV \\
ANCADO \\
BRIMBLE \\
\end{tabular} & \begin{tabular}{|l|} 
BM \\
DESALAV \\
ANCADO \\
VALLE \\
\end{tabular} & $\begin{array}{l}\text { DESVIO } \\
\text { PADRÃO }\end{array}$ \\
\hline GAO & 0,12 & 0,11 & $-0,08$ & $-0,02$ & $-0,05$ & 0,02 \\
\hline DIF GAO & 0,13 & 0,13 & $-0,07$ & $-0,02$ & $-0,04$ & 0,03 \\
\hline$\% \mathrm{GAO}$ & 0,15 & 0,15 & $-0,05$ & $-0,02$ & $-0,04$ & 0,03 \\
\hline $\mathrm{GAO} / \mathrm{PL}$ & 0,12 & 0,13 & $-0,10$ & $-0,03$ & $-0,04$ & 0,03 \\
\hline DIF GAO/PL & 0,12 & 0,13 & $-0,10$ & $-0,02$ & $-0,04$ & 0,04 \\
\hline$\% \mathrm{GAO} / \mathrm{PL}$ & 0,15 & 0,15 & $-0,05$ & $-0,02$ & $-0,04$ & 0,03 \\
\hline GAO/AT & 0,10 & 0,07 & $-0,07$ & 0,24 & $-0,04$ & 0,03 \\
\hline DIF GAO/AT & 0,10 & 0,07 & $-0,07$ & 0,24 & $-0,04$ & 0,03 \\
\hline$\%$ GAO/AT & 0,15 & 0,15 & $-0,05$ & $-0,02$ & $-0,04$ & 0,03 \\
\hline GAO/VM & 0,05 & 0,06 & 0,00 & 0,36 & $-0,03$ & $-0,02$ \\
\hline DIF GAO/VM & 0,05 & 0,06 & $-0,01$ & 0,35 & $-0,03$ & $-0,02$ \\
\hline$\% \mathrm{GAO} / \mathrm{VM}$ & 0,05 & 0,10 & 0,04 & $-0,03$ & $-0,04$ & $-0,03$ \\
\hline \multicolumn{7}{|c|}{ MÉDIA VAR. CONT. } \\
\hline GAO & 0,17 & 0,20 & 0,01 & 0,00 & $-0,04$ & 0,03 \\
\hline DIF GAO & 0,14 & 0,20 & 0,10 & $-0,06$ & $-0,01$ & 0,03 \\
\hline$\% \mathrm{GAO}$ & 0,14 & 0,15 & $-0,07$ & 0,01 & $-0,03$ & 0,04 \\
\hline $\mathrm{GAO} / \mathrm{PL}$ & 0,11 & 0,14 & $-0,09$ & $-0,06$ & $-0,02$ & 0,03 \\
\hline DIF GAO/PL & $-0,07$ & $-0,01$ & $-0,02$ & $-0,02$ & $-0,13$ & 0,00 \\
\hline$\% \mathrm{GAO} / \mathrm{PL}$ & 0,14 & 0,14 & $-0,07$ & 0,01 & $-0,03$ & 0,04 \\
\hline GAO/AT & 0,11 & 0,08 & $-0,07$ & 0,24 & $-0,04$ & 0,03 \\
\hline DIF GAO/AT & 0,10 & 0,07 & $-0,07$ & 0,23 & $-0,04$ & 0,03 \\
\hline$\%$ GAO/AT & 0,14 & 0,15 & $-0,07$ & 0,00 & $-0,03$ & 0,04 \\
\hline GAO/VM & 0,00 & 0,04 & $-0,03$ & 0,25 & 0,06 & 0,01 \\
\hline DIF GAO/VM & 0,04 & 0,05 & $-0,05$ & $-0,03$ & 0,07 & 0,05 \\
\hline$\% \mathrm{GAO} / \mathrm{VM}$ & 0,05 & 0,13 & 0,01 & $-0,08$ & $-0,01$ & $-0,05$ \\
\hline \multicolumn{7}{|l|}{$\begin{array}{l}\text { DESVIO PADRÃO } \\
\text { VAR. CONT. }\end{array}$} \\
\hline GAO & 0,05 & 0,09 & $-0,01$ & $-0,02$ & $-0,08$ & $-0,03$ \\
\hline DIF GAO & 0,06 & 0,10 & 0,00 & $-0,02$ & $-0,07$ & $-0,03$ \\
\hline$\% \mathrm{GAO}$ & 0,16 & 0,16 & $-0,05$ & 0,00 & $-0,06$ & 0,02 \\
\hline $\mathrm{GAO} / \mathrm{PL}$ & 0,07 & 0,07 & $-0,16$ & 0,00 & $-0,04$ & 0,03 \\
\hline DIF GAO/PL & 0,07 & 0,07 & $-0,16$ & 0,00 & $-0,04$ & 0,03 \\
\hline$\% \mathrm{GAO} / \mathrm{PL}$ & 0,16 & 0,16 & $-0,05$ & 0,00 & $-0,06$ & 0,02 \\
\hline GAO/AT & 0,10 & 0,07 & $-0,07$ & 0,24 & $-0,04$ & 0,03 \\
\hline DIF GAO/AT & 0,10 & 0,07 & $-0,07$ & 0,24 & $-0,04$ & 0,03 \\
\hline$\%$ GAO/AT & 0,16 & 0,16 & $-0,05$ & 0,01 & $-0,06$ & 0,02 \\
\hline GAO/VM & 0,03 & 0,05 & $-0,01$ & 0,35 & $-0,03$ & $-0,03$ \\
\hline DIF GAO/VM & 0,03 & 0,05 & $-0,01$ & 0,35 & $-0,03$ & $-0,03$ \\
\hline$\% \mathrm{GAO} / \mathrm{VM}$ & 0,06 & 0,08 & 0,02 & 0,07 & $-0,06$ & 0,02 \\
\hline
\end{tabular}


CORRELAÇÃO DE PEARSON: COBERTURA DE JUROS

\begin{tabular}{|c|c|c|c|c|c|c|}
\hline BETA CONTÁBIL & $\begin{array}{l}\text { BM COV } \\
\text { MÉDIO }\end{array}$ & $\begin{array}{l}\text { BM COV } \\
\text { IBOV }\end{array}$ & BM REGR & \begin{tabular}{|l|} 
BM \\
DESALAV \\
ANCADO \\
BRIMBLE \\
\end{tabular} & \begin{tabular}{|l} 
BM \\
DESALAV \\
ANCADO \\
VALLE
\end{tabular} & $\begin{array}{l}\text { DESVIO } \\
\text { PADRÃO }\end{array}$ \\
\hline COB JUR & $-0,21$ & $-0,20$ & 0,03 & \begin{tabular}{|r|}
0,14 \\
\end{tabular} & \begin{tabular}{|r|}
$-0,08$ \\
\end{tabular} & $-0,11$ \\
\hline DIF COB JUR & $-0,16$ & $-0,14$ & 0,07 & 0,16 & $-0,07$ & $-0,10$ \\
\hline$\%$ COB JUR & $-0,11$ & $-0,14$ & $-0,05$ & 0,01 & $-0,04$ & $-0,04$ \\
\hline COB JUR/PL & $-0,12$ & $-0,10$ & 0,07 & 0,20 & $-0,05$ & $-0,07$ \\
\hline DIF COB JUR/PL & $-0,12$ & $-0,09$ & 0,09 & 0,18 & $-0,05$ & $-0,07$ \\
\hline$\%$ COB JUR/PL & $-0,11$ & $-0,14$ & $-0,05$ & 0,01 & $-0,04$ & $-0,04$ \\
\hline COB JUR/AT & $-0,12$ & $-0,09$ & 0,09 & 0,18 & $-0,05$ & $-0,07$ \\
\hline DIF COB JUR/AT & $-0,11$ & $-0,08$ & 0,09 & 0,17 & $-0,05$ & $-0,07$ \\
\hline$\%$ COB JUR/AT & $-0,11$ & $-0,14$ & $-0,05$ & 0,01 & $-0,04$ & $-0,04$ \\
\hline COB JUR/VM & $-0,02$ & $-0,05$ & $-0,01$ & 0,04 & $-0,06$ & $-0,03$ \\
\hline DIF COB JUR/VM & $-0,02$ & $-0,04$ & 0,00 & 0,04 & $-0,06$ & $-0,03$ \\
\hline$\%$ COB JUR/VM & $-0,16$ & $-0,16$ & $-0,18$ & 0,31 & 0,52 & 0,00 \\
\hline \multicolumn{7}{|l|}{ MÉDIA VAR. CONT. } \\
\hline COB JUR & $-0,19$ & $-0,21$ & 0,02 & 0,00 & $-0,07$ & $-0,12$ \\
\hline DIF COB JUR & $-0,12$ & $-0,12$ & $-0,16$ & 0,25 & $-0,05$ & 0,03 \\
\hline$\%$ COB JUR & $-0,11$ & $-0,14$ & $-0,05$ & 0,01 & $-0,04$ & $-0,05$ \\
\hline COB JUR/PL & $-0,09$ & $-0,06$ & 0,15 & 0,04 & $-0,04$ & $-0,10$ \\
\hline DIF COB JUR/PL & $-0,12$ & $-0,12$ & $-0,16$ & 0,25 & $-0,05$ & 0,03 \\
\hline$\%$ COB JUR/PL & $-0,11$ & $-0,14$ & $-0,05$ & 0,01 & $-0,04$ & $-0,05$ \\
\hline COB JUR/AT & $-0,12$ & $-0,10$ & 0,12 & 0,08 & $-0,05$ & $-0,11$ \\
\hline DIF COB JUR/AT & $-0,12$ & $-0,12$ & $-0,17$ & 0,25 & $-0,05$ & 0,03 \\
\hline$\%$ COB JUR/AT & $-0,11$ & $-0,14$ & $-0,05$ & 0,01 & $-0,04$ & $-0,04$ \\
\hline COB JUR/VM & $-0,02$ & 0,05 & 0,04 & 0,00 & 0,03 & $-0,03$ \\
\hline DIF COB JUR/VM & $-0,01$ & $-0,07$ & $-0,04$ & 0,05 & $-0,04$ & $-0,01$ \\
\hline$\%$ COB JUR/VM & $-0,16$ & $-0,16$ & $-0,18$ & 0,32 & 0,52 & 0,00 \\
\hline \multicolumn{7}{|l|}{$\begin{array}{l}\text { DESVIO PADRÃO } \\
\text { VAR. CONT. }\end{array}$} \\
\hline COB JUR & $-0,23$ & $-0,23$ & 0,01 & 0,15 & $-0,10$ & $-0,12$ \\
\hline DIF COB JUR & $-0,20$ & $-0,20$ & 0,04 & 0,17 & $-0,09$ & $-0,11$ \\
\hline$\%$ COB JUR & $-0,11$ & $-0,14$ & $-0,05$ & 0,01 & $-0,04$ & $-0,05$ \\
\hline COB JUR/PL & $-0,16$ & $-0,14$ & 0,02 & 0,24 & $-0,07$ & $-0,06$ \\
\hline DIF COB JUR/PL & $-0,14$ & $-0,12$ & 0,04 & 0,23 & $-0,06$ & $-0,06$ \\
\hline$\%$ COB JUR/PL & $-0,11$ & $-0,14$ & $-0,05$ & 0,01 & $-0,04$ & $-0,05$ \\
\hline COB JUR/AT & $-0,15$ & $-0,13$ & 0,05 & 0,22 & $-0,07$ & $-0,07$ \\
\hline DIF COB JUR/AT & $-0,14$ & $-0,12$ & 0,06 & 0,21 & $-0,06$ & $-0,07$ \\
\hline$\%$ COB JUR/AT & $-0,11$ & $-0,14$ & $-0,05$ & 0,01 & $-0,04$ & $-0,05$ \\
\hline COB JUR/VM & $-0,02$ & $-0,04$ & $-0,01$ & 0,06 & $-0,06$ & $-0,04$ \\
\hline DIF COB JUR/VM & $-0,02$ & $-0,03$ & 0,00 & 0,06 & $-0,05$ & $-0,04$ \\
\hline$\%$ COB JUR/VM & $-0,16$ & $-0,16$ & $-0,18$ & 0,32 & 0,52 & 0,00 \\
\hline
\end{tabular}




\begin{tabular}{|c|c|c|c|c|c|c|}
\hline \multicolumn{7}{|c|}{ CORRELAÇÃO DE PEARSON: TAMANHO DO ATIVO } \\
\hline BETA CONTÁBIL & $\begin{array}{l}\text { BM COV } \\
\text { MÉDIO }\end{array}$ & $\begin{array}{l}\text { BM COV } \\
\text { IBOV }\end{array}$ & BM REGR & \begin{tabular}{|l} 
BM \\
DESALAV \\
ANCADO \\
BRIMBLE \\
\end{tabular} & $\begin{array}{l}\text { BM } \\
\text { DESALAV } \\
\text { ANCADO } \\
\text { VALLE }\end{array}$ & $\begin{array}{l}\text { DESVIO } \\
\text { PADRÃO }\end{array}$ \\
\hline $\mathrm{BC} 1$ & $-0,09$ & $-0,14$ & $-0,11$ & 0,02 & \begin{tabular}{|l|}
0,01 \\
\end{tabular} & $-0,02$ \\
\hline BC2 & $-0,09$ & $-0,15$ & $-0,11$ & 0,01 & 0,01 & $-0,02$ \\
\hline $\mathrm{BC} 3$ & 0,01 & 0,00 & $-0,04$ & $-0,04$ & $-0,05$ & 0,00 \\
\hline VC1 & $-0,09$ & 0,09 & 0,39 & $-0,42$ & 0,07 & $-0,25$ \\
\hline VC2 & 0,08 & 0,01 & 0,02 & $-0,17$ & $-0,10$ & 0,05 \\
\hline VC3 & $-0,05$ & 0,00 & 0,04 & 0,06 & 0,05 & $-0,04$ \\
\hline DS1 & $-0,03$ & $-0,14$ & $-0,17$ & 0,15 & $-0,01$ & 0,05 \\
\hline DS2 & $-0,04$ & $-0,15$ & $-0,16$ & 0,13 & 0,00 & 0,05 \\
\hline DS3 & 0,01 & $-0,03$ & $-0,07$ & $-0,06$ & $-0,06$ & 0,03 \\
\hline
\end{tabular}

\begin{tabular}{|c|c|c|c|c|c|c|}
\hline \multicolumn{7}{|c|}{ CORRELAÇÃO DE PEARSON: LPA } \\
\hline BETA CONTÁBIL & $\begin{array}{l}\text { BM COV } \\
\text { MÉDIO }\end{array}$ & $\begin{array}{l}\text { BM COV } \\
\text { IBOV }\end{array}$ & BM REGR & \begin{tabular}{|l|} 
BM \\
DESALAV \\
ANCADO \\
BRIMBLE \\
\end{tabular} & $\begin{array}{l}\text { BM } \\
\text { DESALAV } \\
\text { ANCADO } \\
\text { VALLE } \\
\end{array}$ & $\begin{array}{l}\text { DESVIO } \\
\text { PADRÃOO }\end{array}$ \\
\hline BC1 & 0,01 & $-0,07$ & $-0,18$ & 0,04 & $-0,10$ & 0,04 \\
\hline $\mathrm{BC2}$ & 0,04 & $-0,05$ & $-0,16$ & 0,06 & $-0,10$ & 0,03 \\
\hline $\mathrm{BC3}$ & 0,10 & 0,07 & $-0,07$ & 0,24 & $-0,04$ & 0,03 \\
\hline $\mathrm{VC1}$ & 0,15 & 0,17 & 0,21 & 0,07 & 0,07 & $-0,03$ \\
\hline VC2 & $-0,14$ & $-0,11$ & $-0,17$ & $-0,11$ & $-0,07$ & 0,03 \\
\hline VC3 & 0,10 & 0,07 & $-0,06$ & 0,21 & $-0,04$ & 0,03 \\
\hline DS1 & 0,03 & $-0,07$ & $-0,19$ & 0,08 & $-0,10$ & 0,05 \\
\hline DS2 & 0,03 & $-0,07$ & $-0,19$ & 0,07 & $-0,10$ & 0,05 \\
\hline DS3 & 0,10 & 0,07 & $-0,07$ & 0,26 & $-0,04$ & 0,03 \\
\hline
\end{tabular}

\begin{tabular}{|c|c|c|c|c|c|c|}
\hline \multicolumn{7}{|c|}{ CORRELAÇÃO DE PEARSON: CRESCIMENTO DO ATIVO } \\
\hline BETA CONTÁBIL & $\begin{array}{l}\text { BM COV } \\
\text { MÉDIO }\end{array}$ & $\begin{array}{l}\text { BM COV } \\
\text { IBOV }\end{array}$ & BM REGR & $\begin{array}{l}\text { BM } \\
\text { DESALAV } \\
\text { ANCADO } \\
\text { BRIMBLE }\end{array}$ & $\begin{array}{l}\text { BM } \\
\text { DESALAV } \\
\text { ANCADO } \\
\text { VALLE }\end{array}$ & $\begin{array}{l}\text { DESVIO } \\
\text { PADRÃO }\end{array}$ \\
\hline $\mathrm{BC} 1$ & $-0,06$ & $-0,12$ & $-0,10$ & 0,03 & $-0,04$ & $-0,04$ \\
\hline $\mathrm{BC2}$ & $-0,06$ & $-0,13$ & $-0,10$ & 0,03 & $-0,04$ & $-0,03$ \\
\hline $\mathrm{BC} 3$ & $-0,02$ & $-0,03$ & $-0,02$ & $-0,05$ & $-0,06$ & $-0,02$ \\
\hline VC1 & $-0,09$ & $-0,15$ & $-0,06$ & 0,01 & $-0,06$ & $-0,05$ \\
\hline $\mathrm{VC2}$ & 0,04 & $-0,03$ & 0,00 & $-0,13$ & $-0,09$ & 0,03 \\
\hline VC3 & $-0,07$ & $-0,02$ & 0,02 & 0,06 & 0,05 & $-0,05$ \\
\hline DS1 & 0,02 & $-0,09$ & $-0,13$ & 0,14 & $-0,05$ & 0,03 \\
\hline DS2 & 0,01 & $-0,10$ & $-0,13$ & 0,13 & $-0,04$ & 0,03 \\
\hline DS3 & $-0,02$ & $-0,08$ & $-0,06$ & $-0,06$ & $-0,07$ & 0,01 \\
\hline
\end{tabular}




\begin{tabular}{|c|c|c|c|c|c|}
\hline \multicolumn{6}{|c|}{ Teste de Hausmann } \\
\hline \multirow[t]{9}{*}{ tabela 4} & \multirow{3}{*}{$\begin{array}{l}1 \text { a } 56 \\
\text { ao nível }\end{array}$} & \multicolumn{4}{|c|}{ Correlated Random Effects - Hausman Test } \\
\hline & & Pool: DADOS & & & \\
\hline & & \multicolumn{2}{|c|}{ Test cross-section random effects } & & \\
\hline & & & & \multirow{2}{*}{\multicolumn{2}{|c|}{ Chi-Sq. d.f Prob. }} \\
\hline & & Test Summary & Chi-Sq. Statistic & & \\
\hline & & & & & \\
\hline & & Cross-section random & 48.400 .343 & 27 & 0.0069 \\
\hline & & & & & \\
\hline & \multicolumn{2}{|c|}{ 40,11 maior rejeita Ho de } & que o efeito alea & atório é o n & melhor \\
\hline \multirow[t]{8}{*}{ tabela 5} & 36 a 56 & \multicolumn{4}{|c|}{ Correlated Random Effects - Hausman Test } \\
\hline & ao nível & Pool: DADOS & & & \\
\hline & & \multicolumn{2}{|c|}{ Test cross-section random effects } & & \\
\hline & & Test Summary & Chi-Sa Statistic & \multirow{2}{*}{\multicolumn{2}{|c|}{ Chi-Sq. d.f Prob. }} \\
\hline & & & 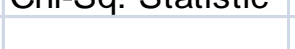 & & \\
\hline & & Cross-section random & 65.185 .161 & 27 & 0.0001 \\
\hline & & & & & \\
\hline & \multicolumn{2}{|c|}{ 40,11 maior rejeita Ho de } & que o efeito alea & atório é o n & melhor \\
\hline \multirow[t]{8}{*}{ tabela 6} & 36 a 56 & \multicolumn{4}{|c|}{ Correlated Random Effects - Hausman Test } \\
\hline & $(+1)$ & Pool: DADOS & & & \\
\hline & & \multicolumn{2}{|c|}{ Test cross-section random effects } & & \\
\hline & & & & & \\
\hline & & Test Summary & Chi-Sq. Statistic & \multicolumn{2}{|c|}{ Chi-Sq. d.f Prob. } \\
\hline & & & & & \\
\hline & & \multirow{2}{*}{\multicolumn{4}{|c|}{$\begin{array}{lll}\text { Cross-section random } & 75.725 .187 & 27 \\
\text { maior rejeita Ho de que o efeito aleatório é o melhor }\end{array}$}} \\
\hline & 40, & & & & \\
\hline \multirow[t]{8}{*}{ tabela 7} & 36 a 56 & Correlated Random Ef & ffects - Hausman T & Test & \\
\hline & $(+4)$ & Pool: DADOS & & & \\
\hline & & Test cross-section ran & ndom effects & & \\
\hline & & & & & \\
\hline & & Test Summary & Chi-Sq. Statistic & Chi-Sq. d.f & Prob. \\
\hline & & & & & \\
\hline & & Cross-section random & 129.866 .238 & 27 & 0.0000 \\
\hline & 40, & maior rejeita Ho de & que o efeito alea & atório é o $n$ & melhor \\
\hline tabela 9 & 36 a 56 & Correlated Random Ef & ffects - Hausman T & Test & \\
\hline & BMT (-1) & Pool: DADOS & & & \\
\hline & & Test cross-section ran & ndom effects & & \\
\hline & & Test Summary & Chi-Sq. Statistic & Chi-Sq. d.f & Prob. \\
\hline & & & & & \\
\hline & & Cross-section random & 115.700 .170 & 28 & 0.0000 \\
\hline
\end{tabular}




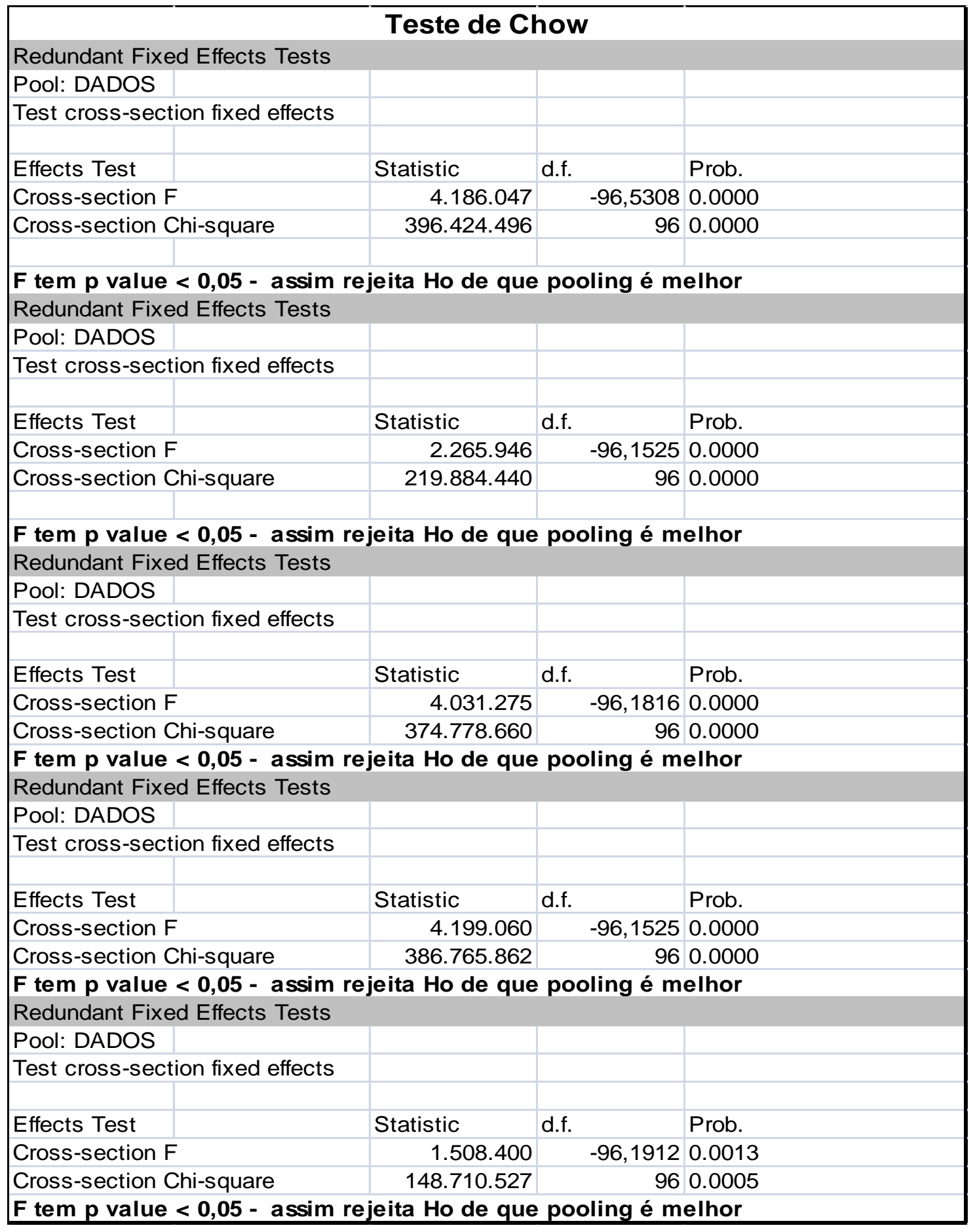


TESTE DE CO-INTEGRAÇÃO

Pedroni Residual Cointegration Test

Series: BMT? CMTB? ENDPL? GAF? GAO? LAIRAT? LIQ?

Date: 04/28/10 Time: 20:56

Sample: 156

Included observations: 56

Cross-sections included: 97

Null Hypothesis: No cointegration

Trend assumption: No deterministic trend

User-specified lag length: 1

User-specified bandwidth: 2 and Bartlett kernel

Alternative hypothesis: common AR coefs. (within-dimension)

\begin{tabular}{|l|c|l|r|l|}
\hline & & \multicolumn{3}{|c|}{ Weighted } \\
\hline Panel v-Statistic & 6.965 .574 & 0.0000 & 7.083 .093 & 0.0000 \\
\hline Panel rho-Statistic & -6.690 .504 & 0.0000 & -6.906 .730 & 0.0000 \\
\hline Panel PP-Statistic & -1.666 .239 & 0.0000 & -1.537 .709 & 0.0000 \\
\hline Panel ADF-Statistic & -5.455 .070 & 0.0000 & -5.110 .109 & 0.0000 \\
\hline
\end{tabular}

Alternative hypothesis: individual AR coefs. (between-dimension)

\begin{tabular}{|l|l|l|l|l|}
\hline & & & \\
\hline & Statistic & Prob. & \\
\hline Group rho-Statistic & -5.329 .167 & 0.0000 & \\
\hline Group PP-Statistic & -1.689 .423 & 0.0000 & \\
\hline Group ADF-Statistic & -5.727 .226 & 0.0000 & \\
\hline
\end{tabular}

TESTE DE CO-INTEGRAÇÃO

Pedroni Residual Cointegration Test

Series: BMT? CLPA? CMTB? END? DIV?

Date: 04/28/10 Time: 21:01

Sample: 156

Included observations: 56

Cross-sections included: 97

Null Hypothesis: No cointegration

Trend assumption: No deterministic trend

User-specified lag length: 1

User-specified bandwidth: 2 and Bartlett kernel

Alternative hypothesis: common AR coefs. (within-dimension)

\begin{tabular}{|l|r|l|r|l|}
\hline & & \multicolumn{3}{|l|}{ Weighted } \\
\hline & Statistic & Prob. & Statistic & Prob. \\
\hline Panel v-Statistic & 1.363 .845 & 0.0000 & 1.238 .091 & 0.0000 \\
\hline Panel rho-Statistic & -1.496 .902 & 0.0000 & -1.252 .151 & 0.0000 \\
\hline Panel PP-Statistic & -2.194 .488 & 0.0000 & -1.734 .290 & 0.0000 \\
\hline Panel ADF-Statistic & -1.646 .933 & 0.0000 & -1.019 .031 & 0.0000 \\
\hline
\end{tabular}

Alternative hypothesis: individual AR coefs. (between-dimensio

\begin{tabular}{|l|l|l|l|l|}
\hline & & & \\
\hline & Statistic & Prob. & & \\
\hline Group rho-Statistic & -1.182 .514 & 0.0000 & \\
\hline Group PP-Statistic & -1.995 .445 & 0.0000 & \\
\hline Group ADF-Statistic & -1.292 .838 & 0.0000 & \\
\hline
\end{tabular}


TESTE DE CO-INTEGRAÇÃO

Pedroni Residual Cointegration Test

Series: BMT? CMTB? LAIR? LIQ?

Date: 04/28/10 Time: 21:07

Sample: 156

Included observations: 56

Cross-sections included: 97

Null Hypothesis: No cointegration

Trend assumption: No deterministic trend

User-specified lag length: 1

User-specified bandwidth: 2 and Bartlett kernel

Alternative hypothesis: common AR coefs. (within-dimension)

\begin{tabular}{|l|r|l|r|l|}
\hline & & \multicolumn{3}{c|}{ Weighted } \\
\hline & Statistic & Prob. & Statistic & Prob. \\
\hline Panel v-Statistic & 1.505 .175 & 0.0000 & 1.692 .097 & 0.0000 \\
\hline Panel rho-Statistic & -1.542 .551 & 0.0000 & -1.785 .358 & 0.0000 \\
\hline Panel PP-Statistic & -2.078 .852 & 0.0000 & -2.024 .430 & 0.0000 \\
\hline Panel ADF-Statistic & -2.055 .308 & 0.0000 & -1.377 .081 & 0.0000 \\
\hline
\end{tabular}

Alternative hypothesis: individual AR coefs. (between-dimensio

\begin{tabular}{|l|l|l|l|l|}
\hline \multicolumn{3}{|c|}{ Alternative hypothesis: individual AR coefs. (between-dimensio } \\
\hline & Statistic & Prob. & \\
\hline Group rho-Statistic & -1.723 .632 & 0.0000 & \\
\hline Group PP-Statistic & -2.370 .927 & 0.0000 & \\
\hline Group ADF-Statistic & -1.728 .401 & 0.0000 & \\
\hline
\end{tabular}




\begin{tabular}{|c|c|c|c|c|c|}
\hline \multirow[t]{2}{*}{ Communalities } & \multicolumn{2}{|c|}{$\%$ MTB } & \multirow{2}{*}{$\begin{array}{l}\text { VAR00049 } \\
\text { n VAR00050 }\end{array}$} & \multirow{2}{*}{$\begin{array}{l}1 \\
1\end{array}$} & \multirow{2}{*}{$\begin{array}{l}0,980596 \\
0,979687\end{array}$} \\
\hline & Initial & Extraction & & & \\
\hline VAR00001 & 1 & 0,96379 & VAR00051 & 1 & 0,932529 \\
\hline VAR00002 & 1 & 0,959804 & VAR00052 & 1 & 0,897894 \\
\hline VAR00003 & 1 & 0,906227 & VAR00053 & 1 & 0,911579 \\
\hline VAR00004 & 1 & 0,991891 & VAR00054 & 1 & 0,972924 \\
\hline VAR00005 & 1 & 0,813044 & VAR00055 & 1 & 0,791929 \\
\hline VAR00006 & 1 & 0,976478 & VAR00056 & 1 & 0,925916 \\
\hline VAR00007 & 1 & 0,891663 & VAR00057 & 1 & 0,994139 \\
\hline VAR00008 & 1 & 0,802386 & VAR00058 & 1 & 0,939359 \\
\hline VAR00009 & 1 & 0,922779 & VAR00059 & 1 & 0,9436 \\
\hline VAR00010 & 1 & 0,82449 & VAR00060 & 1 & 0,922314 \\
\hline VAR00011 & 1 & 0,973636 & VAR00061 & 1 & 0,985496 \\
\hline VAR00012 & 1 & 0,966114 & VAR00062 & 1 & 0,840256 \\
\hline VAR00013 & 1 & 0,963068 & VAR00063 & 1 & 0,935161 \\
\hline VAR00014 & 1 & 0,986924 & VAR00064 & 1 & 0,944474 \\
\hline VAR00015 & 1 & 0,982585 & VAR00065 & 1 & 0,920934 \\
\hline VAR00016 & 1 & 0,972628 & VAR00066 & 1 & 0,984831 \\
\hline VAR00017 & 1 & 0,970016 & VAR00067 & 1 & 0,674486 \\
\hline VAR00018 & 1 & 0,863566 & VAR00068 & 1 & 0,956196 \\
\hline VAR00019 & 1 & 0,807852 & VAR00069 & 1 & 0,927415 \\
\hline VAR00020 & 1 & 0,986832 & VAR00070 & 1 & 0,98049 \\
\hline VAR00021 & 1 & 0,929666 & VAR00071 & 1 & 0,918875 \\
\hline VAR00022 & 1 & 0,946704 & VAR00072 & 1 & 0,976936 \\
\hline VAR00023 & 1 & 0,954261 & VAR00073 & 1 & 0,874964 \\
\hline VAR00024 & 1 & 0,744365 & VAR00074 & 1 & 0,953567 \\
\hline VAR00025 & 1 & 0,983677 & VAR00075 & 1 & 0,974849 \\
\hline VAR00026 & 1 & 0,988228 & VAR00076 & 1 & 0,971363 \\
\hline VAR00027 & 1 & 0,891328 & VAR00077 & 1 & 0,824636 \\
\hline VAR00028 & 1 & 0,900942 & VAR00078 & 1 & 0,95352 \\
\hline VAR00029 & 1 & 0,973283 & VAR00079 & 1 & 0,765334 \\
\hline VAR00030 & 1 & 0,929246 & VAR00080 & 1 & 0,828925 \\
\hline VAR00031 & 1 & 0,728993 & VAR00081 & 1 & 0,923828 \\
\hline VAR00032 & 1 & 0,841389 & VAR00082 & 1 & 0,913823 \\
\hline VAR00033 & 1 & 0,970536 & VAR00083 & 1 & 0,949109 \\
\hline VAR00034 & 1 & 0,950587 & VAR00084 & 1 & 0,987018 \\
\hline VAR00035 & 1 & 0,967838 & VAR00085 & 1 & 0,873195 \\
\hline VAR00036 & 1 & 0,932638 & VAR00086 & 1 & 0,986062 \\
\hline VAR00037 & 1 & 0,95391 & VAR00087 & 1 & 0,991232 \\
\hline VAR00038 & 1 & 0,978998 & VAR00088 & 1 & 0,934997 \\
\hline VAR00039 & 1 & 0,961488 & VAR00089 & 1 & 0,943825 \\
\hline VAR00040 & 1 & 0,979191 & VAR00090 & 1 & 0,873141 \\
\hline VAR00041 & 1 & 0,993951 & VAR00091 & 1 & 0,992619 \\
\hline VAR00042 & 1 & 0,901892 & VAR00092 & 1 & 0,984788 \\
\hline VAR00043 & 1 & 0,986053 & VAR00093 & 1 & 0,979807 \\
\hline VAR00044 & 1 & 0,965882 & VAR00094 & 1 & 0,961304 \\
\hline VAR00045 & 1 & 0,902844 & VAR00095 & 1 & 0,838504 \\
\hline VAR00046 & 1 & 0,888266 & VAR00096 & 1 & 0,918843 \\
\hline VAR00047 & 1 & 0,9923 & VAR00097 & 1 & 0,972834 \\
\hline VAR00048 & 1 & 0,971061 & VAR00098 & 1 & 0,996549 \\
\hline Extraction Meth & od: Princip & al Compon & nent Analys & & \\
\hline
\end{tabular}




\begin{tabular}{|c|c|c|c|c|c|c|}
\hline Communalities & & DIV & & VAR00049 & 1 & 0,936339 \\
\hline & Initial & & Extraction & VAR00050 & 1 & 0,98289 \\
\hline VAR00001 & & 1 & 0,986568 & VAR00051 & 1 & 0,941422 \\
\hline VAR00002 & & 1 & 0,970372 & VAR00052 & 1 & 0,988316 \\
\hline VAR00003 & & 1 & 0,991126 & VAR00053 & 1 & 0,989931 \\
\hline VAR00004 & & 1 & 0,982179 & VAR00054 & 1 & 0,95208 \\
\hline VAR00005 & & 1 & 0,8706 & VAR00055 & 1 & 0,949422 \\
\hline VAR00006 & & 1 & 0,925847 & VAR00056 & 1 & 0,984049 \\
\hline VAR00007 & & 1 & 0,992977 & VAR00057 & 1 & 0,969164 \\
\hline VAR00008 & & 1 & 0,988372 & VAR00058 & 1 & 0,944655 \\
\hline VAR00009 & & 1 & 0,990112 & VAR00059 & 1 & 0,99011 \\
\hline VAR00010 & & 1 & 0,870256 & VAR00060 & 1 & 0,967266 \\
\hline VAR00011 & & 1 & 0,977106 & VAR00061 & 1 & 0,839622 \\
\hline VAR00012 & & 1 & 0,944557 & VAR00062 & 1 & 0,938326 \\
\hline VAR00013 & & 1 & 0,833245 & VAR00063 & 1 & 0,991711 \\
\hline VAR00014 & & 1 & 0,913349 & VAR00064 & 1 & 0,939165 \\
\hline VAR00015 & & 1 & 0,985715 & VAR00065 & 1 & 0,991524 \\
\hline VAR00016 & & 1 & 0,941882 & VAR00066 & 1 & 0,949284 \\
\hline VAR00017 & & 1 & 0,949321 & VAR00067 & 1 & 0,993631 \\
\hline VAR00018 & & 1 & 0,978677 & VAR00068 & 1 & 0,936808 \\
\hline VAR00019 & & 1 & 0,855966 & VAR00069 & 1 & 0,987293 \\
\hline VAR00020 & & 1 & 0,944937 & VAR00070 & 1 & 0,990035 \\
\hline VAR00021 & & 1 & 0,985615 & VAR00071 & 1 & 0,997204 \\
\hline VAR00022 & & 1 & 0,879961 & VAR00072 & 1 & 0,973005 \\
\hline VAR00023 & & 1 & 0,996186 & VAR00073 & 1 & 0,965931 \\
\hline VAR00024 & & 1 & 0,905713 & VAR00074 & 1 & 0,94116 \\
\hline VAR00025 & & 1 & 0,964957 & VAR00075 & 1 & 0,978745 \\
\hline VAR00026 & & 1 & 0,929256 & VAR00076 & 1 & 0,886024 \\
\hline VAR00027 & & 1 & 0,856292 & VAR00077 & 1 & 0,958832 \\
\hline VAR00028 & & 1 & 0,949655 & VAR00078 & 1 & 0,991023 \\
\hline VAR00029 & & 1 & 0,963236 & VAR00079 & 1 & 0,87827 \\
\hline VAR00030 & & 1 & 0,992126 & VAR00080 & 1 & 0,912663 \\
\hline VAR00031 & & 1 & 0,970527 & VAR00081 & 1 & 0,972793 \\
\hline VAR00032 & & 1 & 0,974701 & VAR00082 & 1 & 0,902077 \\
\hline VAR00033 & & 1 & 0,78381 & VAR00083 & 1 & 0,943692 \\
\hline VAR00034 & & 1 & 0,946394 & VAR00084 & 1 & 0,985012 \\
\hline VAR00035 & & 1 & 0,977716 & VAR00085 & 1 & 0,928875 \\
\hline VAR00036 & & 1 & 0,967272 & VAR00086 & 1 & 0,932179 \\
\hline VAR00037 & & 1 & 0,970839 & VAR00087 & 1 & 0,987357 \\
\hline VAR00038 & & 1 & 0,923957 & VAR00088 & 1 & 0,936991 \\
\hline VAR00039 & & 1 & 0,956761 & VAR00089 & 1 & 0,990721 \\
\hline VAR00040 & & 1 & 0,990798 & VAR00090 & 1 & 0,987565 \\
\hline VAR00041 & & 1 & 0,981623 & VAR00091 & 1 & 0,987602 \\
\hline VAR00042 & & 1 & 0,893901 & VAR00092 & 1 & 0,988612 \\
\hline VAR00043 & & 1 & 0,983274 & VAR00093 & 1 & 0,991664 \\
\hline VAR00044 & & 1 & 0,749835 & VAR00094 & 1 & 0,989035 \\
\hline VAR00045 & & 1 & 0,811984 & VAR00095 & 1 & 0,992152 \\
\hline VAR00046 & & 1 & 0,996019 & VAR00096 & 1 & 0,915078 \\
\hline VAR00047 & & 1 & 0,931091 & VAR00097 & 1 & 0,98583 \\
\hline VAR00048 & & 1 & 0,988424 & VAR00098 & 1 & 0,978002 \\
\hline
\end{tabular}




\begin{tabular}{|c|c|c|c|c|c|}
\hline Communalities & LAIR & RAT & VAR00049 & 1 & 0,958804 \\
\hline & Initial & Extraction & VAR00050 & 1 & 0,998454 \\
\hline VAR00001 & 1 & 0,941411 & VAR00051 & 1 & 0,978144 \\
\hline VAR00002 & 1 & 0,936046 & VAR00052 & 1 & 0,981043 \\
\hline VAR00003 & 1 & 0,953241 & VAR00053 & 1 & 0,970216 \\
\hline VAR00004 & 1 & 0,843212 & VAR00054 & 1 & 0,980261 \\
\hline VAR00005 & 1 & 0,968425 & VAR00055 & 1 & 0,944334 \\
\hline VAR00006 & 1 & 0,980558 & VAR00056 & 1 & 0,919803 \\
\hline VAR00007 & 1 & 0,926434 & VAR00057 & 1 & 0,975844 \\
\hline VAR00008 & 1 & 0,952943 & VAR00058 & 1 & 0,948233 \\
\hline VAR00009 & 1 & 0,957471 & VAR00059 & 1 & 0,99769 \\
\hline VAR00010 & 1 & 0,896605 & VAR00060 & 1 & 0,996017 \\
\hline VAR00011 & 1 & 0,993489 & VAR00061 & 1 & 0,987582 \\
\hline VAR00012 & 1 & 0,896242 & VAR00062 & 1 & 0,986951 \\
\hline VAR00013 & 1 & 0,971949 & VAR00063 & 1 & 0,997189 \\
\hline VAR00014 & 1 & 0,935831 & VAR00064 & 1 & 0,980629 \\
\hline VAR00015 & 1 & 0,847284 & VAR00065 & 1 & 0,893709 \\
\hline VAR00016 & 1 & 0,99303 & VAR00066 & 1 & 0,995123 \\
\hline VAR00017 & 1 & 0,945991 & VAR00067 & 1 & 0,983117 \\
\hline VAR00018 & 1 & 0,930399 & VAR00068 & 1 & 0,914104 \\
\hline VAR00019 & 1 & 0,914196 & VAR00069 & 1 & 0,9947 \\
\hline VAR00020 & 1 & 0,941523 & VAR00070 & 1 & 0,942325 \\
\hline VAR00021 & 1 & 0,946636 & VAR00071 & 1 & 0,947589 \\
\hline VAR00022 & 1 & 0,945083 & VAR00072 & 1 & 0,814498 \\
\hline VAR00023 & 1 & 0,98709 & VAR00073 & 1 & 0,817749 \\
\hline VAR00024 & 1 & 0,835373 & VAR00074 & 1 & 0,985563 \\
\hline VAR00025 & 1 & 0,877614 & VAR00075 & 1 & 0,99282 \\
\hline VAR00026 & 1 & 0,989447 & VAR00076 & 1 & 0,9021 \\
\hline VAR00027 & 1 & 0,996219 & VAR00077 & 1 & 0,938728 \\
\hline VAR00028 & 1 & 0,977615 & VAR00078 & 1 & 0,988463 \\
\hline VAR00029 & 1 & 0,991325 & VAR00079 & 1 & 0,853459 \\
\hline VAR00030 & 1 & 0,866133 & VAR00080 & 1 & 0,989817 \\
\hline VAR00031 & 1 & 0,991063 & VAR00081 & 1 & 0,987785 \\
\hline VAR00032 & 1 & 0,927946 & VAR00082 & 1 & 0,996866 \\
\hline VAR00033 & 1 & 0,931165 & VAR00083 & 1 & 0,985496 \\
\hline VAR00034 & 1 & 0,832703 & VAR00084 & 1 & 0,978734 \\
\hline VAR00035 & 1 & 0,928176 & VAR00085 & 1 & 0,983648 \\
\hline VAR00036 & 1 & 0,989591 & VAR00086 & 1 & 0,998102 \\
\hline VAR00037 & 1 & 0,993611 & VAR00087 & 1 & 0,998102 \\
\hline VAR00038 & 1 & 0,848578 & VAR00088 & 1 & 0,994212 \\
\hline VAR00039 & 1 & 0,981087 & VAR00089 & 1 & 0,845833 \\
\hline VAR00040 & 1 & 0,968646 & VAR00090 & 1 & 0,997961 \\
\hline VAR00041 & 1 & 0,997939 & VAR00091 & 1 & 0,979492 \\
\hline VAR00042 & 1 & 0,99723 & VAR00092 & 1 & 0,99664 \\
\hline VAR00043 & 1 & 0,995301 & VAR00093 & 1 & 0,998151 \\
\hline VAR00044 & 1 & 0,997879 & VAR00094 & 1 & 0,997622 \\
\hline VAR00045 & 1 & 0,903216 & VAR00095 & 1 & 0,988244 \\
\hline VAR00046 & 1 & 0,966428 & VAR00096 & 1 & 0,996654 \\
\hline VAR00047 & 1 & 0,955989 & VAR00097 & 1 & 0,993628 \\
\hline VAR00048 & 1 & 0,962484 & VAR00098 & 1 & 0,995768 \\
\hline Extraction M & : Principa & al Compon & ent Analys & & \\
\hline
\end{tabular}




\begin{tabular}{|c|c|c|c|c|c|}
\hline Communalitie & GIRC & $\mathrm{OPL}$ & VAR00049 & 1 & 0,979765 \\
\hline & Initial & Extraction & VAR00050 & 1 & 0,961587 \\
\hline VAR00001 & 1 & 0,911462 & VAR00051 & 1 & 0,938316 \\
\hline VAR00002 & 1 & 0,955926 & VAR00052 & 1 & 0,981354 \\
\hline VAR00003 & 1 & 0,972428 & VAR00053 & 1 & 0,947132 \\
\hline VAR00004 & 1 & 0,995726 & VAR00054 & 1 & 0,987218 \\
\hline VAR00005 & 1 & 0,99521 & VAR00055 & 1 & 0,945652 \\
\hline VAR00006 & 1 & 0,943027 & VAR00056 & 1 & 0,924306 \\
\hline VAR00007 & 1 & 0,882078 & VAR00057 & 1 & 0,926494 \\
\hline VAR00008 & 1 & 0,858289 & VAR00058 & 1 & 0,87976 \\
\hline VAR00009 & 1 & 0,876102 & VAR00059 & 1 & 0,994221 \\
\hline VAR00010 & 1 & 0,956182 & VAR00060 & 1 & 0,988621 \\
\hline VAR00011 & 1 & 0,919917 & VAR00061 & 1 & 0,993208 \\
\hline VAR00012 & 1 & 0,994501 & VAR00062 & 1 & 0,957607 \\
\hline VAR00013 & 1 & 0,991897 & VAR00063 & 1 & 0,720341 \\
\hline VAR00014 & 1 & 0,992569 & VAR00064 & 1 & 0,997186 \\
\hline VAR00015 & 1 & 0,958786 & VAR00065 & 1 & 0,96086 \\
\hline VAR00016 & 1 & 0,922199 & VAR00066 & 1 & 0,994035 \\
\hline VAR00017 & 1 & 0,988322 & VAR00067 & 1 & 0,882316 \\
\hline VAR00018 & 1 & 0,754212 & VAR00068 & 1 & 0,98881 \\
\hline VAR00019 & 1 & 0,947718 & VAR00069 & 1 & 0,941992 \\
\hline VAR00020 & 1 & 0,988185 & VAR00070 & 1 & 0,996575 \\
\hline VAR00021 & 1 & 0,987455 & VAR00071 & 1 & 0,99282 \\
\hline VAR00022 & 1 & 0,964369 & VAR00072 & 1 & 0,940418 \\
\hline VAR00023 & 1 & 0,49985 & VAR00073 & 1 & 0,880547 \\
\hline VAR00024 & 1 & 0,992601 & VAR00074 & 1 & 0,918201 \\
\hline VAR00025 & 1 & 0,966212 & VAR00075 & 1 & 0,984309 \\
\hline VAR00026 & 1 & 0,992992 & VAR00076 & 1 & 0,761275 \\
\hline VAR00027 & 1 & 0,997095 & VAR00077 & 1 & 0,964817 \\
\hline VAR00028 & 1 & 0,964245 & VAR00078 & 1 & 0,980691 \\
\hline VAR00029 & 1 & 0,986722 & VAR00079 & 1 & 0,950221 \\
\hline VAR00030 & 1 & 0,758005 & VAR00080 & 1 & 0,991683 \\
\hline VAR00031 & 1 & 0,992251 & VAR00081 & 1 & 0,97608 \\
\hline VAR00032 & 1 & 0,93684 & VAR00082 & 1 & 0,859225 \\
\hline VAR00033 & 1 & 0,874655 & VAR00083 & 1 & 0,987924 \\
\hline VAR00034 & 1 & 0,975648 & VAR00084 & 1 & 0,993029 \\
\hline VAR00035 & 1 & 0,894387 & VAR00085 & 1 & 0,86749 \\
\hline VAR00036 & 1 & 0,922109 & VAR00086 & 1 & 0,993604 \\
\hline VAR00037 & 1 & 0,993301 & VAR00087 & 1 & 0,907884 \\
\hline VAR00038 & 1 & 0,997779 & VAR00088 & 1 & 0,881984 \\
\hline VAR00039 & 1 & 0,995291 & VAR00089 & 1 & 0,865084 \\
\hline VAR00040 & 1 & 0,966005 & VAR00090 & 1 & 0,981628 \\
\hline VAR00041 & 1 & 0,996609 & VAR00091 & 1 & 0,997104 \\
\hline VAR00042 & 1 & 0,997148 & VAR00092 & 1 & 0,984976 \\
\hline VAR00043 & 1 & 0,983591 & VAR00093 & 1 & 0,998353 \\
\hline VAR00044 & 1 & 0,859441 & VAR00094 & 1 & 0,89191 \\
\hline VAR00045 & 1 & 0,920046 & VAR00095 & 1 & 0,884664 \\
\hline VAR00046 & 1 & 0,950257 & VAR00096 & 1 & 0,994646 \\
\hline VAR00047 & 1 & 0,900677 & VAR00097 & 1 & 0,842581 \\
\hline VAR00048 & 1 & 0,607665 & VAR00098 & 1 & 0,994912 \\
\hline \multicolumn{6}{|c|}{ Extraction Method: Principal Component Analy } \\
\hline
\end{tabular}




\begin{tabular}{|c|c|c|c|c|c|}
\hline Communa & REC & CAT & VAR00049 & 1 & 0,98097 \\
\hline Initial & & Extraction & VAR00050 & 1 & 0,912261 \\
\hline VAR00001 & 1 & 0,998769 & VAR00051 & 1 & 0,993299 \\
\hline VAR00002 & 1 & 0,939415 & VAR00052 & 1 & 0,979993 \\
\hline VAR00003 & 1 & 0,952728 & VAR00053 & 1 & 0,989974 \\
\hline VAR00004 & 1 & 0,881486 & VAR00054 & 1 & 0,987257 \\
\hline VAR00005 & 1 & 0,993765 & VAR00055 & 1 & 0,985374 \\
\hline VAR00006 & 1 & 0,997288 & VAR00056 & 1 & 0,992017 \\
\hline VAR00007 & 1 & 0,997548 & VAR00057 & 1 & 0,961726 \\
\hline VAR00008 & 1 & 0,862269 & VAR00058 & 1 & 0,974722 \\
\hline VAR00009 & 1 & 0,997838 & VAR00059 & 1 & 0,967188 \\
\hline VAR00010 & 1 & 0,984794 & VAR00060 & 1 & 0,998748 \\
\hline VAR00011 & 1 & 0,983582 & VAR00061 & 1 & 0,99661 \\
\hline VAR00012 & 1 & 0,992143 & VAR00062 & 1 & 0,996558 \\
\hline VAR00013 & 1 & 0,987198 & VAR00063 & 1 & 0,993012 \\
\hline VAR00014 & 1 & 0,993616 & VAR00064 & 1 & 0,990873 \\
\hline VAR00015 & 1 & 0,996739 & VAR00065 & 1 & 0,985862 \\
\hline VAR00016 & 1 & 0,996507 & VAR00066 & 1 & 0,979029 \\
\hline VAR00017 & 1 & 0,998065 & VAR00067 & 1 & 0,998965 \\
\hline VAR00018 & 1 & 0,996278 & VAR00068 & 1 & 0,921525 \\
\hline VAR00019 & 1 & 0,996339 & VAR00069 & 1 & 0,994705 \\
\hline VAR00020 & 1 & 0,997933 & VAR00070 & 1 & 0,981482 \\
\hline VAR00021 & 1 & 0,995146 & VAR00071 & 1 & 0,991509 \\
\hline VAR00022 & 1 & 0,987226 & VAR00072 & 1 & 0,996737 \\
\hline VAR00023 & 1 & 0,99071 & VAR00073 & 1 & 0,960061 \\
\hline VAR00024 & 1 & 0,997101 & VAR00074 & 1 & 0,958283 \\
\hline VAR00025 & 1 & 0,993463 & VAR00075 & 1 & 0,987024 \\
\hline VAR00026 & 1 & 0,980684 & VAR00076 & 1 & 0,995747 \\
\hline VAR00027 & 1 & 0,998427 & VAR00077 & 1 & 0,978767 \\
\hline VAR00028 & 1 & 0,978779 & VAR00078 & 1 & 0,799565 \\
\hline VAR00029 & 1 & 0,97242 & VAR00079 & 1 & 0,994682 \\
\hline VAR00030 & 1 & 0,982113 & VAR00080 & 1 & 0,992599 \\
\hline VAR00031 & 1 & 0,996075 & VAR00081 & 1 & 0,999333 \\
\hline VAR00032 & 1 & 0,966755 & VAR00082 & 1 & 0,990833 \\
\hline VAR00033 & 1 & 0,97273 & VAR00083 & 1 & 0,9959 \\
\hline VAR00034 & 1 & 0,995847 & VAR00084 & 1 & 0,980697 \\
\hline VAR00035 & 1 & 0,993338 & VAR00085 & 1 & 0,983113 \\
\hline VAR00036 & 1 & 0,996667 & VAR00086 & 1 & 0,985962 \\
\hline VAR00037 & 1 & 0,991278 & VAR00087 & 1 & 0,984091 \\
\hline VAR00038 & 1 & 0,981634 & VAR00088 & 1 & 0,989138 \\
\hline VAR00039 & 1 & 0,946199 & VAR00089 & 1 & 0,94404 \\
\hline VAR00040 & 1 & 0,997054 & VAR00090 & 1 & 0,995406 \\
\hline VAR00041 & 1 & 0,972248 & VAR00091 & 1 & 0,908877 \\
\hline VAR00042 & 1 & 0,823676 & VAR00092 & 1 & 0,980608 \\
\hline VAR00043 & 1 & 0,972537 & VAR00093 & 1 & 0,980069 \\
\hline VAR00044 & 1 & 0,992126 & VAR00094 & 1 & 0,989378 \\
\hline VAR00045 & 1 & 0,977183 & VAR00095 & 1 & 0,997522 \\
\hline VAR00046 & 1 & 0,997606 & VAR00096 & 1 & 0,985596 \\
\hline VAR00047 & 1 & 0,993908 & VAR00097 & 1 & 0,997761 \\
\hline VAR00048 & 1 & 0,987951 & VAR00098 & 1 & 0,99602 \\
\hline \multicolumn{6}{|c|}{ Extraction Method: Principal Component Ana } \\
\hline
\end{tabular}




\begin{tabular}{|c|c|c|c|c|c|}
\hline Communaliti & GA & $A F$ & VAR00049 & 1 & 0,949696 \\
\hline & Initial & Extraction & VAR00050 & 1 & 0,948419 \\
\hline VAR00001 & 1 & 0,997353 & VAR00051 & 1 & 0,950288 \\
\hline VAR00002 & 1 & 0,975204 & VAR00052 & 1 & 0,989981 \\
\hline VAR00003 & 1 & 0,986104 & VAR00053 & 1 & 0,945772 \\
\hline VAR00004 & 1 & 0,957748 & VAR00054 & 1 & 0,963458 \\
\hline VAR00005 & 1 & 0,993894 & VAR00055 & 1 & 0,749686 \\
\hline VAR00006 & 1 & 0,991685 & VAR00056 & 1 & 0,9686 \\
\hline VAR00007 & 1 & 0,920718 & VAR00057 & 1 & 0,96059 \\
\hline VAR00008 & 1 & 0,935752 & VAR00058 & 1 & 0,997263 \\
\hline VAR00009 & 1 & 0,836255 & VAR00059 & 1 & 0,968902 \\
\hline VAR00010 & 1 & 0,952019 & VAR00060 & 1 & 0,990339 \\
\hline VAR00011 & 1 & 0,931338 & VAR00061 & 1 & 0,857461 \\
\hline VAR00012 & 1 & 0,988 & VAR00062 & 1 & 0,991071 \\
\hline VAR00013 & 1 & 0,900262 & VAR00063 & 1 & 0,896879 \\
\hline VAR00014 & 1 & 0,975714 & VAR00064 & 1 & 0,98869 \\
\hline VAR00015 & 1 & 0,935393 & VAR00065 & 1 & 0,801662 \\
\hline VAR00016 & 1 & 0,59444 & VAR00066 & 1 & 0,878491 \\
\hline VAR00017 & 1 & 0,862463 & VAR00067 & 1 & 0,913889 \\
\hline VAR00018 & 1 & 0,971517 & VAR00068 & 1 & 0,995241 \\
\hline VAR00019 & 1 & 0,953914 & VAR00069 & 1 & 0,903792 \\
\hline VAR00020 & 1 & 0,844238 & VAR00070 & 1 & 0,914338 \\
\hline VAR00021 & 1 & 0,918603 & VAR00071 & 1 & 0,940086 \\
\hline VAR00022 & 1 & 0,942276 & VAR00072 & 1 & 0,946565 \\
\hline VAR00023 & 1 & 0,996705 & VAR00073 & 1 & 0,94356 \\
\hline VAR00024 & 1 & 0,960184 & VAR00074 & 1 & 0,859679 \\
\hline VAR00025 & 1 & 0,993138 & VAR00075 & 1 & 0,967872 \\
\hline VAR00026 & 1 & 0,791711 & VAR00076 & 1 & 0,911353 \\
\hline VAR00027 & 1 & 0,880313 & VAR00077 & 1 & 0,996136 \\
\hline VAR00028 & 1 & 0,968932 & VAR00078 & 1 & 0,988331 \\
\hline VAR00029 & 1 & 0,947744 & VAR00079 & 1 & 0,85611 \\
\hline VAR00030 & 1 & 0,878931 & VAR00080 & 1 & 0,856099 \\
\hline VAR00031 & 1 & 0,81997 & VAR00081 & 1 & 0,972651 \\
\hline VAR00032 & 1 & 0,995021 & VAR00082 & 1 & 0,934995 \\
\hline VAR00033 & 1 & 0,891358 & VAR00083 & 1 & 0,98487 \\
\hline VAR00034 & 1 & 0,797677 & VAR00084 & 1 & 0,828911 \\
\hline VAR00035 & 1 & 0,983746 & VAR00085 & 1 & 0,94195 \\
\hline VAR00036 & 1 & 0,993652 & VAR00086 & 1 & 0,880863 \\
\hline VAR00037 & 1 & 0,997311 & VAR00087 & 1 & 0,955114 \\
\hline VAR00038 & 1 & 0,970644 & VAR00088 & 1 & 0,871266 \\
\hline VAR00039 & 1 & 0,970514 & VAR00089 & 1 & 0,894232 \\
\hline VAR00040 & 1 & 0,735568 & VAR00090 & 1 & 0,960283 \\
\hline VAR00041 & 1 & 0,980416 & VAR00091 & 1 & 0,907766 \\
\hline VAR00042 & 1 & 0,951049 & VAR00092 & 1 & 0,849631 \\
\hline VAR00043 & 1 & 0,737405 & VAR00093 & 1 & 0,992983 \\
\hline VAR00044 & 1 & 0,920251 & VAR00094 & 1 & 0,990499 \\
\hline VAR00045 & 1 & 0,853495 & VAR00095 & 1 & 0,941706 \\
\hline VAR00046 & 1 & 0,997704 & VAR00096 & 1 & 0,929012 \\
\hline VAR00047 & 1 & 0,87307 & VAR00097 & 1 & 0,974565 \\
\hline VAR00048 & 1 & 0,973746 & VAR00098 & 1 & 0,994413 \\
\hline
\end{tabular}

